University of Louisville

ThinkIR: The University of Louisville's Institutional Repository

1946

\title{
The relationship of seventeenth century and twentieth century metaphysical poetry.
}

Joseph E. Duncan 1921-1991

University of Louisville

Follow this and additional works at: https://ir.library.louisville.edu/etd

Part of the Literature in English, British Isles Commons

\section{Recommended Citation}

Duncan, Joseph E. 1921-1991, "The relationship of seventeenth century and twentieth century metaphysical poetry." (1946). Electronic Theses and Dissertations. Paper 1922.

https://doi.org/10.18297/etd/1922

This Master's Thesis is brought to you for free and open access by ThinkIR: The University of Louisville's Institutional Repository. It has been accepted for inclusion in Electronic Theses and Dissertations by an authorized administrator of ThinkIR: The University of Louisville's Institutional Repository. This title appears here courtesy of the author, who has retained all other copyrights. For more information, please contact thinkir@louisville.edu. 


\section{UN TVERSITY OF LOUISVILLE}

THE RELATIONSHIP OF SEVEN TEENTH CEN TURY AND TWEN TIETH CEN TURY METAPHYSICAL

POETRY

A DISSERTATION

Submitted to the Faculty

Of the Graduate School of the University of Louisville

In Partial Fulfillmont of the

Requirements for the Degreo

Of Master of Arts

Department of English

By

Joseph $E:$ Dunoan

1946

71.75 
NAME OF STUDENT: Joseph E. Duncan

TITLE OF THESIS: THE RELATIONSHIF OF SEVEN TEENTH CENTURY AND TWEN TIETH CEN TURY METAPEYSICAL POE TRY

APRROVED BY READING COHII TIEE COMPOSED OF THE FOLIOWIIG MEMBERS :

Ernest C. Hassold

Richard M. Kain

Justus Bier

NAME OF DIRECTOR:

Ernest C. Hassold

DA TE: fone $3,19+6$ 
TABLE OF CONTENTS

Chapter I

Introduction

1

Chapter II

Poetic Progression

29

Chapter III

Metaphor

58

Chapter IV

The Troatment of Experience

87

Chapter V

Social Viewpoints

131

Chapter VI

Conclusions

Bibliography

180 
CHAPTER I

IN TRODUC TION 


\section{CHAPTER I: INTRODUCTION}

The importance of seventeenth century and modern motaphysical poetry in the English literary tradition is very seldom disputod by the twentieth century oritic and scholar. This poetic style, which was generally ignored wi thout study fifty years ago, is today a center of attention in the world of letters. The enormous volume of criticism and scholarship devoted to both early and modern metaphysical verse testifies to its popularity with modern students and critics, while many of the best American and British poets are writing tocay in an essentially motaphysical tradition. In fact in both the seventerth and twontioth centuries almost the whole field of poetry has se日med to reflect motaphysical practice in some moasure.

The tremendous impect of the metaphysical style upon the modern mind is suggested in the best arailable bibliographicel guides to this field, Studies in Metaphysical Poetry, by Theodore Spencer and Mark Van Doren. In the introduction to this work Professor spencer points out that a list of titles of works dealing with the entire nineteenth century would be only half as long as a similar list of works treating the seventeonth century metaphysiogl poets alone.

This abundance of material, he continues, reflects "not merely an antiquarian curiosity, but a real excitement about a type of poetry whibh recent poets have much admired, and which was the expression of a generation faced by many problems similar to our own." I Indeed this muchdiscussed similerity betweon the seventeenth and twentieth centuries is at

1. Spencer, Theodore; Van Doren, Mark, Studies in Metaphysical Pootry, P.3 
the orux of the problem of the wide attention given metephysical verse today.

It is very difficult to say precisely when this new interest began, but a glance through the poetic works of Emily Dickirson will indicate that she was thoroughly familiar with the seventeenth century metaphysical poots about three score yoars ago, and found their thought and techmique very congenial to her ow vorse writing and psyohological makeup. In Eland, the lively intellectual worhplay of Gerald Manley Hopkins and the complexity and irony in the verse of George Meredith also suggests a renascence of the metaphysical way of thinking. Probably the first landmark in the morement was the publication in 1912 of Herbert Grierson's definitive edition of the poetry of John Donne, the most famous of the seventeonth century metaphysicals. Examining the place of Donne and the seventeenth metaphysic Is in the world literay tradition, Grierson set a model for scholarship in his exhaustive efforts to arrive at the correct poetic texts and to determine the dates and authenticity of the poems usually attributed to Donne. Since that time popular editions of the works of Abraham Cowley, Andrew Marve11, George Herbert, Henry Vaughan and others have beon publishod, and metaphysicel verse--early and modern-hes remained in high favor. A growing interest was also indicated by tho appearance of carefully edited editions of such comparatively minor poots as John Cleveland and Henry King.

Not to mention the appearance of an influential group of modern motaphysical poets, the enthusiastic studies of many contemporary critics, a number of them metaphysicel poets in their own right, have probably done much to stimulate an interest in metaphysical verse. A group of essays written by T.S. Eliot in the 1920's for instance, is. 
probably among the most important of the interpretative and critical works dealing with the seventeon century motaphysical poets and their general cultural environment, and certainly fliot's thesis concorning the "unified sensibility" of the seventeenth century man as opposed to the "divided sensibility" of the average nineteenth and twentioth contury man has come to be aocepted almost as a truism.

Another indication of the widespread twontieth century affinity for the metaphysical spirit is seen in the publicition in 1945 of "Critical Remarks on the Motaphysical Poets," which contains twelve line drawings by Kurt Roesch. The new accent on metaphysical poetry in the United States has come in a large measure thropgh the efforts of Southerners. John Crowe Rensom and Allen Tate have created a now interest in this kind of verse through both their own poetry and their critical essays. Probably the boldest and most complete attempt, however, to relate seventeenth and twentieth century verse is faund in Cleanth Brooks Modern Poetry end the Tradition. Explaining that there is a mixture of wit, irony and "high seriousness" in the metaphysical verse of both these periods such as is seldom found in romantic and classic poetry, Brooks emphasizes that "tho significant relotionship betwe the modernist poets and the seventeenth century poets of wit lies here--in thitr common conception of the use of metaphor....The significant relationship is indicated by tre fact that the motaphysical poets and the modernists stand opposed to both the neo-clessic and Romantic poets on the issue of metaphor." 1

As Eliot has remarked in his essay on "The Metaphysical Poots," it is exceodingly difficult to determine a clear-out line of demarcation between "motaphysical poets" and a number of other poets writing at the same timo.

1. Brooks, Cleanth, Modern Poetry and the Tradition, p. 11. 
The distinction perhaps rests in the degree to which various poets mey employ a metaphysical techique. Past scholarship, however, has tended to single out a group of seventeenth century foets who have been labelled and aocepted as the "metaphysical poets." There has been a little less scholerly agreement concerning the twentieth century metaphysical poets.

Motephysical elements may be foumd in Italian Reneissance verse end in the work of many English poets from Sir Thomas Wyatt and the Earl of Surrey until the last quarter of the seventeenth century. The metaphysical style had itis origin in secular verse, but in the seventeenth century it beceme modium for a group of secular poets and a group of religious poets, both of which apperently found their greatest inspiration in the verse of Donne. It should be stressed, however, that metaphysical expression is not necessarily either secular or religious, but a way of thinking and writing probably equally suited to both types of verse. The mystical tendencies of some of these poets became merged with the metaphysical technique to produce on many occesions some of the finest poetry in our language, but this mysticism should not be considered as a characteristic attribute of metaphysical poetry. As the seventeonth century proceeded, the work of such poots as Marvell and Abraham Cowloy tended to merge with the incipient neo-classic tradition, while such metaphysical poets as Henry Vaughan and Thomas Traherne anticipated Wordsworthian romanticism in their thought and style.

Despite the interest today in this religious motaphysical poetry, particilarly since the publication in 1936 of Helen White's The Motaphysicel Poets, A Study in Religious Experience, the twentieth century metephysicels are much more closely related to the secular group. 
Aligned with the religious group were some of the best known seventeenth century metaphysicel poets : Jom Dorne (1573-163I), George Herbert (15931633), Richard Crashar (1612-1649), Henry Vaughan (1622-1695), and Thomas Traherne (1636-1674), but the metaphysical elements in the verse of both Vaughan and Traherne, especially that of the latter, tend to become secondary to the mysticism. The secular metaphysical tradition is represented by Sir Walter Raleigh (1552-1618), in several of his best poems; William Shakespearo (1564-1616), particularly in a number of his sonnots, Donne, Edwerd, Lord Herbert of Cherbury (1583-1€48), who was George Herbert's younger brother; Henry King (1592-1669), John Cleveland, (16131658), Abraham Cowley (1618-1667), Andrew Marvell (1621-1678), and a number of other poets in whose verse the metaphysicel elements are less conspicuaus or less skillfully handled.

The twontieth century metaphysicel tradition is almost entirely secular and literary. The seventeenth century poets were usually men . of action or men of God before they were poets, but the twentieth century metaphysical poets are on the whole exclusively poots and critics. Although Elict's religionism has played an incressingly important pert in his work, his verse has proved to be the most metaphysical when it was the least religious. Among British and American poots the chief motaphysicals are William Butler Yeats (1865-1938), Elinor Wylio (1885-1928), T. S. Eliot (1888- ), John Crowe Ransom (188- ), Allon Tate (1899-), Robert Fenn Warren (1905-), and Wystan Bugh Auden (1907- )

To examine this relationship between the poetry of the seventeenth and twentieth centuries it is of course necessary to undersiand what are the distincitve characteristics of motaphysical poetry, and more specifically what are the distinctive characteristics of the seventeanth and 
twentieth century varieties. I shall attempt to point out and illustrate the chief similarities and dissimilarities in the metanysical Jerse of both periods, and to show that modern metaphysical pootry contains elements of seventeenth century metaphysical and nineteenth century romantic technique as well as distinctly modern characteristics. in this chapter I hope to clarify and point up my findings in the examination of a series of four comparable poems indicating the relation of seventeenth and twentieth century metaphysical verse to other literary styles. In examining this series of poems and in studying the characteristic similarities and dissimilarities in seventeenth and twentieth century metaphysical poetry, I shall consider three main aspects of the foetry: organization and methods of progression within the poem (Chapter II) and the use of metaphor and other structural devices (Chapter III); the interpretation of human experience, with special. attention to the wit, irony and general complexity tipical of metaphysical poetry (Chapter IV), and the poet's point of view--his attitudes toward himself and his social and intellectual world (Chapter V). My approach to these problems will be as objective and analytical as possiblo.

The four-poem series, dealing with love poems in which the possible death of ore of the lovers is considered, will consist of Shakespeare's 71 st sonnet, ("No longer mourn for me when I am dead"), Elizabethan; Donme's "A Valedictica: To My Name in the Window," seventeenth cantury metaphysical; Christina Rossstti's "Remembor," nineteenth century romantic, and Yeats" "Broken Dreams," twentieth century metaphysical. 
I quote the Shakespeare sonnet:

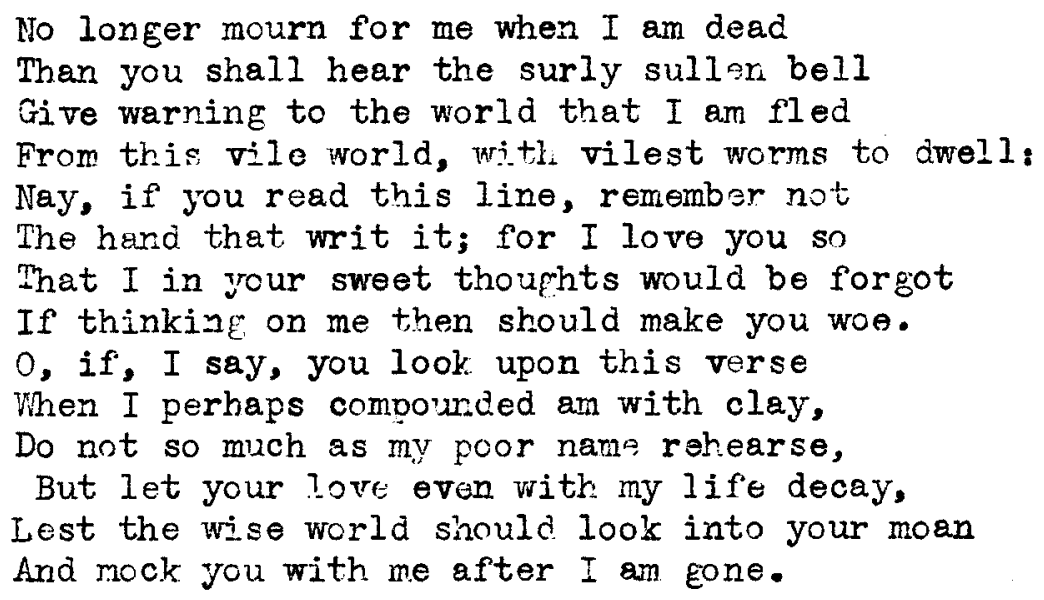

The posm is basically an elaboration of a relatively simple argument--or "structure," as Ransom. would sky. The poet asks in substance that his mistress forget him after his death because he loves her very much and does not wish to bring her grief from his passing or mockery from the "wide world." There is really no suggestion in the poem of a knotty human problem or of an actual experience. The sonnet, completely lucid and in no way involvad, progresses in a quits logical manner. The progression is simple and repetitious, however, as the three quatiains develop virtually the same idea with very little variation, while the closing couplet merely gives another reason why the mistrass siould not "moan" for her poet-Iover. This easy, smooth progressicn also depends hoavily upon the regular rhythmics and lilting quality of the verse which suggests a much closer alliance between music and poetry than is found in the more rugged, conversational rhythms of Donne.

The sornet shows principally a successful attempt to duvelopia rather conventional literary idea with a pleasing textural elaboration. 
The poem does not suggest that the poet is grappling with a real problem--as Donne often does--or seeking to express and communicate a complex hunan experienc:--as the modern metaphysicals frecuently do. The reader is delighted by the way in which the poet has developed his materie.l, rather than moved emotjonaliy by the poetic situation preserted. The poet is not concerned with defining his relationship with his mistress, but rather with his own thoughts and the literary tradition jn wizch he is writing. Ihis well balanced sonnet style, with its accentuated musical metrics and its appealing development of a contentional literary theme, in many ways typifies the Elizabethan lyric tradition.

In Donne's seventeenth century metaphysjcal style there is a new emphasis on some of these Elizabethan characteristics--the logical method of frogression, for example--and a. revolt against others, such as the lilting measires and an adherence to a literary convention. I quote Donne's "A Valediction: To My Name in the Window:" $I$

Wy name engrav'd herein, Doth contribute my firmnesse to this glasse, Which, ever since that charme, hath buene As hard, as that wich grav'd it, was; Thine eye will give it price enough, to mock The Diamonds of either rock.

\section{II}

Tis much that glasse should bee As all confessing, and through-shire as $I$, 'Tis more, that it shewes thee to thee, And cleare reflects thee to thine eye. But all such rules, loves magique can undo, Here you see mee, and I am you.

\section{III}

As no one point nor dash, Which are but accessories to this name, The showers and tempests can outwash, So shall all times find thee the some;

You this intireness better may fulfill. Who have the petterne with you still. 
IV

Or if too hard and deepe

This learning be, for a scratch'd name to teach,

It, as a given deaths head keepe,

Lovers mortalitie to preach,

or think this ragged bony name to bee

My ruinous Anatomie.

Then, as ell my soules bee,

Fmparadis'd in you, (in whom alone

I understand, and grow and see, )

The rafters of my body, bone

Being still with you, the Muscle, Sinew, and Veine,

Which tile this house, will come araine.

VI

Till my returne reparie

And recompact my scattered bory so.

As all tive vertuous powers which are

Fix'd in the starres, are said to rlow

Into such characters, as graved bee

When these siarres hare supremacie:

VII

So since this name was cut

When love and griefe their exaltation had,

No door 'gainst this names influence shut;

As much more loving, as more sed,

Twill make troe; and thou shouldst, till I returne,

Since I die daily, daily mourne.

VIII

When thy inconsiderate hand

Flings ope this casement, with mr trembling name,

To looke on one, whose wit or land

New battry to thy heart may frame,

Then thinke this name alive, and that thou thus

In it offendst my Genius.

IX

And when thy melted maid,

Corrupted by the invor's gold and pe re,

Yis letter at thy pillow 'Hath laid,

Disprted it, and tam'd thy rage,

And thou begin'st to thaw toward him, for this

hay my name step in, and hide his. 
Y.

And if this treeson coe

To an overt act, and thou write againe;

in sliperscribing, this name flow

Into thy fancy, from the pane

So, in forgetting thou remembrest right,

And unaware to mee shalt pirite.

$\mathrm{XI}$

Dut glasso, and lines must bee,

No meanes our firme substantiall Iove to keepe;

Near death inflicts this legarthie,

and this I murnure in my sleepe;

Imire this idle talke, to that I goe,

inr dying men talk often so.

In this poem, one of several raledictions, or farewells, that

Dunne wrote to bis wifo, one finds a fusion of concrete figures, intezlectual absirections, and quiet, soul-felt emotion,. This piece, unlike the Shakespeare sonnet and much romantic verse, has no simple, clear-cut argument exterding throughout the poom, but consists chiefly of a texmtural sujerstructure in which the poet seems to treat a genuine personal problem with rich doweil and sharp particularity.

The resined logic of the valediction is evicent in the rather inwived extensicr of a basic metaphor and in the fact that the poom may be wderstood on two levels. The whole poem is built around the metaphorical identification of Donne and the window in wich ris neme is engraved. Molaing his thinking amund this device, the poot, always preoccupied with death, is chiefly examining the question of how faithful his wife will remain to him after his death, kut finally discards as idle fancr this desire to maintain a death hold on his wife's affections and decides that, despite a feeling of Icreliness, he will face death alone. The emphasis, however, on a personal problem, or mental conflict, js characteristic of a great deal of seventeenth century metaphysicel 
poetm. The secona level on which the wiece mey be momstood is perhavs the ino obvious, as Lome sneales to his wife of a norldy journey-perlaps the real ocaston for the poom-mand asks her to jo ever inciful

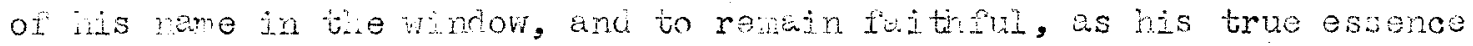
and beine is loit with her. The two lovels are beveloned a. I ost simulteneously in the first sections of the cen, but in tine closing stanzas Donne is concemed almost entirely with his feeling of impending deathe the method of propression in the voen is basioglly lowioal, wut it is a far more refined and involvod lowio than wo found ia sharespeare's 7Ist sonnet, as is seen in the two related levels of anine snd in the covelomentel, rutier than ropetitious, nutue of the lowic. Likere is also evidot in Dome's rene a arled revolt a ainst the even,

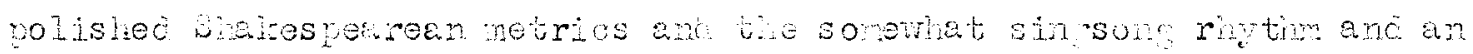
equily mareo jnterest in notanhor used as jotorial and or anizationel

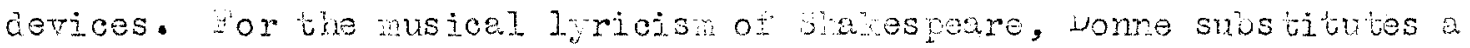
hersher, nore converstional strle, chacterized by abut rotrical breaks and a con lickted camatical construction rether than the snootin, sweet flowin sone of lizabethan rerse.

Donne's har donencenoon metaphor and similin devioes is seen

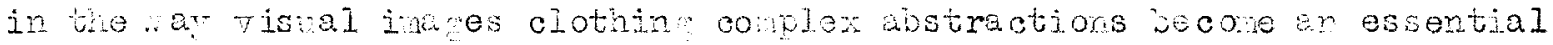
element in the poen's promession as they cabch the rader's attention ano convey lo ical subtletjos in vivid, conerete pigures. The basic metaphor, identrome the pot with tis mincow in wich is name is inscrived, is stoted incirectly in the cirst staza. he inscriotion mives to the mass his strente so tiat tio wincom, because of the inscription, may decomes Instine smool. Lu wen tis icea is cevelored paraduicaliy,

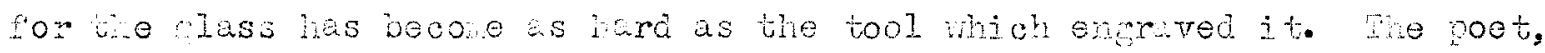

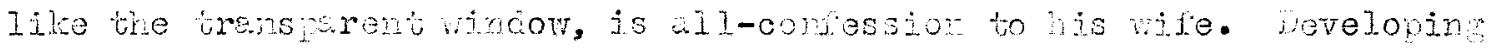


the metaphor logically, Donne refers to the reflective powers of the glass to show that "loves magique" has made the two lovers one. The miracle of love suspends the natural laws $\mathrm{kr}$ which she would see only her own inage in the glass, the poet says, so that,

Here you see mee, and I am you.

His wife shall find him always as constant as the indestructable name, for indeed she has the original pattern of both the window inscription and his love. Continuing to extend and develop the metaphor, the poet thinks that the letters are to the window like the bones to the body and elaborates upon several aspects of this idac. If identification in love is too difficult a lessor for a "scratch'd name" to keep, Donne tells his wife, regard this name as a death's head which suggests love's mortality as a skull makes us mindufl of human mortality. By a logical association of ideas characteristic of much motaphrsical verse the reference to the denth's head leads to the poet's conceptions of the "bony name" as his "ruirous Aratomie" and of his bocy as a house of which the rafters are his bones.

In stanzas $V$ and VI there is a complex of striking, concrete metaphor and finoly-spun abstractions finely illustrative of the manner in which these rather contrasting elements are fused in seventeenth century verse. The reador fints his progress through this tangled logic more pleasant and easy bacausa of the sherply visual images of the bony skeleton, the raftered house ard the erigraved window. The metaphor in which the wife is instructed to keep and cherish his bones, the rafters of his body, until he can retiurn with the muscle, sinew and reins seems apt and movjng desite the unattractiveness of the literal meaning. The illusions to the bone are alsc of course associated with the chisel gd name, emblomatic of the lovers' identification and of the 
pattern of the poet's love mentioned in stanza III. Done meens that his soul, his frame--his very essence--remeins with his wife, and he bids her recompact his scattered body from the bony name.

The logic grows somowhat more complicated as Donne uses a figure based on his astrological learning to further expand the basic metaphor of the inscribed name. The poot complains to his wife with tendermess that, since the name was cut under the ascendanoy of their love and grief, she should always be guided by its influence, and as he "dies" daily without her, she should deily mourn for his absence end perhaps for his death. There are a number of other deft touches built around the logic of the metaphor. Iranscending the laws of science, the firmly engraved name trembles at his wife's inconstancy. Again, the idea of his name flowing into her "fancy" from the pane is interesting, and provides enother indicetion of Donne's observence of the subtle workinss of the mind.

In this poom the logical propulsion of the piece and the use of motaphor are closely related; yet it is importent to exemine the metaphor for its own sake. It is clearly evident that the metaphor is of the elaborate, extended variety typical of the seventeenth century and that it serves chiefly as a logicel and pictorial device, making the subtlo relationship between the lovers more vidid and understendable. It is important to note that it is almost impossible to conceive of the poem without the metaphor.

There are of course a few smaller metaphorical effects in the poom. Illicit passion perhaps seemed to Dorne like a great fire, for the maid is "melted" and his wife "began'st to thaw." Again in stanze VIII the 
poet thinks of an unlawful lover's wit and riches as presenting a "new battery" to his wife's heart. Other metaphysical devices, such as the play on "write" and "right" in stanza X, are also found. As in most metaphysical poetry, however, the logical compliceticns of the poem are more than equeled by the mature expression of deep emotion, wit and self-inclusive satire found in the piece. A high, concentrated emotional tersion is meintained throughout the poem as the poet seaks to committ this mental conflict completely to the metaphorical framework rather than merely to suggest it through a less rigid form. Because of the metaphor the piece as sumes a greater intensity and broader scope as though another dimension had been adced to the poet's thought.

Having just spoken of love's transcendent miracle, in stanza IV Donne becomes gently satiricel in his attitude toward himiself and his wife as he remarks on "loves mortalitie." It would almost seem that he anticipated Dryden's oft-quoted objection in his"Essay on Setire" that Donne in his amorous verse "perplexes the minds of the fair sex with nice speculations of philospphy, when he should engage their hearts and entertein them with the softness of love," as he wrote:

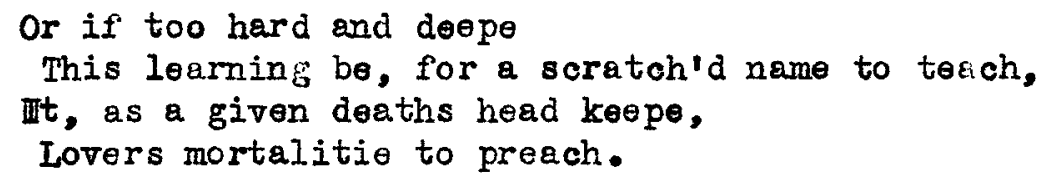

Donne here appears to be self-consciaus of the apparent incongruities inherent in the metaphysical technique, and perhaps a little amused at himself. But there is a deeper implicetion. poring love is not really "hard and deepe," but perhaps it is a lesson that the lady addressed cennot--or will not--leern. 
From this changed viewpoint the inscribed name, although a symbol of love's magic, becomes a death's head, an allusion that is the first indicetion that the poet's departure may also be his death. This touch of the macabre is typical of the metaphysicel style of Donne. Althought the closing stanzas of the poem are the most highly serious as a definite suggestion of infidelity is merged with a moving tenderness, there is at the same time a rich vein of playful wit as the poet indulges in word-play and in ar amusing fashion treats the engraved narne as a living entity.

With an allusion to death again in the concluding stanza, the poetic tension mounts:

Near death inflicts this Iothargie, And this I murmure in my sleepe; Impute this idle talke, to thet I goo, For dying mon talke often so.

The poet's mental conflict is resolved, and the central problem of the poem solved, as Donne declares that he does not wish to dominate his wife's afiections after death, although dying men often indulge in such idle talk. He will undertake his last journey alone. A feeling of self-pity is implied, but mastered by the poet.

The point of view of the poet and the tone and mood of the poem are also characteristic of the seventeenth century metaphysical style. Although the poem is addressed to a loved one in accordance with the Elizabethen-Jacobean convention, the poet is concernod chiefly with himself and his own thoughts. Despite the change from a musical to a spoken style the poem is more rhetorical than conversational, and Donne fails to oonvey the illusion that he is actually conversing with his wife at a particular moment. The poem is deeply emotional because the poet is concerned with his personal problems as an individual, as 
opposed to Shakespeare's apparently more narrowly literary concems in his 7lst sonnot. This rather straightforward attitude is reflected as the poet shows no consciousness of addressing an audience or literary clique. Mood does not play a large role in the piece, perhaps because Dorne does not develop the scene or background of the poem nor treat a specific incident. The emphas is always on clear logic rather than vague cornotation. A brief recollection of the poem will reveal that it possesses most of the hall-marks of seventeenth century metaphysical poetry at its best in its bold metaphorical use of the nane, skeleton and astrology, the web of abstract logic, the psychological realism of the problem examined by the poet, and the mixture of playful wit anci deop emotion.

Nineteenth century romantic verse loses most of the wit, logic and complexity of seventeenth century metaphysical poetry, but in turr anticipates a greater emphasis on musical and connotative values in twentieth century metaphysical poetry. I quote Christina Rossetti's "Remember," 1862 :

Remember me when I am gone away Gone far away into the silent land; When you can no more hold me by the hand, Nor I half turn to go yet turning stay. Remember me when no more, day by day, You tell me of your future that you planned: Only remember me; you understand It will be late to counsel then or pray. Yot if you should forget ne for a while And afterwards remember, do not grieve: For if the darkness and corruption leave A vestige of the thoughts that once I had, Better by far you should forget and smile Than that you should remember and be sad.

1. The neo-classie period is not important in the line of development of seventeenth and twentieth century metaphysical verse while, on the other hand, romantic poetry is an important influence on modern metaphysical work. Nor does the neo-classic period offer many serious contributions to the theme under disclission as the only thematically appropriate poemfound in an examination of neo-classic verse was Dryden's "Rondelay," in which both death and love are treated with complete frivolity. 
In its basie argument the poem is vory similar to the Shakespeare sonnet as the poot neither poses a serious problem nor prejects an experience, but simply asks her lover not to grieve for her when she is "gone away." In the former, however, the poet is chiefly trying to please through his skillful and clever hardling of a theme in the Renaissance "court of love" tradition, while Miss Rossetti, treating a very similar theme more emotionally, is more concerned with expressing the foelings imaginatively associated with this theme and in evoking noving sentiments in the reader. Its sweet iyricism is opposed to the tortuous mental conflict, the intricate logic and abrupt rhetoric of "A Valediction: To Ny Name in the Window."

Although the organization of the poem is essentially logical in the symmetry attained in the two quatrains and sestet of the sonnet, the method of propulsion in the poem depends heavily upon the psychological connotations of the phrases and ideas in the piece. Such expressions, for instance, as "gone away," "silent land," "no more hold me by the hand," "late to coimsel" and others seem to belong to a common associational cluster suggesting poignantly the tenderness and sorrow of parting. They not only holp maintain a unified mood throughout the poern, but also function in the reader's mird to suggest one another and similar enotive ideas belonging to the same cluster. This technique is developed in a more extreme form in nineteenth contury symbolist poetry, and is found in a great deal of twentieti century metaphysical poetry and other modern verse.

This process of connotative progression is rendered more effective 
by the musical quality and accentuated rhythm of the metrios. In this respect Wiss Rossetti tends to hark back to the lilt of such a piece as Shakespeare's 7Ist sonnet, and to register a dislike for the irregular, more conversational style of Donne. The visual images in the poom are vague and connotative, as in "silent land," while seventeenth century retaphysical figures have no place in the poera. Although there is a greater feeling of actual experience convayed in this poem than in the Shakespeare sonnet, only the margins of the experience, so to speak, are treated. There is no great depth of emotion, such as is found at some points in the Donne piece, but rather a small-scale emotive diffuseness, for the poot apparently does not wish to fornulate her experience frankly and completely within the pootic structure. She avoids all metaphysical complexity in treating only one aspect of an experience, introducing no wit, irony or ratiocination into her attitudes. It is partly for this reason that the sonnet approaches sentimentality.

The same nineteenth century romantic approach is reflected in the poet's point of view. Despite the similarity in theme, distinctly different viewpoints are represented in the Shakespeare and Rossetti poems. While Shakespeare utilizes the theme to pay homage to his mistress quite in the Elizabethan love sonnet convention, Miss Rossetti, as a Viotorian wornen, demonswatos a house-wifely concern for her lover's welfare after her death. While in the Rossetti piece a poet's interest in a lover seams to play a more important role than in the Shakespeare and Donne poems, she does not convey the notion of a distinct relationship or of a definite monent in time--ideas which the twentieth century 
metaphysical poet frequently does convey. Like most of the modern motaphysicals, she is a self-conscious artist, but her approach is porsonal and individual rather than philosophical or social, as is often the case today. Like Donne and unlike most of the modern metaphysicals, she does rot make her relationship with her audience, or readers rather, an essential part of the poem.

In a modern poen such as Yeats's "Broken Dreams," published in 1919 in "The Wild Swans at Coole," much of the complexity, the selfinclusive satire and the psychological realism of the seventeonth century retaphysicals is found combined with the psychological progression and emphasis on mood and tone of the romantios:

There is gray in your hair, Young men no longer suddenly catch their breath Then you are passing; But maybo somo old gaffer mutters a blessing Because it was your prayer Recovered him upon the bed of death. For your sole sake--that all heart's ache have known, And given to others all heart's ache, From meagre girlhood's putting on Burdensome beauty-for your sole sake Heaven has put away the stroke of her doom, So great her portion in that peace you make By merely walking in a room.

Your beauty can but leave among us Vague memories, nothing but memories. A young man when the old men are dore talking Fill say to an old man, "Toll me of that lady The poet stubborn with his passion sang us when age might well have chilled his blood.

Vague memories, nothing but memories, But in the grave all, all, shall be renewed. The certainty that I shall see that lady Leaning or standing or walking In the first loveliness of womanhood, And with the fervour of my youthful eyes, Has set me muttering like a fool. 
You are more beautiful than anyone.

And yet your body had a flaw:

Your small hands were not beautiful,

And I am afraid thet you will run

And padile to the wrist

In the mysterious, always brimming lake

Where those that obeyed the holy law

Paddle and are perfedt. Leave unchanged

The hands that I have kissed

For old sakes' sake.

The last stroke of midnight dies.

All day in the one chair

From dream to dream and rhyme to rhyme I have ranged

In rambling talk with an image of air:

Vague momories, nothing but momories.

I am sure thet the twentieth century reader with a taste for poetry, even before making a careful analysis, would krow that Yeats's "Broken Dreams" is in many rays quité similar to Donne's "A Valediction. To $\mathbb{N}_{\text {ame }}$ in the Window," and that it is both like and unlike Hiss Rossetti's "Remember". Its mature viewpoirt and its deep emotion combired with a rather satiric attitude towarc both the poet and one beloved is reminiscent of Donne, but the poem's essential simplicity, its dreamy, connotative quality, ard its smooth metries are pert of Yeats's heritage from the romantic, particularly the French symbolists.

As with Donne, Yeats is not nearly so interested in presenting a clear-out argumert that can be easily paraphresed as he is in examining the various facets of his experience as he considers the problem of his relationship with this lady and his attitude towerd her death. The poot is day-dreaming of Maude Gonne, whom he loved and watehed as she grew old and embittered fighting for the Irish revolutionist cause, and he glows with anticipation at the thought of seoing her again in the full beauty of her youth, but he hopes that in death she will not atrive to lose those little flaws in her beauty which he loved. 
"Broken Dreams" in its organization is sharply oposed to Donne's valediction. In place of the logical unity of "A Valodiction: To My Name in the Window," the Yeats poem has a psychological unity. Whil. the Donne piece is held together by an intrioate network of abstract ratiocination, Yeats's poom is built around the modulations and quick changes of his rambling thought. Although a poem such as this should be considered as a vital process rather than as a static structure, it is possible to think of it as blocked off into about fire main sections which treat varying trains of thought and oroke chenging emotional reactions. In the first stanze Yoats thinks with both nostalgia and bitternoss of Miss Gonne's loss of beauty, and then is lead to consider her life and his rather tempestuous relations with her over a poriod of years. In the second and third stanzas he thinks of his own approaching old age with a certain whimsy. In the last stanza ho considers Miss Gonne's possible rebirth, and concludes by returning to the theme of his own old age. These subjects are of course related, but they are not linked by any objective logic exterior to the poet's mind. As in a number of nineteenth century Balish romantic poems and Germon Lieder, there is an alternation of what might be thought of as major and minor moods. The method of progression, then, in "Broken Drems" is psychologioal, a kind of "stream of consciousness" dynamism that is a more extreme development of the connotative method found in Miss Rossetti's "Remember". Again, as in French symbolist verse and the German art song, there is a constant modulation betweon major and minor tones and varying degrees of intensity, an emphesis on connotative visual imagery, and a fundamentally musical structure. 
As in many of Donne's poems, the piece begins quite abruptly with a telling touch of realism:

There is gray in your hair,

Young men no longer suddenly catch their breath

When you are passing.

This suggests the fundamental antithesis in the poen between the uncompromising reality of the present and a remembered past of dreams and beauty. The scene of the poem is set, but it is set in the poetis rovin mind rather in the kind of physical milieu of the type suggested by the engraved name in the Donne poem.

After the opening lines the poet recalls that although his lady's physical beauty is fading, many remeinber her kindness. But he turns back again to her pe st beauty and his life with her, and is convinced that for him her graoe and charm will never pass away. But remembranoes of things long past bring him to thoughts of his ow approaching old age and these load to considerations of death and the hereafter. The myth of the "always brimning lake" comes into his mind, and wi th amusement he imagines this beloved lady bathing in the lake to restore her beauty and to make forever lovely her hands, which are not beauteful. But thinking of her hands, he remembers that he has kissed thera often in his youth and he feels again his de日p affection for this woman. His youthful thoughts again remind him of his age, and it is only here at the conclusion of the poem that the actual physical scene of the poem is set--the old poot day-draaming in his chair at midnight.

As I noted previously, there is a rise and fall, an emotional crescendo and decrescendo, in the poem, as in much romantic music. An emotional intensity is marked as Yeats thinks of the beauty and peace 
Miss Gonne can bring about,

By merely walking in a room.

This feeling dies down as he thinks of his age, but rises more strongly as he envisions her,.

Leaning or standing or walking

In the first loveliness of womanhood.

Afain the temsion lessens somewhat as he thinks a litile ironically of death, then climbs to the point of highest emotion in the poem as the old poet \&sks :

\section{Leave unchanged \\ The hands that I have kissed \\ For old sakes' sake.}

The doep foeling fades away in a kind of dying glow as the poet thinks of himself dreaming alone in his chair at midnight. It is also interesting to note the force of the poem's piotorial imagery, despite its dreamy, twilight character. The visions of Miss Gonne suggested in the piece are impressionistic, rather than sharply particularized, but even in their vagueness thoy are grasped readily by the reader's mind. In general they have a rich connotative value suggesting the poet's nostalgia. An examination of the poem will show a correspondence between the sharpness of the visual imagery and the intensity of the emotion.

There is also in this poein a sharp change in the way in which the meter affects the method of progression. As in the Donne valediction, the metrical structure bocomes irregular and conversational as it is subordinated to the meaning of the piece. The poem is then opposed to the Shakespeare and Rossetti verses where, if the poot makes any sacrifice, he seoks to improve the metrical music of his vorse tather than its sense. In Yeats's work we find Donne's harshness softened by the more melodic romantic metrics. 
But where Donne tended to be rhetorical in the Renaissance tradition, Yeats is informal, almost proseically conversational. Although the poem has no regular repeated refrain, there is a remarkeble rhythmic smoothness that se日ms almost to be music as it swe ps unbroicen through a number of lines--seven at the conclusion of the first stanza. These metrics are all-important in giving the offoct of a continuing, uninterrupted stream of thought.

In its rich complexity the poem is similar to "A Valediction: To No Name in the Window," and is characteristio of the twentieth century metaphysical style. It brings into clear perspective the breadth and maturity, the everpresent irony and humor foumd in Yeats's vorse as his dreamy romanticism and frank realism play upon one another. He suoceods in merging the glow of imagination with the plainness of reality as he considers himself as an aging poet and thinks of the bodily and spiritual perfeotions and blemishes of Miss Gonne, whom he lored. In the first section of the poem, with the mention in Yeats's homely idion of the "old gaffer," as opposed to the "young men," his description assumes a somewhat pejorative tone, but becomes deeply sympathetic in referring to Miss Gonne's welfare work with the poor and her service as a nurse in France during World War I.

Another antithesis developes in the next fer lines as the poet draws upon his deep understanding of this woman. She has not only endured "all heart's ache," but because of her beauty and proud, passionate nautre she has brought heart's ache to Yeats and others. Nevertheless she brings great peace by"merely walking in a room." 
There is a mixture here of a simple, abiding tenderness and a softened bitterness that is reminiscent of the closing stanzas of Donne's valediction as the seventeonth century poet warns his wire against infidelity after his departura. or death. Yeats's approach here is far more subtle and complex than his stabs at Miss Gonne's "intellectual hatred" and "opinionated mind" in "A Prayer for My Daughter."

The fine blendirge of realism and idealism in Yeats's view of this lady is revealed again at the opening of the last section of the poom. To him she is more beautiful than anyone, but yet he is conscious of an imperfection of her beauty. And there seams to be an insistent omphasis in the next fow lines--es though he were anticipating a protest: And yot your body had a flaw:

Your small hands were not beautiful.

Her vanity, by which Yeats is rather tolerently amused, is suggested as he fears she will "rum" to the lake and "paddle to the wrist." His freo-roving imagination is tempered with a satiric humor as ho conceives of a physicel rebirth. In his use of such a homely word as "paddle", as it is juxtaposed with the "holy law" and the "mysterious; always briming lake", the poet infers that there is something childish about this great woman and her devotion to her beliefs. This whimsical, rather satiric mood is followed by an expression of sincere affectionan affection deeply rooted in reality-mich I have proviously noted as the peak of emotional intensity in the poem:

Loave unchanged

The hands that I have kissed

For old sekes' sake.

Yests's matches this mixed attitude toward one beloved by him with 
a similarly depreceting attitude towerd himself. Despite his humor the poet is painfully aware that he is an aging man with nothing left but "vague menories" of her beauty. There is a berbed, self-inclusive irony as Yeats refers to himself as "the poet stubborn," recalling his long suit for the hand of Miss Gonne, who repeatedly rejected his offers of marriage. At the conclusion of the poem his romantic declaretion is immediately qualified by a note of poignant realism. He is merely an old man sitting "all day in the same chair," indulging in rambling day dreams of an "image of air."

This self-irony which sometimes, as in much of the early work of Eliot, amounts to self-pity, has come to be a hall-mark of much twentieth century metaphysical verse. This element is found also in some measure in seventeenth century poem as "A Valediction: To My Name in the Window" as Donne forsakes his role as metaphysical poet as though a little emused at his own rhetoric and speaks to his wife more seriously-out of charecter, as it were. In generel, however, the so-celled self-irony of seventeonth century motaphysical poetry is a playful, satiric wit more often than the type of nineteenth and twentieth century romentic irony that reveals the poet dissetisfied with himself and usually, more perticularly, with the inadequacies of the moderm age.

Yeats's point of view as expressed in "Broken Dreams" is considerably more modern then that found in any of the pieces so far discussed, for it is here that we find the poet most concerned with the varying aspects of relationships between two lovers. In the course of the poem Yeats and Miss Gonne are each etched clearly and the history of thei: relationship is sketched in bread terms. There is no need for any suspension of belief in the poem because the figures seem to have a past, to exist in an actual 
time and place environment, while in the velediction, Donne is concermed elmost entirely with his own ideas and conflicts. Donne's wifie is really not presented in the poem as either a peychological or physical reality, and the present of the poem seems almost wholly isolated from any pest.

Yeats's attitude toward his pootic material, including himself, is also altogether modern with its tinge of amused irony, but at the same time he does not share the propensity of a number of twantieth century metaphysicals to conceal persoral feelings behind a mask of impersoral, moro social writing. In this connection it is interesting to note that, elthough he is finished artist, he does not seom to write self-consciouslyr for a theoretical third person assumed to be representative of a certain literary or int llectual group.

The most important and most interesting ides arrived at through this study is the thesis thet twentieth century motephysical poetry is basically very similar to seventeenth century werse, but that it has been affected by both English and French nineteonth century romantic poetry.

In seventeenth and twentieth century motaphysical verse there is a thoughtful rummaging through ideas in an attempt to throw light upon some problems or experience, while in a great deal of romantic verse the poem is provided with a simple, appealing argument, and often there is virtually no problem at all. In the verse of both the seventeenth and twentieth centuries there are more contradictions of thought and emotion, making for complex, mature writing. 
Although there is virtually no use of motaphor in the particular Yeats poem analyzed, on the whole Yeats and other moderm metaphysicals make frequent use of metaphor, and use many seventeenth century logical devices.

The pictorial, visual character of most seventeenth century metaphysical verse is also found in most modern metaphysical poetry.

The influence of romanticism is seen in the psycholojical progression of the Yeats piece, its rather impressionistic painting of persons and visions, the connotative quality of its imagery, the subtle changes from a major to a minor key, its emotional modulations, and its more musical metrics. The romantic irony found in "Broken Dreams" has its roots in the nineteenth century, but this tendency toward self-pity and selfdeprecation has become typical of the twontieth century.

A twentioth century contribution is seon in Yoats's more familiar style, his more precise examiration of a human relationship, and his sense of an actual past and present impinging on life, as in his brief allusion to World war I and Miss Conne's service as a nurse.

In the next chapter I shall discuss more completely and speoifically the relation of twentieth century metaphysicel poetry to its heritage of seventeenth century metephysical: and nineteenth century romentic verse. 
CHAPTER II

POETIC PROGRESSION 


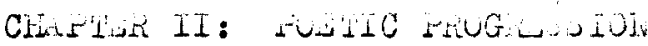

Changing modes of poot c progression in the seventasnth ano twentioth conturies will be conoiderod in this chater. An extrination

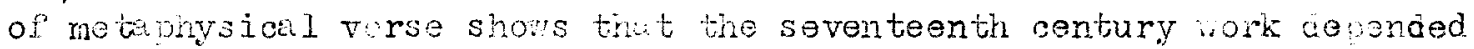
upon a potic organication and propulsive methods that wors fundamentally lorical, wile nodern methous of poetic prowression are esuentialiy psycholorical.

To study the orranization of a poen and its mothod of propression is to loor at virtuily the same churaterictios in two difierent ways, statically and aynanically. When we consicier the organization of a poen, we think of how it is blocked oft in space, of the various glanes on which it might be understood, and of the symetry and relation of its parts. To borro. some of the terminulory of Ransom, we think of the relation within the poen of its "structure, or paraphrasale arsument, and its "terture," the added particularity which is tanrential to the mein a rgument, modifying and develop n: the "structure" and clotining, it vith a rich variety, Wen consiar the methon of propulsion, or progression, within the poem, iz think os the poem as it is presented, line by line ard irage by image, to the inc of the reader. Whon vieved this way, the poom is seon es a foces ir. time, and there is a currert of meanire, logical or psychological or both, that roceos through it from begnning to end. The eecar is cerrised throvgh the poen by the interrelationshive of worls, inaes, ond ideas, as vell as by the rhythr or the rotries. A riece of music may be viewed in much the same way.

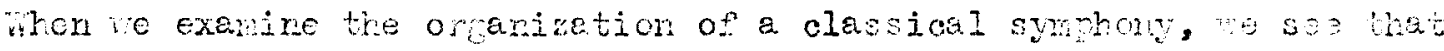


it has tour moverexts, that each novenent is usualy dividad ino three or mors sections, and thut the vork is based on a mues of different musicel theres. But the symphory, Iike the poem, must be considerec as a vital, milied proces which mut be presented to the mind of the Iistener as sonething that enrures sxa becones in tire. on? when we suspenc our concetione of the poen ene sym hory as urfoletio and rogressing, can we trink of therr as static, suejal entities.

Yeetr "Broken Drean", for exange is diviced irbo about five sections, ecch realire with a screwht diferert ascent of the poetis thollht, and there is a cortimons rise and lell of evotion in the poer. These are sirnificent oraniaticnal factors, but when ie red the poem we do not; corstice each sectior sevarately, but we are cerrica foride by the roet's row anc enotions, the asacojetion of jesas in the nina, as vell as by the undewing rhythe which affect the nower in wich the poem is porceived by no, phrase by phrese ond stonze by stanz. This cistir ction betwean poetic orenizetion and potic propresion can be illustreted in an excmintim of shakesjeere's 137 th soryet, one of about $\varepsilon$ dozen peces by the poet in wich strikin conceits and wit

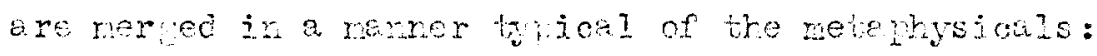

Thou blinc fool, Lore, what dost thou to rine eyes, Thet they behold, and see rot what they see? Whey know whet beauby is, soo where it ljes, Yet what the best is, take the rorst to be. If eves, corrext by over-partial lools, Pe anchored in the bay where all men ride, Wher of eves' falselooc has thonth fored hooks, Where to the juanement of my heart is tien? Why shorld my hart thin that a serorel riot indel no hert mows the wice vorld's common place? Cr rine eyes, seein this, say this is not, To rut fie truth uror so foll e. face? In thins richt true ry host and os hove erroc, An to this false rlarue we they now transerrec. 
The poer is talkable in a study of sevententh centry motephrsical roetro becanse in the relatively simrle logic of its oranization and promesion it anticinates the nore compex and ebstract lomid of Dome and hic suce tors. Also, as in most metabhyical poetmy, it is the poet's elebration of the arurent of the coen that is all-importart. The ard?rert, or structure, is quite simble. The poet is complain in a rether rhetorical maner thit his rerceptions and emotions, despite his better judgrent, are betraine him into love of a wormen wo soms to him to be most excoticnal, but in reality is perhams comon and promiscuous. Construeted around this structure is a terture which bring varticulerity and variety to the noem. There is of course the fundanentel antithesis betwen the eyos anci the heart and the strikin meterhor of the eyes anchored in the bay. Pararioz is employed in such phrases as see rot what they see," and "seein- this, say this is not," and other antithes s are su ested ir the contrests between "best" anci "worst", "feirl and "foul", "true" and "false", and "severel plot" and "comon riece." Trans in The Yew Criticism anc other worls hes discussed at length the vitel impowtence in metaphical poetry of this type of textural deteil clothire the stmoture of a roem.

Retumine to the orrenization of the roern, we see that it is altowether lonical and self-containec. The losic of the ooer is comparatively simple, as the thre quatrains and covrlet contain virtually the same staterent in different terms. In the first quatrair, shakespere acclises Lore of apfecting his vicion so that he takes the worst to be the best. Bmolovirs an oricinal retaphor in the second quatrain, he asks why his eyes are "anchored" on a common proniscvous woman "where all men rice," so that his heart is ens re red on the "hools" of his corrupted visior. 
In the thimi quatrein he uses another conceit, expleirino that he thinks of his mistress as on exceptinal "soverel rlot" while she is roally orly a "comon place." In the concludire courlet the poet decleres that his hert and eyes have rrobably erred, but that nevrtheless he must: continue to be wiced by them. In three sections the poet stirviates a rhetorjcal complaint to love about his corrunted vision, und ir the closine couplet concludes his objections lomically by exrlainin that he is resicned to the prejudiced vision of lovirs in whior he really fincs sreat hapiness.

This tyre of oranization, exterior to the nsycholo inal workinss of the poet's mind, is typical of seventeenth century poetry, ancit is noteworthy that the Bnglish somet, in which this ty of succinot, lomical oranization is cultivted, wes perfocted jut shorty betore the full flowering of seventeonth contry metaphysical verse. Wetchin. this lopical creanizaticnal fom is the logical method of promersion extendin: throuch the piece.

As in most early metaphysical poems, the method of propulsion depends upon a lomicel elaboration of a basic assumption found in some kind of learnin or in a staterent based on a neta wor, antithesis or sone other finde, In "A Valeciction: To liy Name in the Wircow" the propression depended on the metaphorjcel identifjectior of the poet and the inscribed window, and ir this sonnet it depends in a large measure on the shary and well-develoed antithesis betwen the eye and the heart, the outer nort and the inwarc part, the objective anc the surjective. This conceit not only mus through is somet like a umifying current, bindine together the sections of the somet, but aplears as a thene throuhout almost the entire somet sequence, 
exertin. a similer unifying influence. Growirg fror this imortant motive is a kind of chair of inter-lockin ideas and motaphors extendine throumout the poen. The sonnet is addressed in a conventicnal manrer to Lore, and the comor concontion of Lore as bind leacs to the corcertion of the "over-partial Jccks" anc the eyes that "see not that they see." Becanse the eyes are uver-partial and blind, they cannot wander freely with open-minced judrert, but are "anchored" securely to their object. In a mish of figures strun unon this thread of loyic the poet repers to the "bay," the crooked "fomed hooks," the heart "tied" to the hooks, anc the "vide vomld's comron place" thoucht by the hook-tied heart to be alseveral plot" special to it.

It can be seen easily in a close enalysis of this exly eramoe of netafysical verse that the noom would present several inconsistencics if int rproted accorire to a strict logic. The seconi gutrain, for exencle, must probably be thumt of as a series of assoojation conceits - rether than as an extended locical retaphor. Yet the somet propresses sroothly through a rather loosely comected chajn of rictorigl imanes easily wasped by the mind. In this quite early neterhysical fiece there is perhaps a greater emphasis on logio in the well-belanced symetry of the orantation than in the method of propression.

The 137 th sonnet shows an early and relatively simle use of the logical moce of provision. The chaning conceptions of the roem as process may be seen in an exarination of two main tyres of poetic proreasion-- the sevententh century locical mothod and the twentieth 
centum roycho:oridal method.

Logical proprossion: In a highly develored form such as is often found in the poetry of Donne tis mothod of promlsior characteristic of the severteenth century proceeds in a refined, point-by-point losic directly fror besic assumptions to logical corclusions within a framework of reas on that is fundarentally exterior to the poet's mind. As in much Baroque music, there is in a logical rogress on en elaboration and explomtion of thenatic material throun a precise, artistic hending of complexities of form and content. A frecuenty rhetorics l style and the use of rictorial metaphors and other fimures of speech is also chereteristic of this tye of progression. A strictly syllomistic mode of propulsion anc a looser associational moje are the fwo principlal variants of this type.

Psychological frorression: Wost tyrical of the trentieth century, this type of promression cloes not depend upon a logic exterior to the mind, but seems to express in a kind of Bersonien flow the cortinual flur and chaneine assocjetions and noods of the rind. This rocess sems to rive e more sensitive consiceretion to actual nsycholorical experience and to convey a mach reator sense of tive and duretion, essentials of most humen experionce. There is less emohasis on rhetoric and lorical figures of speech and a greater streas on corrotation, nuances of mood and musical metrics. Lorical elements often remain importart, but become subordinate to the fsycholosical provession.

There is, then, a funcamental, distinction between the lomical, chjective, denotative method of propression tyjical of the seventeenth century and the nsychological, subjective, comotative nethod charecteristic of the twentietr certury. 
lodem metaphysical poets retain sone aspects of the rlier process, but their arrosech is influenced and modified by a familiarity with nineteenth century ronanticism, including Frsnch symboljst poetry. A bries andysis of the method of propulsion in seventeenth and twentieth century metachysicel varse will clarify the majos difjerences between the Iojical and psychologicol rodes of progresgion. A much more advarced type of the same kind of lorical propulsion seen in Shakespeare's 7 lst sonnet is found in such a poem as Donre's "The Dissozution:"

She is dead; And all which die

To their first tiements resolve;

and we were mutual Elements to us, Anc made of one another. Wy body then doth hers irvolve, And those thirgs whereof: I consist, hereby

In me abundant rom, and burdenous,

And nourish not, but smother. liy fire of fassion, sighes of ayre, Water of teares, and earthly sad despaire, Which my materialls bee, But neere worne out by lores securitie, Shee, to my Icose, doth by her deathe renaire, And I micht live lonm wrotches so But that my fire doth with my fuell grow. Now as those Active Kings Whose foraine conquest treasure brines, Peceive more, and spend more, anc soonest breaks: This (which I an amaz'c that I can speak) This death, hath with my store Ity use encreas 'd. And so my soule more earnestly releas'd, Vill outstrip heres; As bullets flowen before A latter bullet may o'iteke, the pouder being inore.

The peem promresses logically from one sten to another, each deperdine upon the precedire one, very much as in the scholastic syllomism. Seventeenth century meterysical poems usially defend for their develornent unon sore bjt of erudition or a conceit, and "The Dissolution" is 
quite trpicel ir thet it is based on the scholastic theory of elemerts, althouch it also includes allusions to a more modern science. As Donno and his mistress were "mutual]. Elenents," irvolvirs one another, and all. things which die must resoive to their first elements, his lady's death, unburdening upon him a new abundance of these elements, threatens to prolone his life onc his misery resultine from her death. Continuine this psevdo-sciertific discourse logicelly, the poet ex lains that the oreater power created by the added elements will, as in an explosion, send his soul to outstrip thet of his mistress.

The sylionistic structure of the piece is quite apparent in the followine excerpt in which the parentheses, of course, have been adced by the present vriter to indicate more clearly the logical ormanization of the piece:

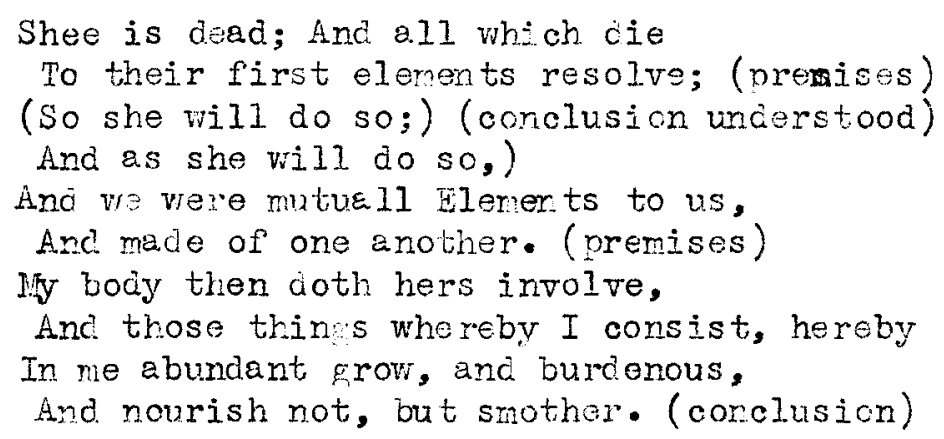

This tyro of organization, in which one syllorism seems to erow from and cepend upon another, is essentially different from the belanced Shakespearean cuatrains, each merely re-developing a fiven idea. There is much more of a real logical progression here, because the lines are interlockins, each dependirg upon the precedirs one and leading to the next.

There is also a subtler veb of loaic in the foet's method of orranization and proression, as these means are apperenty used to convey 
a muoh brodder intereretetion of the "cissolution." The first portion of the poem harks beck to an olcier age anc older theory in both content anc metaror, while the structure has a narked syllogistic charecter. As the poem proresses, howevor, there is a sumestion of a disso?ution of a vay of thirkin as the metaphors becomes more nodern in the alIusions to the cowder and bullets, as the form becomes freer, and es the poet's soul is released from its heavinoss. Most of the metaphors in the piece are of a scientific nature, but the latter reference seems particulerly to indicate an attomt to balance, metaphorically sosakine, the old. a. irst the new.

The imoortance of metaphor in developine and civins substance to this poem's abstract logic is easily aprarent. Follcwinm Shakespeare's Iead, Donnc employs the four tracitionel elements to express his passion and erief:

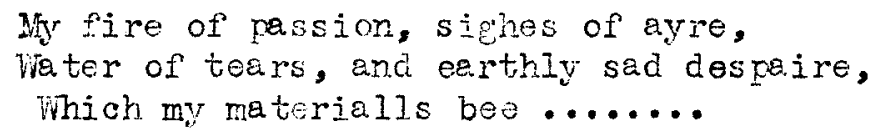

The irterdependent metaphors of the conquering kinss and the buliets are also essential to the prosrasion of the poem. These figures add a visual quality to the piece which complements in some measure the knotty abstractions and irregular rhythms which tend to retarc the reader's procress.

The psychological method of progession, characteristic of the twentieth centum just as the logical metrod was typical of the seventeenth, collc be illustreted by referrine to alnost any of the poems of Yeats, Eliot or the letter modern meta hysicals. Let us consider a brief one by Rliot, "Moming at the Window." 
They are rattline breakf'ost plates in basement kitchens,

And alone the trampled edces of the street

I am avare of the damp souls of housemeids

fprouting desconclentr at area pates.

The brown weves of for toss up tc rre

Tristed faces fror: the bottom of the street,

And tear from a passes-by with muc dy skirts

An airless smile that hovers in the air

And vanishes along the level of the roofs.

The title of the poer surests the scene of the poet standing at the window in the morning, and the body of the poom, erowire from mental impressions celled to mind by the scene and from casal observations, ir a continuin, changing streari of tisuel and aural iceas. The reader is never completely postive whet is peroeived by the poet and what is inagined, for in the nind the real anc the unreal, the immediately observed and the remembered, merge in an unceasine flow of chargin: combirations. The poen really takes lace withir the mind of the poet anc hes very little relation to the type of seventeenth contury locic wisch is exterior to the mind. The mind creates, modifjes and distorts in a psycholo ical world poised uncertainly betw, n reality anc fantasy. In this tyre of psycholorical propressicn connotation and suesestion tenc to supplant the denotation and carefully formated explication of the more logical approch. Despite their lack of logicel relationship to one another, all these images are calculated to sucest to the reader's mind the disapreable, wearisome routine of the commonplace in modern life. The feeline of loominess and decression that the poet feels hangs over the city is reflected in his referenoes to the ratting; breakfast plates, the streets worn by a monotonous tremnle baci and forth, the "camp souls" of housemaids at a rea gates, the brown gof and the mucidy 
passer-by who is probably a prostitute. As these images lead to one arother, it seens that their comnotetive value is a definite part of the poem's promesion. Eliot's connotative meterhorical ima es in this poem are of course closely related to the retarysical emohasis on metaphor and other fijures.

A stress on a logic which has its roots in medievel thongt is seen ir a number of sevententh century poems. It was Dome, hovever, who distilled this logic to its highest subtlety. For example, a very corplexly logicel elaboretion of a simle, quite nm-intellecturl idea is the rost important feature of "Lovers Infiniteness." iriting in a lisht amorous convertion that at first seems alien to the strict lo ic of the poer, Dome complains that he has no more simh or teers to karmain for his mistress' love, anc therefore if she hes after all only iren hin a nart of her lote he will never have it all. To illustrate Donne's method of woukin ont such celighted little love problems in terms of an almost mathematical loric, I quote the concludine two stanzas:

Or if then thou gavest me all, All was but All, which thou hadst then;

But if in they heart, since, there be or shell,

Nev Love created bee, by other men, Which have their stocks intire, and cen inteares, In sichs, in oathes, and letters outbid mee, This new love may becet new feares, For, this love was not vowed by thee. And yet it was, they ift bein cenerall, The rround, they heart is mine, what evor shall Grow there, deare, I should have it all.

Y.t I would not have all yet,

Hoe that, heth all can have no more,

And since my love doth every cay a dinit

Now growth, thou shouldst have new rewards in store;

Thou canst not every day rive me they heart, If thou canst eire it, then thou never cavest it; Loves riciles are, thet though they hest derart It stayes at home, and thou with losin: savest it: 
But wee will have a way nore liberall, Then chaning hearts, to joyne then, so we shall

Be one, anc one another All.

Besides the strict, self-contaired type of 10 ical prosression found in the poems just discussed, there is a looser, associational logic which provides a second important method of progession in sevententh century metaphysical poetry. This nethod, sucested in Shakespeare's 187 th sonnet, deviat s from the self-contairod syllomistic loric that seers exterion to the mind. The poem is carried forwar by more cesuel associations, rather then by a ridid point-by-point logic of necessity. there is a freer association of words and icieas, a logical l saine from one idea to $\varepsilon$ related one, throuch wich the poem geins a larper scope and tovches upon a meater, nore diverse body of material. This type of lçical progresion can be studied in such poems as Donme's "The Relique" and Horbert's Artillerie." In the former well-knorn poen Dome thinks of someone breaking oven the grave and fincing.

A bracelat of bright hair sbont the bone $\ldots$...

Ie wonders if the rrave diger will thing that a lovine couple lies thare mo us tì tis ciorico,

To make their soule.j, th the Inot busiz day,

Heot at this orave, and mele a little stay.

The poon concludes:

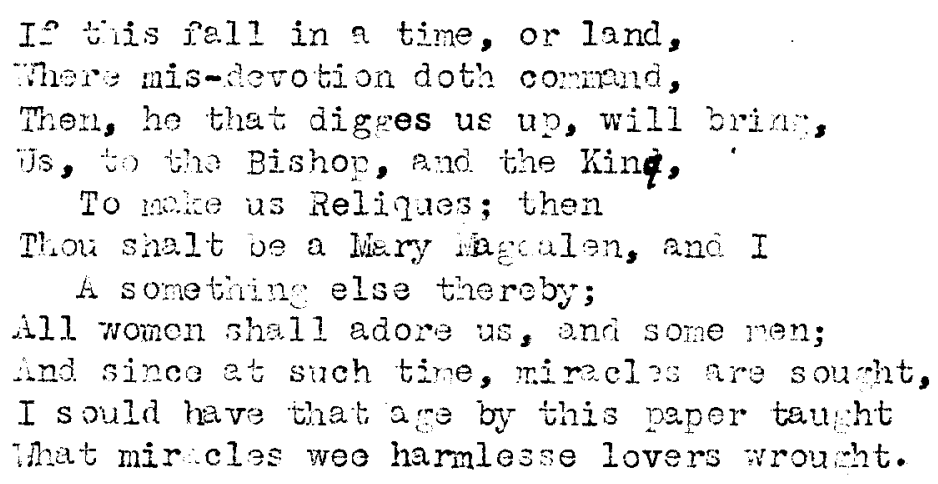




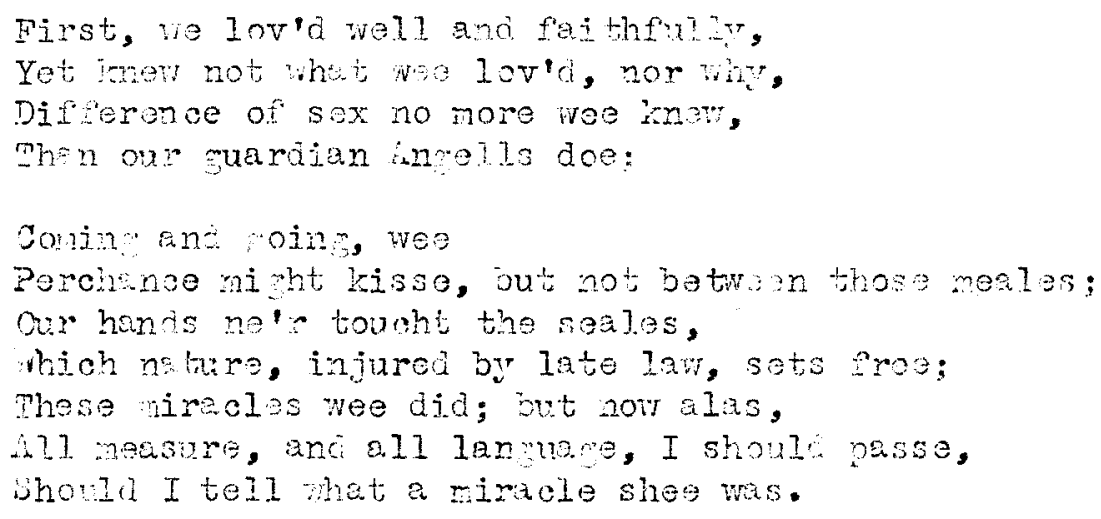

The promesis n soms easy ana smooth, but yet the are sevaral brotes in the continuity on thought in the poan. Openinn with a reperence to the grave uil the poe's buried with a "bracelet of bright hai $r$ " the piece procascs by association to identify the buried lovers with buried relics. As the mention of relics suerests miraciss, the poet at once enwerates the miraclis of love promed by him and his nistross and encs by telline wht a miracle she hersel was. Thes a anociationel 1seps are cont red in the second stenze, and the first and third stanzas, if exanined separately, would sem to heve very littlo ralation to one another besides the sinilarity in verse form. As in "The Dsnonization" anc other Dome poons, the unifyin factor in these associntions is the comparison of lore with relimion, the assupption that pure love is ebouts as stcred and rare as devout worship. It will be noted that the series of visual metewhorical inares is even more inrorbint to the propresion in a poen of this kind than in a more striotly logical piece. Another trojeal exanple of a lorion associational propession is Lerbert's artillerie:"

As I ne evening sat berore my cell,

Ife thought a starre did shoot into my lap.

I rose, and shook my clothes, as knowing wet?,

Thet from smell. fires cones oft no small mishep:

Then suddenly I heard one say, Do as tinou usest, disobey, Fipal sood motions Eron they breat, int ch heve the raca of tire, but ona in resto 
I, who hac heard of mustor in the spheres,

But not of speech in starros, becsn to musa:

But tumine to my Gor?, whose ministers

The stares and all thines are; i.f I refuse,

Drend Lord, sitd I, so oft ny rood;

Then I rainse not av'n with blowe

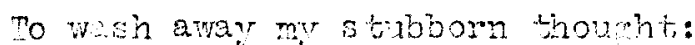

For I witl do, or sufer whet $I$ onght.

But I have also starrs and shooters too,

Born where thy sorvents both artilleries use.

zin toars ano prayers ni ht and day do wooe,

and worir up to thee; yet thou dost repuse.

Not but I an (I must say stil.l)

Weh nore obli 'a to do thy will.,

Than thow to rant mine: but because

They promise now hath ev'n set theo they laws.

Then we ane shooters both, and thou dost deine

To onter conbet with us, and contest

whth thine owne clay. But I would parley fain:

shmone not my arrows, and bohold my breast.

Yet if thou shumest, I am thino:

I must be so, if I am mine.

There is no articlin with theo:

I am but finite, $y$ t thine infinitely

The associationsl chein that links topetier all the varios stranis of tiris poen is not difficult to 101 low. The ontiro poen devalopes, of cours, from the poot's vision of the shootine star. From this reference prows the witty comperison of "music in the spheres" and "spech in starros," and cine Lora's allusion to "cood motions," Wich ireve the iace of fire, but ond in rest.

Thinking of the shootin star as God's artillery, the poet recalls

thet he can reply to his tord's fire with his ow batiery oi tears and prayers. This brin:s into the poem the concept of a brttle and Herbert speals of his arows, a perley and the poosibjlity of "articlin" with Gor. The batte fivre ladds to the word-play on finite and infinitely, light in style but serious in meanine, in which lies tine core of the poem. The easential loric or the varse is sean in the poet's construction or 
a complex superstructure preparine the vay for the single conclusion, as in the same poot's "The collar," an apparent revolt against spiritul renuciation that leacis to a reversal endine and a complete redediction to God.

There are a number of variations on the londal nethod of proression which is characberistic of seventeonth cantury netephysical verso. Basic, howevar, are these two types--the syllo ostic structure built around a series of pronises and onclusions, and the associative method in wich the poet proceads by a serias of lowical leaps from one ides to onnther.

Nevertheless on some occasions these tro imrortant methods of propulsion do not extend throu hout a poem completely, ani the riece is roclly oranized episodically, with the pot chenpine from one logioal systen to another. There is a mixtme oi these two logical modis on proprssion, for instance, in Donne's "A Fearsor" Identifynm his mistresi with the vorld's soul, the poet elabointes step by step upon this iuentification, considering her posible deth. Meanwhile the cosmologionl concept of the world's soul introcuces a sories of roferences to the destruction of the world, meteors and fimament.

Despite occasionalbraks in the continuity uf seventeenth century netaphysical poetry, almost all of this verse has a systom of abstract I0nic at its core. It is essentialiy a specizl verse, and in reading a serentsenth centufy poen we are seldor more consciovs of a sense of time and curation than we woild be in reacins a lenthy proposition in reometry. The vorse characteristically soms exterior to tine mina in that it is a reorganization of the poet's exporience in terms of refined losical forms and laws. 
Nodern inotaphrsical pootry in varying decreas prosents a fusjon of seventeenth century metaphysical techniques and nineteentih century romantio elemente. The modern metaphysicals hark back in some cases to a pronounced emphasis on the earlier method of lojical proposion while maintainine an essentially nodern anci psycholocical approch. I quote from the berinnine of mus. Wrije's "The Lotins Gup," which proves a characteristic iliustration of the modern motaphrials utilization of earlier techniques:

The instrument ot your reas on bein tuned

To the pitch of madness and desire to wound, You would not crink my halth save "rom her gless Who drinks my death: can such thines come to pass? But I considered, striving to bo just (Who strive not to be loving, for I must), Tha', we, yous vallals bound by every oath, Are thus your vessels, and you crint from both: That she and $I$, beine each of us a wonan, Taste the elixir of you lips in comnon; Thou I alone an privy to the fact; I have your half, and lesser then exact: Thet I, having swom I would devote my powers To advance her interesus as well es yours, Am therefore chattel of yourself and her And so divided into share and share. Should I not count me more unfortunato If from two cups you crank my single fate, Thain now, when both of you set lips to one And from its sole brim crink division? For rou have crunt ne joy and she despair In the same wine, that served you share and share, Eut never share and sinare alike: the mood In which iou drank transforned the wine to blood. Although your mood was black it did distill Such essencss as conld not uish me ill; hile she, who smiled to drink rny mortal nain, Broved hell itself within her smaliest vein.

The poen continues in the scme vein with similar finely-spun areuments, concluding with the puning firure:

The cup is loving, having kissed you once. 
The poet's essentidiy lopichl oprouch in tris poen is apdront. Iven the structure of the first four lines surests the law of cause and eifect. Because your reason has been turned away into madness, you eive yourself to her who vould drink my death, the poet says. There follows a froe poetic construction which nevertheless surests Done's use of tho syllomisn. The two prenises, introduced in lines 7 and 13 , berin: That; we, your vassels bound br every oath, and, That I, having sworn I rould devote my powers. The conclusion follows:

Am therefore chatiel of yourself and her find so divided into share and share.

Because the poet says in subsince, she und I are your vassals anci share you in common and because I heve sworn to advance the interests of both of you, I am therefore the vassal of both you ana her. The renainder of the guoted excerot is somewht reminiscent of Dome's "Lovers Infinitenoss" in ics cielicate web-work of psoudo-iogic and mathematios. Comiting the touchy problems or this relationship to the iovine cup figure, Irs wrie explains with suotle reasoning that she is gad her lover and her rjtal arank fron one cup instead of two, because his arinking from the cup distills the whole into essences beneficial to her. Since her lover has a role in this relationshin, it canot rally bode hor ill. Is in Donne's work, metaphor and word-play are vital to the meanin and promession of the poen.

Nevertheless "The Loving Cup" only partakes of a seventesnth century techniquo. In spirit it is wholly modern. The logic is not expounded rhetorically, as in most Donne poens, but veiled beneath an easy conversitional tone, similar to that found in "Broleon Dreans," which is opposed to both the rather pompous rhetoric of the sixteenth and seventeenth 
centurias and the ther sinssong rhytho of the nineteenth century The underlying logic of the piece is not so obvious nor so taut as in most early metaphesical verse, but becomes the framewort lor a muber of essentidly parenthetical remarics. "The Loving Cup" is also characteristic or most nodern metaphysical verse in that the poet presents a specific incident--the nonent when her lover and her ritral drank torether from the same glass, excluding har--and troats with extrene deftness a reiationship betreen three persons rather than showing a concern chiefly for herself.

This use of abstract logic is part of the heritage which twentieth century netaphysical verse has received fron the seventeenth century. A propulsion dependins upon a logical asjociation of successive words and ideas, as in "The Relique" and "irtillerie," is relatively rare in the twentjeth century, however, when such a chain of logic gives way to a psychological "stroam of consciousness" progresion. Even when lomic plays an important role in modem metaphysical verse, it is usuelly subordinated to this osycholo icel a proach.

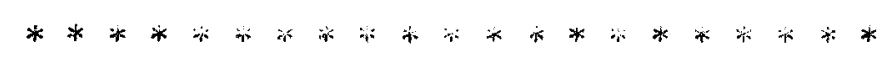

The new psychologiod prowession in modern poetry seans related to a Berssonien sense of low, durstion and unpredictable creativity, as opposed to the more rigid constmation of seventeenth century poens which deveiop a locical ar unent from becinning to conclusion. It also soms associtted with the rise of exoresionistic ari and lite:ature which treats a scene as taking place vithin the human mind. It cavtain represents one phase of an efrort to capture more of the living truth and. roality of huran experience. 
This psychological method of propression hus iws orinins in ronanticism, and it probably had its most airect impact on mocurn metaphysical verse throu Yeats and eliot, both of whom were influncd considerably by the Prench symbolizt poets.

A berinning or this psycholowal method of progression is found in nassames such as the sestet from this sonnet by Jonn Koats:

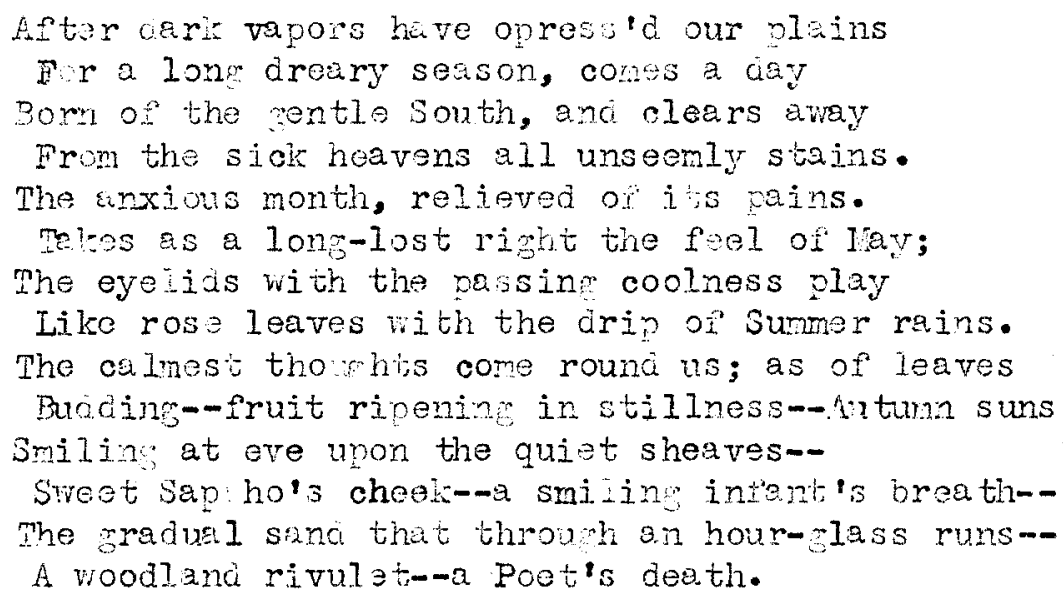

The procression here is perhaps somowhat artificial, but the passane nevertheloss sugrosts, as in Broken Droans", a froely roving mind operatine accordine to its own nature processes. The entire sestet seens held torether by the strongly comotitivo overtones of the poet's easy succession ol idie, beiny visions.

This same psycholacioul nocio of propression in a hicher stace of development is found in a rather sinilar French symolizi poem, Jules Lafor rue's "Crépuscule de Dinanche d'sté," in which the poet's thoughts seem to mell $u$, at randorn undar the intuence of the moody sumner evenin: Une delle journée. Un calme crepuscule Rentront, sans se douter que tout est ridicule, In frottant du mouchoir leurs beau souliers poudreux. 
A banale rancouer do notre farce humaine Aujourdóhui, jour de fête ot gaieté des faubourgs, Demain lo dur travail pour routo la semaine. Puis foto, puis travail, fôto...travail...toujours

Par lazures tendre et fin tournoient les hirondelles Font jo traduis pour moi les milles petits cris. Et peu a'peu je songe aux choses oterneliles, Au-dossus des rumours qui montent de Paris.

Ohl tout là-bas...la'bas.. par la nuit mystère, ou done es-tu, dopuis tant d'astres, a' prósent... 1 fleuve cheotique, $\delta$ Nebuleuse-mere, Dont sortit lo Soleil, notre pore puissant.

The Sundey twilight, petty noises of the street, thoughts of the weary monotony of existence, and a sense of the sublime mystery of life-all of these merge in a psychological progression within the poet's mind.

This method, found in a far more advanced use in the stroam of consciousness technique of James Joyce, Thomas wolf, and other, is carried to an extreme in such a piece as "The Heart's Desirg" of Mrs. Wylie, one of the more important of the twentieth century motaphysicals. The poem begins:

Anger tht is not anger, but bubblos and stars of colour, blood in the brain beating the nerves into a frenzy of inner light, magnified moons and suns swimning in the secret understanding that is more the body than the mind, the soul upon the lips for no reason at all, or at the sound of a door or the tinkle of gold and silver money in the street, faces best lonown and most remembered estranged and a million milos away, disange greasy faces passing in the dust of evening and now returning illuminated into godhead, oruelty where it cannot be, kindnoss where hatred is as inevitable as the white rising of a morning where morning may after all never more rise, disintegrate yet exquisite destruction of the heart at the moment of waking, desire for death like the vaggeness of a thirst for thin extravagant wino, unredeemed by fear, mortal and importumate someams of why, why, why in the extreme desolation of regained consciousness ...... 
Ideas, images, memories and worries float to the surface of the poet's mind in no perceivable logical order, and with only the thimnest psychological thread connecting them. The progression seoms to have its basis in the semi-conscious mind of the poet, while the reader also needs temporarily to suspend his concern with logic. The poem, filled with the connotative risual imagery and easy rhythmic undercurrent typical of much modern verse, retains virtually no vestige of that serenteonth century motaphysical logic which proceeds point by point through an argumant to a conclusion.

This psychological mode of progression is found in many variations and in differing degrees in most modern poetry. It should be noted, however, that modern metaphysical poetry also is characterized often by another form steming from the romantic tradition, a narrative or semi-narrative method which is frequently seen in conjumction with a psychological progression. This narrative type of progression will be considered after an examination of the more strictly psychological types.

The kind of psychological progression se日n in "Broken Dreams" and "Morning at the Window" is typical of the later work of Yeats, the earlier and more metaphysical pootry of Eliot, and of the verse of other modern metaphysical poots. This tectmique is illustrated vory clearly in several longer poems such as Eliot's "The Love Song of J. Alfred Prufrock" and "Gerontion" and Warren's "The Return: An Elegy." Certainly the musings, memories and fears of "Prufrock" have no actual scene other than the poet's mind, and the stream of his thought is responsible for both the breaks in the logioal continuity of the poem and the juxtaposition of different times, places and actions. "Gorontion" is frankly: 
Thoughts of a dry brain in a dry season.

In Warren's elegy, filled with the compressed metaphors and the complex clashes of irony and sensitive feeling characteristic of modern metaphysical vorse, the poot presses his faco to his Pullman pane as he returns to his Kentucky birthplace, and his mind, flitting from deep emotion to flippant sarcasm, wanders over the landscape, his new learming and childhood momar ies. After thinking of old ladies that "cough and wake" and of his dead mother, the poet continues in part :

Pursue down backward time the ghostly parallels Pursue past culvort out fill embankment semaphore Pursue down gleaming hours that are no more. The pines, black snore

turn backward turn baokward in your flight and make me a child again just for tonight good lord he's wet the bod come bright a light

What grief has the mind distilled

The heart is unfulfilled

The hoarse pine stilled

I cannot pluck

Out of this land of pine and rock

of the fellen pine cone

of red bed their season not yet gone

If I could pluck

(In drought the lisard will blink on the hot limestone)

In this elegy, "Prufrock" and other poems to quote from Eliot's

"Rhapsody on a Windy Night" :

The memory throws up high and dry

$A$ crowd of twisted things;

In a number of the shorter poems-and a majority of metaphysical poems are relative brief--are found the same emphasis on a besically psychological progression, a wide use of visual imagery and a familiar conversational style which avoids alike abstract complexities and motrical irrogularities. These qualities mark such pieces as Ransom's 
"Bells for John Whiteside's Daughter," the same poet's "Spectral Lovers," and Tate's "The Paradigm," I shall exmine briefly the former Ransom poem:

There was such speed in hor little body, And such lightnoss in her footfall, It is no wonder that her brown study Astonishes us all.

Her wars were bruited in our high window. We looked among orchard trees and beyond, Where she took arms against her shadow, or Harried into the pond.

The lazy geese, like a snow cloud Dripping their snow on the greon grass, Tricking and stopping, sleopy and proud, Who cried in goose, Alas,

For the tireloss heart within the littlo Lsdy with rod that made them rise From their noon apple dreams, and scuttle Goose-fashion under the skiest

But now go the bells, and we are ready; In one house we are sternly stopped To say we were sternly vexed at her brown study, Lying so primly propped.

With a lightness, a sophistication and a sense of humor in time of tragedy which are typical of modern motauhysical vorse, Rensom is here at the peak of his owm variety of "high seriousness." I shall refer to the poem again in a discussion of the complexity of experience in metaphysical poetry. It may seem a strange elegy to reader's bred on John Milton and Alfred, Lord Tennyson, and some of its strangeness no doubt lies in the fact that on the whole it is based on the natural flow of the mind rather than on a more artificial form.

As in Yeat's "Broken Dreams," the actual physical scone of the 
piece is realized only at the end when the poet speairs of the fumeral bells and the house where the little girl is so "primly propped." Brought face to face with her "brown study" the poet is astonished and recalls how he watched from his window as the robust little girl played with the ducks; but his thoughts are stopped short, so to speak, by the tolling bells which remind him of the funeral and the prim little body. Because the poem depends upon a psychological progression, it sesms quite natural--rather than out of place--that theee stanzas should be devoted to her undignified playing with the waddling ducks. They are for the most part not conventional fumerel thoughts, but they are the memories that come almost of neoessity to the poot's mind.

Typical of the most seventeenth and twentieth century metaphysical verse is the sharp visual clarity of the remembered scene "among orchard trees and beyond," and the house where the little girl is found in her "brown study." The completely easy, warhetorioal character of the metries and the language, however, and the setting of the poem as a spəcific incident, suggests twentieth century practice.

The narrative progression is another form which attained a rofined development in the romantic period before finding a new importance in modern metaphysical vorse. While not particularly popular with Donne and the serenteonth century metaphysicals, who favored exposition and argument, this old form regained new life in the more personal verse of the English romantics and to a lesser degree in that of the French symbolists. Endowing the narrative form with a characteristic touch of irony and complexity, many modern metaphysical posts have written a 
number of little poetic narratives which might be aptly described as parable-like. Ransom's grimly amusing "Captain Carpenter" and his soninet sequence of modern life and love, "Two Gentlemen in Bonds," are typical.

Another characteristic exanple is Tate's "The Paradigm" A brief narrative expounded in logical, somewhat abstract terns after the seventeonth century fashion, it is nevertheless presented through the mind of the poet, the third person who witnesses and reports tho soene from his own perspective, as in Ransom"s "Speotral Lovers" and other similar metaphysical poems, I quote:

For when they moet, the tensile air Like fine steel strains under the weight of messages that both hearts begr-pure passion once, now purest hate.

Till the taut eir is like a cold hand Clesped to cold hend and bone to bone Seals them up in thoir icy land (A fow squate foet) where into stono

The two hearts turnirg quickly pess Once more their impenetrable worlc; So fades out each heart's looking glass Whose image is the surfece hurled

By all the air; air, glass is not;

So is their fleoting enmity Like a hard mirror creashed by what The quality of air must be.

For in the air all lovers meet After they've heted out their love; Love's but the echo of retreat Caught by the sunbearns stretched above

Their frozen exile fron the earth And lost. Each is the other's crime. This is their equity in birth--

Hate is its ignorent paradigm.

The poem seens a little tale narreted through logical figures. Briefly, two former lovers meet, greet one another with a tense 
coldness, losing all their sensitive umderstanding of one enother. Their love becomes for the moment the "echo of retreat" and is lost. The poet concludes this iittle narrative, typical of a number of other brief meaningful incicients described by Eliot, Mrs. Hylie, Ransom, Warren and Auden, with a little philosophizing. This poen, however, depends chiefly on the extension of the metaphor of the tensile, steoly air. In its nogative aspect this binaing structure becomes the basis of a fine irony and gentle satire as the poet speaks of the lovers as though their quarrel is changing even the air about them, but in its positive aspect it is extended with strict logic on both the metaphorical and implied psychologicel planes. As the lovers are sealed in their few square feet of icy stares and mutual colcness of spirit their hearts are transformed into stone by the coldness, and each heart's mirror, which formerly reflected only the other heart (a Dorne device) is creashed by the "surface hurled/ By all the air," and the lovers' mirrored images fade out. The pair's doting love of one another seems destroyod by this new feeling - an artificial feeling the poet intimetes. The motaphors of the last stanza, as well as the use of logic, are reminiscent of seventeenth century practico.

Despite the importance of narrative and logical forms in the poem, the underlying method of progression is psychological. The reader is given the idea that the poet is witnessing the incident and interpreting it through his own personality. The physical metaphor of the "Taut air like a cold hand" is suggested to his mind by the lovers coldness of spirit. His observing of the inoident leads him to a little hasty meditation on lote and hate. 
The poem is ostensibly an attempt to describe this psychological experience of seeing and thinking about the lovers, and the poet's subtly complex attitude, gently ironic while sincerely sympathetic, colors and modifies this experience in his own mind. In numerous other modern metephysical poems, also, logical and narretive modes of progression become essentially submordinate to the psychological method, which is a hall-mark of modern verse and of modern metaphysical pootry in particular.

It is seen, then, that the method of progression in seventeenth century motaphysical poetry is ossentially logical, primerily abstract and syllogistic; as in "The Dissolution", or logically associational, as in "The Relique." There is on the whole a great. w subtlety and variance, however, in the modes of progression in modern metaphysical verse. This twentieth century poetry retains certain logical seventeonth century forms, but in its method pr progression it is essentially psychological rather than logical. This psychological approach and a greater interest in narrative are a contribution from nineteonth century English romentic pootry and French symbolist pootry, as the twentieth century concern with abstract logic is a heritage from the seventeenth century. While the conversational tone of modern metaphysical verse was suggested in the rhetorical seventeenth century variety, the easy, familiar conversational style of twentieth century metrics was not attained without example of the more musical, regular forms of the intervening romentic period--an example which Eliot, Yeats 
and others revolted against, however, in attempts to arrive at a freor style and more natural convorsational rhythms. It is difficult to overemphasize the importance of sharp visual imagery, metaphors and other figurea cheracteristic of both seventeenth and twentieth century metaphysical pootry. 
CHAPPER III

METAPEOR 


\section{CHAPTER III: METAPHOR}

Becalise oritics and poets alike acknowledge the importance of metaphor as a hall-mark of metaphysical poetry, its utilization in the seventeenth and twentieth centuries deserves special attention. As I noted in the preceding chapter, Brooks asserts that the "Significant relationship" between early and modern metaphysicals lies in their "common conception of the use of metaphor." And Ransom, writing in The World's Body, explains that seventeenth and twentieth century poets have "the courage of their metaphors," proceeding from a "partial analogy" to a "complete identification" through a kind of "miraculism." I

Neither these critics nor others, however, have treated the fundamentally different functions of metaphor and other poetic figures in the metaphysical verse of both periods. This changing use of metaphor parallels very closely the changing methods of progression just discussed. Two main types of metaphor are found--reflecting the same trend from the logical to the psychological seen in the study of poetic propulsion.

Logical Metaphor: This type of metaphor, most typical of the seventeenth century, is characteristically a logical, extended interpretation of something in terms of the metaphor more vidid and understandable and is intellectually pleasing because of the aptness and ingenuity of the logical elaboration.

1. Ransom, John Crowe, "The World's Body, p. 135

2. In discussion of metaphor I shall use the terminology of I. A. Richards who employs "tenor" to refer to the basic situation or theme which the metaphor describes and "vehicle" to refer to the figure ampligying or illustrating this basic subject. This combination of tenor and vehicle is the "metaphor." 
Usually something abstract is explained in terms of something more sensate and physical. A logical metaphor often depends upon a direct predicative statement of identification in which the comparison, like seventeenth century progression, is essentially exterior to the poet's mind--logical rather than psychological.1

Psychological metaphor: In this type most characteristic of the twentieth century, the logical aptness of the metaphor becomes less important as the figure is used mainly to eroke a mood, to suggest a very subtle experience, or to express a satiric or ironic attitude.?

1. Mario Praz in his Seventeenth Century Imagery notes the close relation between the seventeenth century metaphor and the emblem, which usually consisted of a small representation of a symbolical nature and an accompanying motto, and was in many ways an illustration of a conceit of metaphor. On the other hand, a metaphor may be described as a worl picture of an emblem. In both forms the stress is placed upon concentration and the striking representation of che thing in terms of another. Probably the first English work to treat these emblems was the Choice of Emblems, by Geoffrey Witney, a contemporary of Edmund Spenser.Besides the verse of the poets under discussion, the works of Thomas Nashe, Robert Greene, John Marston, and John Febster reflact a knowledge of these devices, Praz explains.

Praz quotes an interesting passage from a Renaissance figure, Danielle Bartoli, which is most significant because, although it was intended as a discussion of the emblem inlays, it is equally relovant as a commentary on seventeenth century English metaphysical poetry. I quote:

Is not the source of wonder, and therefore of delight, in such works the fact that one sees one thing used to represent another? The conception being all the more innocent in that in the whole composition of a false thing there is yet not one element which is not true. The same happens when we take anything from history, from fables, from nature and art, to represent something in the moral order which it is not in such a way that there should be so much appropriateness and correspondence of reciprocal relations between truth and its likeness that the whole, so to speak, should not seem to be an artifice of the brain, but the philospphy of naturo, as if nature had written almost in cipher her precepts everywhere. (p. 15)

2. Metaphor plays an important role in the work of several modern 
The psychological metaphor is sometimes extended elaborately, but in

its most typical twentieth century form is concentrated and compressed. The metaphorical identification may be relatively vague and grow apparently from a subjective, empathetic state of mind.

poets not treated in this study, such as Hart Crame, E. E. Cummings, and Archibald MacLeish. In "For the Marriage of Faustus and Helen," "Lachrymae Christi," "The Broklen Tower, "The Bridge", and other pieces Crane employs a mass of ever-changing metaphors which, however, are often exceedingly subjective and expressionistic, sometimes rather intuitional in character, frequently lacking a certain precision in their interpretation of experience which tends to be characteristic of metaphysical verse. "The Broken Tower" is an extreme example of Crane's overwhelmingly intense, and rather vague subjectivism, but provides a clear illustration of the general trend of his metaphorical expression. I quote the first four stanzas:

The bell-rope that gathers God at dawn Dispatches me as thought I dropped down the knell of a spent day--to wander the cathedral lawn From pit to crucifix, feet chill on steps from hell.

Have you not heard, have you not seen the corps of Shadows in the tower, whose shoulders sway Antiphonal carillons launched before The stars are caught and hived in the sun's ray?

The bells, I say, the bells break down their tower; And swing I know not where. Their tongues engrave Membrance through marrow, my long-scattered score of broken intervals... And $I$, their sexton slavel

Oval encyclicals in Canyons heaping The impasse high with choir. Banked voices slain! Pagodas, campaniles with reveilles outleaping-0 terraced echoes porstrate on the plains:--

One metaphor is piled upon another as clear tenor-vehicle relationships and a sense of intellectual control seem to venish in a maze of connotation. Metaphor used in this way is a potent element in an intense expression of a single viewpoint, but is not characteristic of the mixed attitudes and complex treatment of experience associated with metaphysical poetry. I wish to re-emphasize that there is no clear-cut qualitative difference between the work of the modern metaphysical poets under discussion in this paper and that of a number of other comtemporary poets. The metaphysical elements are simply quantitatively most important in the verse of seven English and American poets named in Chapter I as the chief modern metaphysicals. There are a number of metaphysical. uses of metaphor in the work of other twentieth century poets, such as "Landscape as a Nude" from MacLeish's "Frescoes for Mr. Rockefeller's City," but the employment of metaphysical metaphor is quantitatively and consistently most important in the work of the seren poets named. 
Virbuliy the same proces of cevelomert so was noted in tho chantrom methes of propession can we seen in the cas of mataphor. Modem metandrsiccls roots retain an juterest in these seventecnth

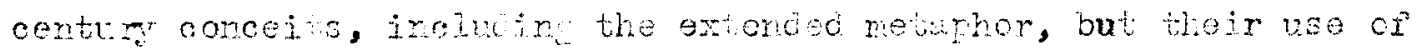
metaphor is tremercous affected by the softening influence of an

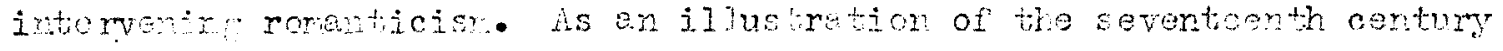
Iorcal neturhor I quote prom Done's "fyme to God If god, in Iy Sicinesnes."

Sirice I sn comirs to that Foly roome, here, with they use of dints ion evermore, I shell be made thy tusigwe; fs I come

I tore the Instrument hare at the core, And whet I must doe then, thinle here before.

Whjis my Physitians by the ir love cre mowne Cosmonransw, and I their vare, who lie met on this bed, that br them nay be showne That this ry south-wost discovorie Per fretur febris, by these etreich to die,

I for, thet in these streits, I seo my west; For thouh their currants yeelc returne to none, What shell my Nest hur me? ds liest and bast, In ali flett iaps (and I am one) are one, so lesth doth touch the lesurrection.

Contimine to experd unon the imilictins of the cooranical

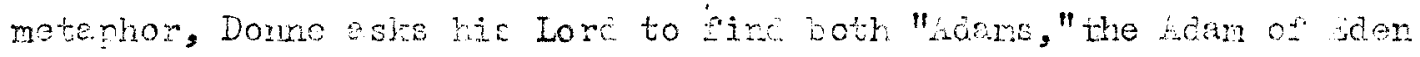
and the christ of Calver, mot in hine Dome concludes in eskine cod to rajse hir from desth.

Throu hout the poen the develorrent of metaphor carends uron a lomical identificoticn. In the first stenze the root ermleins that ho will be tho Iom's moto after his death, and that he rust therefore "Tune the Instrument" and reherse the celestiel concert to cone.

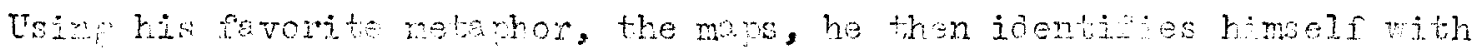
a flet may, and his theicians with comogrephers Bxtendin the metafhor sylloweticelly, he reasons the sined he is a mon, ard west eno 
east meet on all maps, his death touches his resurrection. In a similar metaphorical identification he identifies his death and resurrection with the "South-west discoverie."

The psychological metaphor characteristic of modern metaphysical poetry can be seen to advantage in a passage from Eliot's "The Love Son of J. Alfred Prufrock," a poem in which the psychological method of progression is clearly dereloped:

The yellow fog that rubs its back upon the windowpanes, The yollow smoke that rubs its muzzie on the window panes

Licked its tongue into the corners of the evening, lingered upon the pools that stand in drains, Let fall upon its back the soot that falls from Chimeys, Slipped by the terrace, made a sudden leap, And seeing that it was a soft October night, curled once about the house, and fell asleep.

It is quite true that the poet's comparison of the fog with a huge, dirty mongrel seems quite apt, as both may be found in the evenings in streets and passageways, curled outside the doors of well-lighted houses shut against them. But it is obvious that he has no concern with a logical point-by-point comparison of the two, and merely uses the yellow fog and the sooty dog because of their psychological connotating of disgust and of the petty insignificance of modern life. It will be noted that there is no actual mention of the dog nor identification of the tenor, the fog, and the vehicle, the dog. It is probably more correct to describe both as metaphorical vehicles to which the poet's mood serves as tenor.

Just as Donne sought to clothe theological and logical abstractions in physical images appealing more sharply to the reader's imagination, 
Eliot is here seeking to express the complex subtleties of a particular state of mind in richly connotative figures, employing what he terms an "objective correlative." In fact metaphysical metaphor and Eliot's device of the objective correlative are closely related, but the poet himself emphasizes the psychological elements inherent in the latter. In his essay entitled "Hamlet", he explains that "the only way of expressing emotion in the form of art is by finding an "objective correlative;" in other words, a set of objects, a situation, a chain of events which shall be the formula of that particular emotion; such that when the external facts, which must terminate in sensory experience, are given, the emotion is immediately eroked." 1

In the passage quoted above the fog itself may be considered as an objective correlative of the petty, sluggish spirit of our age, and the dog may be interpretgd as representative of a tameness and domesticityparticularly the nondescript mongrel, a parasite on human society. The figure apparently carried considerable power as a psychological symbol for the poet who, life Shakespeare, seems to show a dislike for the breed. In "The Waste Land" substituting a dog for John Webster's wolf, he warns: Oh keep the Dog far hence, that's friend to men-

Dogs apparently represented for Eliot the forces of living death, as opposed, for instance to the wolf of Webster's play or to the tiger of Eliot's "Gerontion."

A further examinaticn of the use of metaphor in seventeenth century and modern metaphysical verse will show that despite numerous variations these two main types, logical and psychological, represent two basically different viewpoints.

1. Eliot, T. S., Selected Essays, pp. 12/4-25 
Herbert's "Jeredise," wj.th its inreni us metaphricul rhme schere, for instance, is constructed around a use of the lomical metsinor only slinhty different from that in "Hymne to God sh God, in $\mathrm{g}$ er sichresses:"

I bIesse thee, Lore, becruse I Grov: Ar:ne thy tress, which in a $x$. To thee both fruit and order or.

Wet oven force or hidoen Clitir Cen blest my fruit, or brirs me Find while the inclosure is thine ARI. Irclose ne still for fear I STRT, Se to ne rether sherp and IART

Then let me vant thy hand and RRT. When thou dost rreater jud ments isfiRA, And with thy knife but prune and PAD, So'n fruitfu? trees nore fruitful itw.

Such sharpness show the sweetest Fund: Such out ins rether heel than RiID And such boinnios touch thejr $M I D$.

Athov rht the is no direct statement of icentification, the roen depends uon the metephorical assumpion, posited it the becimin, thet the root is a trea in cod's rardan. From this prerise the piece is extended lofically throvg five starzas, with references to the row of trees, their fruit, the inclosure, and the muing lnife. The poom, which j.s ircorceitrabe withont the metwhor, is a sain an ertended exrosition of a comprison fundamentally exterior to the poot's mind.

There is another type of escentially lopicel metaptor, often foun at its best in the sonnets of Shekespeare and other ilizobethens, in which the roet does rot ouite proceed to the bold, complete identificction cherecteristic of the fuli-blown metayhrical style, but only exneins sorothirm ir the lan uege and tems of sometoing else. As en iliustration of this mexed netaphor, I quote Shelespearo's 87th sonret: 
Farewell thou art too dear for my possenin, And like encu,h thou now'st thy estimate:

The charter of thy worth pives thee releasing:

Iy bonrs in the are all deteminate.

For how do I holc three but by they mentirn?

And for that riches where is my deserving?

The cause of this fair gift in me is vanting,

finc so my putent back a ain is swervin.

Thyself thou avest, thy own worth then not lnowing,

Or me, to whor thou mavest it, else mistaking;

So they rest rift, unon misprison crowirn,

Comes hore acain, on betiter judment making.

Thus have I hed thee, as a dream doth flatter,

In sleep a kne, but waline no such ratter.

The poet is here clearly cefining his amorous reletions in the

technical terms of finance, takirs pleasure in extendine the elaborete

fimire for its own sake. This type of metaphor is founc in a complex

develoment in a numbor of Donne piecs, such as "The Extasie," "A

Lecture toon the Shedow," and "Loves Promress,", but in the more fully

derclored seventeenth century metaphysical style an entire roem is seldor:

based on this tyo of metaphor which usially only refers to the vehicle

in its treatment of the tenor.

Wocorn mete hor, like the modem methoc of promession, show the use of seventeenth century elements in a tycicslly mocern fashion. In fact Ins. Wyie has presented in her four-sonret riece, "h Red camot for sheliey," one of the most interestin and elaboreate extenclec motaphors founc in ejther seventeenth century or modern metaphysical verse. The figure of the red cerpet reneins througinout the poen as a slender unifying threac, a symbol of the real theme of the work-Mrs. ylic's desjre to express her admirution of Fercy Bysshe Shelley and pay him homa:e. The sequence begins: 


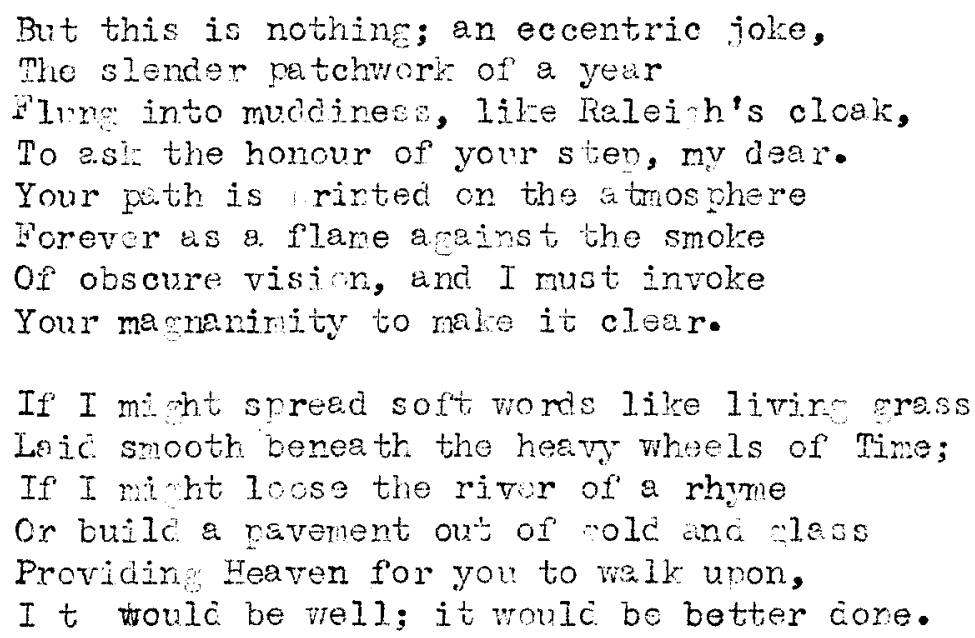

In the second sonnet she cortinues to surest an association between the rua and her poetry, with the cexpet in its actual and symbolical sense intended as homere. She "fabricates" language from spirit anc "braics into speech. the airy filarents of love and rete." In the thirc sornet she discusses the color and desimn of this carret and her verse, speakin of the telentos she has to ofter in tribute: I heve the prooer scarlet of my teins, The clean involvec precision of my rind...

In the last somet the poet declares she will lay down her carnet,

Where you may pause, and pass, and retrar stay.

She then considers tre carpet as a lone road which leuds shelly past the rich and changing lancsce which is her poetry. The peon concludes:

Here are the shocks of raize, the honey and oil, The fruits like harvest mocrs, the f'abulous land, The cystal hilis, the veiled prismatic plain; And you will core, and you will not remair, Nor leave a trace alon the miled sand. So presently you will be come and rone; Here's a strange roid for you to walk upon.

Al thouch the essentially seventeenth century device of the extenced motabhor is arried to an extrome not often found in earlier metarhysical verse, it is not, develoned lorically with a clear point-by-point reletionshin between teror and vehicle. 
There is a vameness about both as the roet's mind shito lanuidly from one image wnd conception to another. In the first somet, for instance, the "carpet", the vehicle of the metaphor, becones closely associated in rapd succes ion with "an eccentric joke," "Raleich cloak," "worce like livinu guess," "the river of a rhrme," a paverent out of colc and jlass," and Heaver. The poer also often depends for its effect unon psycholcicil comotetion, as ir the completely illonicel metachor at the conclusion of the second scnnet:

I would unrols the rouncied moon and sun And knit them un for you to walk upon

Modern osycholo ical coreeits are emloyed chiefly to sumest a mood, to express a subtle sycholo ical exp rience, and to exrress a satiric or ironic viempoint. Nost often, of course, there is a mixture of these functions.

Metapiors conveyine a sense of mood, such as the for ficure in "Prufrock," seem to have their roote in the comotative incosy of nineteenth century ancish romantic poetry and ir French symbolist verse. The symbolists' use of netaphor to express a state of mind can be stuoied ir. "Mecitation Grisatre," a sonmet written by Jules Laforme, with whose work Eliot wes quite ramiliar. I quote:

Sous le ciel pluvieuy noyé do brumes sales, Derant L' Océan blêne, assis sur un îlot, Sevi, loin de tout, je sone, au clapotis du flot.

Dans le concert hument des movrantes rafales.

Criniòre echevelée, ainis que des cavales, Les varues se tordant arrivent au calop it croulent a mes pieds avec de lones sanrets ju' enorte la turmente aux haleiness bruteles. 
Lartout le prenc ciel eris, le prouillard et la mor, Pien oue 1 'affolement des tents balavant l'air.

Flue d'reures, plus d' humaines, et solitaire, morne.

Je reste là, perdu cans Ithorizon loirtaine

it sone que $l$ ' espece est sans borne, sens borre,

Et quo le "emos $n '$ aura jamais...jamais de fin.

The conpurison of the waves of the sea to the sumin ly expiring horses adds a note of fantastic unrelity to the poen thet heintens the mod of meditution and cejection, ard prepares the vay for the rather mystic conclusion in the sestet. This filure, fairly vell developed in the second quatrein, appears altocether as a product of the roet's chandine thountis as reflected in the rsycholonical propresion of the sonret. Irociern metaphrsicel motaphor abounds in numerous examples of psycholo ical metaphor utilized to evoke a perticular moca. There are many pieces like Mrs. Mlie's "Merelese Sorm," in wich the locic is conoletely sucordinated to the emotive and comotetive cuelitjas of the metaphor:

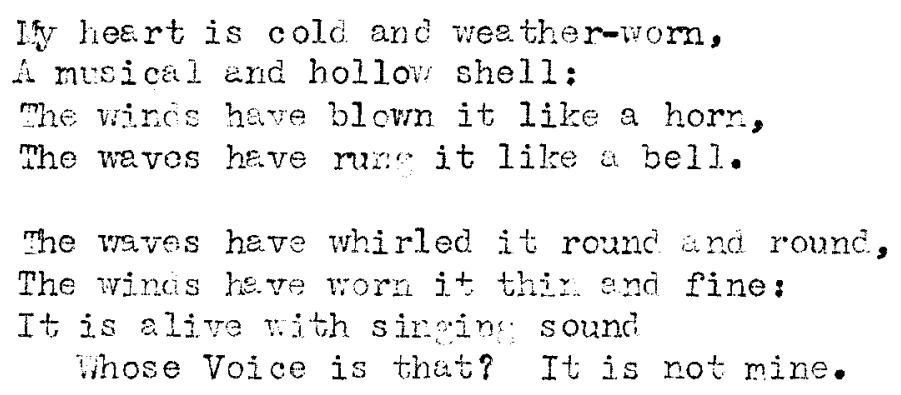

And there is the efiective synaesthesia in a metaphoricai nassare from the same poot's "Tiennese Haltz."

How falling, falline, feather after feather, The maic spreads a softness on the rounc; low for an instant we are hela tomether Hicicen witrin a swir in mist of sound.

A Doen filled with the compressed, comnotativo metahors charetoristic on modor metephysical poetry, particularly the southem verse, in Rnson's iels. known "spectral Levers." 
In such a piece we find the rovih-hem techniques of Dorre trimac and refirned to apreal to the artistic tastes of a sophisticated twentietr century Southern centlenen intensely concerned with nuances of mood and tone. I quote:

By nisht they haunted at thicket of ifril rist, Ls out of the strence pround stranely cone to sinth, Ise tro innculate anejs fallen on earth. Lopore they kner they wre, but whr unclasper, unlissed? Why should two lovers o frozen asunder in fear?

ind yot they ware, they ware.

Cver the shrecirine of an Aprij biosson Her thrilin" fincers touched his ovicl ith care; of miny dolicete lostures she cest a snare; Fut for all the red heort beeting in the palo boson, Eer face as of cuminkly tinctured ivory hias hare with an erony.

Stomed by the lithle batteries of an April niwh Fassionte boing the essence of the field, Should the onetrable wails of the ammlino prison yield? And oben un her treasure to the pirst clanorous kri ly "Tuis is the red roon, and wet I surrender all? If' he but sa it. I hall."

ful mesturing larely to the very moon of sester, Inoine his sters and swiskin the jubilant cress, the behoadin: sore field flowers that had cone to nass, Ee lad reducd his tributarjas faster, Hac not considerations pinched his heart Jufibly for his art.

"Mr I reeling with the sap of Aprii like a crunlerd? Blessed is he that taineth this richest of cities Dut it is so stainless the sack vere o thousand ritias; This is that martle fortess not to be conquered, Lest $i \mathrm{~s}$ white peace in the black fleme tum to tinas And an untterable cinder."

Ther rast mo once in spril, in the mist. lio otrer seeson is it, when cne walks and discovers, Two clad in the shep of anels, beine srectrel lovers, Treilirm a mory of moon-old and ametryst, Who toveh their quidi fingers like a bird Whose sons shall nover be heard. 
The moen is representative of the southern metaphosecl tracition at its bost. The richly complex attituce oi symetry and sotire and the munerous concentrated metaphsice? floures are presented in psycholowen proression in which the scene is revealed thronch anc in somo measure is a procuct of, the noet's mind. The metaphors and othor finures in "spectral Lov rs" achicve a variety of effects, but more then on the they create a mood and atmospere with is in mony weys the raison d'etre of the piece.

Cheracteristic of a larme body of modern matanysical vrsa, the netaphors an other figures in the pieco are compessed, subordintes, and far less obvious than in most of the work of Donne, Iterbert, and

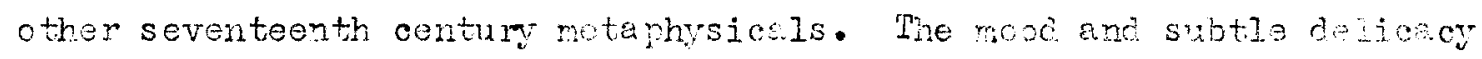
of the poer is sustained by the strongly connotative quelity of tro anithetical motaphorical systers that aro such an intogral port of the work thet they are scurcely noted as metarhisical devicss. In the first, the lcvers are yosented as ghosts or spirits. Renem rofers to the pair as "two immenlate lorers" on es "yro cad in the shape of anrejs, beins

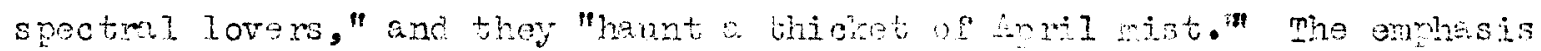

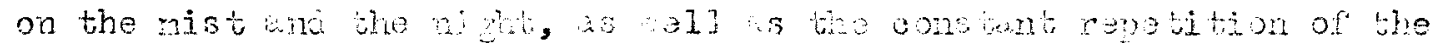

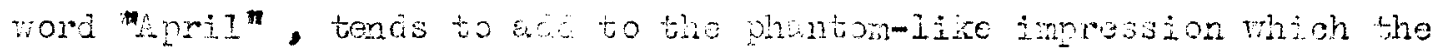

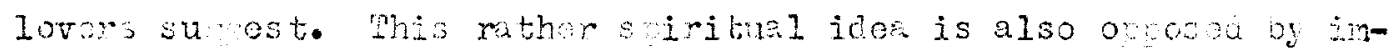
plicuion to the rore rital and sensul ides of sox, spring and now

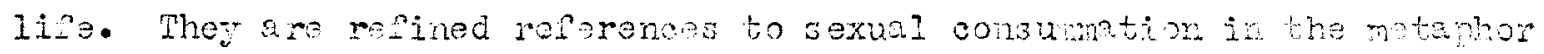

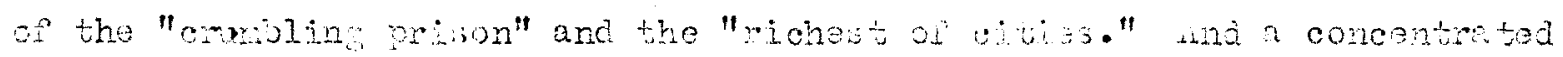

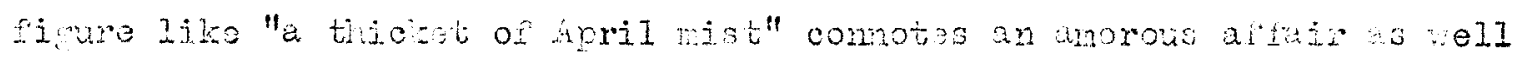

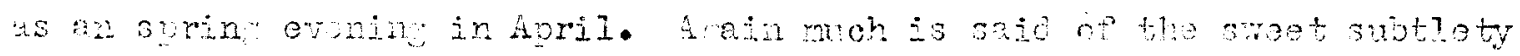




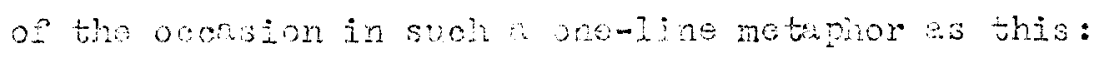

$$
\text { of mont cielicate postures she cast a snate. }
$$

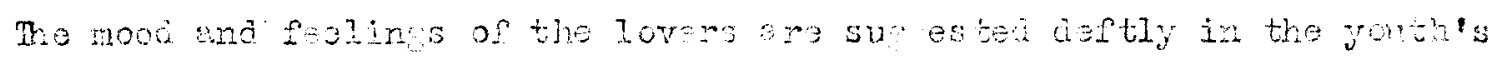

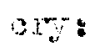

"An I regine, the tho 30 of Ariz like a druzara?" In fimres woh as bis the compresiod, nsyoholorical comotativa netewhor of the trentioth contury in found at is best. Whe say is of

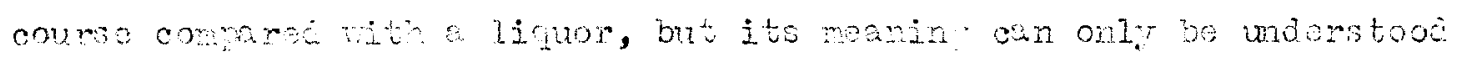
Whon it is soen in the contert oi the poen as symolizing sprin. Thus sw, wich has somelh: in common with both liquor and sorind, is used metanorioly as a lind of common denominator to help sis sociato the

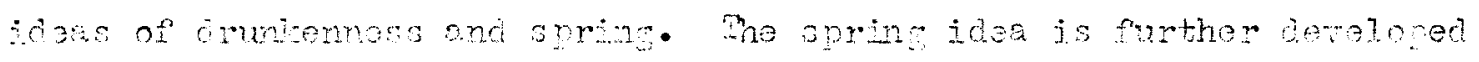
Sn the wlustoms to Bastor and the "jubilant mas." It will bo noted

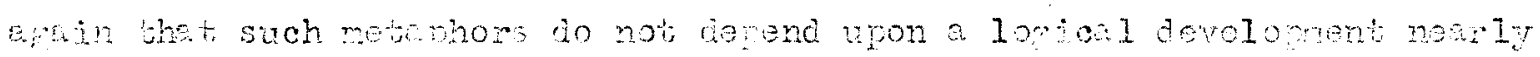
so mich as wn the rowerul conomtration of comotation of lore, sprin and dmutenmas within the conted of we noom.

me newous temo of the wholo poom is ruth strosisa in al-

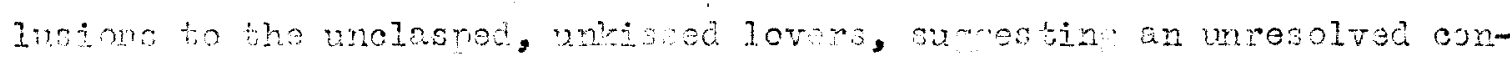
flict, and se the root asis:

Try ahonit two lovers o frozan asundor in fear?

A similar feelinm is evoled by the "shredine of an hriz blosson" where

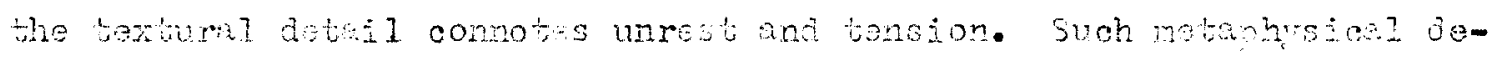
vioes as paralo and antithesis are olso utilized to advantage in suanting tie same noor.

"Speotral Lovers," "Iameless Song" and other moker notaphesion. poens revel how a poet inay create vache peelin of nood and atnosnhore

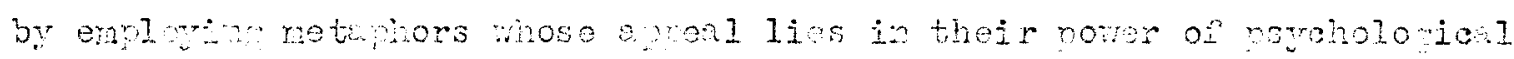




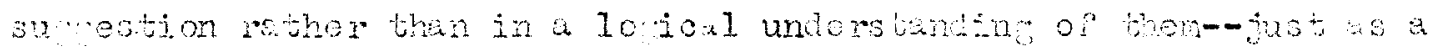
pianiot ney nore quidy commionte a sonse of mood with a shimerino arpouio than with an intricnto fune.

A. second runction of the aycholo ios netarhor in nodern motaphrston torse is to exmes; a subto experience-ns thou th throun a

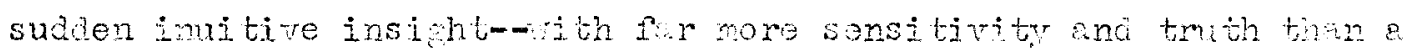

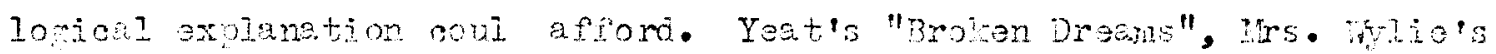

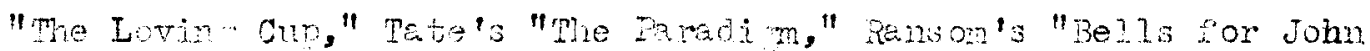
Whitosido's Dav ltar" and othe noderr poons shom an intarest in the twosmont of a snocific reletionshin, a specific experience and a snecisic time-a concem nartionlerly chsucteristio of modern vase. This tendency of modern pots to pous beir view more closely has led mosi of the twentioth century motmphrsicals to emplo metaphor with delickiz psycholoniogl ovatonas to ive a nore sensitive, more subjoctive acount of an experience. Lesthetto ains of this rinc are weII achieved in a poem such is 21 iot" "Hosteria:"

is she lauhed I wh aware of bocoming involved in hor laurhtor and bein a pert of it, whil hor teath vere only acoidental sters with a calent for quadrille. I we dram in by short rasps, inhaled at each monentary rocovory, lost finally in the derk cavemo of her throst, brissod by the ripples of unseen masles. An elaerly rator with trenbling hands was harieriy sproding a pink and whis checked cloth over tie rustr roon jrou table, sarine: Ir the lacy ane watben wish to tale

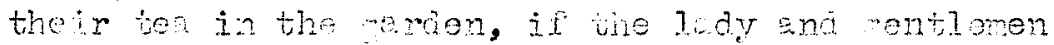
Wish to talo their tea in the aron..." I decided the ' 12 the shekjz" of hor bress ts could be stored, s me or the frapnents or the aiterioon mikh be collooted, and I concentroted attention with careinsubtoly bo this ent. 
It is the intenst and inediagr of an experience, ratier than its

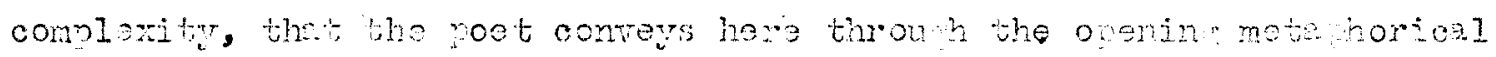

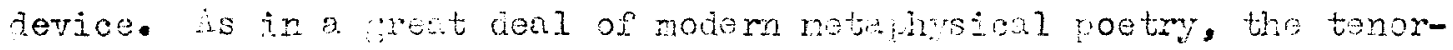
vehicle relction becomes indistinct in the play of psyoholowed oon notstion, but the imure is stricin in its subjectivisn and in the feeling of sympatiny it convers. The poet's sexual-psychologicul concontration on the woman wa her comoelize lauthter is sxpressed in

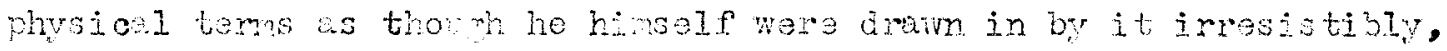

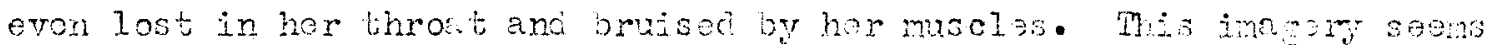
to axpese on the phricel rlane the poet fo feoline of l sine his orm will and identity in the will anci identit of the wanan. His association or the roman's tath with "eccicientul stars with a tal ont for quadrillo" also helps stress the interse conountrion the inores a relationship to time no space.

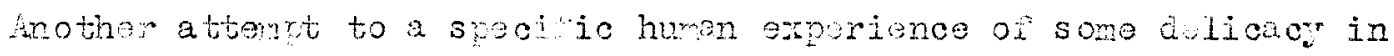
tems ol a metewhor is soen in surent poon XXVI, fron "On this Isjand:"

Thet night when joy bevan

on narrowest veins to push

se hater lor the lash

or morrine's lavellod na.

But morinin: let us rass

Anc der by day relies

Out grew his nervous launh;

Groms credulous of pesce

As nile by mile is seon

To trosnasser'is reproach

tind love's best classes reech

to aiels but are his om.

The retarhor of the trosomssers on love's estates and ther firures ars usen here by the pot, to express an experience of loro in an unsure nodern society: for ludon, probaby mon then an other modern motaphysicals, is concerned with the inesconeble rosiure of modom lite on 


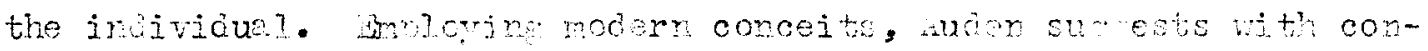

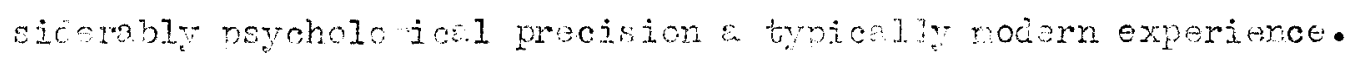
The poen orens with the rich finre of the flushir. of the veine,

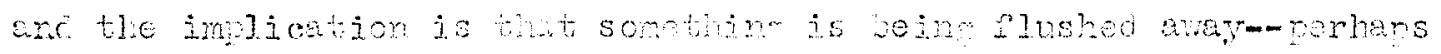

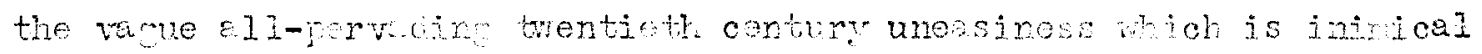
to lcte.

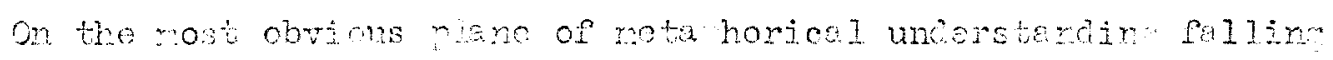
in love is comred ith discoverin rew lande, as in Dowe's "To IIs

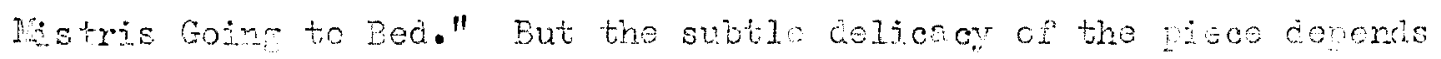
wor an ecnation of the feer that atends the ect of tressessing on another's property--an ect mich tyripiss the phoical restroints of

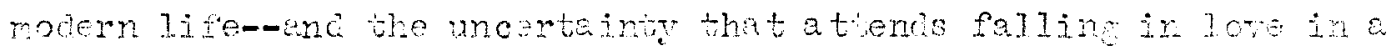

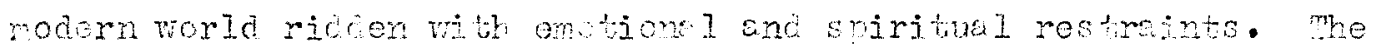

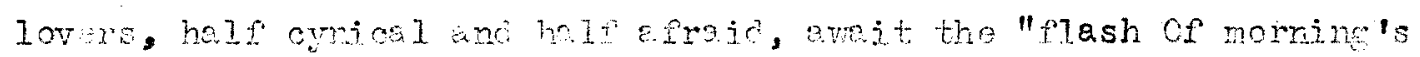
levelled un." They jue a "nervons lau h" after safely paosing the first hazerd, und sinelly they row "cr dulons of poes"-prerbars too moculous.

The rucess of these pieces depends in lawe mosure unon the precision with whoh the netaphors exrreso in an artisic entity the flow and intensity of the mind in actuen emerionce. This tre of subSective, psycholonesi netanhor--eo closely associeted with the rinciple of emontry, as in "Horsteria," -- is of course in hich contrast to the

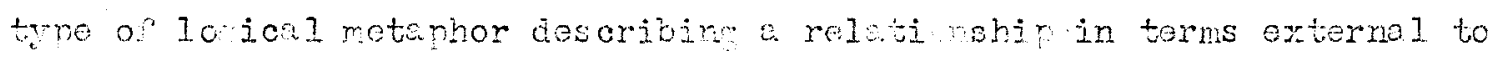

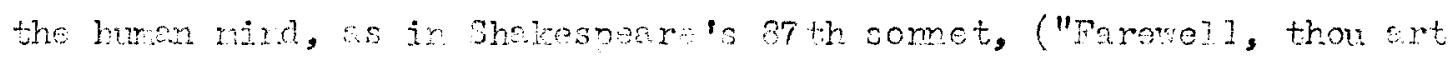
too den for my possessin.") 
$\therefore$ thirc rery importent and distirctly rodom function of

twentioth contum metephrsical motaghom ja to convor atiric or ironic

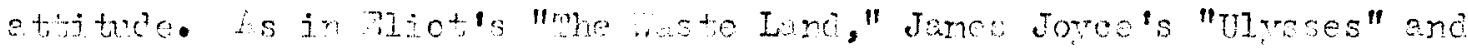

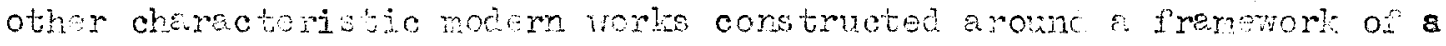
so-cenled nobler eve, comn retive structure? devices mat be used to

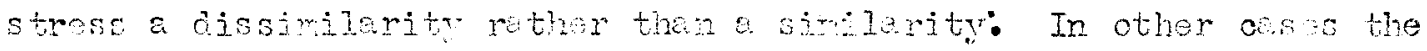
satire may be more obvicus no airect. This crish setire, of en alfinclusive in reture, is a distinct cheracoristio of modrry metaThesicol vrso, and aprerenty indicetes an intellectual revolt a ninst: nineteenth century ositivisn ano optinisr. It will be discussec more fully ir the next chater. in incenious, vom deft use of this elenent is found in Renson's "Good Sh:ns:"

Fleet shirs encounderine on the riwh sess who s pek

These hailed each other, poised on the loud sure of one of liss. Grurcy's Tuessay toss, Nor trimred one sail to baflue the dririn breeze. i maciroon absorbed hor emotion; Iis hue was eshy, but an efrect of ocean; The erchaned the neutical techicalitios.

It wes only a noting or so, anc thes they puted; what they sailed, most eertinly bound for port, So semorthy, one folt they covid rot sink; Still there was e tremor shook bhem, I should thint-Beaudiful timbers it fon stomy srort And into miserly merchent hulks convertad.

Ransom uses the olo "shirs that raus in the nicht" metaphor here ir a way thet probably seldon, if er $r$, ocurred to the serenteonth century meterhysical poets, and yet the cevice he mpors is fully as oolo and ommlar as ant seventeonth century fimre. The roet's sitirical use of the netarhor in this sonnet is rarticnlarly interestirg becuse he 
nales it serve the double purpose of pointine out simnitanecusly a similarity and a dissinilarjty in the relatimshio of the loters end the shios, while seemire only to indicte the similarity. The comrarison is cbvicus end conventional and has been dereloned many times, nsuelly with such a sentimertal aproach as it foum, for erample, ir Bectrice Forreren's Shins that Fess in the Wisht. But the deliohtful satire-ond the very crux of the foen lies in the dissimilarity between the bold shjus bratine the hith sees and the lifeless, tirorous covnle, these conld-ie lovers which are so renresentutive of the decadent Southem society of wich they are a part. Only one othor finre irterrurts the extension of the shir conceit as in a tyrical compressed, conrotetive metephor Pinson remarks:

\section{4. lacaroon absorbed all her motion.}

This dert satiricel touch is nerticularly effective not only becuse it describes so reatly the qualjty and quantity of the ludy's emotion, but becaxe it also sucosts her busily nibbling a macaroon over her tea, takin refue from the litule enoworel crisis by tuming to a Iemiliar gettiness.

In "Vinter Remembered," a self-sativicel Ranson poem teoring with a matapheicel complexity, the poet closely identifies the effect of hin of his mistress's absence and the numbin cold of winter, elabortin unon the metaphor with a nice delicacy. The five stanza poem concludes:

Dear love, those fineers that had inown your touch, ind tied our seperate forces first tomether, Were ten poor idiot fing rs not worth much, Ten frozen narsnios henine in the weather.

It. is cherecteristic of Renson's style than in these closin: selfsatirical lines, where the language aprears nost "unnoetic" anci a litule 
ridiculons, he is really mast tender and serious. Acin the firure is of course comrately illo ical, but its use in the contert of the foem convers to the reacer's nind a cirite sumestion of sirorre, deenly-relt huility

a sonewht sirilar use of in self-imclusive satire deroloped

throveh a Iundamentally connotutive metahor is seen in Yeats's

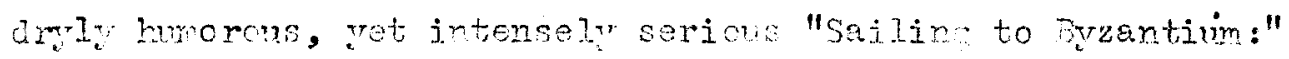

Thet is no country for olc. men. The youns

In one arother's ams, Dircis in the trees,

-- Those dying cenerations--at their song,

The selmon-falls, the mackerel-crowded seas,

Fish, ilesh, or forl, comend all sumer lone

Whateror is berotien, born, unci dies.

Cavint in that sensua? misic all noglect

Iomments of une eine intellect.

\section{II}

An aged man is but a paltry thirs.

it tatiered coat unon a stick, mless

sovl clan its hands and sin., louder sine

Por ever tatior in its morti 1 dress,

Nor is there singire schon? but studyine

Iomuen of its on manjicticer;

And therefore I have sailed the seas anc cone

To the holy city of Byzantium.

Continuin this self-inclusive ironic attibuce in the remeinin" two stanzis, the post asks that the holy saros of gyantiun be the "singinenasters" of his soul, and that he be ethered "into the artifice of eterity." In conclusion be further elaboretes won his cesire for unchenin artic bic and intellectual forms.

It is aprerent thet the metaphors of the second stanze are imortant not because of thejr Jomic or aptness, but rather becanse ol their wry humorcus, ironjc connotetions. 
This is seou as the arin poet likens himseli to "a tattered coat upon a stick", and speks of his soul cla ing its hands, taking music lessons and strayine "monwents of its own manificenee." The metophors are enoloyec to enbody deen, keen realization of deficiencies tomether with a guite netural pricie. The introcuction of the symbol of Grantium into the piece js of course an outworth of nireteenth century WnIish and Trench pretice rathor than the serentocrth century metarhysical strle.

$\therefore$ ein in $" / \mathrm{s}$ coat", Yeats ives a caustic, satiric trist to a netaphor that is somevhet reminiscent of Mrs. Mile's "A Dec Carpet for Shelley:"

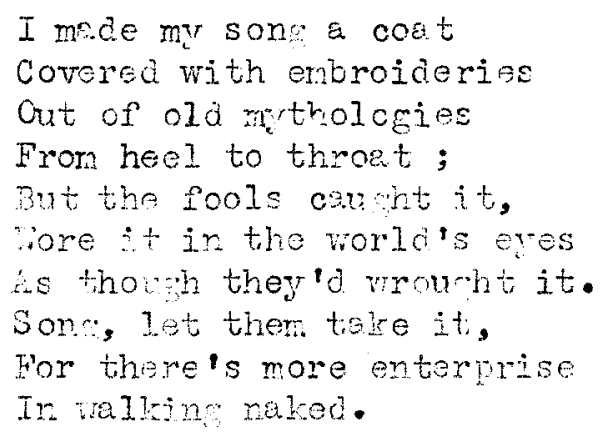


of "the lair's quincy" and the "coward's stance." And Tate in "The Paradigm," quoted in tho last chapter, remarked that the hate of the former lovess who now freeze the air with their ill-feeling is an "ignorant paradigm", inferring that the pair are like ignorant pupils who, declining and conjugating erronecusly, make mistakes that must not be taken too sericusly.

Other metaphysical devices such as paradox, antithesis and wordplay, show a line of development closely paralleling that of metaphor. These figures are used much less frequently in the twentieth century than in the seventeenth, but again the stylistic changes in the modern devices indicate a shift from a logical to a more psychological viewpoint as, for instance, in a tendency for the older antithesis to be supplanted by a new type of antithesis which depends for its effect upon contrasts of mood rather than logical justaposition. .

This can be seen clearly in comparing some of the verse of Donne and Crashaw with that of modern metaphysical poets. In a few lines, for example, from Donne's "Good Friday, 1613, "Riding Westward," there is found a powerful, concentrated use of antithesis, paradox and the pun in which the devices are employed with strict logic to accentuate the intellectual and emotional content of the passage.

Hence is't, that I am carryed towards the West This day, when my soules forme bends toward the East. There I should see a Sun, by rising set, And by that setting endlesse day beget.

Or again the luminous contrasts of "Crucifying," one of seven sonnets in Donne's "Ia Corona" sequence in which some of the poet's most beautiful and striking metaphysical word-play is found. 


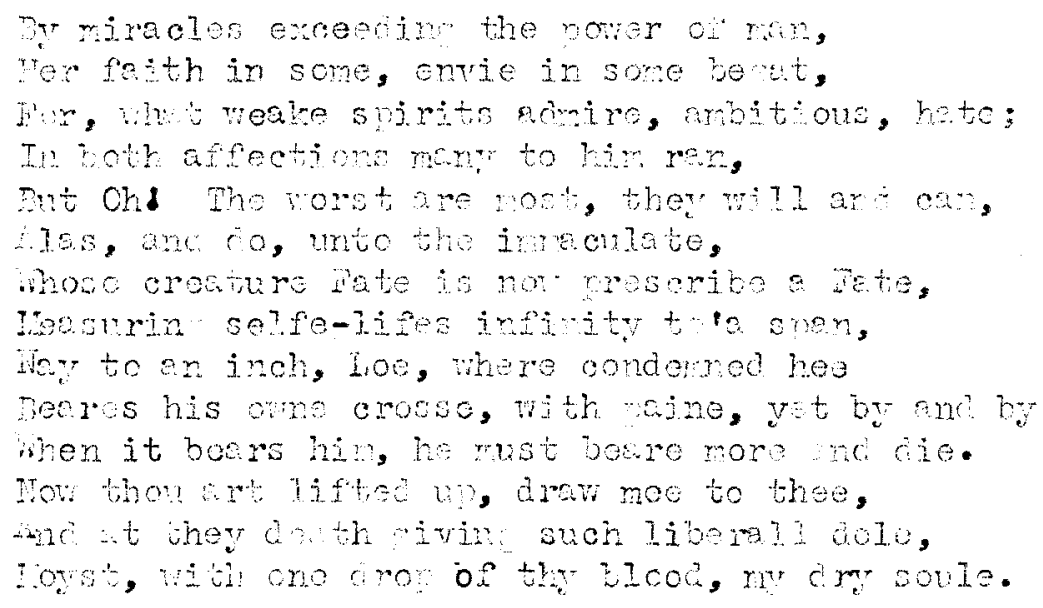

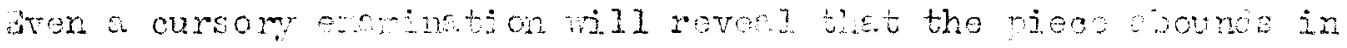

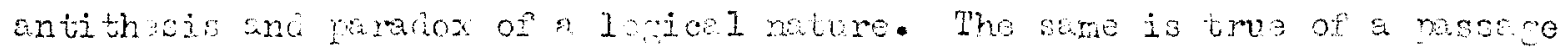

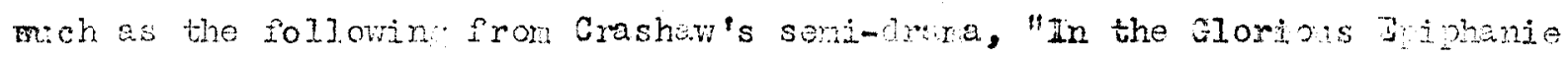

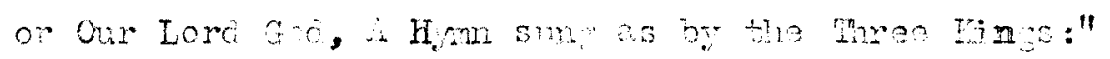

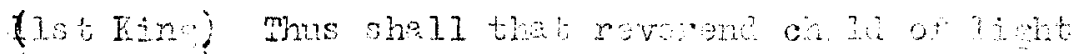

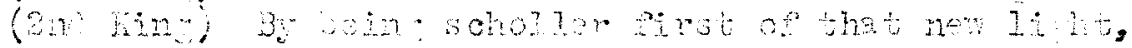

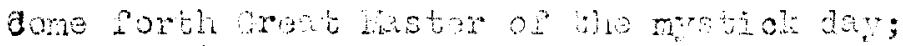

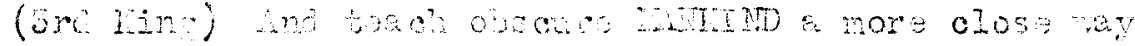

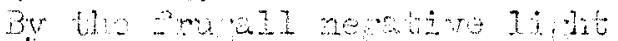

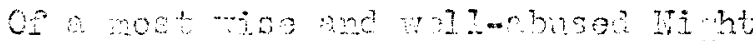

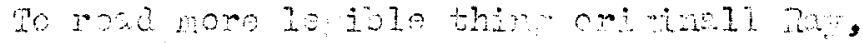

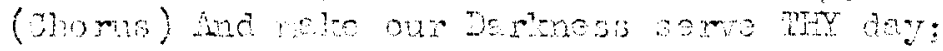

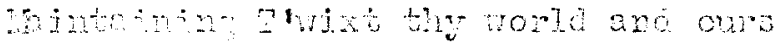

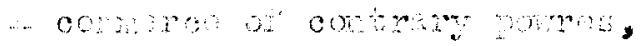

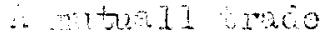

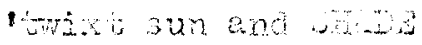

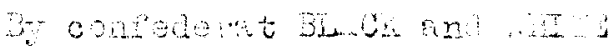

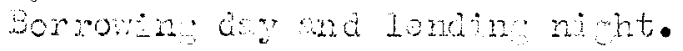

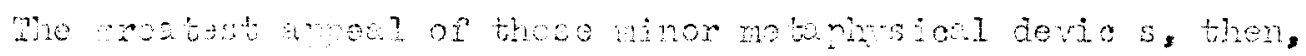

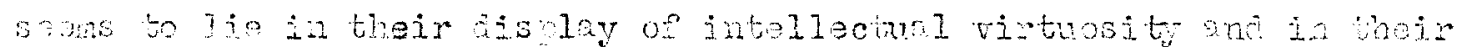

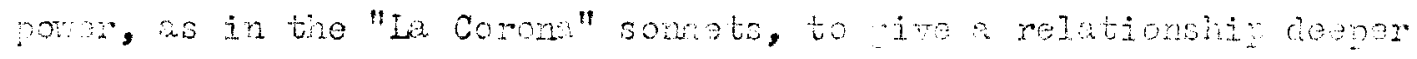

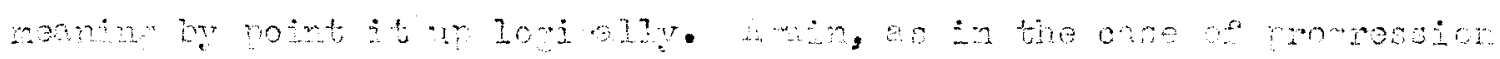

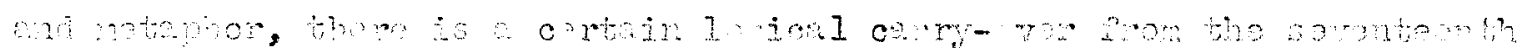

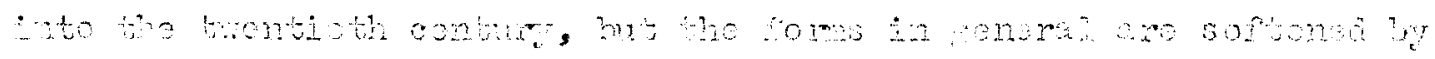

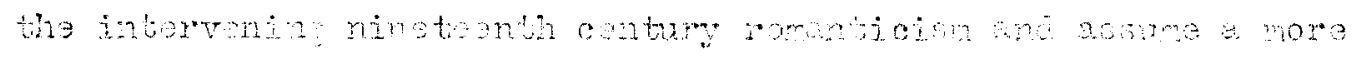
nsyoholorian asto 


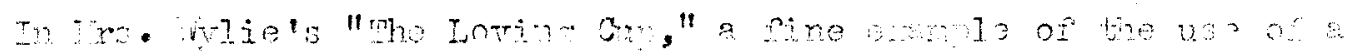

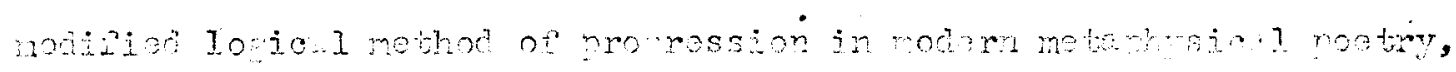

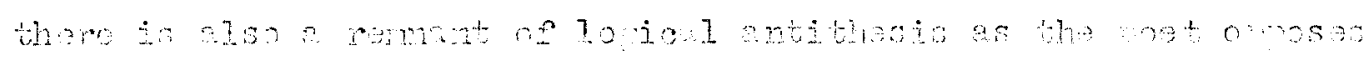

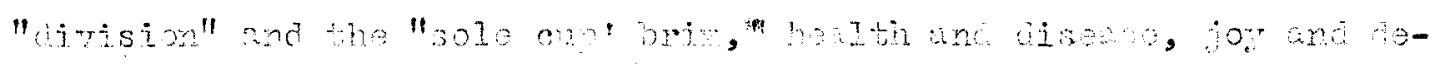

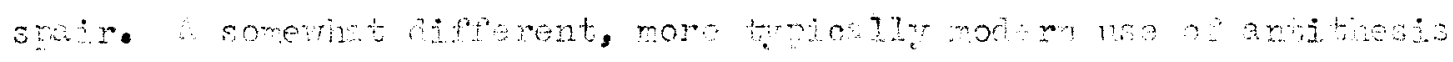

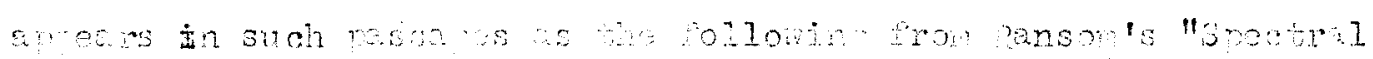
$1.07 \cdot 3: 1$

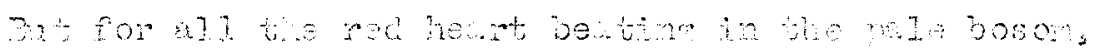

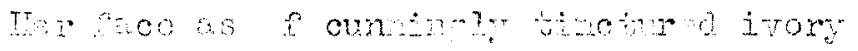

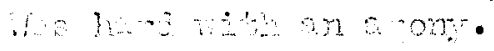

Orans

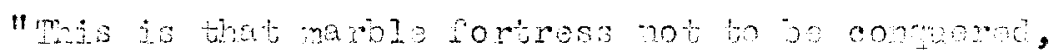

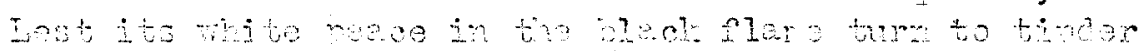
an an ninterbie cindor."

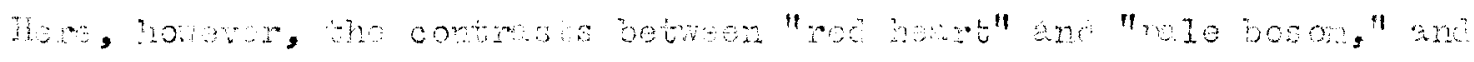

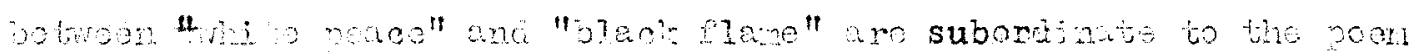
wa a wole those izur is are not the nost outstenting feature of a noon, s.5 in the asso with a rest denl of semententh century meta-

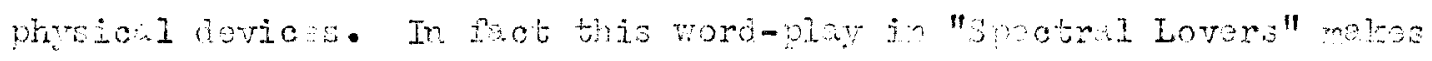

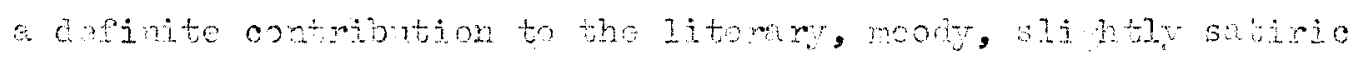

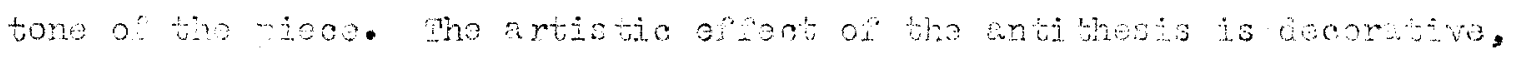

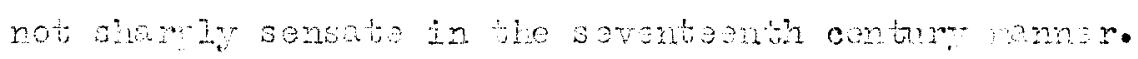

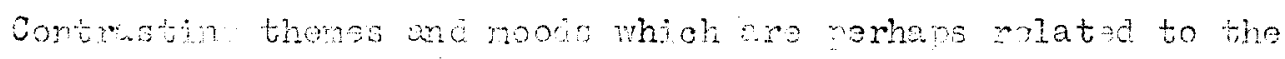

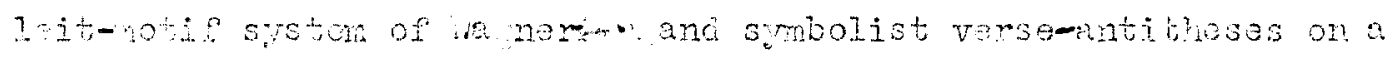

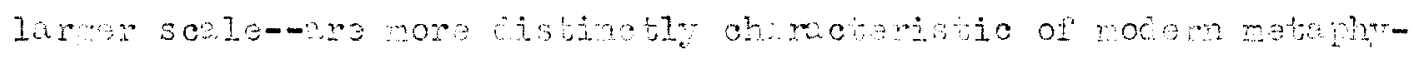

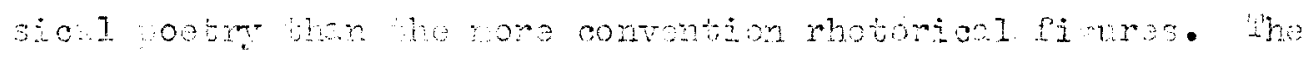

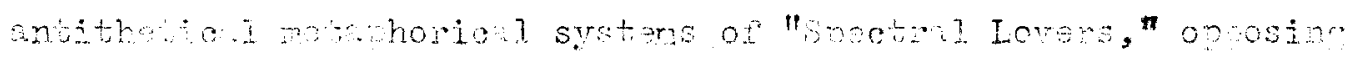

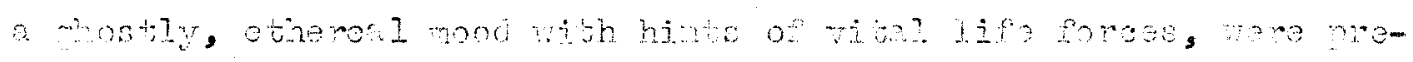

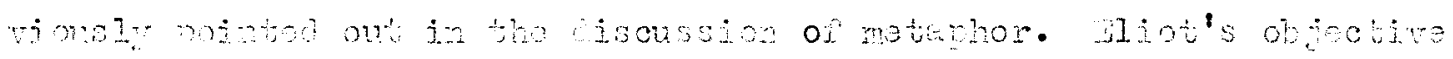




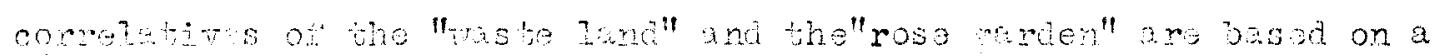
similar contastin" pattorn whoh extends thround his wor.

Lnother hi-hly sonsurus, comotitive use of contristin

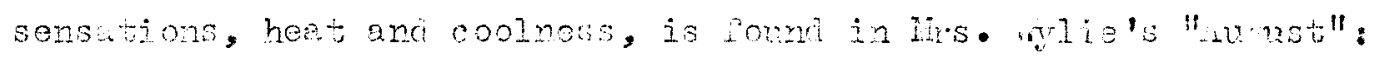

Why onuid tis incro knolentit stride

Dom the red noonay on smin notoelese font?

Pilod in his baruor, tamier thon heat,

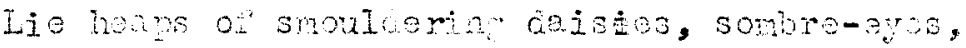

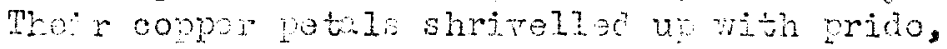

Fot with a suremilit of hett,

Like a cros bramer bone alon, the strest

By ca tivo loopards, black und numine nied.

Lre the no water-litins, snooth as crom,

wth lone stems rivinine crucol? 're there nono

Lice those white lilies, luminous and cool,

Flucheri fron some hom lock-durined northem

strock

37 Rair-haired swinem, divin whes the sun

searoo wams the wurface of he doepost rool?

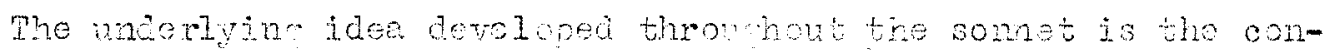

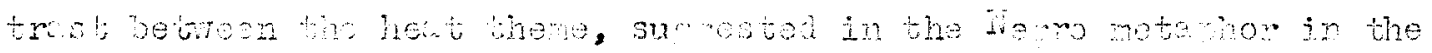
ootet, and the coolness thene, dereloned in the rathar va conotetre

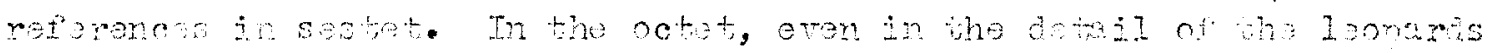

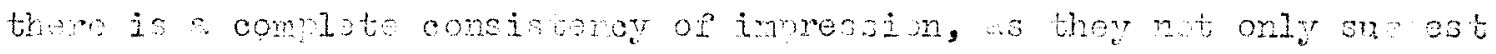

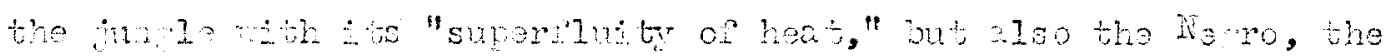

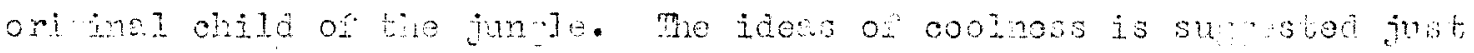
as viridy and sonstively in the sostat. The pot snows of "water

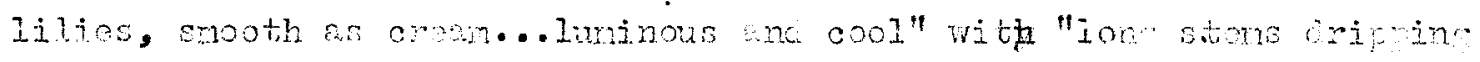

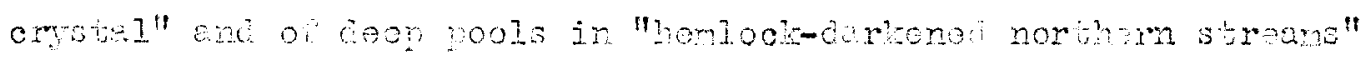

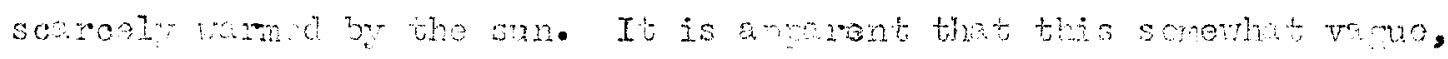

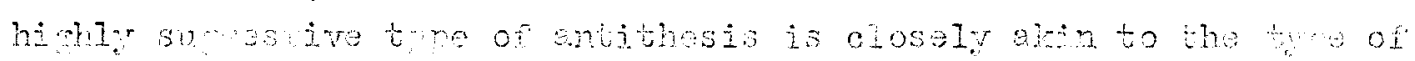

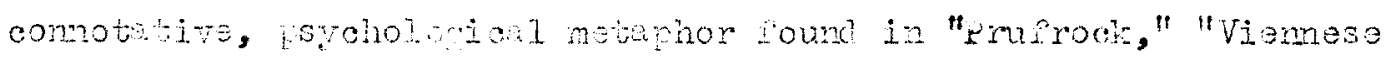

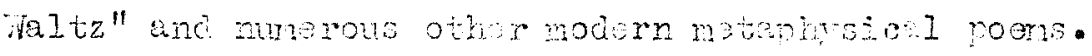




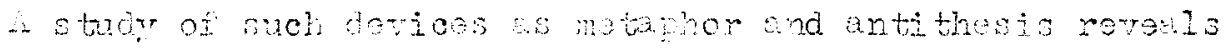

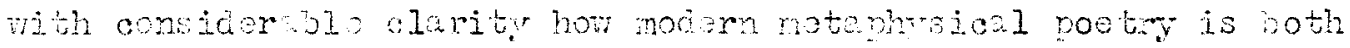

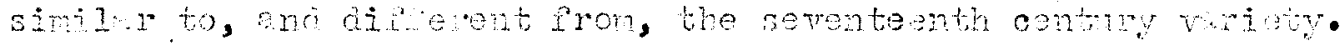

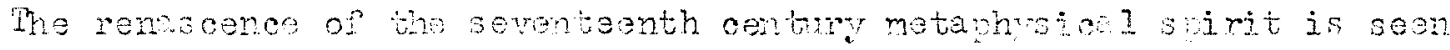

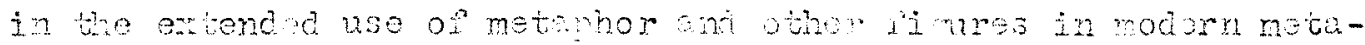

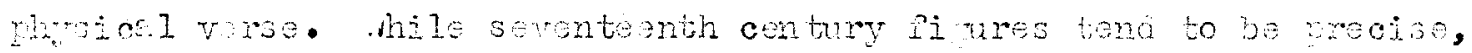
shem ane Lomian, as in Ferbont" "arantse" and Done": "La Corone" somets, and we rundamentaliy exterior to the workin of tha nimo,

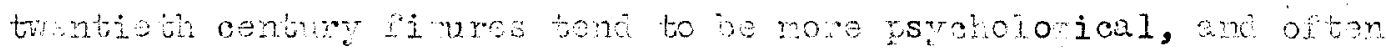

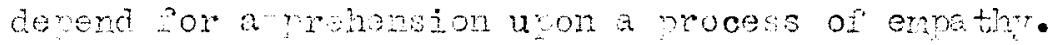

theso modom devicos, which shom the influence of a romito

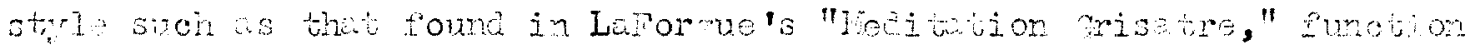

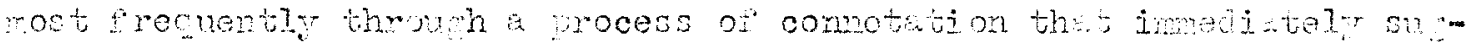
weots to the mire certain subtle moods, somloz exreriances on ironid

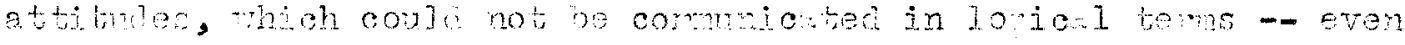

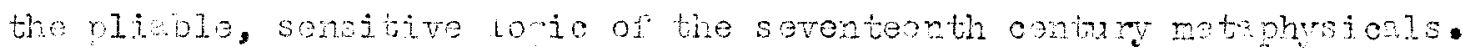


CHAPTER IV

THE TREATMENT OF EXPERIENCE 


\section{CEAPTFR IV: THE TREATMENT OF FXPERIFINCE}

The basic raison dietre for good noetry is probably the expression of some type of human experience. In the last two chapters, treating poetic progression and metaphysical devices, I examined poetic elements which are a vital, organic port of this expression. In this chapter I shall corsider the characteristics of the treatnent of human experience in seventeenth and twentieth century metaphysicel poetry. A poet must almost inevitably treat experience from sone special approach, some particular "angle." I am interested in finding what aspects of an experience--its dominant emotional structure, its conflicts, or its connotativo overtones-are emphasized. I wish to show whether the poet is concernod with presonting frankly the complexity of an experience or with concentrating on a selectirs facet of the vast and varied material of experience.

Briefly, metaphysical poets from Shakcspeare, the anorous sonneteer, to Auden, the ardent leftist, have tended tc write with a complexity and sense for subtle contradictions that testified to their mature grasp of human experience in its many-sided aspects. In the work of these poets there is uscially a fusion of the intellectual and the emotional, the "poetic" and the "unpoetic," approbation and satire. There is a full realization that there are usually at least two possibilities, two ways of life, two ways of viewing a relationship or an experience. There is often, particularly in the verse of the modern metaphrsicals, a selfcriticism. It nust of course be noted that such a complex, interrated mode of expression is not a quality possessed exclusively by the metaphysical poets, although it is characteristic of their rork in both the 
sovanteonth anc trentieth centurias. Uther schools, such as the neoclassic, romantic or ijotorian, have carried to a high pinnacle or periection a partionler aspect of ernorionce, sucl as the cortempletion

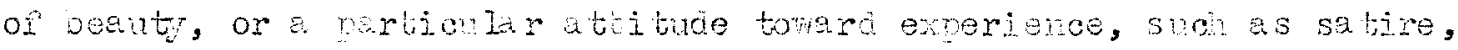

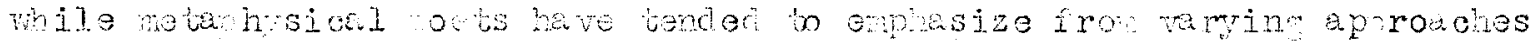
the conclexity andinner contridiotions of expriance.

in element of tonsion, rown. rom an oprosition of wit and

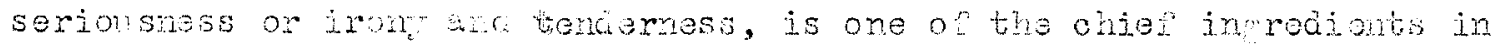

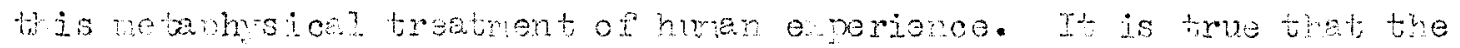

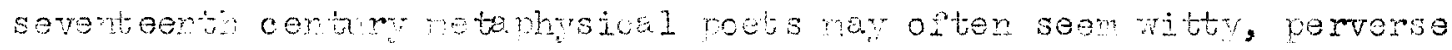
and abstruse tor the rere sake of beins so, but on a closer eramination the antitheses, the parabicol rutiocinetion, the neteromenons etaphors and the "mootic" iaton will be seon to asgist in expressing

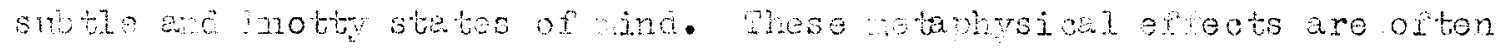
Dbaner by sotine ae inteilect amanst the emotions, as in sone of bhakespare's wot sonnets, or by setine one emotion arainst anoticer.

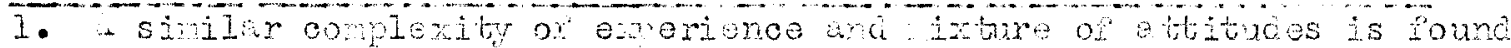

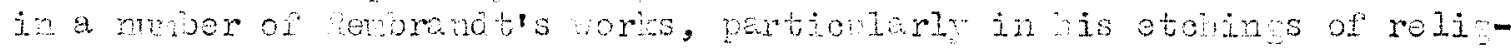

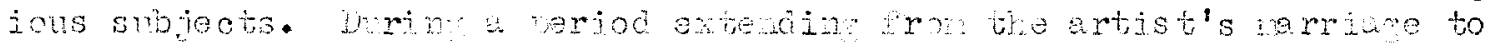

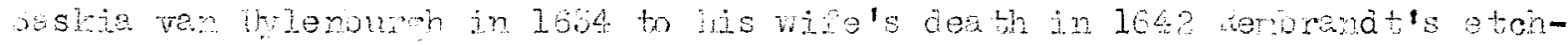

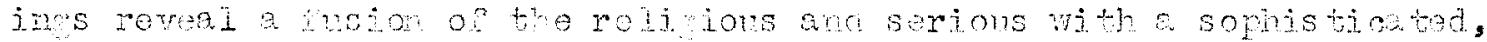
towne-in-cheol iron the freguenty setirizes the ropiler concention

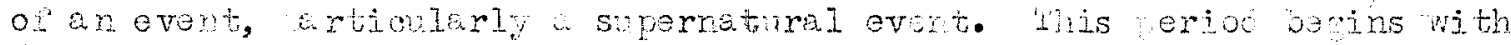

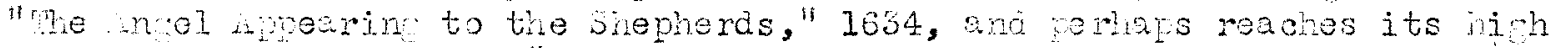
point with "Saan and itre," 1030. Uther etchings showin" these ratner meta-

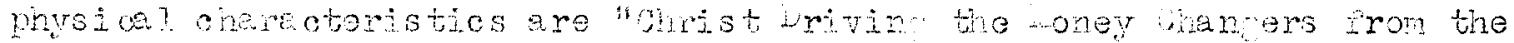

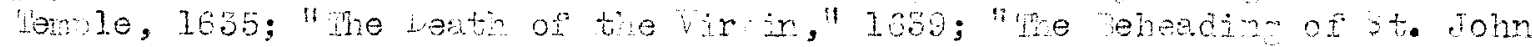

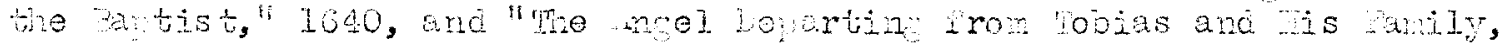

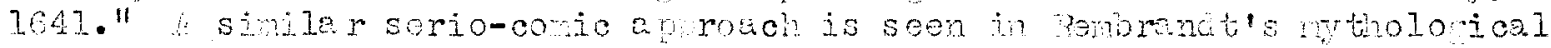

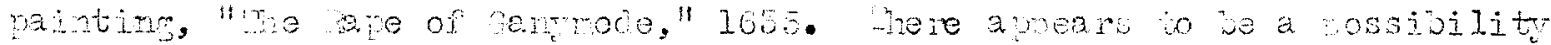

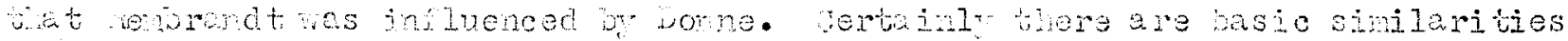

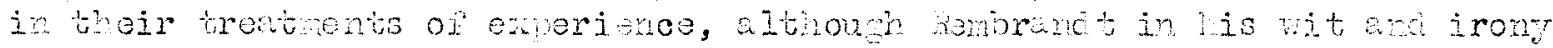
ws we rational ad odern-miod than Dome. It is also knom tret ir

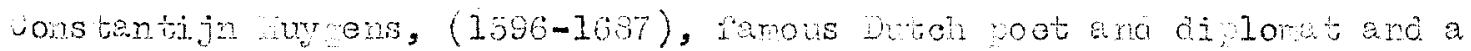
close priend of poms, transiated any of uonne's poens into Tutoh. Fis transiation of the ine ish poet's verse is so osed to have apreared in

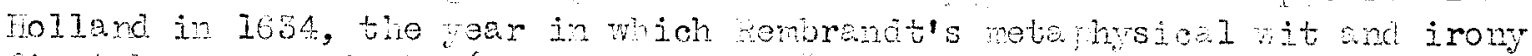

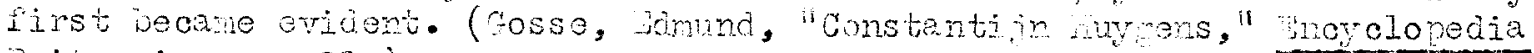
Drtannice, p. 22.) 
This is true oj a creat ceei of notanyscal potr secense in a zare neebre it is a poetry of ental strugle, of intellectul, emotional,

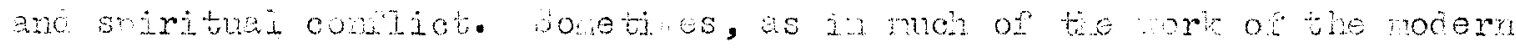

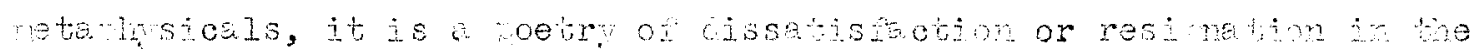

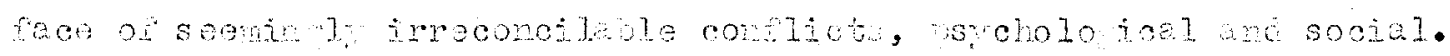

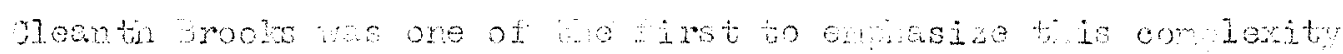

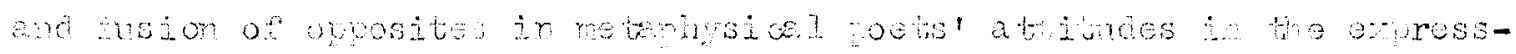

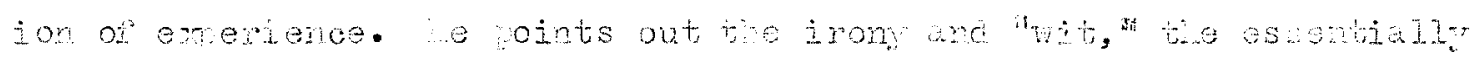

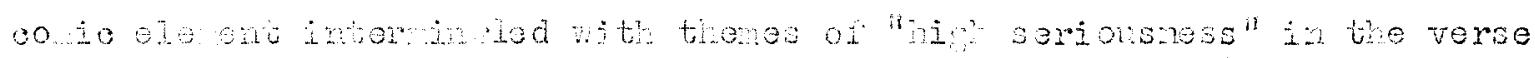

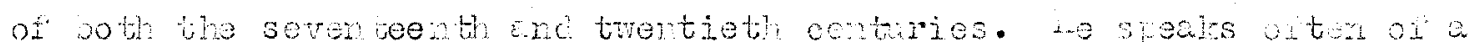

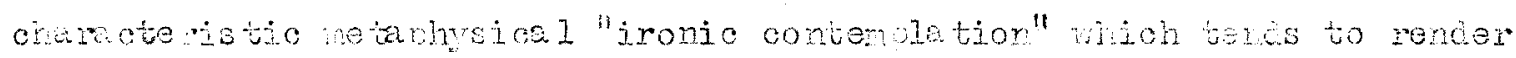
a oen imervions to the destruture crivicion of a jiscrent, nore

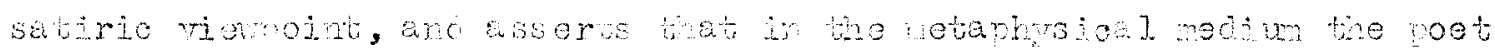
cones rearer than in most verse to emresan his emenience as somplex

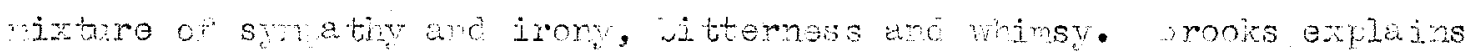

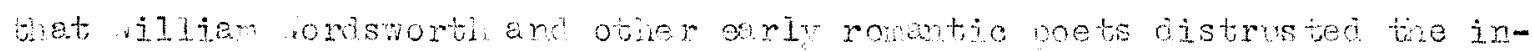

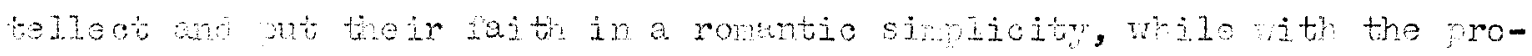
press of scionce in the nheteenth dentur Lora Temys on and otiers felt the oet should oller opirical solutions and inspiratural messares, ans should not lay with wtb indes or indule in an irony indicativo of an evaronoss of the posidie inadeukcy of the solution or the inspiratimal messace. 1

Liot refers to rixch the sane vulitios of netaphroical poetry when

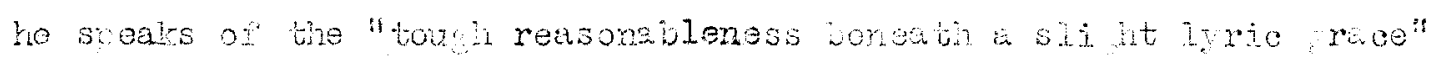

\footnotetext{
1. roos, cieanti, ooem zotro and the radition, np. 3-35;236-30
} 
characteristic of the verse of Harvel1. In a very oft-quoted passagewhich is probably worth quoting again--Eliot elaborates in a slightly different approach upon this same metapiysical concern for the complexity of experience:

When a poet's mind is perfectly equipped for its
work, it is constantly amal arating disparate ex-
perience; the ordinary man's experience is chao-
tic, irregular, fragmentary the latter falls in
love, or reads Spinoza, and these two experiences
have nothing to do with each other, or with the
noise of the typewriter or the smell of cooking;
in the mind of the poet these experiences are al-
ways forming new wholes.

It is probably the freshness, the frankness, and the completeness of these "new wholes" that concerns Eliot most as poet and critic. Declaring that poets should be simultaneously both great psychologists and reat masters of diction, he explains thoy must look into the cerebral cortex, the nervous system, and the digestive tracts, and then form a precise and sharply comunicable verbal pattern projecting their experience. 3

Occasionally in metaphysical verse there are indications of a belief in this more complex view of life. In "Of the Proress of the Soule" Donne writes of Elizabeth Drury:

We understood

Her by her sight; her pure and eloquent blood Spoke in her cheeks, and so distinctly wrought That one right almost say her body thought.

Again in Yeats' "Crazy Jane Talks Vith the Bishop;"

Tair and foul are near of kin, And fair needs foul;" I cried.

1. Eliot, T.S., Selected Essays, pp. 252

2. Ibid., $\mathrm{p} \cdot 247$

3. Ibid., pp. 249-50 
The piece continues:

'A wonan can be proud and stiff

ihen on love intent;

But Lore has pitched his mansion in

the place of excrement;

Tor nothing can be sole or whole

That has not been rent.?

A similar serio-comic tone is expressed in Mrs. Nylie's "Let No

Charitable Hope."

Now let no charitable hope

Confuse my mind with images

Of eagle and of antelope:

I ain jn nature none of these.

I was, being human, born alone;

I am, being woman, hard beset;

I live be squeezing from a stone

The little nourishment I get.

In masks outrageous and austere

The years go by in single file;

But none has merited my fear,

And none has quite escaped my smile.

The poet says in substance that life is fondamentally serious, but that its austerity is relieved by a perception of the comic and ironic lurking behind the serious and tragic.

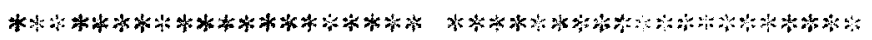

Mile this poetic complexity and sincere endeavor by poets to reveal many aspects of an experience is typical of both seventeenth and twentieth century metaphysical poetry, the treatnent of experience-as should be expected--is fundanentally different. Thile the caterories, "logical" and "psycholomical," are perhaps not literally applicable in this discussion, the significant and distinct characteristics of experiential interpretation in both periods do correspond basically to a logical-psychological polarity. I shall consider these key differences briefly。 
The seviteenth century Io ical approach: in anaiysis or sevenbenth centum retaphoical potro, with an eye to its distinctive

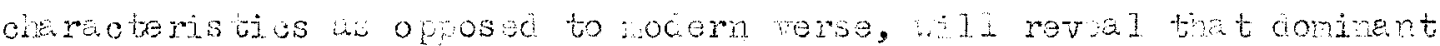

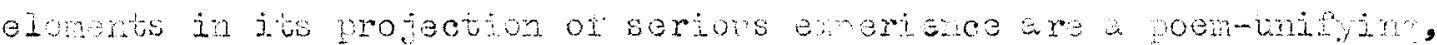

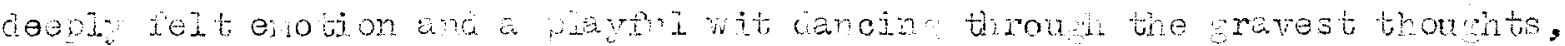
as sem, for instence, in borme's "the jissolution" or herbert's the Artilierie." Aso, ver often the sevententh century oeb will consicer and resolto sone prowan in hmon emerience.

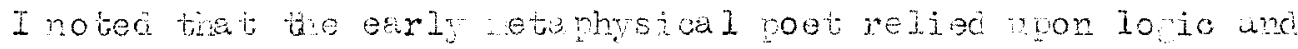
and suln ism in his oetic pro ression ard hetanor. These torms of aproach are also wasio in his treatment of exrerience. In a

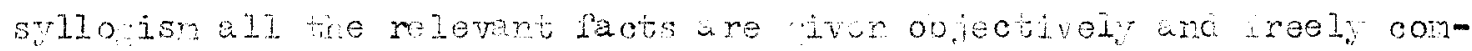

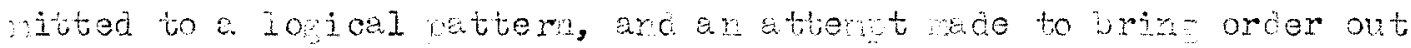
of a roblen throug reason. In a crective a ctine that, ilte the

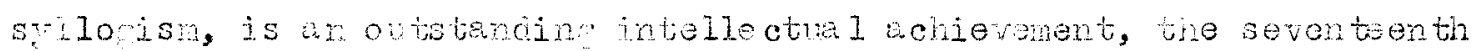

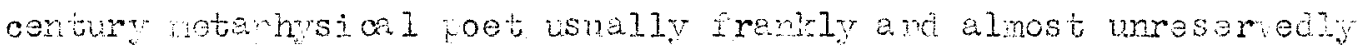
conitits the enotional elonents of is excerince to a lowidal structure, searing to solve his "problen" and to wesolve comletely his enotions

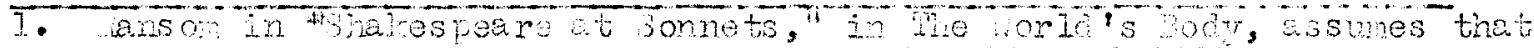

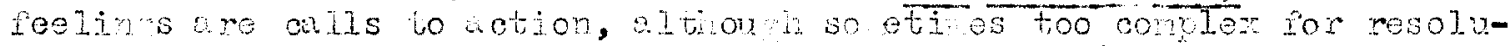

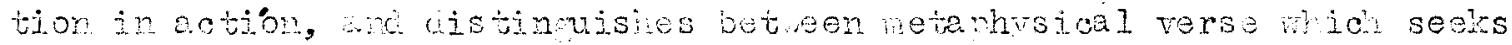

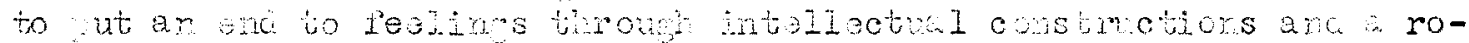
vartic poum, "a half-hataction proicin any restin laces for the

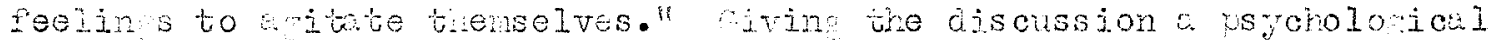
turn, he contrastis vehaviorist (netaphrsical) verso it associationist (ronatic) rootr. (pp. 206-01)

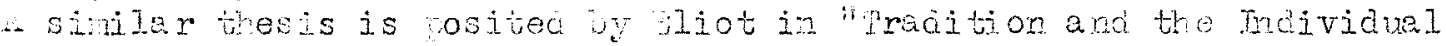

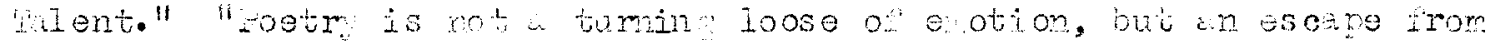
enotion; it is rot the exprssion of personelity, but an escuce trox

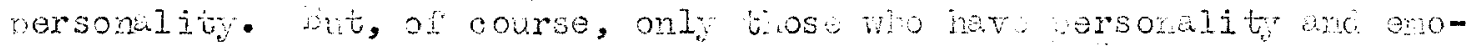
tion now mat it was to want to esche from thom. "leituer kanson nor wiot, iowever, consicer the "belleviorist" wa "associationist" anvroaches in reld tho to the cistin hishin chareteristics of oven-

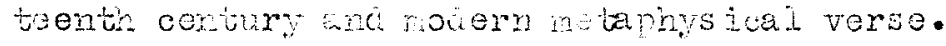


in this way maredly unselronsoious and entirely unabashed in his raturalism or sensulism. Here is tie seme fino of controilea ard

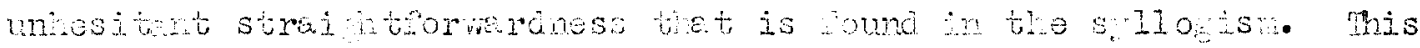

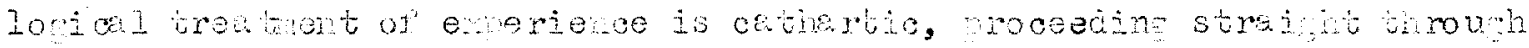

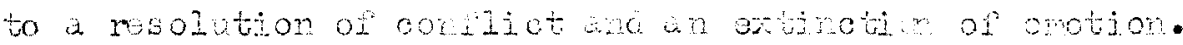

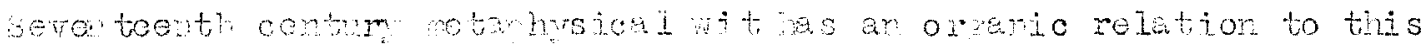

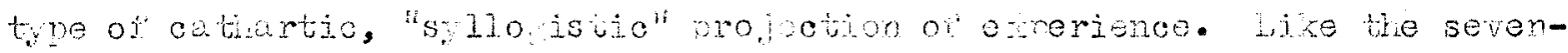

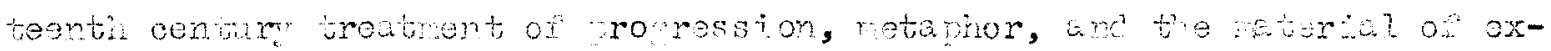

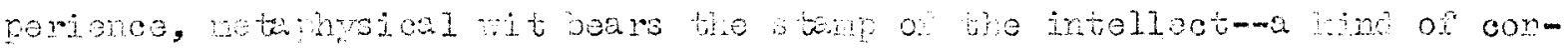

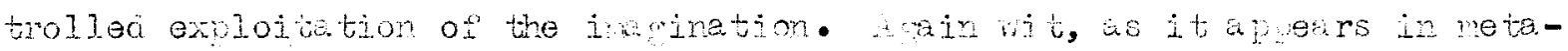
phor, antitiesis, puns and similar tives, is an imortant element in

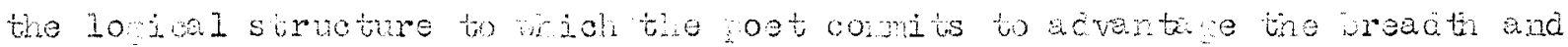

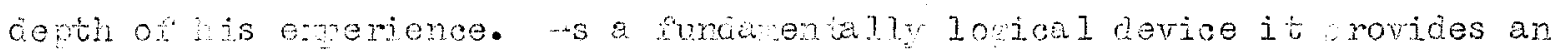

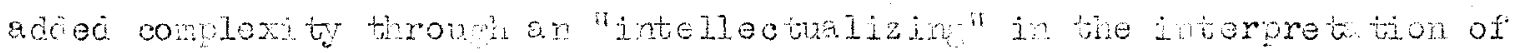

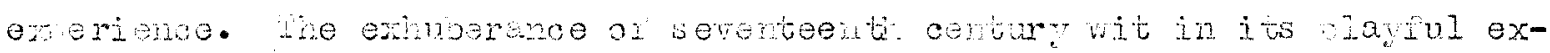
travapnce ark obscurity soens to show a osivive acceptance of ifie similar

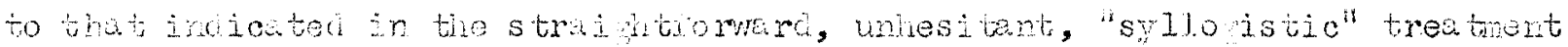
0.6202000

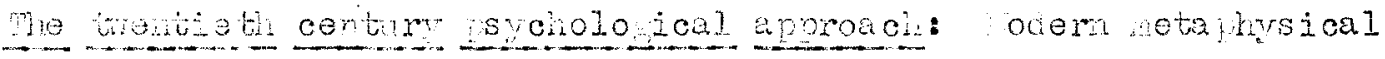

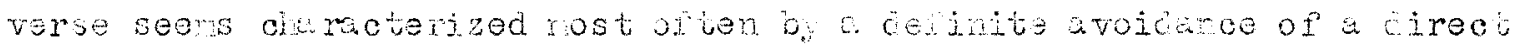

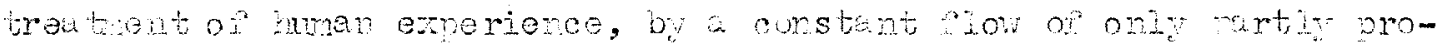
jocted feolines, anc a solf-inolusive newtine iron incicative of a certain de ree of nental armoti and rroertaint. The subtety and comnexit, or an exmerience is roa ized with a mect ceal ot petio rinesse, bu there is seldon serions attemt to resolite a conlict on to urine

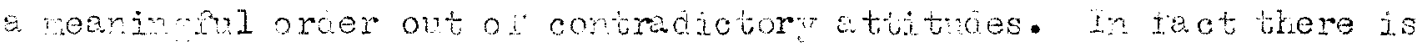

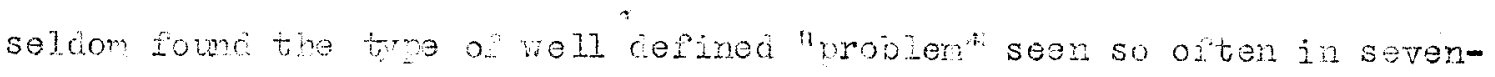
benth century retaphisial verse. 


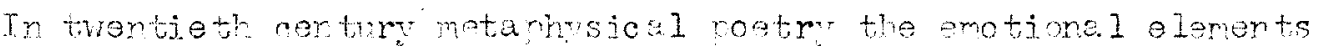
are ore diversified, more scottered, less conentretod in well ce-

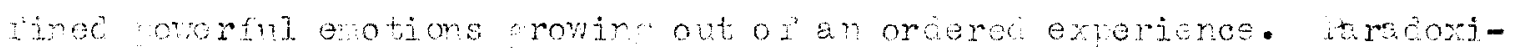

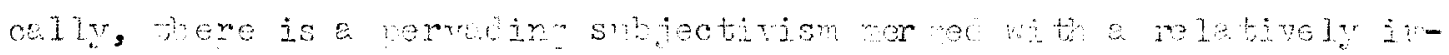

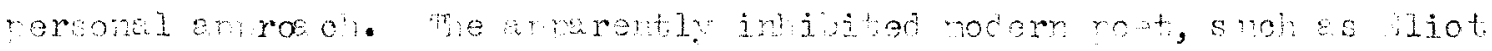

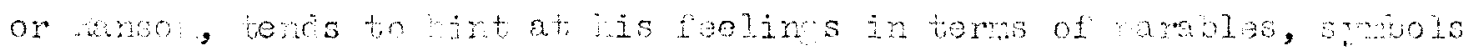

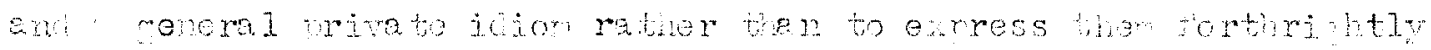

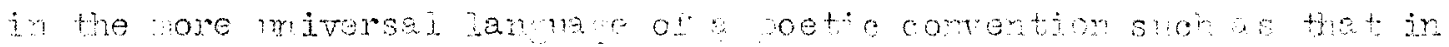

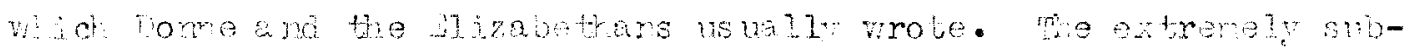

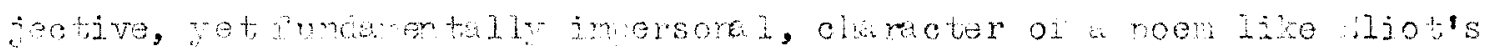
"Mhe abte Isnc" is at once emarent.

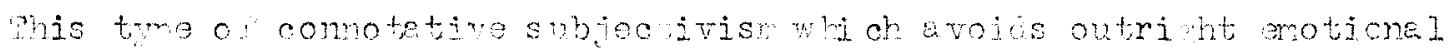
revelution is sed in an increased embats in nodern tota hrojoal rootry on what ay called rood and tone, entiwe intancivios whid are inherent as overtomes and muerourents in nost experionce, ard wioh

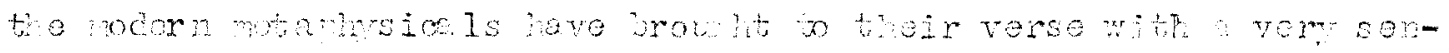

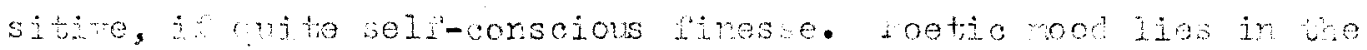
commicktion of the ex ariential mood, or kind at all-remadine emo-

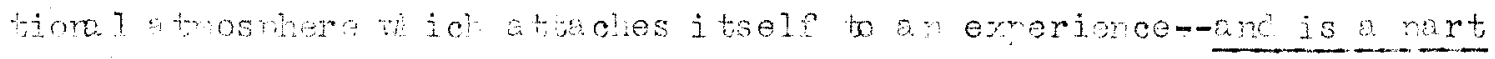

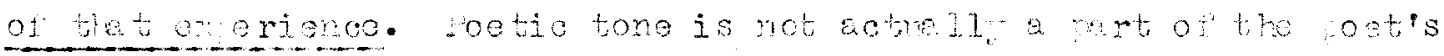

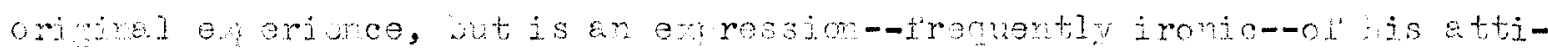

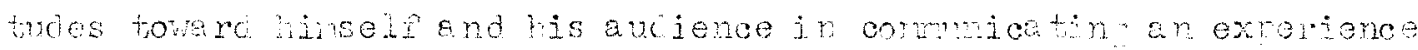
within tre poen. The ook of a roon ma ve thount of as the andire rocuct of the entire oetio situation with its varied textural cetals

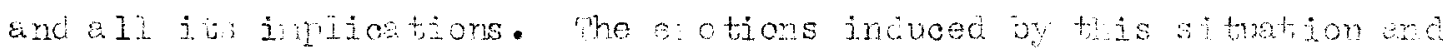
its comotetions rowce a cortain state of minc in tio reader who is better able to jeel hinseli closely jeetilied with the roetio stontion. the function of notic rood is robely primarily a roess of ancthy 
On the other hand, poetic tone seens to crow from the poet's attitudes, as expressed directly or indirectly in the poen, toward the reader and toward the elements of experience being treated in the poem, whether he has a role in the poem or merely seems to approach the poetic material objectively.

Thile a playful wit resenbling that of the serenteenth century sonetimes sparicles against the sualiy sonemlat more somber dress of modern verse, a romantic irony, springing larsely from the work of the rench symbolists and other nineteent century ramentics, is one of the most distinct characteristics of twentieth century metaphysical poetry. As wit seems related organically to the seventeenth century logical structures, this iron seems similar Iy related to twentieth century psychological and romantic forms as it often suggests a nental state of indecision or vacillation, into wich no logical order has been introduced. This odern irony often becones almost synonymous with the rather unstable emotional attitude of the "disillusioned intellectual" of the twontietl century "waste land" who self-pityingly turns in upor himself. While this use of irony adds almost immeasurably to the sensitiveness and completeness of the poet's account, it basically indicates a rejection of life, or perhaps an amused, cynical tolerance of Iife that dalizes with the stuff of human experience.

In brief, metaphysical poetrym-and indeed most poetry--in the seventeenth and twentieth centuries shows an exceptional subtlety and comolexity in its projection of human experience, but tis expression becomes fundamentally different in the positive, boldly emotional, vitty verse of the seventeent centry and in the rather negative, inhibited, subjective and ironic poctry of the odern period. These characteristics may be brouth out nore clearly in an examination of two basically similar poems treating a poet's wooing of his 
mistross, arvell's "To his Coy istross" and Ranson's "Iriunpli" I quote the arvell piece:

Had we but vorld enowh, ard time, Wis coness, it dy, were co crine, .e rould sit com, and bini wion ray To valle, and pess our loto's caj. now the Incian anes' side should'st rubies finc: I oy bie tide of Iuner arid complain. I wo wd Love you ten yes serore tho llood, and you should, if you blesse, reinse lill the conversion of the Jeris; i vogotable love should row Vaster than empires and ore slow; An hundrea vears should eo to pruise Thine eres, anc on tin purchcad zoze; Tro huncired to aciore each oreast, sut tilirt; thousand to tile rest: Ai a co at least to every part, And the last age should show your heart. For, lady, ou deserve tis atete, ov wovid I love at lower rete.

Sut at my jack I alvers heer 'Line's wineo chariot hurr ins rear, -inc vondor all jefore us lie Deserts of vast etemity.

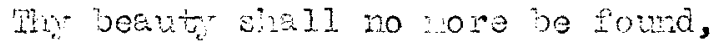
or, in thy arble venit, shall. soma - echoins sote: thon worns shail try that ion preserved vir inits, had our guaint honor turn to dust, Anc' into asses a.l wy lust:

The ravo's a fine and nitrete loco, lit none, I thint, do biore enbraco.

Som theriore, whic the youthul the Si bs or the slin like norrtre dew, fac wile thy willin soul trans ires -t ever poro with instent pres, ow let us sport us mila we ar., fand now, ine a corolis bircis of prey Dther at once our tire devour, whan langish in is slow-chaped power. Let us roll all our sireneti anc all our sweetress on into one jall, Anc tear our pleasures with roun strife, Wrough the iron gates of life;

Thus, thoupt ve cannot rake our sun stanc etili, vet we ill male him ru.

Outside the poetrr of Dome there are lew poons in the anglish languace in wicl provity or wit, and the intellect and the erobions, 
coalesce so successfully as in this piece, and it is easy to find here what Eliot in his essay, "Andrew larvell," alluded to as "tough reasonableness beneath a slight lyric grace."

This "tough reasonableness" is sen in some measure in the strict, syllogistic logic of the poem's organization andprogression. In his premises, the poet tells of his love wich he would like to cultivate and express throurhout the world for all tine, but he hears "lime's winged chariot" and recalls that nothing lies ahead but "deserts of vast eternity." Therefore, he concludes, let us love while we nay and roll all our strength and sweetness "up into one ball." The poet is faced with the "problem" of enjoying the full measure of his abundant love-considering the narror linits of a morlel life span and the coyness of mortal women--and presumably solves the enigna in overconing his mistress's objections in a forcefin appeal to a carpe diem philosophy in the closing stanza.

Indeed the cogent logic of this organizational structure undcubtedIy contributes to the deeply-felt emotional power of the poem and to the compeling conviction of the poet's appeal. A dynemic directness characterizes Harvell's address to his mistress as he refers to a love that takes on heroic proportions as he alludes to all lands and ages, and as he makes a frank plea for sensual pleasure. He mentions unabashed ris own "Iust," and there is an almost rutiless vitality found throughout the last stanza as he spears of the "instant fires" at every pore, of "gmorous biris of prey" devouring time, and pleads for pleasures torn "with rough strife" from the hard, unyielding exigencies of life. Particularly significant is the fact that the pjece ends on a note of optimisn and acceptance as the poet rids hinself of his longings in presenting the forceful logic of his plea and in envisioning a completely 
satisfying amorous triumph. Needless to say, the inhibited modern poet usually does not foresee a similar success.

The intense seriousness of the zoet's appeal is accented by the witty levity and teasing irony in references ta the worms that will destroy "that long preserved virginity" and to the fine privacy of the grave-where none embrace. There is also a certain tongue-in-cheek humor in the allusions to his coy mistress's "willing; soul, " and to his own "Iust." Eore fertile wit is seen in the references to the "vegetoble love," the brilliant metaphors of "Time's winged chariot" and the "ceseris of vast eternity," and the closing conceit on the sun, as well as in the exacerated gallantries of the first stanza. This use of wit and light satire increases the sense of convincing reality conveyed by the piece and provides a broader, more sympathetic basis for comminication.

A quite different, twentieth century culture is seen reflected in a poem about a modern poet-wooer, Ransom's "Triumph."

Athens, a fragile kingdom by the foam, Assumed the stranger's yoke; but then behold how meek Those unbred Caesars grew, who spent their fruits of Rome For ever after, trying to be Greek.

I too shook out my locks like che born royal; For she dissolved in tears and said my barbarous name, And took my oath, she was so piteous and loyal: Vote the young Caesar triumph, spread his fame!

But oh, I find my captive was not caught. It was her empty house that fell before my legions; of where her soul inhabits I have conquered nauht; It is so far from these my Roman regions.

This little poem of exquisite subtlety is constructed around two interlocking psycholcgical metaphors depending much more for their success ipon a delicate web of connotation than upon a logical pattern. Although it is impersonal in tone, it is interesting as one of the few first-person poems witten by kansom. In jescribing his relationship 
with his beloved, the poet deals in his house-occupant metaphor with the philoso hical relation of the body and soul, and again with the historical relationship of Rome and Greece--indeed an am le share of metaphysical intellectualism for one three-stanza love lyric.

There is no attempt to resolve a problen, and if the poet really feels very deeply about t is matter, he is reluctant to express his grief in a very forthright fashion. The piece is not characterized by a convincing deep emotion and a call to action, but by a very sensitive network of subjectivism centering around the contrasting connotations of creece and fome, the poem's mood of rather apathetic resignation, and its tone of self-inclusive irony. The relaticnship between the two lovers is not stated so directly as in "To Iis Coy listress"--but much more complately. As Rome conquered reece and was yet unable to understand the spirit of her art and mores, so here the poet posseases the body of his mistress, but cannot feel that he toxches her soul with his own. She is as Athens, a "fragile kincdom b; the foam," and it is interesting to note the delicate connotations of "foam," as opposed to those of such words as "ocean" or "sea." The poet's Roman occupation is referred to in allusions to the "stranger's yoke," "barbarous name," legions, Caesar, triumph and feme. 'The sol. of is mistress has fled, however, and now occupies a home which he cannot conquer because it is so far from his "Koman regions," so far removed from his less spiritual, less sensitive way of life. Tith a cultivated drawing room taste, the poet seems to dally with his feelings and to leave much unsaid. The reader is impressed by a mood of numb hopelessness suffusing the poet's meditations from the first lines to the end of the piece.

The self-conscious, ironic tone whick contributes a variety and complexity to the texture of the poem is even more apparent. An attitude of tonguemin-cheek good humor is of course found in "To His Coy 
istress," but it becomes a wah ore pronouncea hator in the verso of

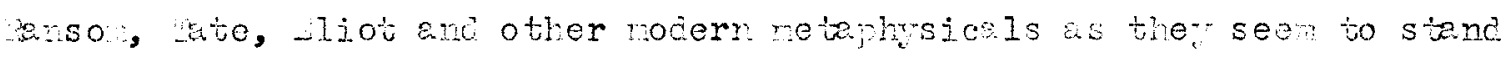

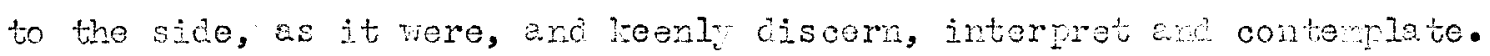
The poetic tone in "primun" is most evident in the poet's ironic, se-

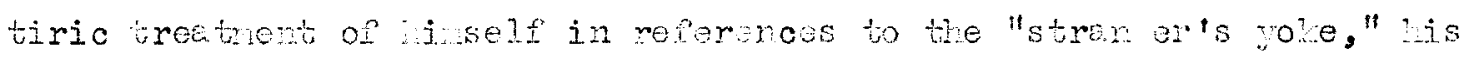

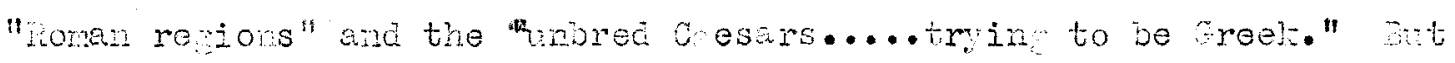
there is also perars the faintest tinse of jrony in his prosentoton

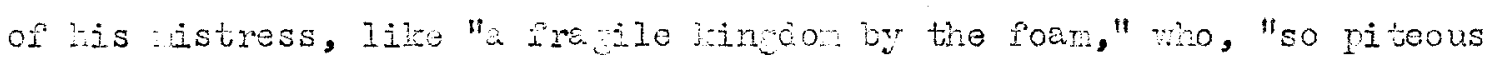
and loyel," wo "dissolred in tears" and seich is "banorous neme." We pot, like a sopidicatec conversationaijst, seen really more concemec with the manner in wich he turns a colished phrase in relating is little tale in terns of a jistoricel parabie tian with a treatLent of we ectual enotional experience.

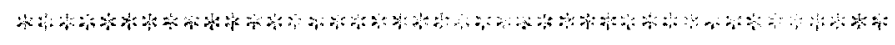

Such comiaxisons jnatoate that the oetic treatrent oi exerience

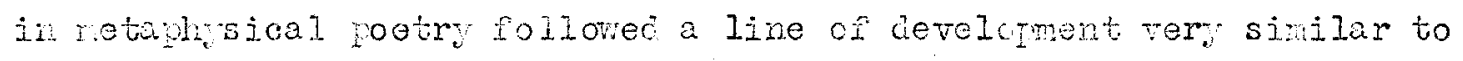
that seon in the transition from lojoel and objective proresion and metahor to psibolocical and subjective forms. In the early seventeenti contur there was a sensitive anc onter introspotive, ret coplex enc robust, treatment of exterience, as in Dome's "A Valediction: To is tane in the "indow." In the neo-clessic veriod enotion vas projected with a rand sweep and sinplicity and an attent was oten made

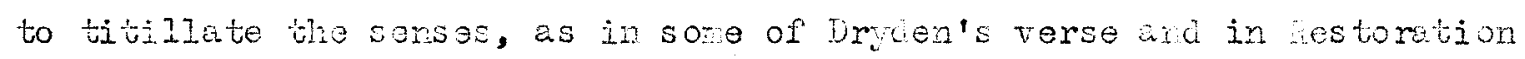

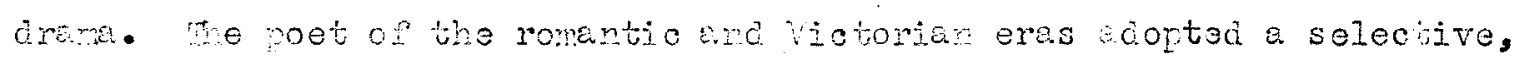
more enclusively "poetic" approach in lis interpretetion of exprence, otten enpasizing with leen insint tho sujective overtones of en 
occasj.m. iocern notahrical verse boasto a creat ceal of the sevenLentl century conceri for the nott complenties of exerience to-

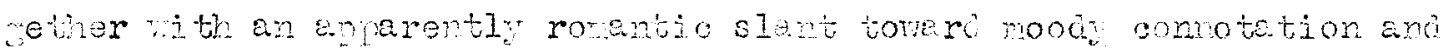
a stiming up of leelin 3 rather than a more diract cothartic appoach proceeding to an aestretic extinction of emotions.

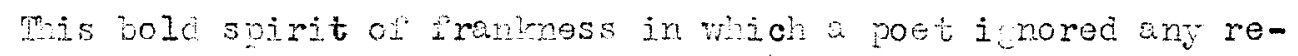
pressions to ot souting "ofi his cest," so to speain, exists in varyin degreas in the worl of most of the severteenth century metaphoicals, but re-conenty in the rotr of lome. It is seen in such a pesa e as $\because$ is irom Ralein's "The Lie:"

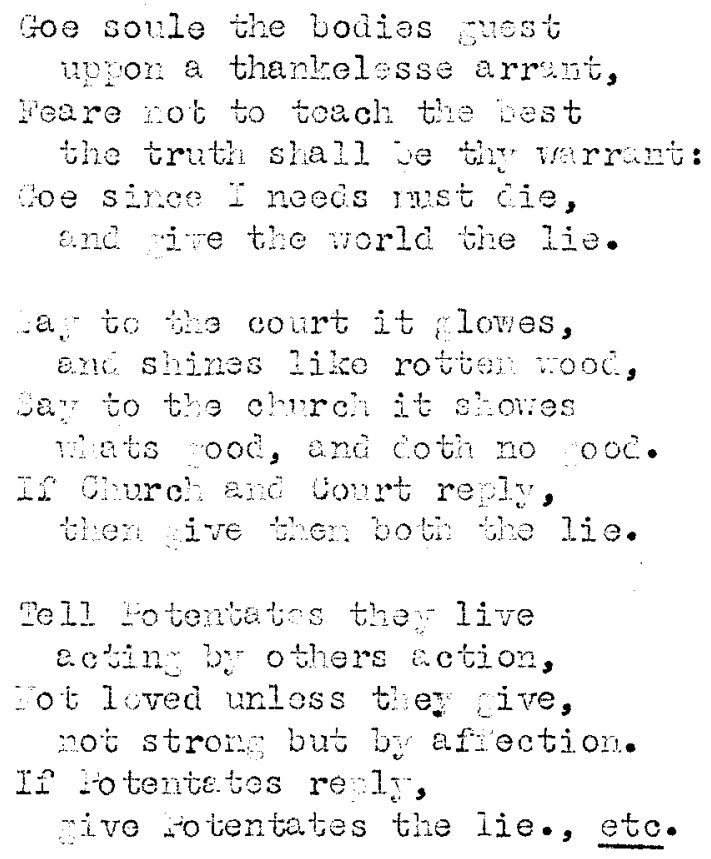

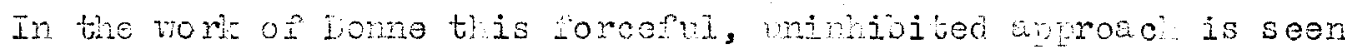
in his ratureljs,, is fremt sensulism and inis soul-bering psycholo ioal realishe phare is, for instance, the realiswand powor of the openinu Iines of "joalosie:"

Tond roner, mich would's have thy huband die, ind ret corplain'st ol is reat jealosie; in swolne ith oyson, hee ley in his lost bec, Is boce rith a sere-burte coterod, 
Irawing his brectl, as thick and slort, as can

The nimbzest orochetin usitian,

Eeace with loathome romiting to sme

Fis soula out of one rell, into a new,

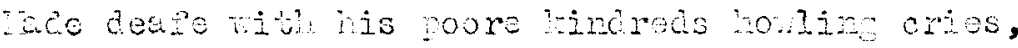

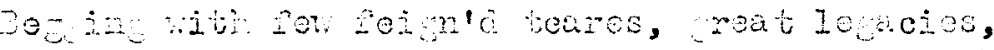

Thou would'st not weepe, out jo 1 , tard froliche bee,

se a slare, which to orroni should oe tree;

ret ween'st thou, when thou seost in hunerly

whilon is owe desth, leeris-jane jealousie.

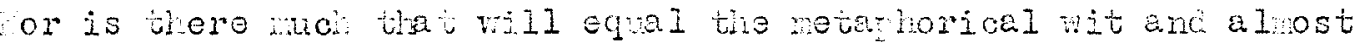

stertingly irank sensialjs: or suci nieces as "Lores fropes" and

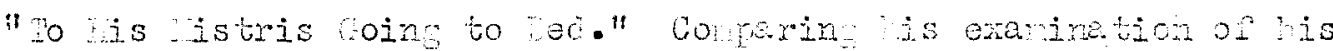

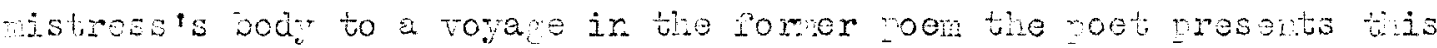

piece of unabashod writing:

There is a tree: mere closen pearls do swell.

the hewra, ser ciesvine tomo loth dwell.

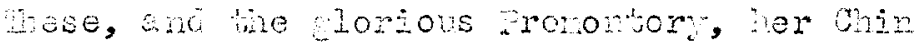

ure lest; anc tho streint olles ont jetweone

The sestos and ayos of her breasts

(Cot of two Lorers, but tro lovas the nesto)

succesds a bound less sea, but tot thine ore

some loland moles nte scattered boro desor

whe selin tomats her Indie, in that way

Shall at her fair fiartiot ave 1 ateg;

poue thence the current ae the lot nade,

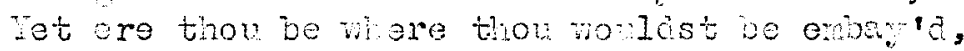

Whon slent tronon another forest set,

howe nan shipurect, and ro furtier get.

hnother phase of Dome's unhesitent, ejrect troatmont of complos

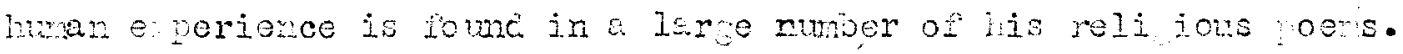

The steteront of deep feelin s and wental turmoil is remicularly

effective in somet $2 \mathrm{~m}$, the last of the "Yoly bonnets:"

Wh, to vex me, contrexres reet in one:

Inconstancy umaturally hath bogott

- cons bart habit; tlikt wer I would not

I change in vowos, axcin in cletotions.

As huorous is m contritione

LS Wrophe Hove, anc as soone forgott:

as ricilinly distemer'd, cole and hott,

As prayng as ate; as incinite, as rone.

I clurst not vion hover resterciar; anc to da

In praers, ant ilatterins speectes I court cod: 
Fo orrow I guake wi th true feare of is rod.

Lo ner devont fits come chi co amay

zilue a reytastique hue: sere that here

mose are bas dayes, wen I shake with foare.

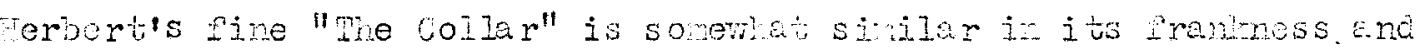

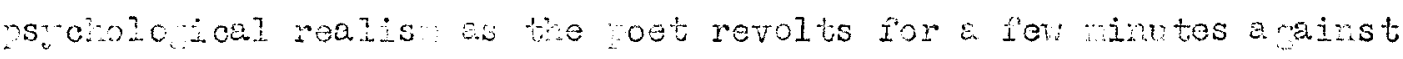
the strict dewanis of is service to code me roem becins:

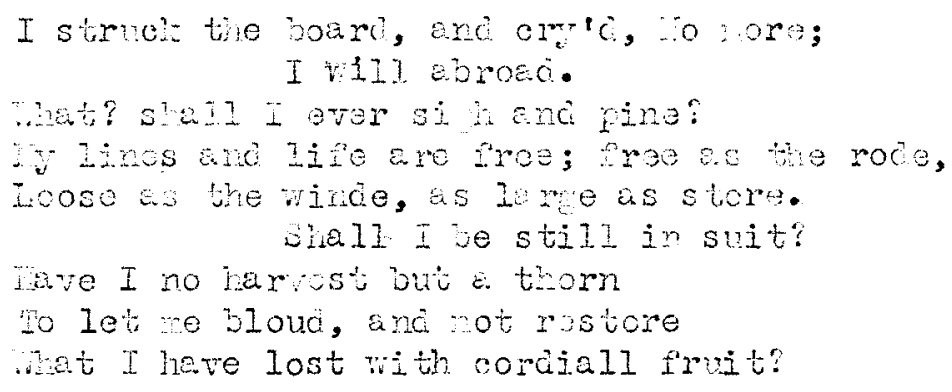

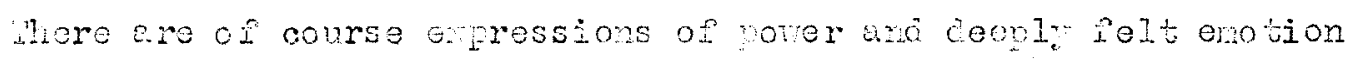
wibin ana outside tie ouern netaphojeal bracition, but thore is a

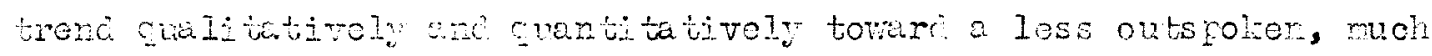
rore inhijitec arc precious stule of wrtug. The modern metaphysical poot is alnost elmers sophisticated and polisked end, excent for s pow oxception lile n. .lje's "One Znon" sonet sequence ard arren's

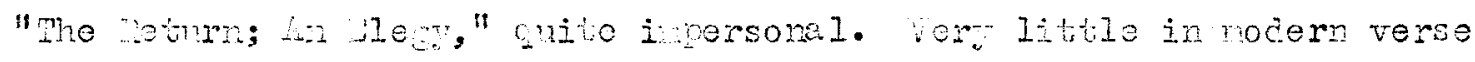

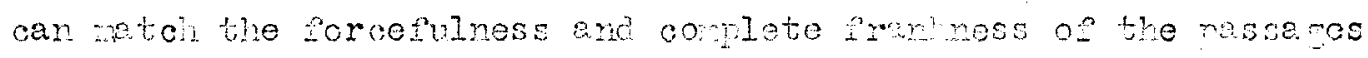
quoted e.jone.

True, Giere is a certain realis in the work of the ocerr nete-

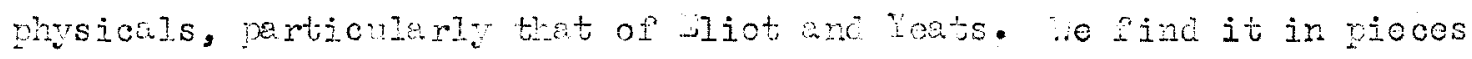

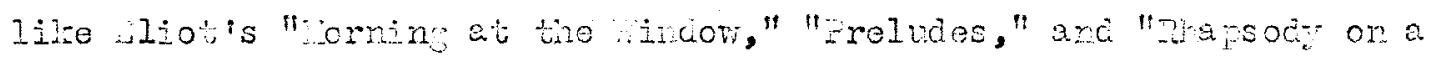
"Indy "ight" in Yeats's runerous howoly inages and in the gute soghisticatod sonstalis of oems like his "L Iast confession" I guote the first trio stinzes:

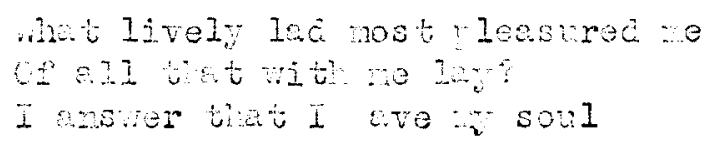




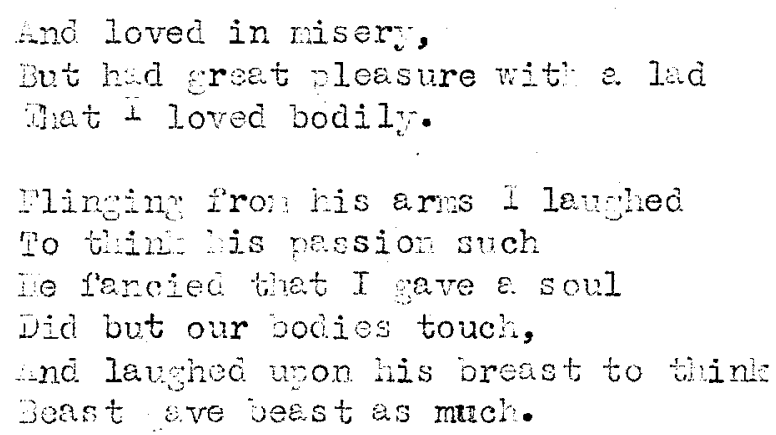

It is imedictely ericent whet wile a poon of this kind is cleverly amusing and hidily nolishec, it coos not woest tho onotionel inract or strength of personeliti of the Donne pieces quoted above.

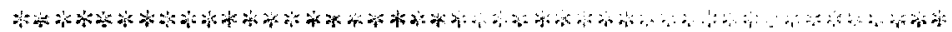

A delicete repinewent, rather than robut diectres, charecterizes nocem nobahrical verse. an straces of anerience are interwoten into an e.l-sutusin subjectivisx as foun jn such poon as knsom's "spectral

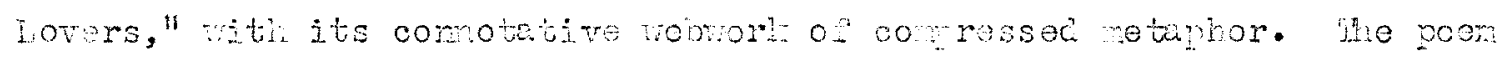

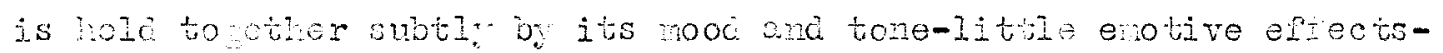
rather then by the unify ing force of a rorsonel enotion. wed to this

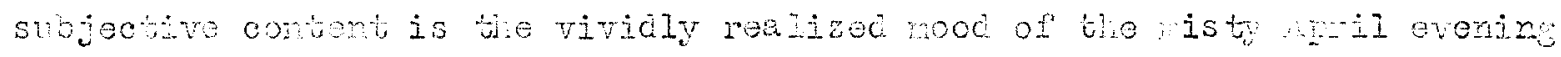
and the ironic slighty cordescondin tone of the poom. Guon a delicotoly

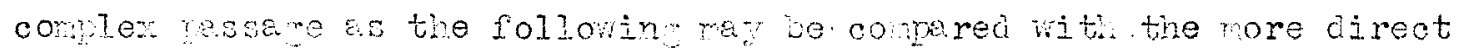
and intense arotional qualitios of the seventeonti centur verse quoted: storned by the little batteriss or an inpril ni ht Jessionte peing the essence of the field, Shold tho penetreble mells of the crubline prison yiela' wh oren up her treasure to to first clanorous knight? "Mis is the wad moon, arc must i surrencer all? if ho but ast it, I shall."

In to renoral toere, semal roticetion, this noow is besically

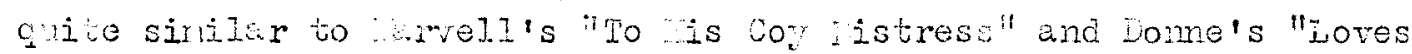
Progress," but it is in linh contrest in its liekty veilod, quite 


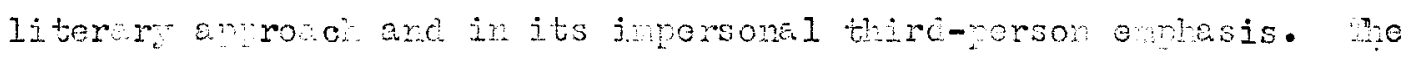
poet's hain-syatletic, half-satirjc attitude never is stated cirectr-

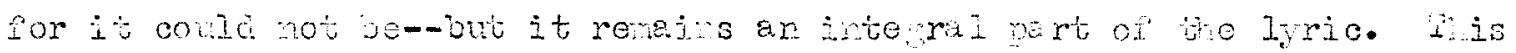

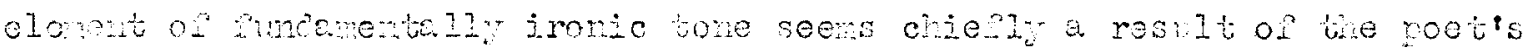

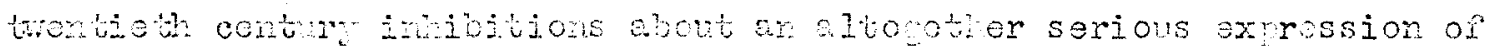
door enotion. Le sens to wis to participete in the onotion in some measure, vet to rucin abo it. Tis irowe apposch is seen of cours In the noving reforenos to the "Iitule betteries" juxtaposed to the "penetrable wils" and the "crublime prison," as vell as ir bhe stana's tree concluing lines.

In strong contrest to the seventeent century poets, the modern notahysicals aro also ver tiwic bout exressing reljeious fervor. In the rinete nth century a deer, comlex relinious feeling was relectec in the verse of iss ticinson and foplurs, but ir the twentieth

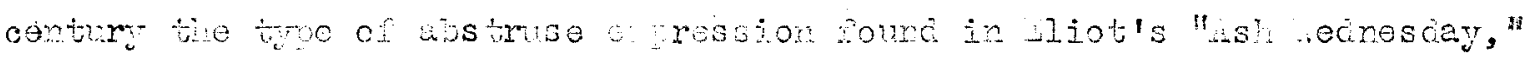
for exale, sees moro charecteristic of the noriod.

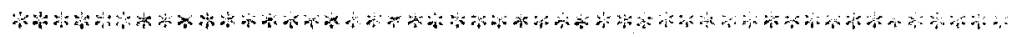

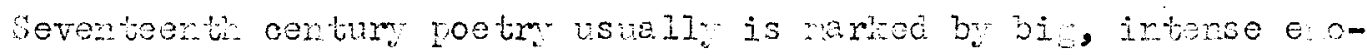
tions and tho vse of wit, wile modern vor is characterized by litto disseninatec peolins san tha vtilizetion of iron or setira. I have indicetec the funcanontel disienences in tro treatment of enotional anerience in the bro erjods, and will now discuss the role of wit anc irore in notarnsical verse.

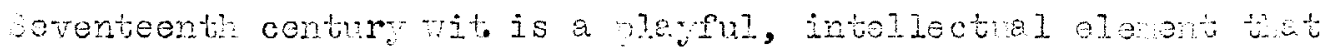
bencs to je reater neanin and lant to tile more serious, outional elenent in the roetry of the ere. It is of course closely associated with the notanheical love of leaming, the getrarchan-jizabethen 


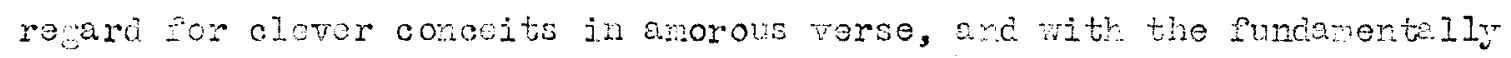
locical use of such dovices es metaphor, antitiesis, parador, the nun

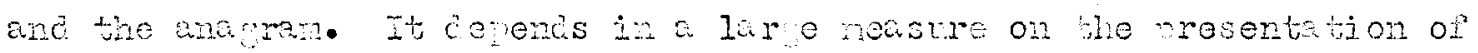

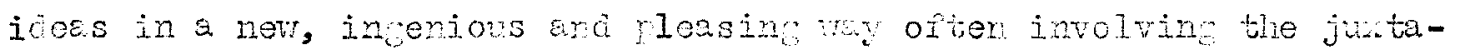
position of abstract sro concrete lancuage. inlis vas son in tonno's us of the scravled nare in "A aledictio: "Lo " $"$ me in tre ancon" and

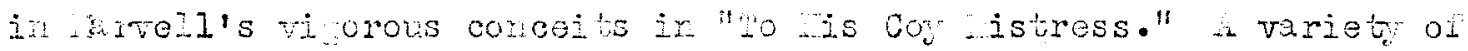

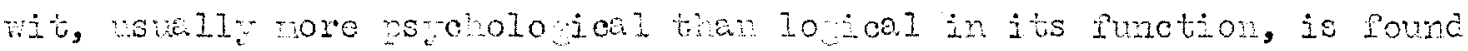
in twenteth outhry motaphrsical verse, but it is not-os in the sevenieenth contur--a distinct rar of the eve. severteenth centry wit in its rost characteristic and witiost Lom spertes ti rowhout Dome's "the Plee:" ari but this toa, are are in tis ow little tat mich thou cen'st me is; It suctid ne first, and row such thee, $\therefore$ in this flea our tro bloods mingled be.

Thov lnow'st that tis camot be said

$\therefore$ sin, nor share, ror ioss of matcorhead; Yet this enjoys before it woo, mo ner'd, sweIls with blook ade or two, wh tis, ales, is mre thaw wo would do.

o stay, three ifves in ono floe sar, here ve alrost, ye nore tian arrec are. Mis eloa is rou and $I$, and this our wrige bed snc arriace temple is;

Though parets erudge, and on, we're met wh cloistor in these livin als of jet.

ryour ve taite rou ap' to lill me, Le's not to tiat, self-mecer uciea be, and sacrilege: three sins in liling three.

- Cruel end sucier, last thou sinee Wmice the najl in blood of innoconoe?

corein colld to js las pult ve,

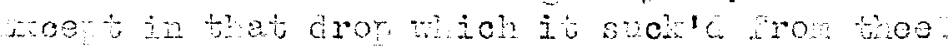

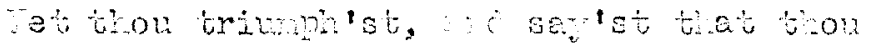

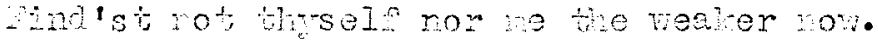

Ths tro. Ton lown $10 \%$ welse foers be: dust so moh honor, we thon hele'st to ne, ill waste, as this ilea's cecth toot life from theo.

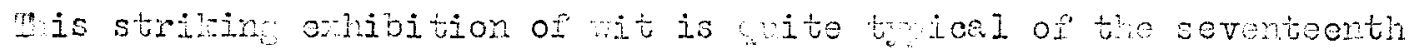




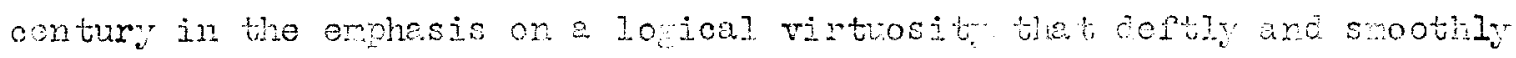
unites the serions--if not quite the sinjime-anc the ridjculous. row-

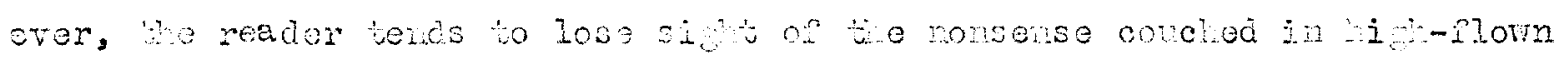
Jo ic as he acrimes the briliance of the pot's tecmique and is novec b. the muerlying esmestross of is plee. The woring out of the roer depercs on the bold, lo icel identinich ton of the Lew-ioton lorers and tho camirorous iles, ard the niece resches the heint of its inten-

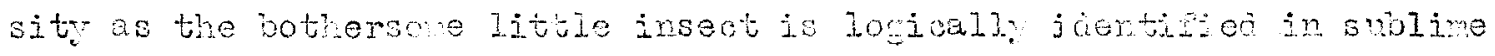

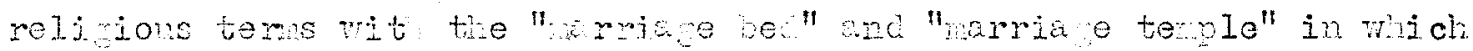
the nair ape "cloister"d."

woh of the poen's ijstinctive appen? lies in its lively, spontaneous good spirits--so different from the literar reciousness o nuch modem

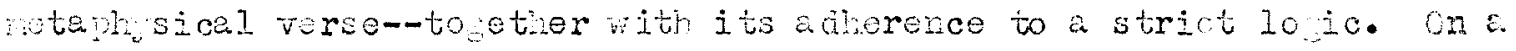
ljteral, brodly hunorous pane the lad's biting of the lovers is used to stroolize both a corporeal, semal union or a hipher hisical plane and an abstract watrironial union on still igher, spiritul plone. Ithough the poe is eveloped logically prow tie potaror, it is pillod with sprighty surrises as, at pirst, the fusion of the lovers' jlood in the flea becoses an erment for semel and naritel union and then, at the conclision, the lact act of "selp-murer" becones throun the poet's flexible lojic an even stronger arment for tis union. such is the nature of seventeenth contury wit in which the icea of the inherenty pootic meens virtully noting, and tho poet's ossentially intellectual incenuitr in fonding his naterial is alnost evor.t. ing.

In the reli ious poetr. of Dome and other seventeenth century

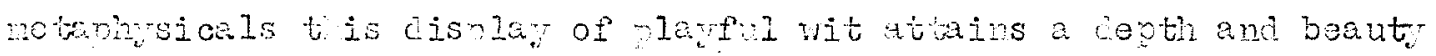
winch ofter touclos upon the subline. Frowely the nost besutiful of Donno's metaphysed word-la" is found in the "La Corona" sequence 
or seven somets. Whore are indeed few lines rore emposive than those of "irmuctation," the second sonret of the sequence:

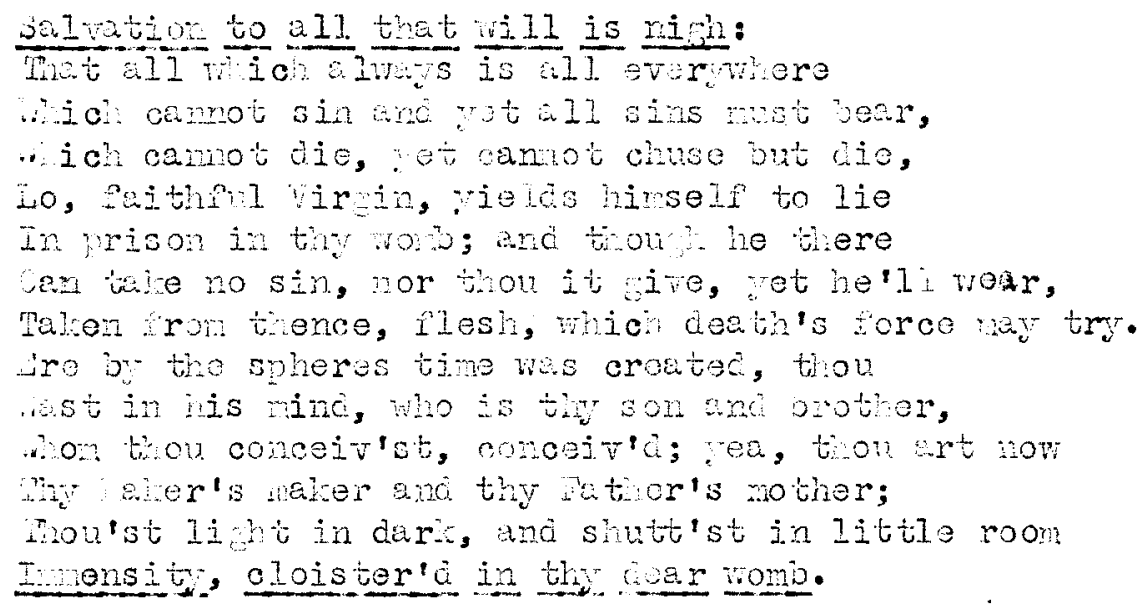

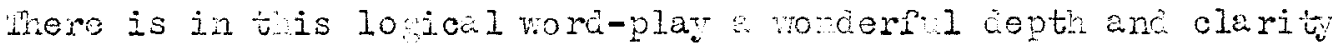
of though chored wt a buming onotional intenst . Mis guestion natureily arises: Low can such an ovviously uriticial bevice as rovi12. assist the roet in converin to his reador a rore manim ful end vital sonse of exerience in all its berron beatu? onl a brief enam-

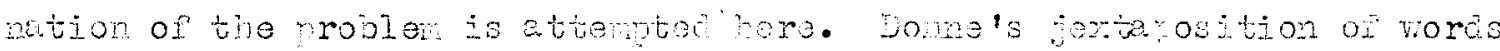

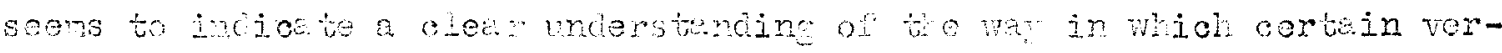

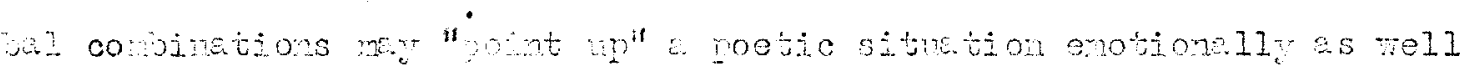

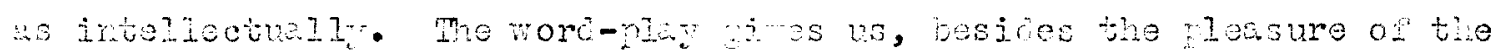

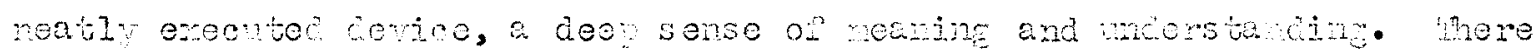

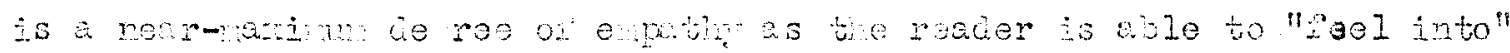
a sitution. Dome he apparenty utilizod ohese lo ical doricos to

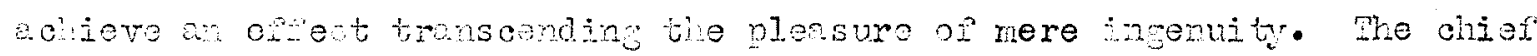

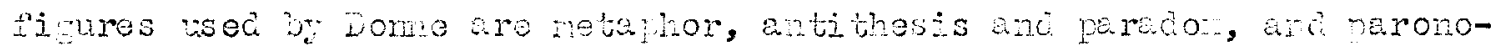

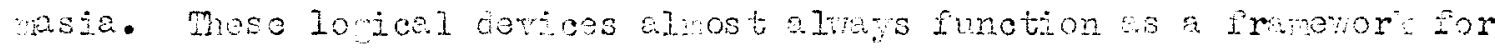

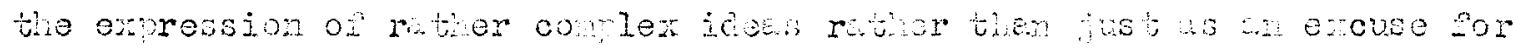

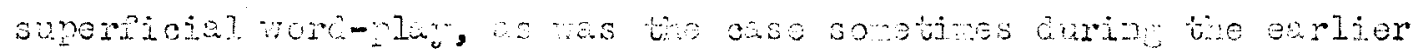
inglis deneissarce veriod. 
Tho functins of these basicaly logical ficures are clear. Pirst,

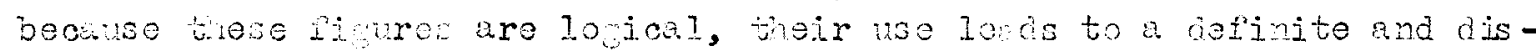
tinct statenent of an idea or an exerionce, roter than a roter vane,

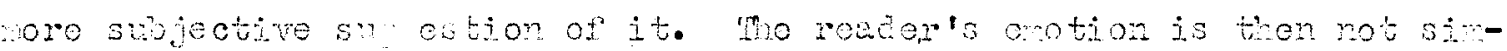

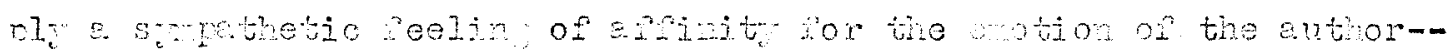

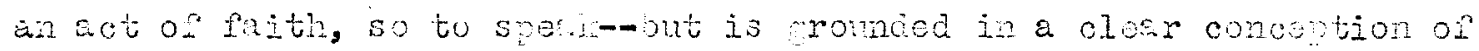

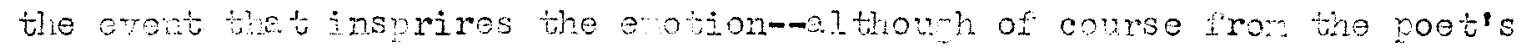
riempoint, weondly, the striding similaritios or sarp contras se stated

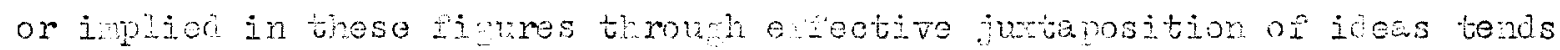

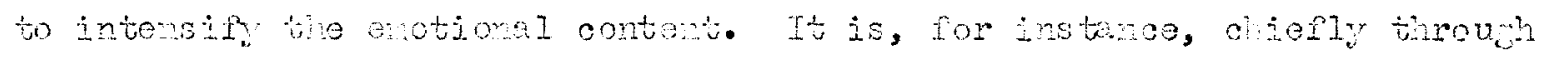

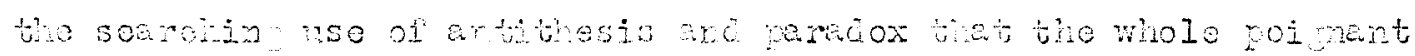
tregedy told jw be "La sorona" soness is made imediste and vital.

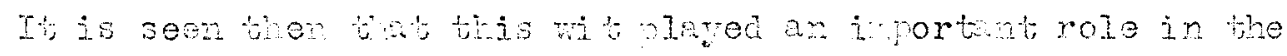

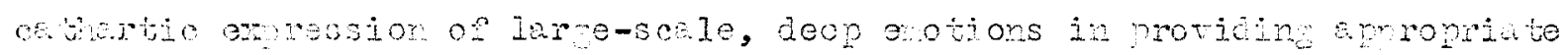

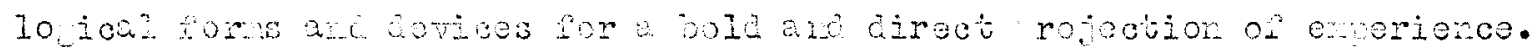

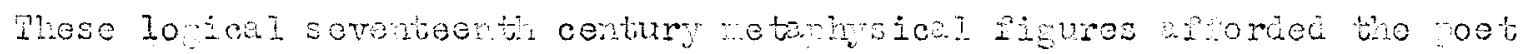
ar a thotic control throwh wich he co ld oranise and chamel his ewo-

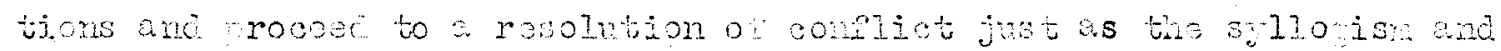

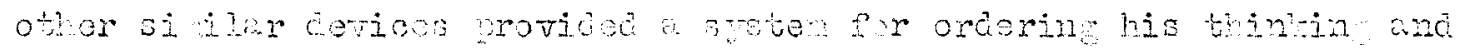

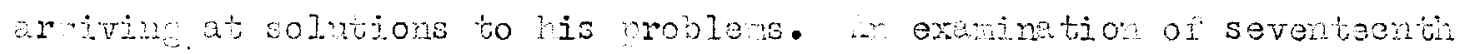
century netahricsl vorse indicates bint the pot was utoth an ena

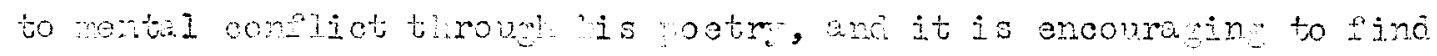

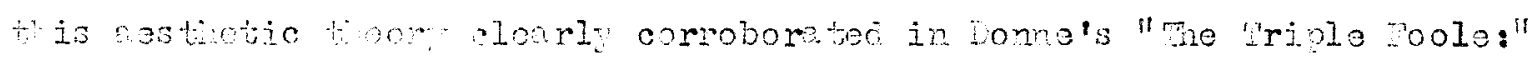

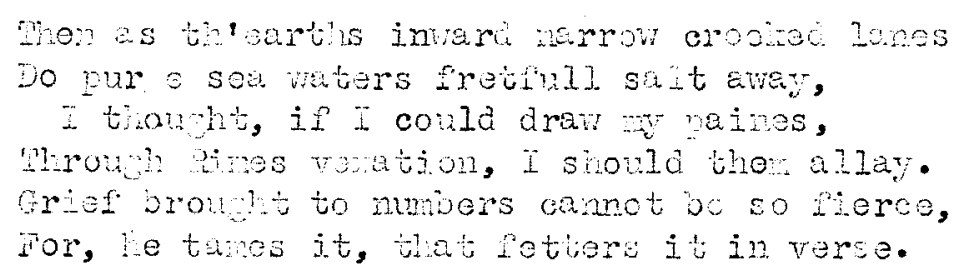




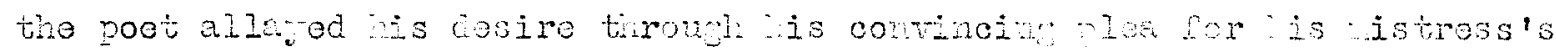

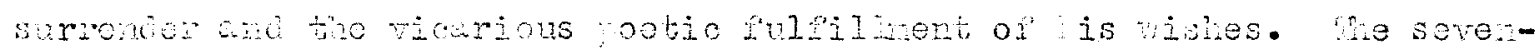

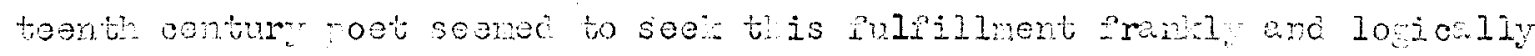

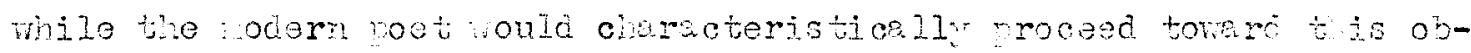

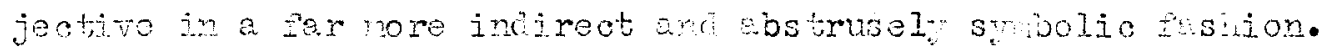

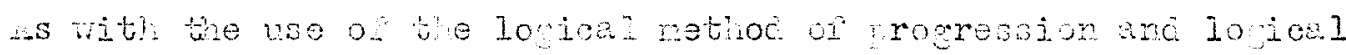
chapor, the soventoonti century 10 , ical wit is carrsed orer in a

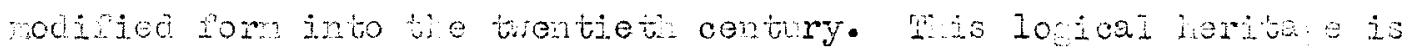

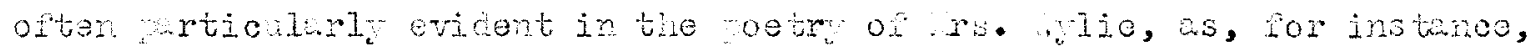

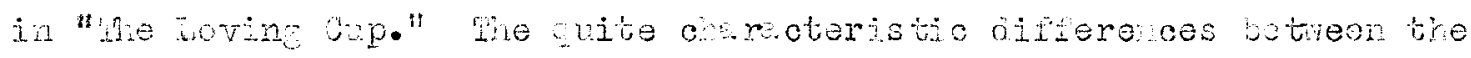
use o. it in the tro centuries car pe further illustrated in a com-

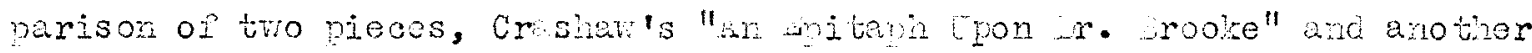
mile poan, "ro A coun in the street at iduint." ne two are o-

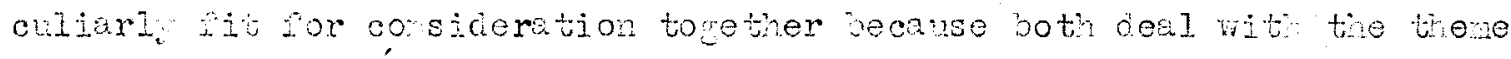

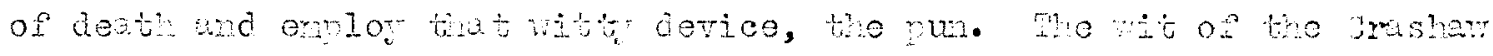
niece is ourions:

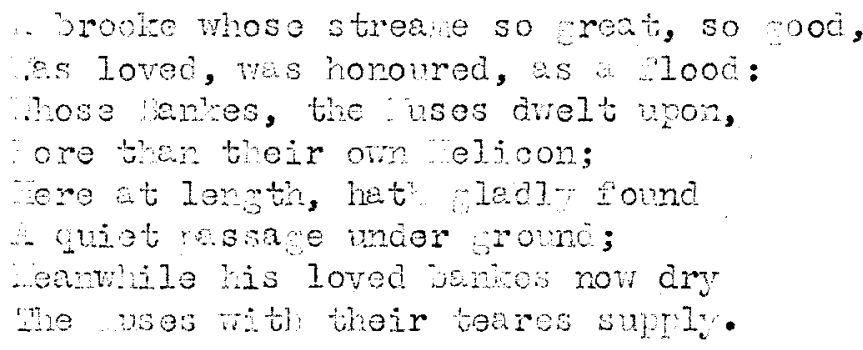

There seers to be nothin: ili want or disresvectul in the ingenious extension of the conjination nun and metaphor through the einh-line coem. On the contrary, the silil and aroropiatenoss with wich the poet handes the figure, portiontarly in the reperence to the "quiet passege under aroma,"

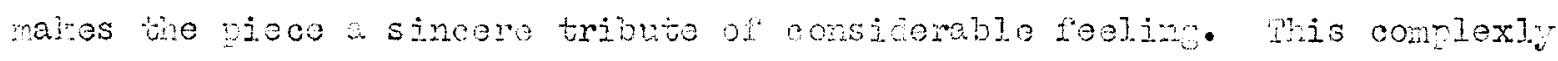
oriered wit, jovers, ives ever to tijs death roen an ojoment of certaint and accentance.

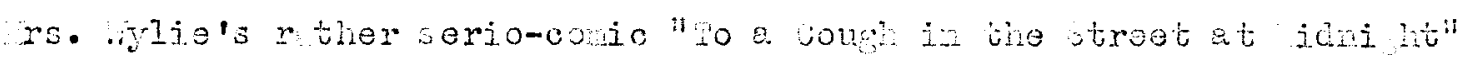




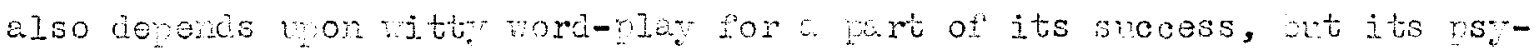

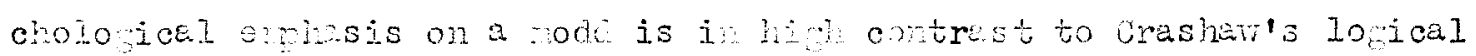
elaborition of an artipicial concett:

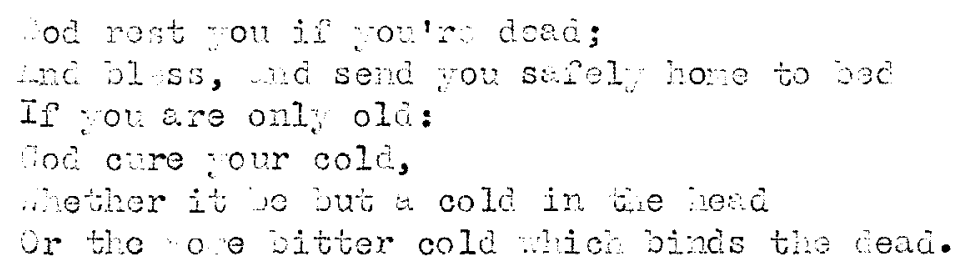

The poer succests serententi century dechighe jn its use oi

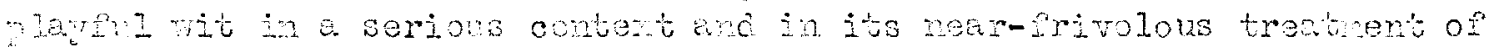
a serious thone, but the most imortant wlitu of the yoce is atil

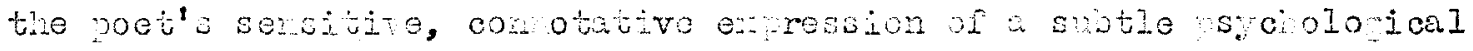
everiace. This poen's general vagueness and its sycholo ical pro-

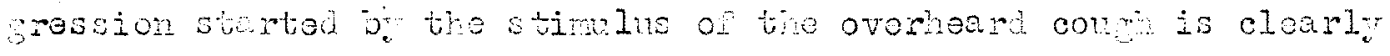

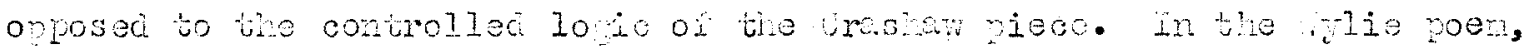
of couse, the senso on exprience is less well ordered, but far nore imediats.

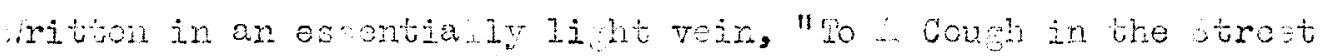

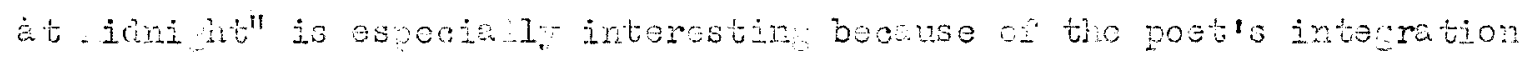
of the conotatims, serjons ar coic, wich she drans from the everyay

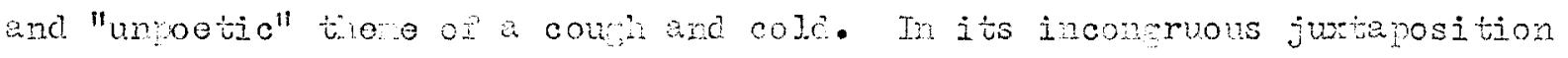

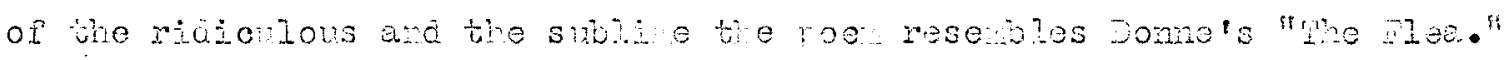

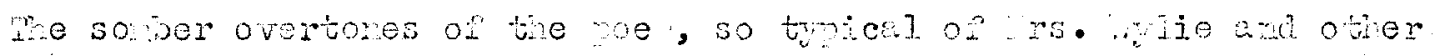

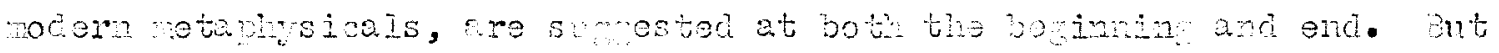

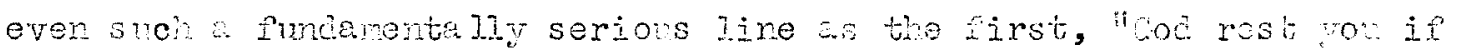
you're ceed," assmes a conic eflect due to the sudcen and feiliar fash-

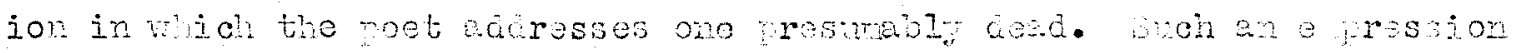
as "God cure ron onle" is also ossontinily hu orous in its wersing of the plipent and serious. 
We nost strining device in the poen, horever, is the pun on "cold,"

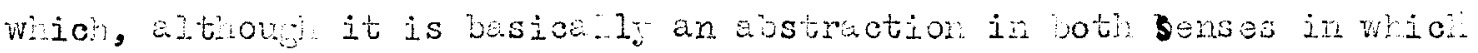
it is used in the poen, is lacen mith stron sansate connotavions in all

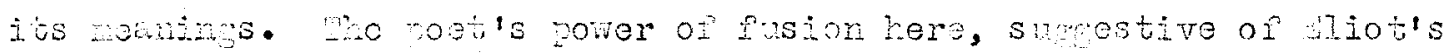

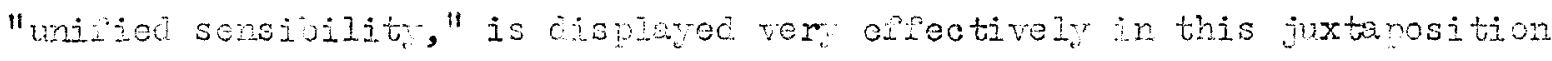

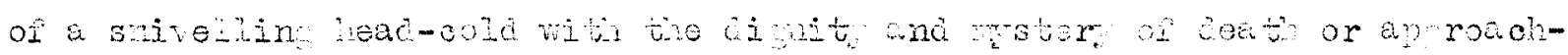

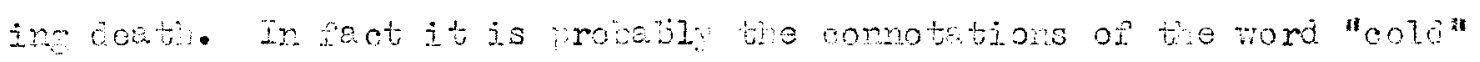
tonetien wht the veruel surested picture of deseried streets at wi-

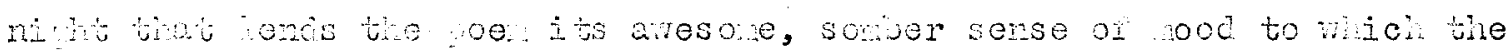

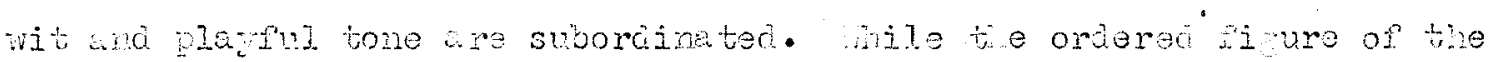
crashaw poon and its jaea of death as just e continued aujet wassa under sround" sugests pris rily a positiva aroach of eccentarce, the

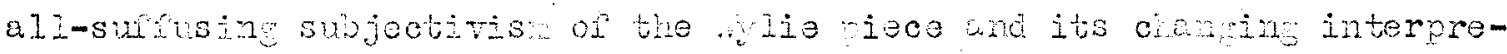
tecions of "cold"-mavering betmeon the subine and ridiculous-create

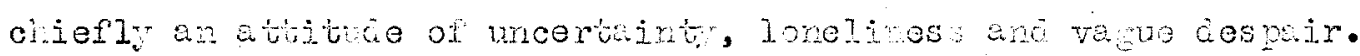

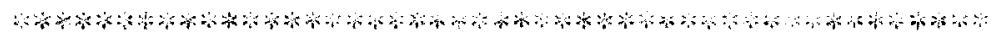

A much nore characteristic quality contributing to the complexity

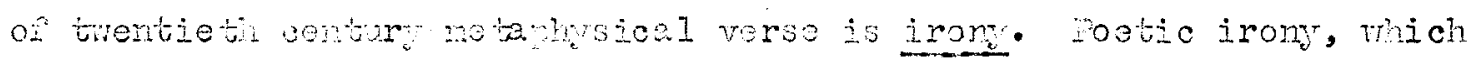

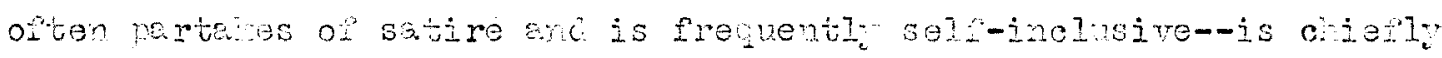
a brating into the tratiment fi experiance sn oposin attitude, a aissonant note, se thet tie oetic jnterpretution is rot vulnercole, to

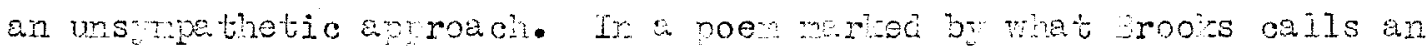
"ironic contemplation" a poet's mlling over a lost love wi ht be jalanced, so to speaz, sy anelent on self-incl sive abire--3onemet as

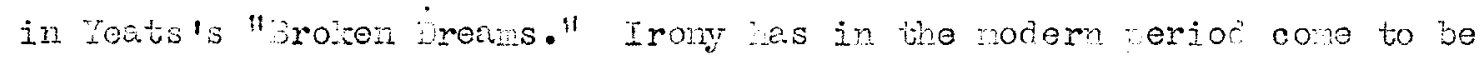

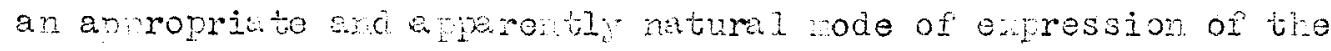
"disillusioned incerlectual" tpe of poet (like diot on occasion) who, 


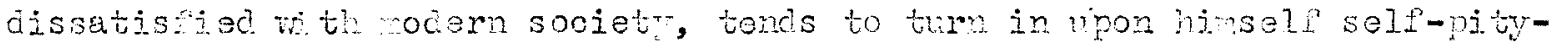
incly, and of the semingly inhibitec nodern poet (iire nensom and the

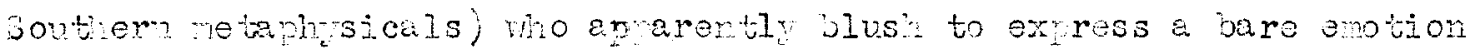
ungulisied pre so histicetec iront.

.hilo wit, althoug often contributing to a projection of deap

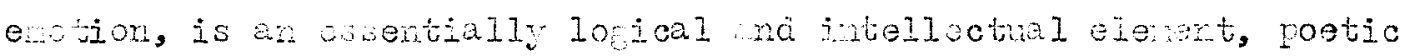
irow, perticularl in wodem nota hical verse, is on the nole a

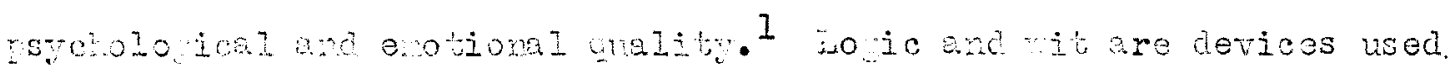
to bria a cortain esthetsc orier to ti e projection of enerience,

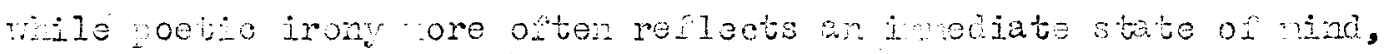

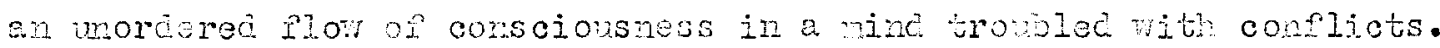

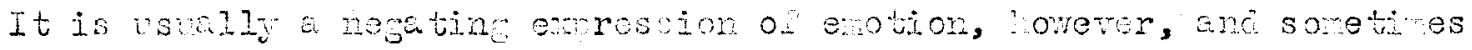

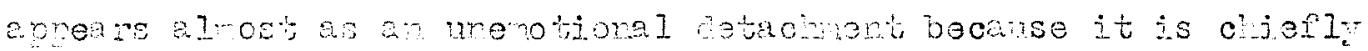

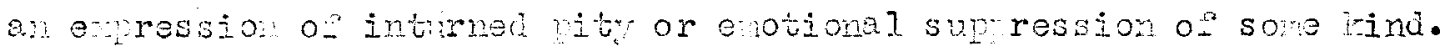
Poetic bone, reflecting the poets atuibue toward hiselin and is poetic anterial, is closely rolato to the use oz irone.

1. sovera tocen critios have discusse poetio iron, aithough sonetines amloring the ter so tht it juchos the concept of wit as we 2 .

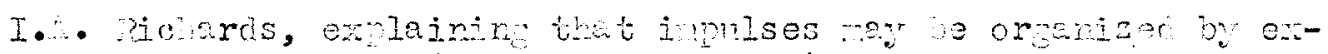

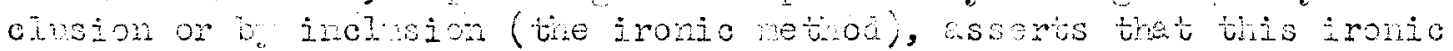
"equilibrimi of op osed impujes" ar be the "rome-len of the

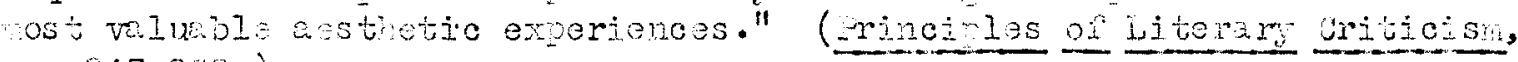
pp. $247-2.5 \cdot)$

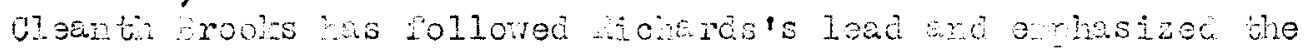

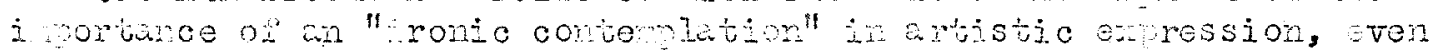

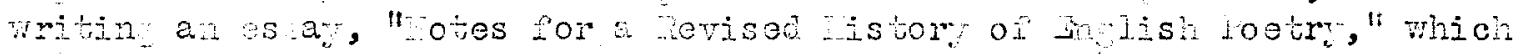
point out the ajor apperances in molis literstire ut ironic con-

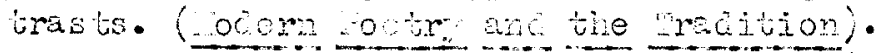

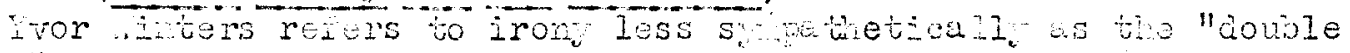

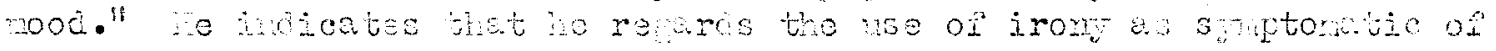

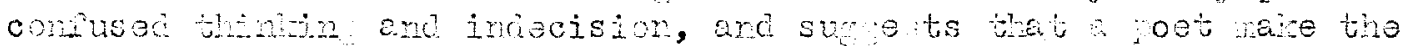

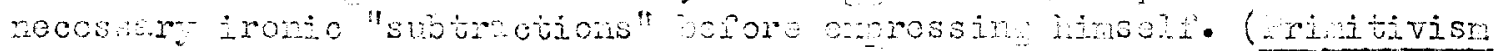
ance jecaderce, "The $x$ orimotul school in locem -oetr" " 
Wis irony has jecone a charteteristic ey ression of our a de, but is also found in sonenat cifierent forms in some serenteent contry

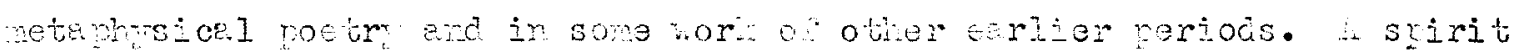

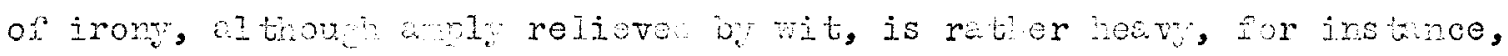

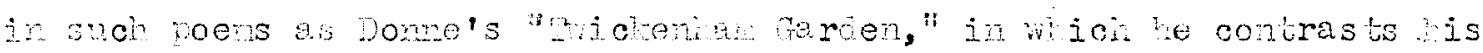

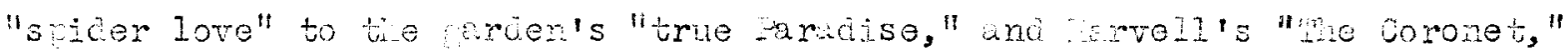
in rich the poot ciscovers the "serent old" luring in a claplet of flowers intended for is avior's tead in wedess of old wrone. In the ajoteentir century, with a few ecaptions line to pootry of blaie,

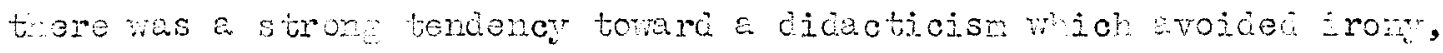

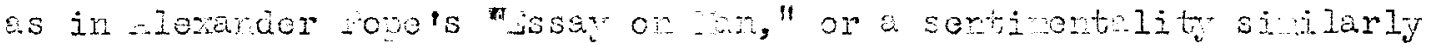

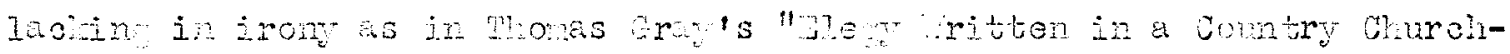

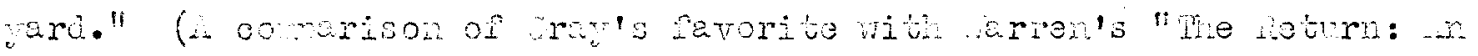

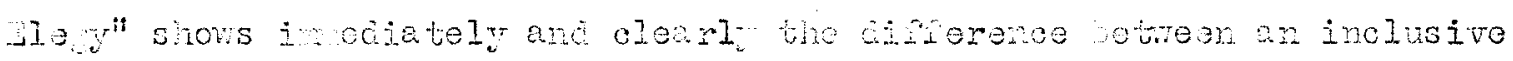
and exclusive be 02 potr.

-n enotional amroach un walinied iron continued to reobinate

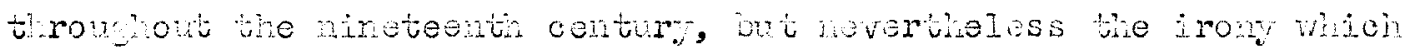

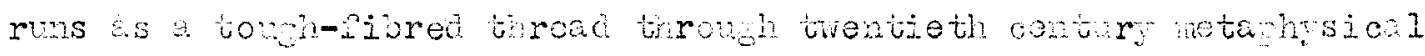
roetry and oblier nodern vorse has its roots in sone of the no r of the

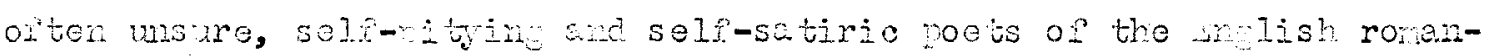
tic anc renci stroolist schools. Ijio tie as oholotal, comotetivo

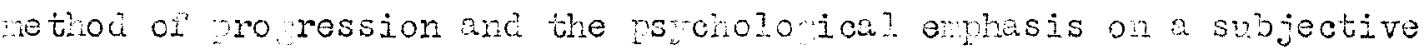
mood, this nocern irony is part of a herita fron thaneteenti contury

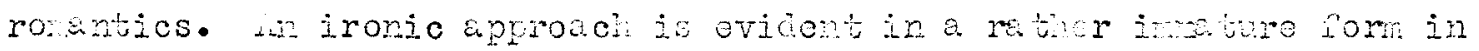
mich of the mori of word bron con in a wore enedive fusion in some

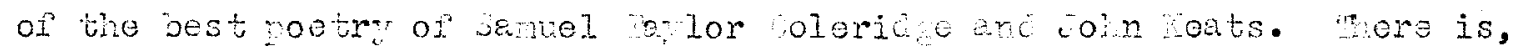

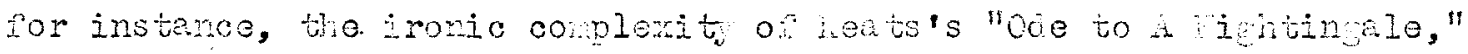
the two closing stanas of wich I quote: 


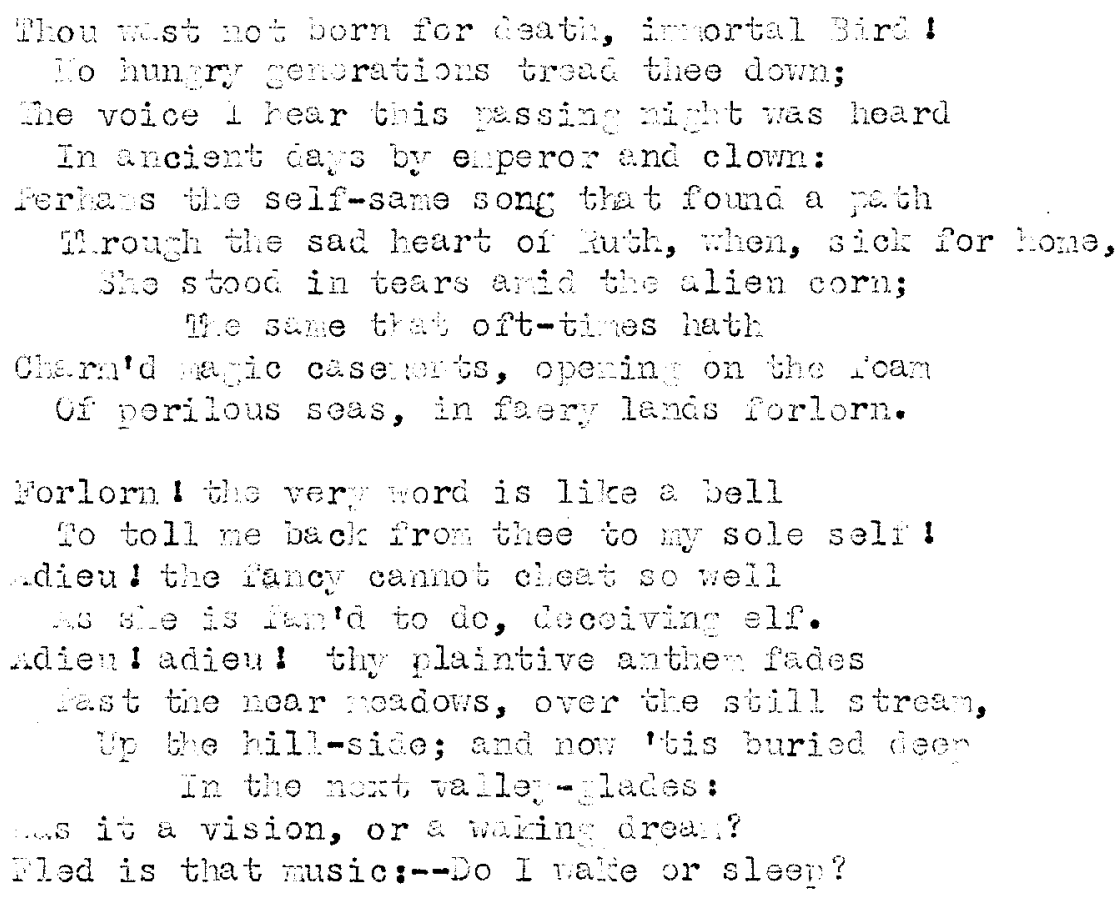

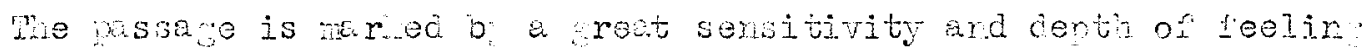

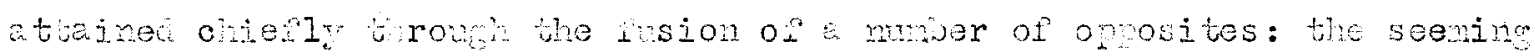

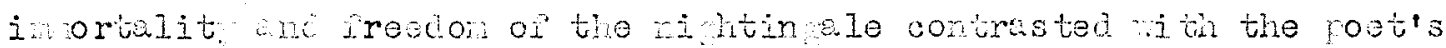

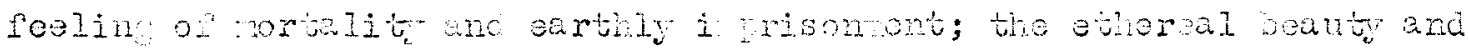

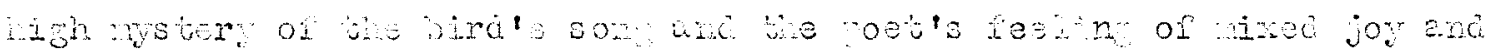

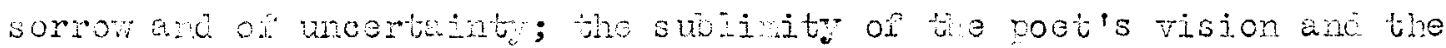

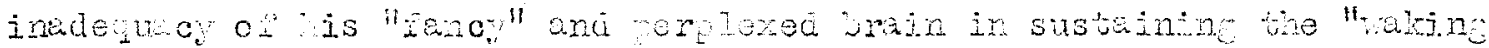
dream," we the seriousness of the the we the irome and it in the

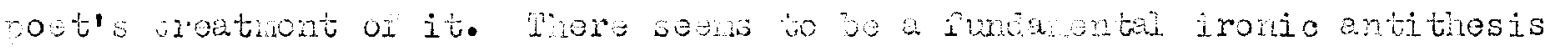

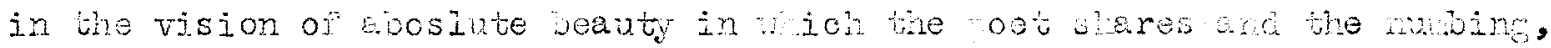
uncertain actulit, in wich he dwells.

is sinjar union of oprosine innlses is seen in the vxtanosition of the rolome beat of the son; and the doe sorrom of kuth, and in

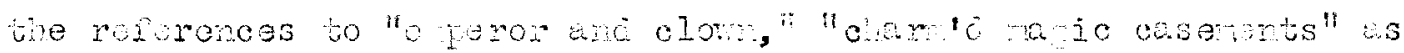

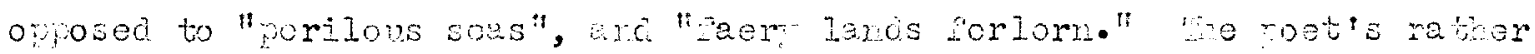

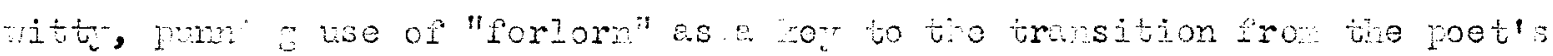

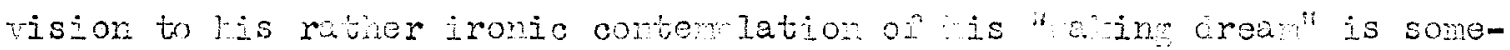

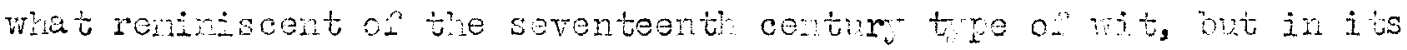




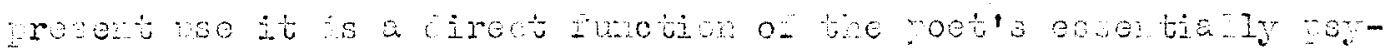
elolo jeel nethor or rogression.2

Ieter in tha century corbierro, Leforve and other rench shm-

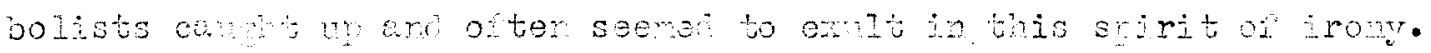

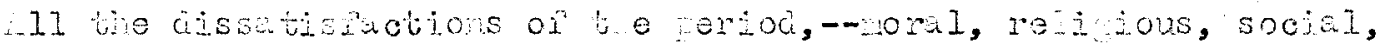
roliticel, artisto are intellectel-nown their we into sy bolis,"

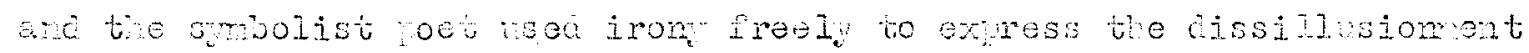

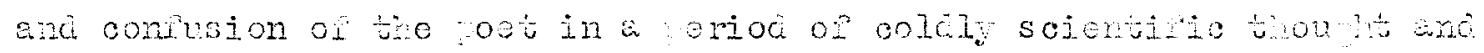

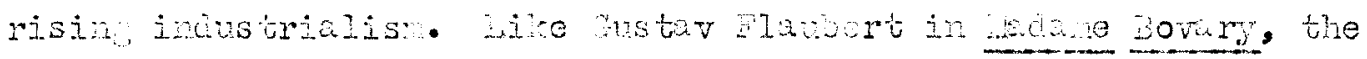
smbolist poet ciescriped whutel; the instincts of wen snd wowen anc

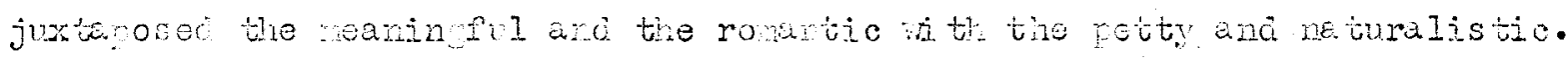

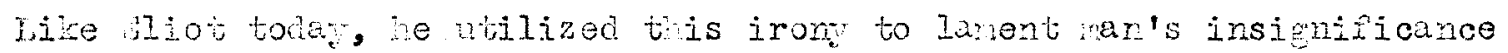
and to re ister is fealin of isolation and colpuson in a society witz wide he conld not icontily linselp. The rench subolists' coneom

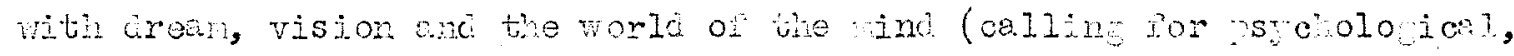
comotetive structurea ) ano tiejr use of jrong are closely interrelated aspots of the smolist psyolo, with its strateg of revolt anc

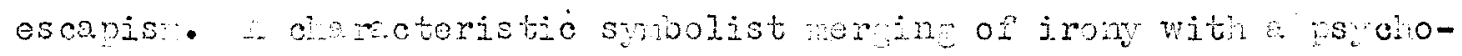
looicel propulsion is seen in iaforge's "Wod jcepticue:"

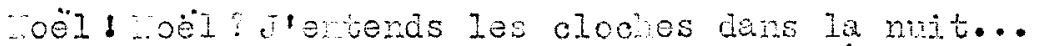
Lt jai, sur los fenjllots sans foi pose ma plune: o souvenirs, chanter! tout on orgeil s'ennit, it je ne sens repris de a racte anertime.

Ah 1 ces voix dans la nut chantant Toël l röll -.aportent de la nof qui la-jas, sillumine, In si tencre, un si doux reprocle meternel we mon couer trop gonflé creve cans poitrine...

1. Lects epiains is leasure in en ironic merpine of contrasting ipulses in "A Son or Op osites," ceclaring his love for "sad feces infeir weather," "infant plaving with a shils," "serperts in rec roses lissing," oto.

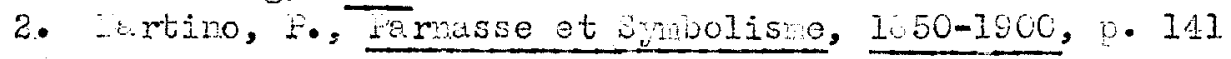


it j'éconte longtemps les clocies dans Is nuit...

Te suis la parie de la famille humaine,

$A$ qui le vent apporte en son sale récuit

La poigninte remeur c'une fôte lointeine.

The ironic contrasts in this nece ere noce violent--ierkins nore naive--than in heats's "Gae to a inhtir.le." jevertheless the two poes resent a sinilar patiem in their interprotato of onerience.

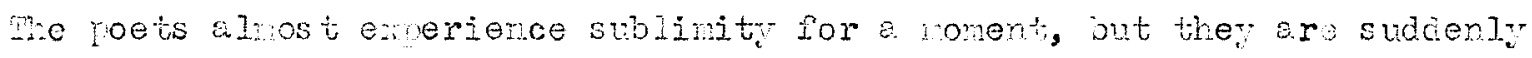

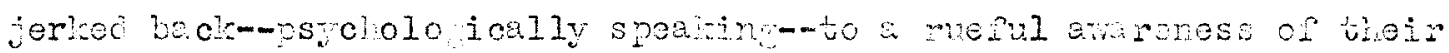

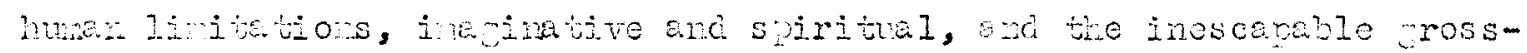
ress and potimeso on actality. It is en ameriential pomule thit las come to be comon to much rodern potry with an ironic cast, arpearine

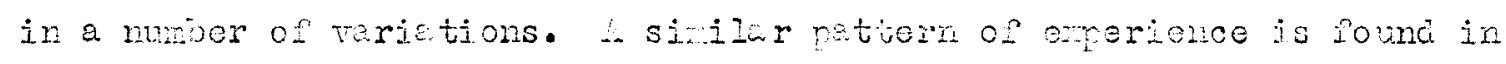
Laforeves "Crépuscule de Dimanche a'té," in the closing passanes of

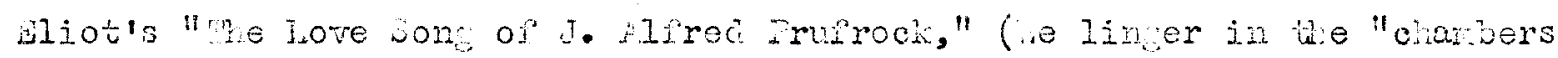
of the sea"..."Till huan volces wivo us, anc wo arom") and in ranson's

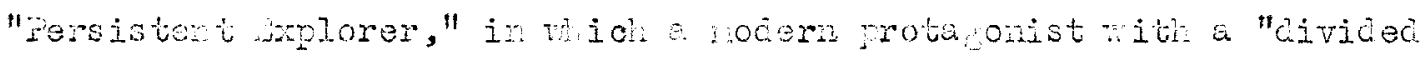

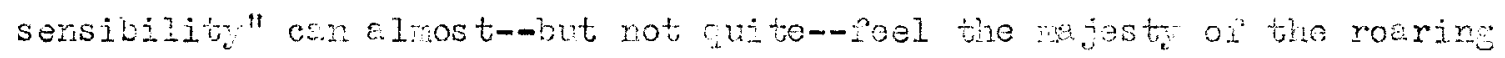
of a wheralls as rineer pepertorr feols th is over in tho as am's

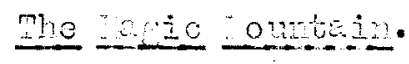

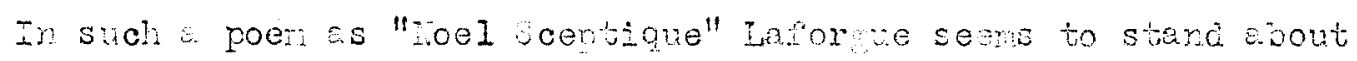
half-way between the rontic irom of yron-wo pitied hivself as a

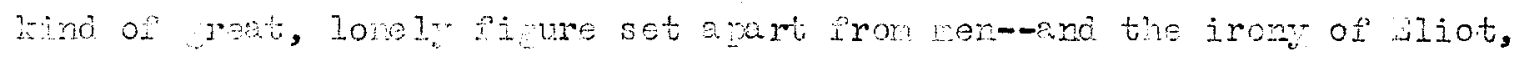
hansor and ate, wo pity trenselves and twentioth contury man because of the near, deadonin routine of noom line. (wis reaninless rome of

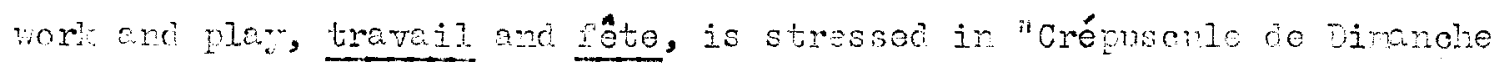

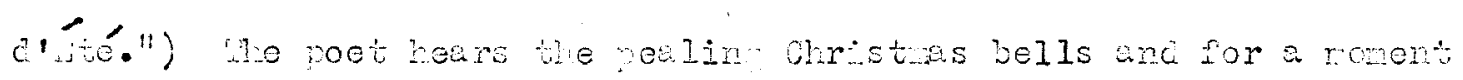
surrencere linself to olc remories end the joys of loel; but le leels that he is one aprit end without rats, and the pleosure rows hollor. 
Le pities hirself as an outcast frow ankind--"la paria de le lawille

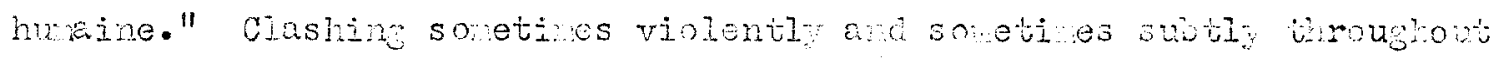
the yoon cre the poet's oposin feelings of subinity and mion with won and of stopisios and epartnoss. The ironio contrist is sumested

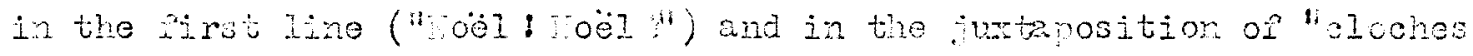

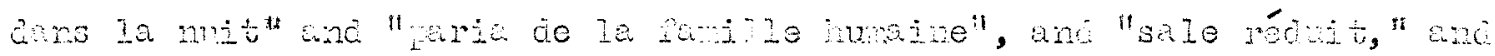
"lête lotintine.t.

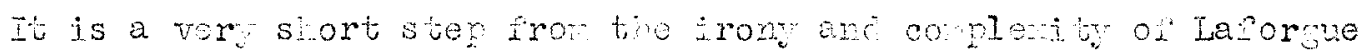

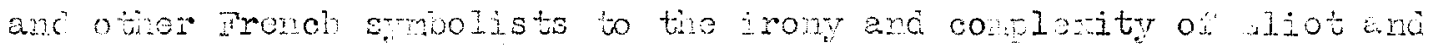

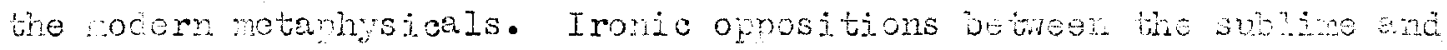

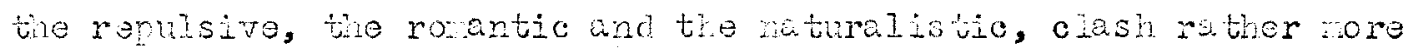
shary in mon of diot's earl vorse than in Laforgu's works consicer, for instance, the inonic contrato in the olosine rassages of

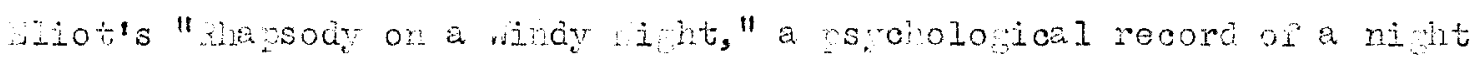
walle in a nocem city wetween wini git and four o'chok in the roming:

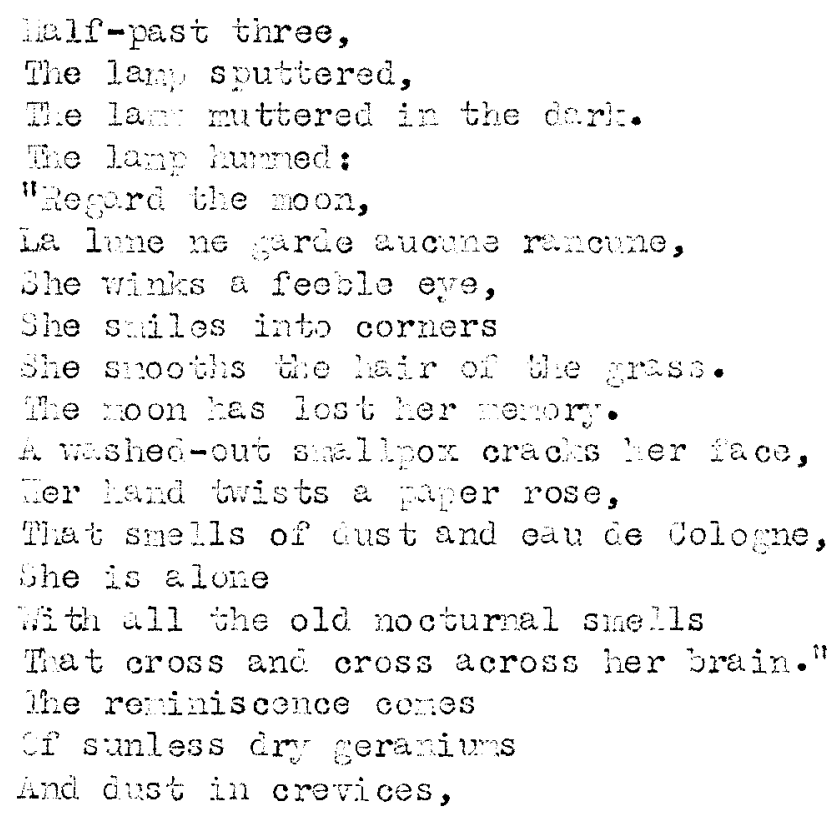

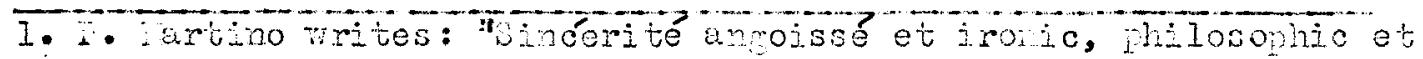

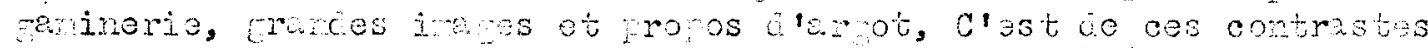

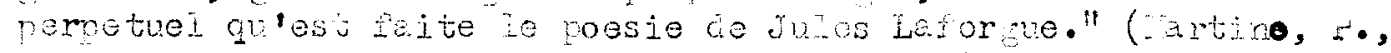
OD. cit., p. 149 
wrolls of chestmits in be strects

na fente scols in sluttered rooms,

ni ci sotes in corricors

fod cockteil snells in bars.

me ransaid,

"lour o'clocle,

i. are is the mabr on the coon.

cenom!

wou lave the trey

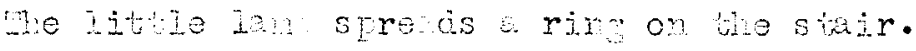

oinge

The bed js opon; the tooth-bush kens on the vell,

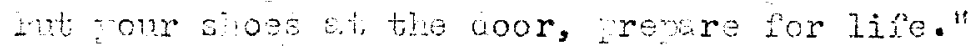

me last tist of to mife.

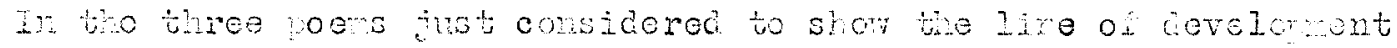

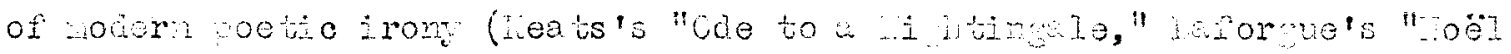

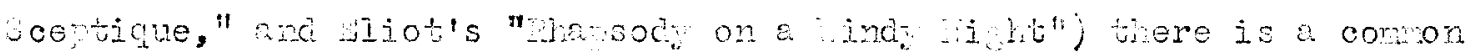
vaturn of ironic opposition between a siritul or acothetic onerionce

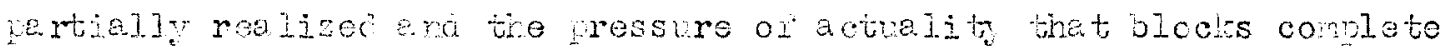
realization. It is imortunt to note, however, that this cume ol development reveals jropenively less enthesis or the positive ox-

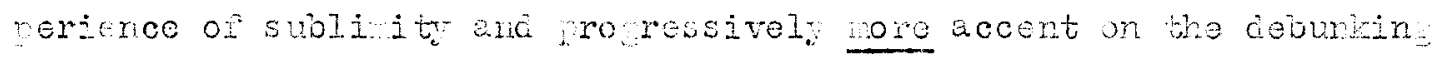

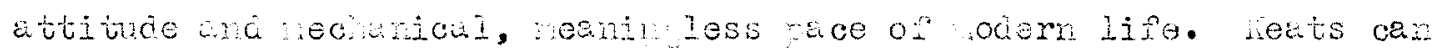
lose limelf for a wile in tre becuto arc worda of the righinale

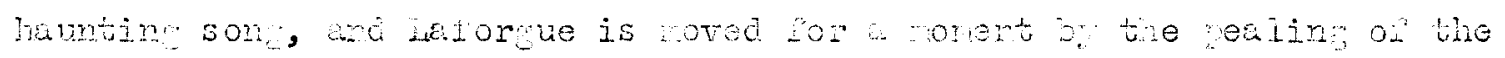

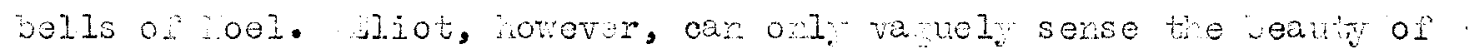

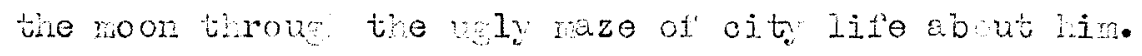

ine irom of the sitution is rojectec sherply as the moon,

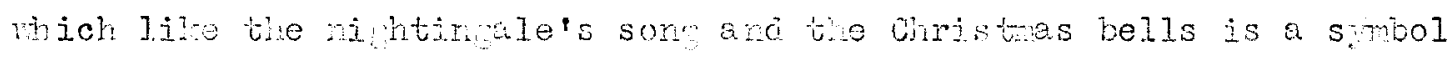

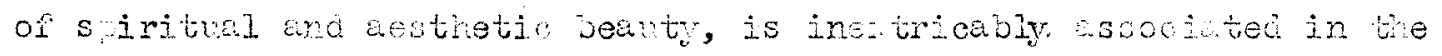

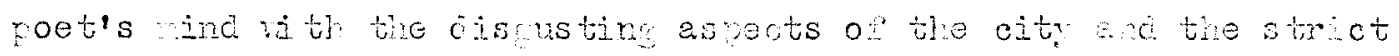

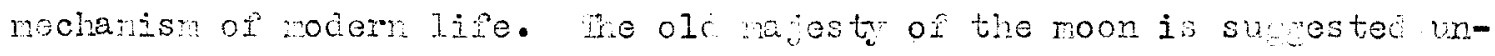
certainl for a nonet in the rench phrse, "la lune re arie anoune 
rancume, thut in the next serend. lines, in the reforerces to the winlume "foule eve", the "rashedout smilpoz", the "paper rose" and the "srents of cust an ean de jolone", she sumosts a hariened prostitute rather then the lovelr miden of romantic lore. The lifeleswess of nodere life

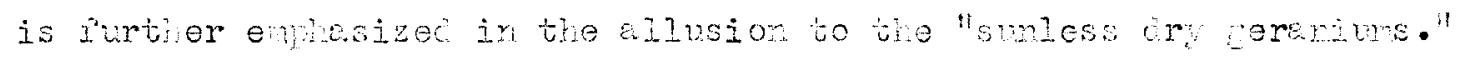
ore concerved wit the street li,ht, than ith the loon, the noet acts onl accoin to conditionod responses, arere of the rasero of erer.

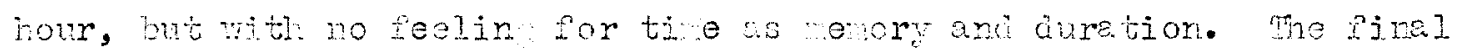
cuttine trist of irony is at the conclusion where with a jitter, self-

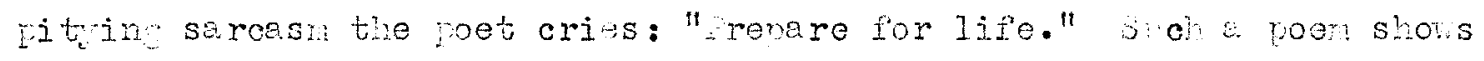

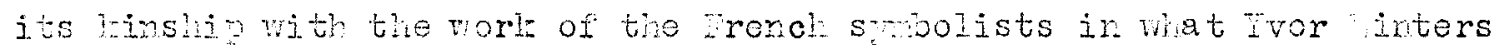
calls its "cousle rood" a contimal vavering betweon a supestion of

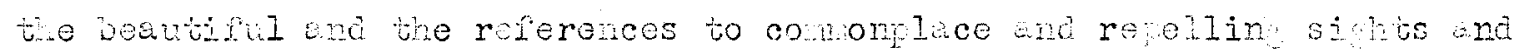
s?:eis.

iliot's "sweoner son the intinales," wich rithe be comerea

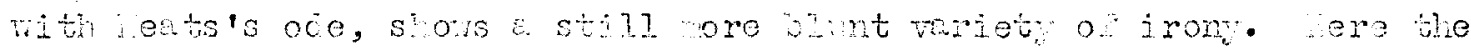

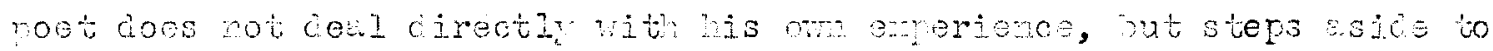
revel that bie ocem boureois citizen has ro peelin ats 31 for reaninvul exerience. here is ro loner the conliot in the noets ind between a ostive tecing os subilat are a negatre pressure or life destrovin. th is feeline rne proto onist of the oes, ineneck sweeney, is solely concemed wi th hediocre way of life ancis altogether inrervious to the peavio gout inde To be somewret nore precise, weeney sems to be recreatin. in rother suspet quaters with sone wonon of rether questionable ciarcoter, wile,

Me riotinales ro stming near

Le convent of he bacred bait.

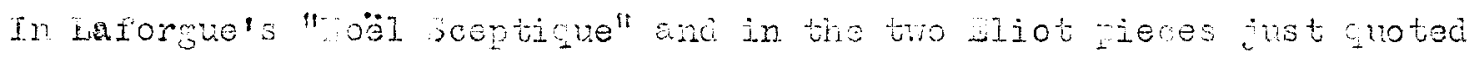
the poens end or a seli-conscione rote of irory. he iron eppears 
to be the war point of the poen. The roet's attitudes aro lay reatures of these examies and are expressed in the jronic "tone" of these poes-neriag their nost noticeable characteristic.

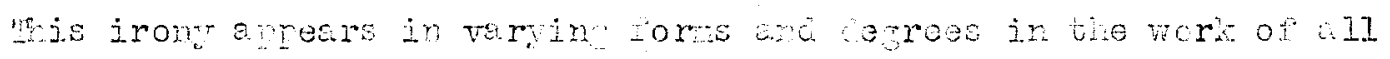
tive rocem metaphical poets. It conditions the poets axposion of enotion, ene is de des utilized by pots wo are aws of tre con-

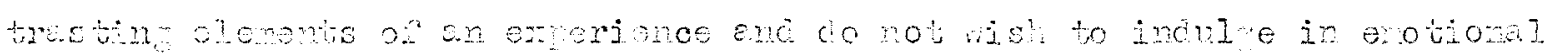

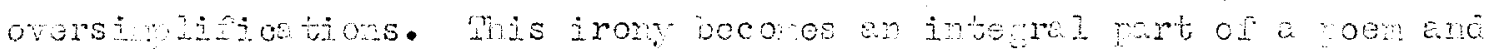

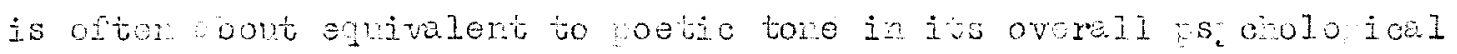

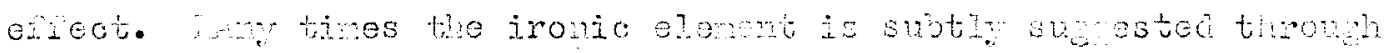
notawor, is noted in the las chapter in rejprenes to Toats's "jailin

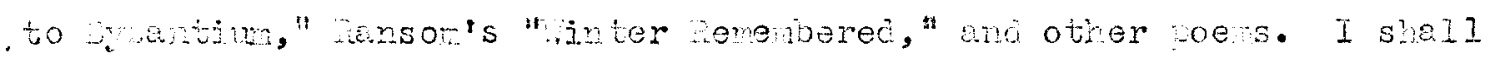
try to poirt on its zor aco sunction in severel otler rodem poens end to diferatisto vetween its use in the seronteonth and trentioth centurios. It js nsed, tor instence, to attain a ver eftective form of twentieth century "high seriousues" ir two poens treating a death thene

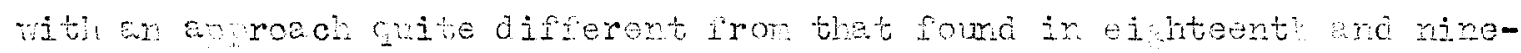

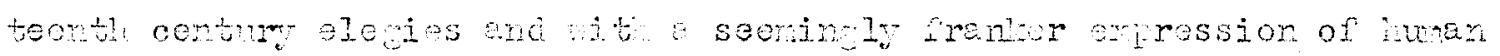

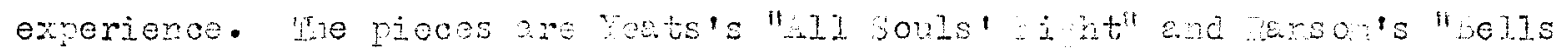

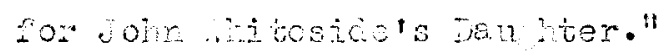

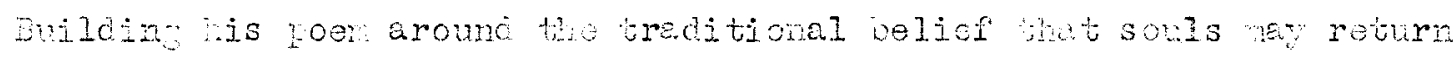
to the lenc of tie livine on hll sovls' int, Teats in turn calls upon a nuver of his locosed frienus and coments woon then brjefly. I quote a msage wich follows tio scene-settine introcuction:

orton's tio firsti call. Fe loveo strane thonet Laci new the suet extre ity on pricio hine's called Iatonic lore, And that to sinch a pitch or assion wrowet

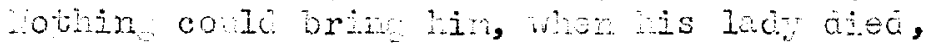
wocine for is love. 


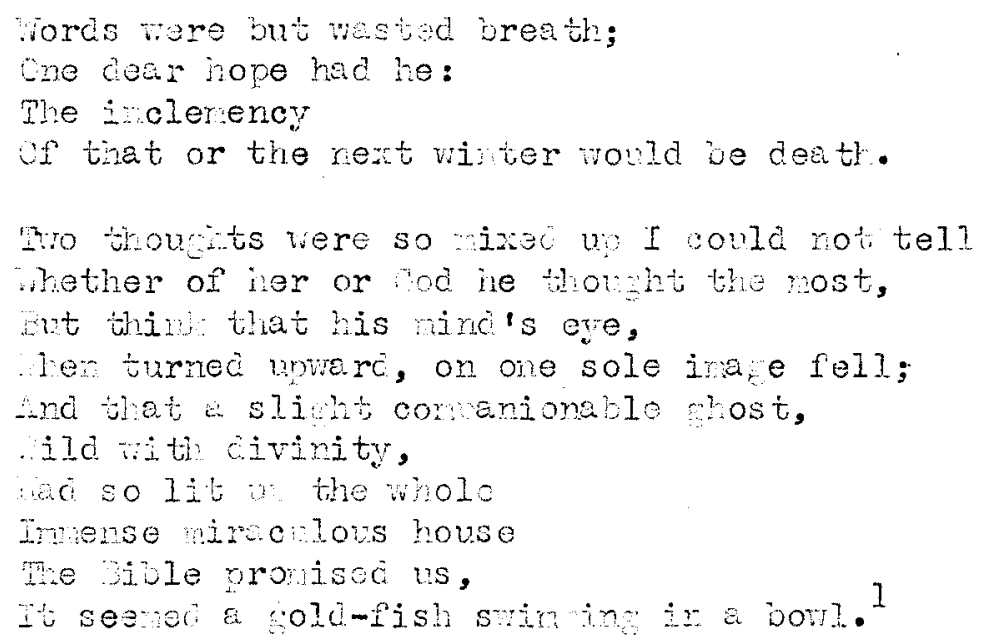

is entle section and animsical irong are juternoven lere into a gaturn of etrevely delicate and s.tila comctation. The noen attains

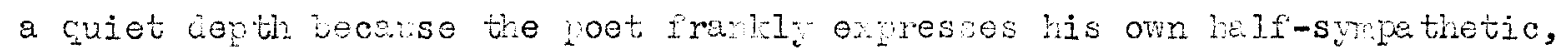
half-satinic attitude towarc lis friond's idiosycrasies and inconsiotercies. Where is both a deep understendine of is rriend's obsessions and a renetratine irony and satire as he whes his ton ve-in-cheel comparison of "oc's "imense nir culous house" and ta gold-fish swining

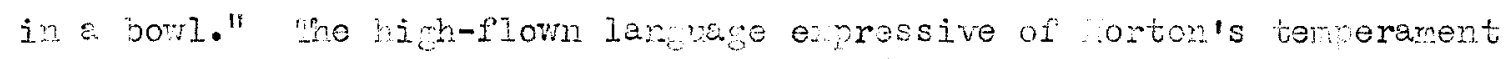

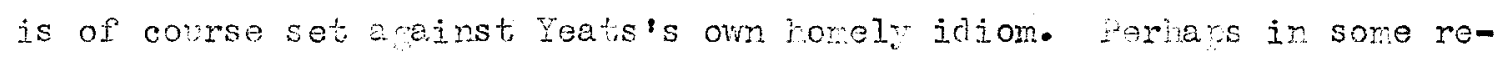
Specs the most imortent feature of the rassege ars the toral effects contributed by Yeats's ell-ewbracin, rellow sense of hwor and good wi13. Whe sane cualitjes dominate the poet's "In renom of ajor lobert

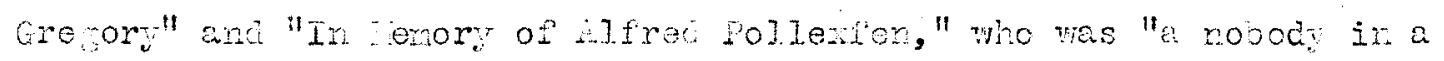
reat thron."

In ensom's "wells for jorn whitestels Leuchter" the irony becones a function of the almost inconorehensible, tra io aismarty between appearance and reality, the seeningl, imposiblo and the true. he poen,

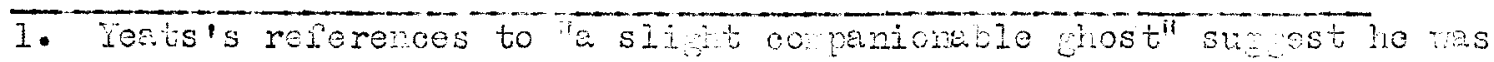

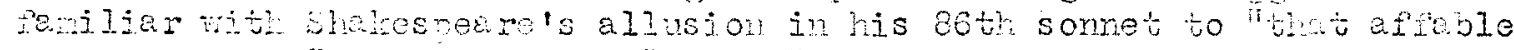
fariliar eost" wich rifhty "guled" a superstitious rival. The attitudes of the roets toward their eccentric acquantarces are similar in both poens. 
orevious?." referred to in illustration of pschological pro ression, is a mociern, rather sonlisticated elem full of restrajned symathy and tendemoss, non-satirical and ron-sentinertal, and vet, with a touch tiat is liglt and corfortably human.

In the Yeats oiece the irony lay in the poet's ambivalent attitude towerc his friend, a viemoint that was partlir satiric. wh in the Kansom pon the iron lies in the reat gap botween the idea of ceath and the newory of the vital, onersetic little girl. (A similar antithosis is found in the sane roet's "Jaret ain" and "yead boy") A deen quiet sense of tracecy is sugestec through the poet's use ot oblicue understatement and a restrained, almost impersonal tonal approach. This imcersomel tone, cheracteristic of the style of ransom, Tate, harren

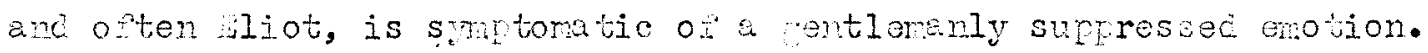
it is quite different fron Zoats's irnk expression of wixod feelings. It may seen to sore reciers pred on "yoicas" and "In ienorian" thet nemson is cealjry with deeth a little tho glibly in speering of the little girl's deep deati slee as a "orom study" and in exressing astoniswent and vezation rather thar a ore conventional grief. "Mroun study" is not an expression we use when we ere most serious, becense it seons to comote a lind oi amusement ancinomal familiarity as though the obsurver covid not tale the "brown study" ver. seriously. Indee? sorethin; of this bind is sugested in the poes. The poet, inowing the litble girl and her lively wids, fincis it dificult to comprehend her cieatl. Fer "brom study" astorishos and vexes her. and perlaps it wold offerd sole to kear of a departed lored one klyme so rimly propred." ather we would say that she looks as thourh she had just

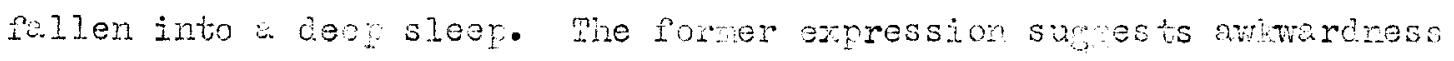
and unaturelress; the latter, naturaliess and ease. Sut the tregic 
awkerdness and umeturalress is rrecisely wat the poet feo's so intensel.y.

I hav noted that wit and irony are the chief elenents contributing to te comlenty and naturity characteristic of retah sical verse in the sevonteent anc trentietl contures, but that, guritatively spealins, wt is a coninant festure of the seventeenth century work, wile

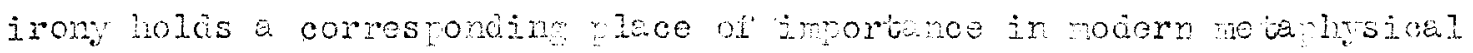
roetr. There is aloo, os course, a gualidative difterence, as I pointed ovt in an candrsis of the wit of Crasham's "n foitaph upon ur. crooke"

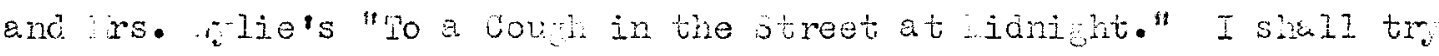
to illusicte a simjlar qualjtative difference between the characteristic irong of the seventeorth and twortith centuries in an exanination of

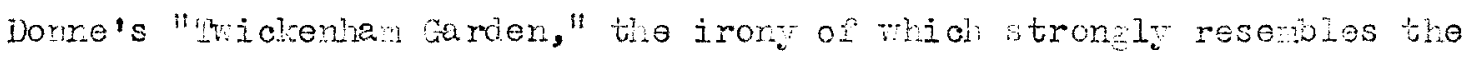
modern variety, and the concluine passeses of liot's "portrait of a Lady, treatin: a comperable situction. I quote the Dome riece:

Blasted with sims and surrounded nith tears, Zither I cone to seer the spring, ind ot my mine oves, and at ine es.r, lecoite sucli balis as esse cure crerytin; but o, self-treitor, I do bring

me spicer love, wich traisubstartietes all, find can convert mama to gall;

find thet this nlece ma thoroug jo be troult

true laredise, I lave the serient brougt.

Iwere molesower for ne the twinter did cenifht the rlory of $t$ is place, And that a prave frost dje forbid

Whee trees to lawh and rock we to mace; wit tit I may not this disgrace Snore, nor leave this excion, Love, let no sone aenseless iece of tis place be:

bale ne a nanlrake so I nay row lere,

Or a stome fountain weo in ont mear.

Iither with crystal vidis, Lovers, come, sna tale m tocrs, wicl are lore's wine, ind tro your nistress tears at hore,

Tor all wre talso that tas te not just like nine. Alas l hearts do not in gres shire,

.or car you nore juc ge momen's thounts by tears, 
Mian wy her shach owet she wecrs. o rererse sex, were none is true wit she,

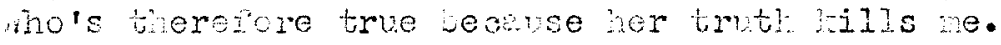

Me vamted distilisicn of the first stanza seems very ciose in many ways to a simlar self-consciows exprosaion in such pieoss as

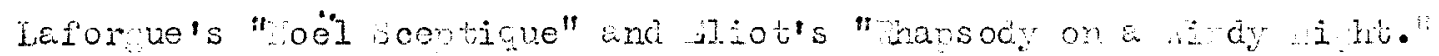

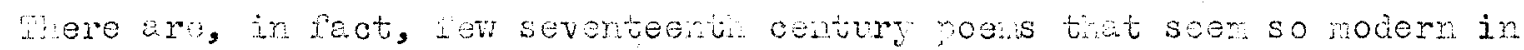

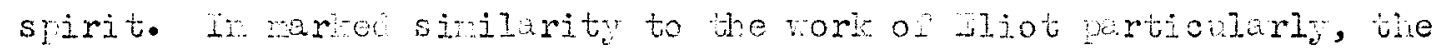
ironic contrasts ore ointed up shanly in the sntithesos betwen the sprina and the root's nood, the "sojier love" and the reli jous references to transubstantiation and manne, anc "true taradise" anc tio "serpenti".

owever, the ironic stroture ari disillusionoc tone of the piece are almost ertirel lost in a deft trunstion in the socond stenza to a nore itt and conventional true or anorous rens, and we bel thet

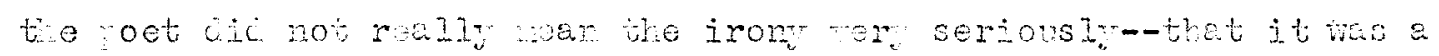

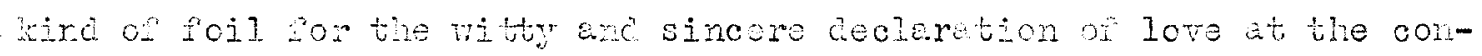

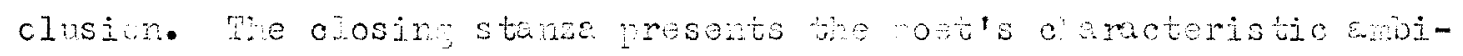

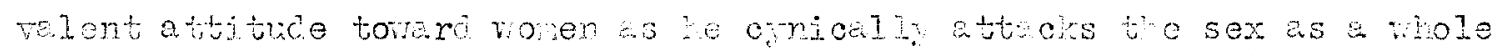

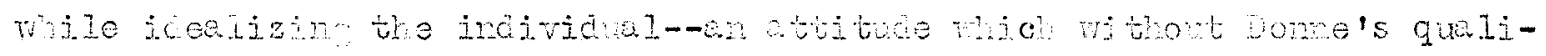

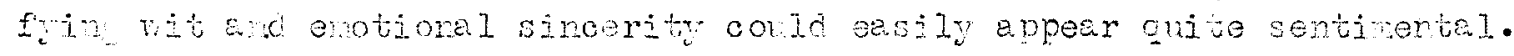
the irom a beas to be pert of Dome's techique of lomical comperity, Iivelr surpises, anc subtle incirection. Je shows an afinity for the poplar Jacobeen ornicism, 1 but is irony selcon, if erer, is tre nain

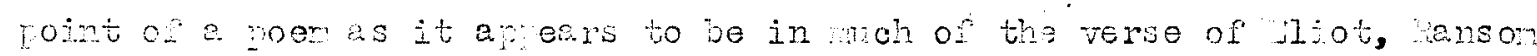
and others.

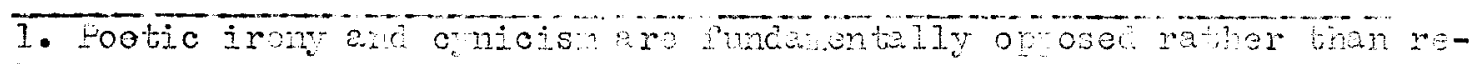

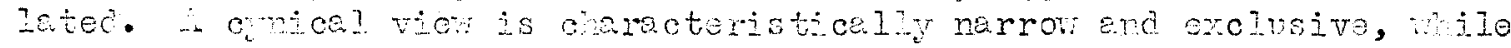

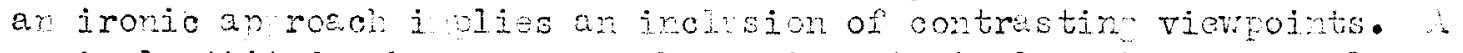

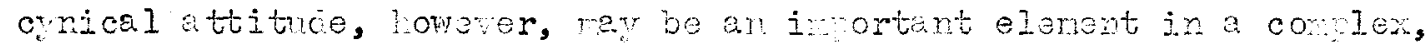
ironic contemplation of exerience. 
Irony assuries a much ore inorbat iunction, hovever, in such

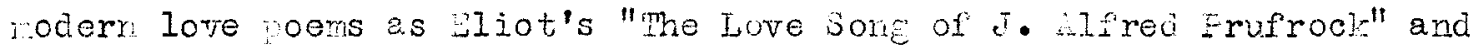
"Portrait or a Ledy," a piece about the parting of two could-be lovers caught in the intioitions and sterility of modern life. I quote the closine linos:

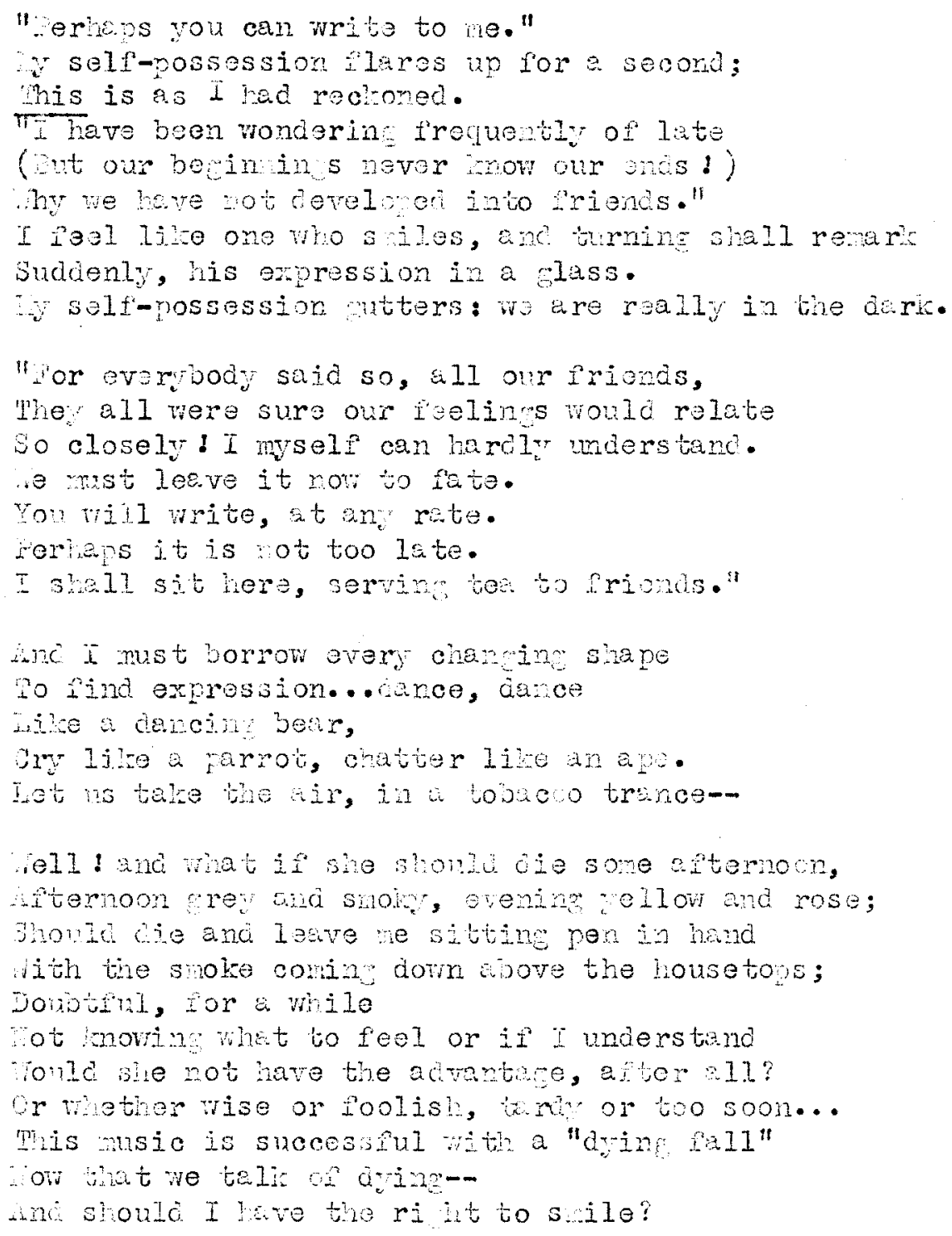

The passage is, of conrse, ouvionsly nodern in its allusions, idion an pro ression, wt we tre intarested chiefly in tie sunction

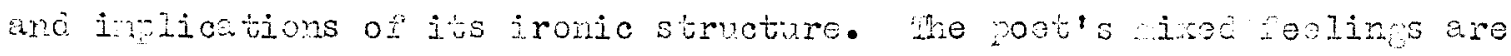

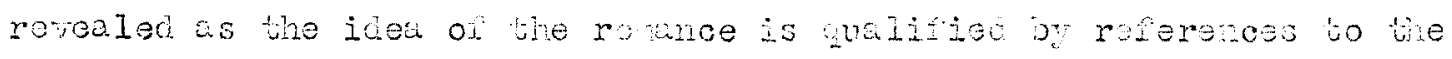

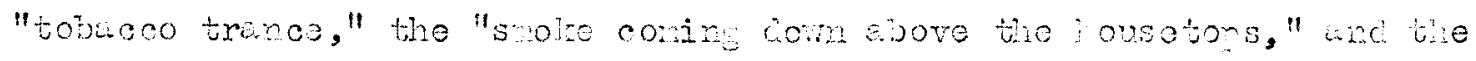




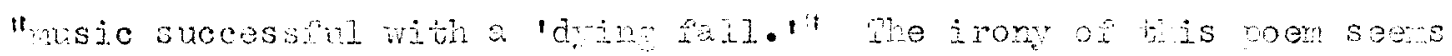

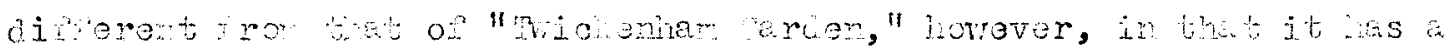
deeper basts and notivetion in the roetio situbion, it is rore serious

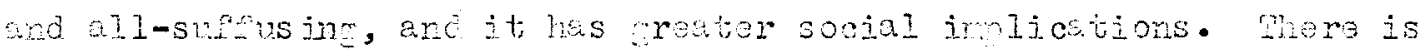

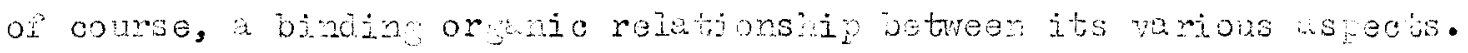
In the rome iece the irony wes chiefly is function of the oprosition betreen the suriz: ercen ad is om "suicer love," the otivation.

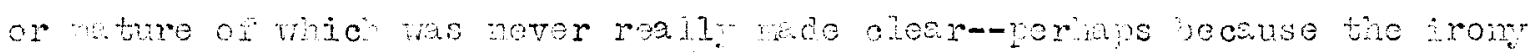

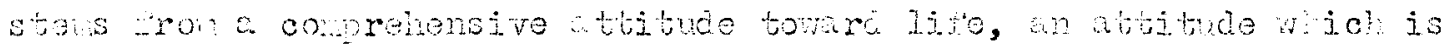

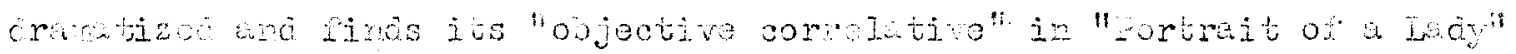

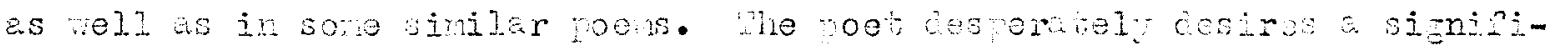

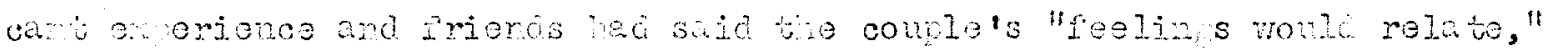
ont the ressures and inhibitions ol wodern life ermb only fustration

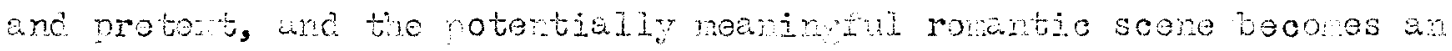
amourd tronic prod\%. In the condusion there is a suther sronic rem

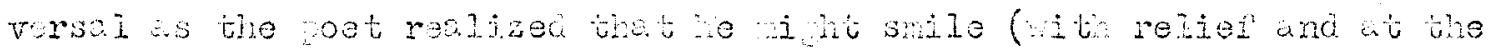

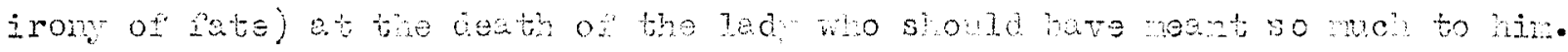

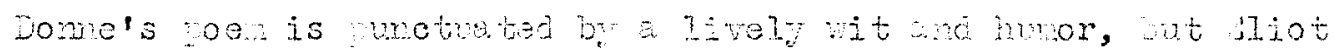

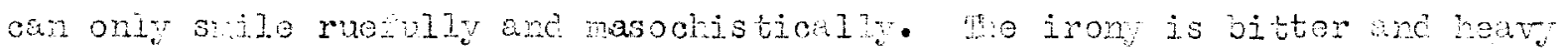

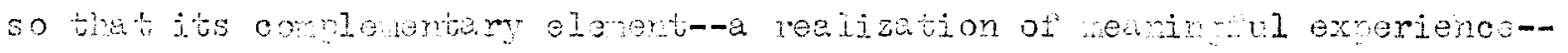

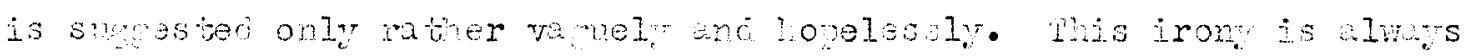

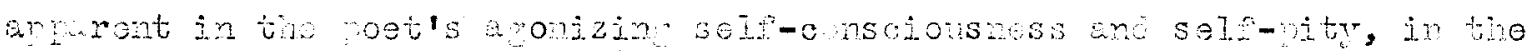

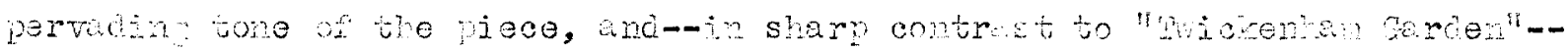

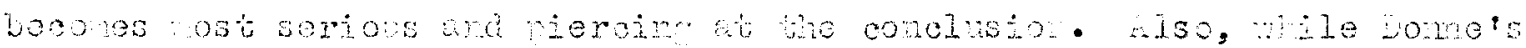

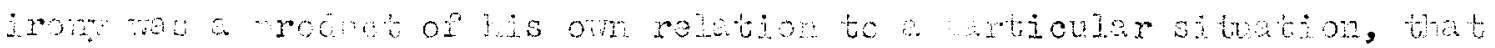

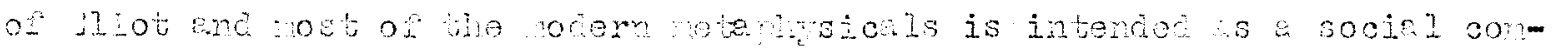

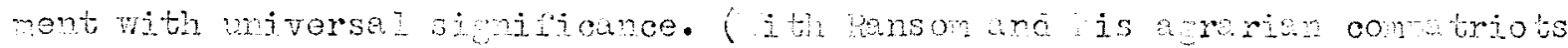

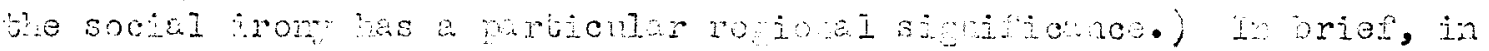




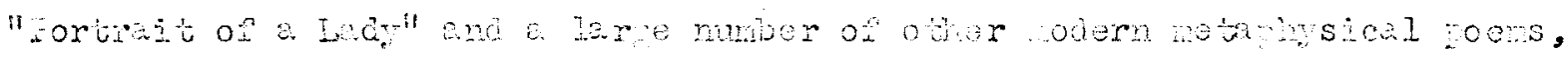
the pot's ironic stutement abot the metre of nocm sociot is at the core on the poen's reaning.

ats

It is nislesdine to thime of a hor and fast line of demaresion

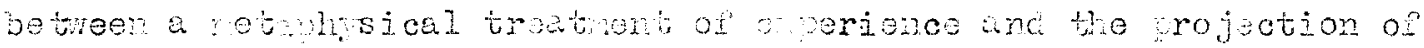
egerience in other stios of whitag, we a cture comle ity and a

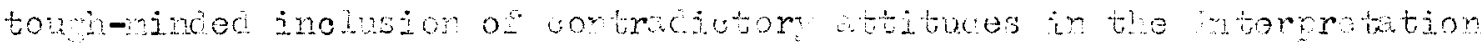

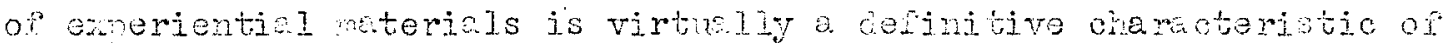
metaphosal ootry in the severteenth and trentieth certuriso vever-

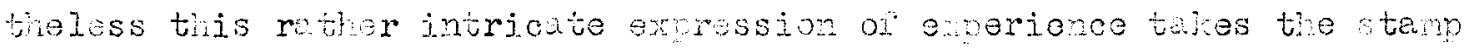
of the eriod in wich it appears, mo thero are simitiont difterouces In the interprotution and potic rojection on hum eneriance in the seventeent? and tuentieth centuries.

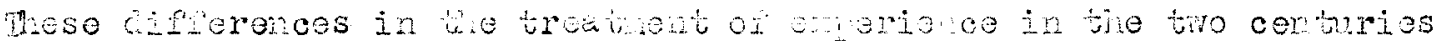

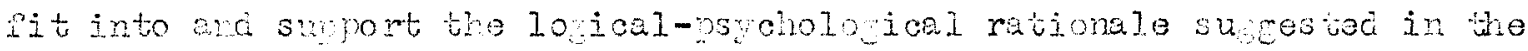
liscussion of nethocs of ro ression an rariovis ves of metahor. me

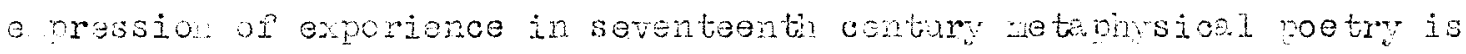

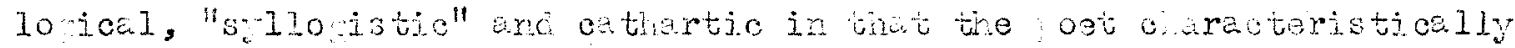
exprosos ois emotions rmankly ano without lesitution, ofton proboding díreobly to an ertinction of enotion in reely comitting all the rele-

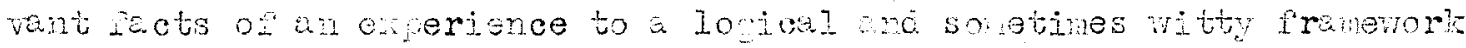

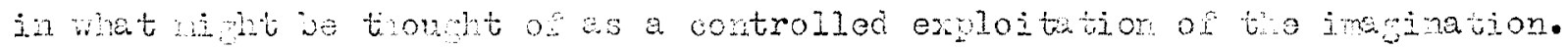

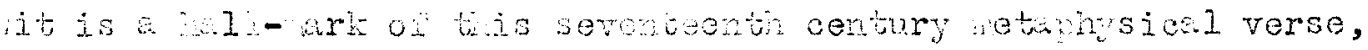

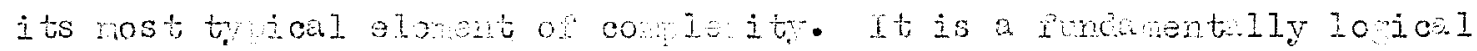
and intellectual. device in its use on atanor, antitusis and other tiure: anc in its function in shanin experience to orierly rarevoris. 
Fayfui nd Irez, it sans to incicute a rositive attitude, an acoevance of Iife. Inese unioring characteriotics wer seen in somentat diferent dross in such rieces as Donno's "The hea," "Loves proress" and "ine

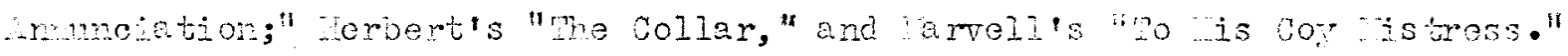

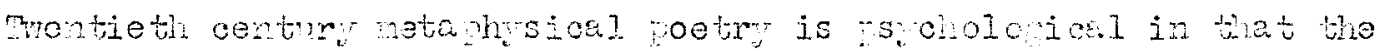
poet is chesty concemed witl the lus and low of exerience in the

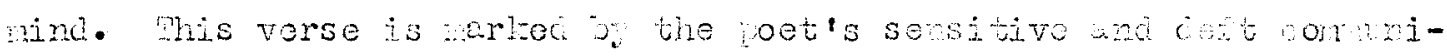
cution ot iztoto feeling, nuods and sujoctive states and by his subtlo insitus into enotional and intellectul coulicts. Athouph in tis modern verse enotjonal me terial is usullit nrojectec somewh lesis forcefully than ins seventoenth century work, the nociem noet frequantly exMibits finer insint into mances, shadiss and overtones.

The characteristic elenent of comleity in this nodern work is a

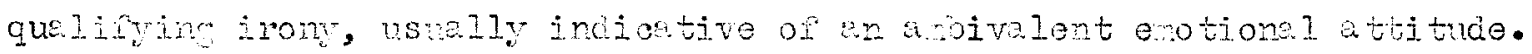

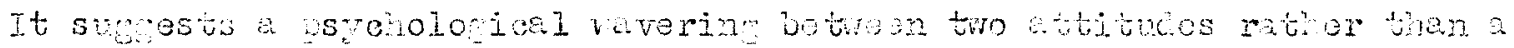

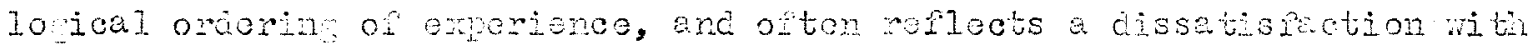

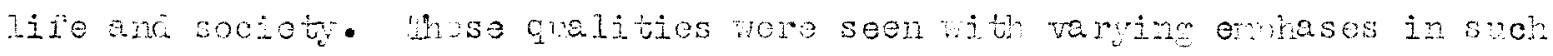

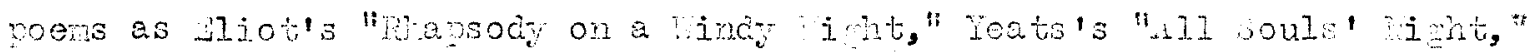
irs. Mlie's " o a cough in the street at ioni ht" wa anson's "Belis for coln hiteside's manter."

in historical approach in the examiation of the aimilaritis and dissimlarities found in the seventeenth and twentioti cuntury treatnent

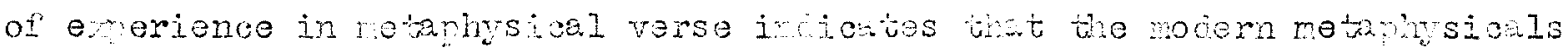
share in the heritare of the seventeenti contury netarysics no ts and

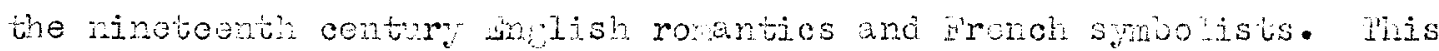
poetry usually sugests a sowententh century rogad for the inheront contrasts and complarit of an experience did the onotiona cenetration 


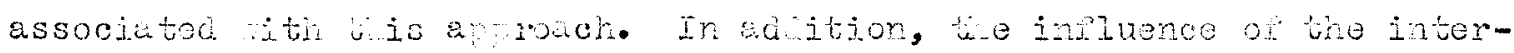

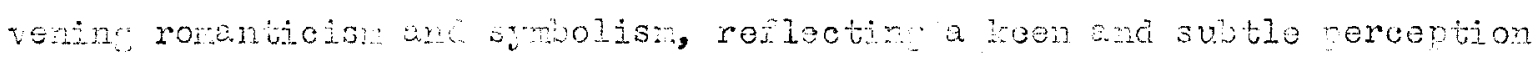

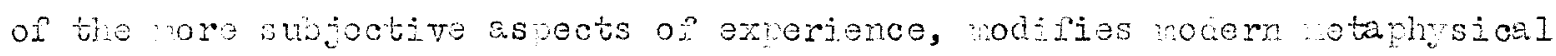

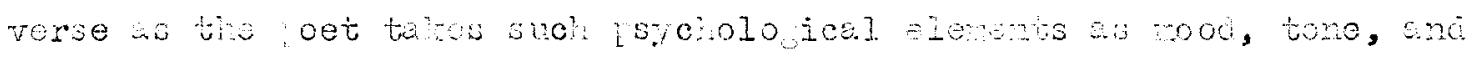

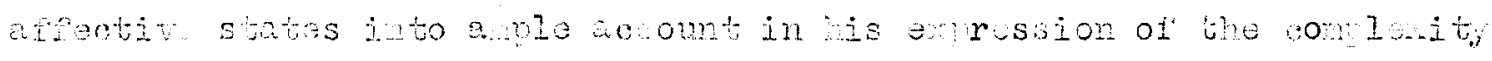
or hman e rerionce. The use of wit contines in ocern verse, but it

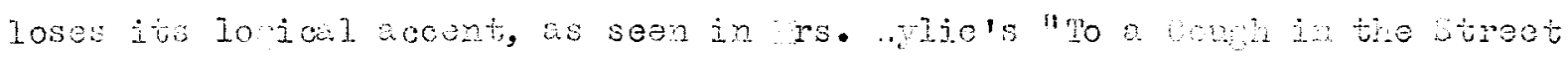

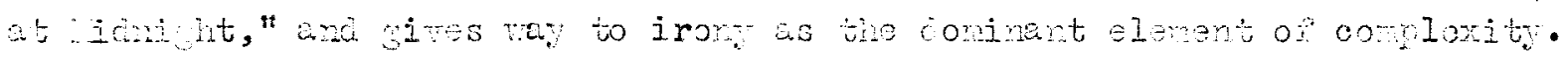
Irone, of conse, is no new incrodient in oetr, jut the ironic wonterpletion os odern retains scal poetr, a rollestion of the wonlicts confrouting the wodern pot, apgrenty has its roots in the rork of sane of the undish rowntic und rench symolists, as noted in the emanination

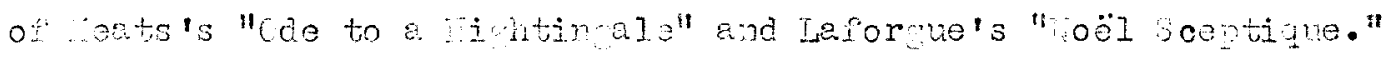
here can be no absoluses, no rinto or wrone way, in a poo's expression of eperience. It wonto seem thet wiere nust alwa se soe siant or "angle" in his troatment of e perdoce; and if he is sincore, he wil mite wat seons true and in wa the seons motural to kinsels

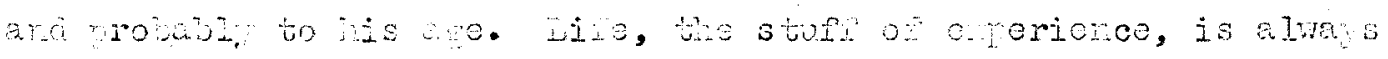
cantn, and so nut the oes in his injer rotation on enprience.

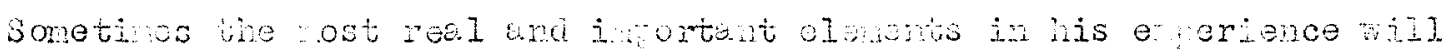
be contrits une comloxits, sometimes droms and noods, and soetines there ray de a subtle fusion of both. In cifferent periods the rot enphasizos differentaspects 0 . exerience, and each cifferent trpe expresis-

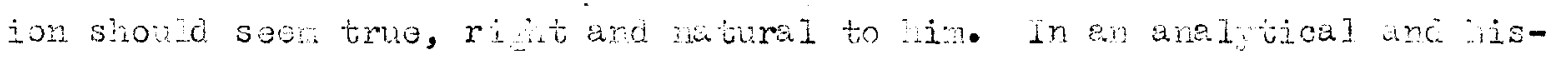

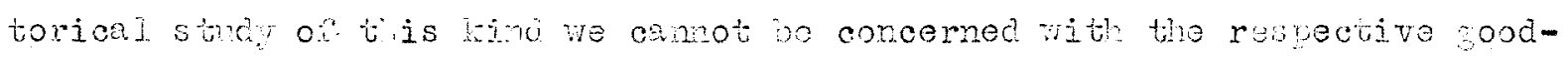
ness or riviness of difrerent poet's expossions of experience, and with

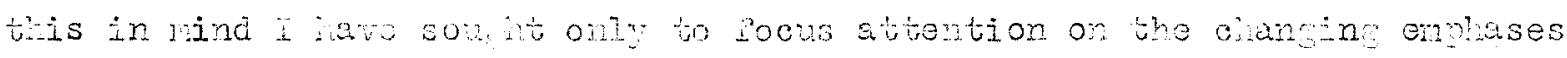
on different aspects of a perience in diferent periods. 
CHAPTER V

SOCIAL VIEWPOINTS 


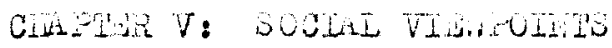

Loetre is not createc in a racmum. Certainly most poots, directly or indireotly, en ress towara their sociegr sna a e some attitudes mich are rey peatures of their nor. In this chanter I shell examine the viempints of seventeonth and trentieth contur. motaph-sical pots-thair atbibdes toward socioty.

For a creater alarity of teris I shall abandon temorerily the

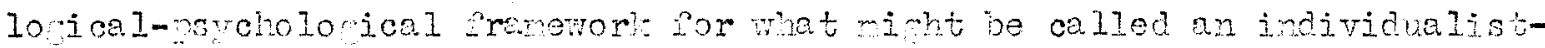
sociel ratonele, sucestu. hat the serenteonth century pot writes ns a vit, freo-rilline incividul and that the trentie th contury poet mitas of hinsely as a rether inlibited socially-conditioned integer.

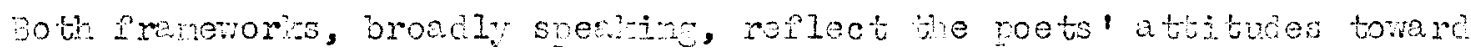

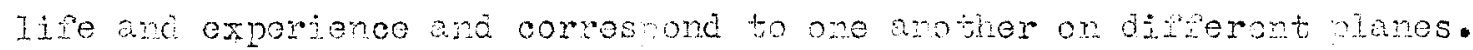

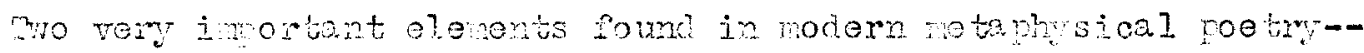

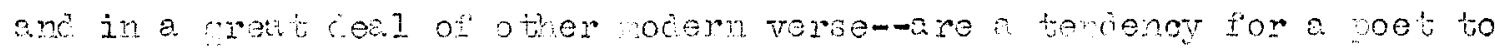
present a vorld hinhy conotroned by his om wohojog (as seen in the

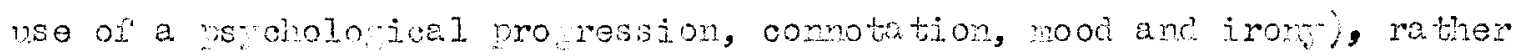
than a rore obtoctive riem of reality, and a bendenct to show noder. socteb impinim Itse another dimenson on evem exprience. Theso tendencies are not contracictor, however, but boti are apparenty functions of the nodern poet's discatisfaction with contenoran society Tis concern with society nay be thou ht of as tie obvarse aspect of his interestin s:oholow, or verhars vice versa. In the seventeonth century, hovever, the poet is rincicelly concemed vith a lo pal, ositive

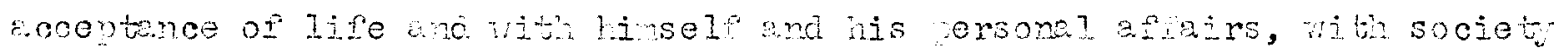
not apearin: as a disturbing factor-a somber strue, as it wera, stonding betreen hiw and his mistross. 
ie may, then, set 10 a rore conlete, ruber anivalent retionelo. The serenteenth century is cheracterizar by a lo cal-incuidulistic

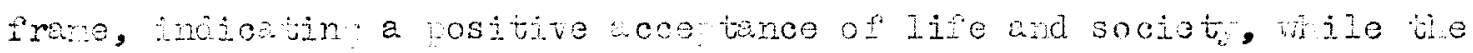

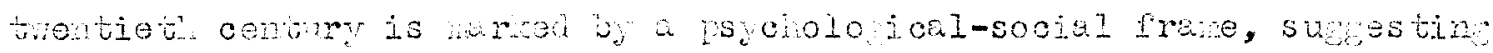
a raher nevatre disatispotion wibl jife and sooibty as indjoted, for arample, in the neav use of irbny in hocom metapirsicai verse. An

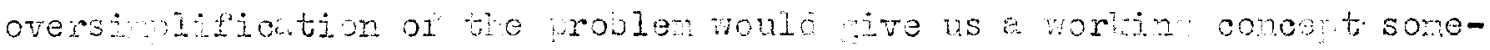

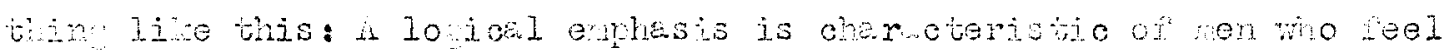

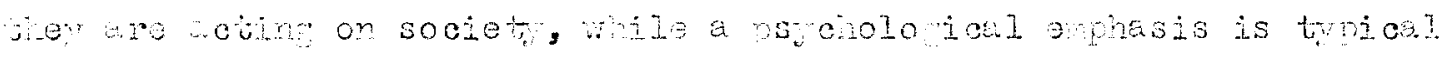
of ren wo cel be ajo jeir actod yon by socieby

.e aro also taced with enother somewhat naradoxical provosition.

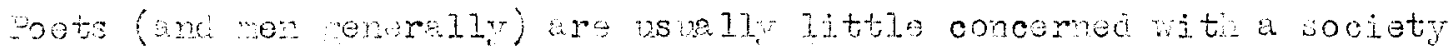
wen brey feej themselres weil adanted to it, and vem conoemed with

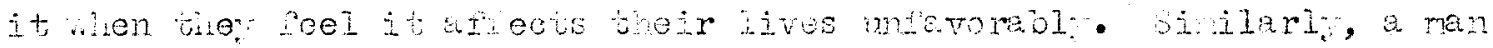

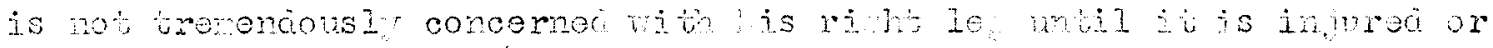

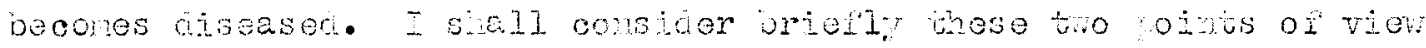

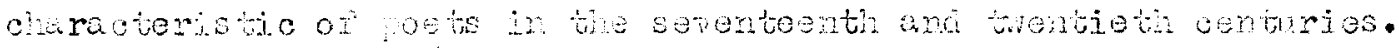

The sevateont contury iogical-indvical viowoint: the prin-

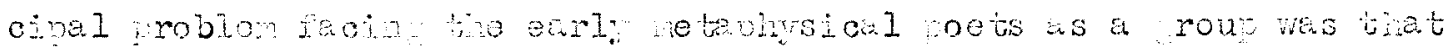
of their rolutionohig with God. The verse of ponne, ierust, crashey anc avell inaicates that these roets seldo, if ever, donbter the

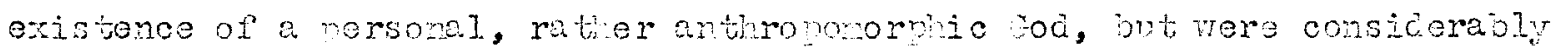
trovbled awut tie maner in wich the vere identi in thejr lives with the pot to

whe sorenteont centur pot is rinoinaly concomed ith himself,

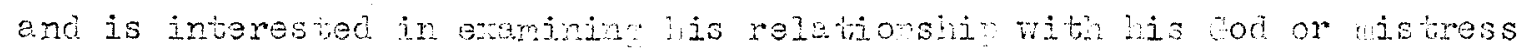

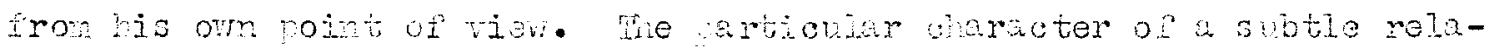
tionsty is not in ibself of a reat cew. of znterest to hin, and he 
seldom Iims any other persondity with the same clamty and force vith

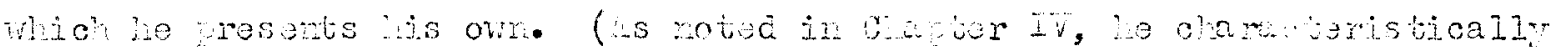
prenonts js enotions intensely and directl, without inizitions.) Ie

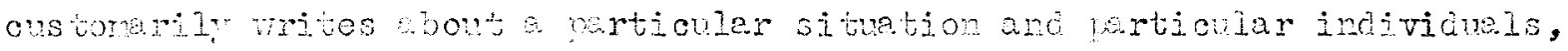

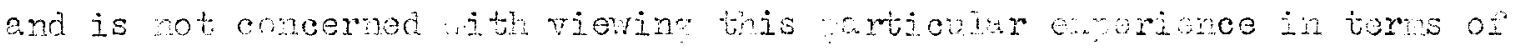

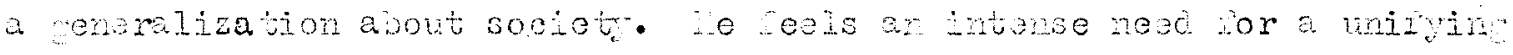

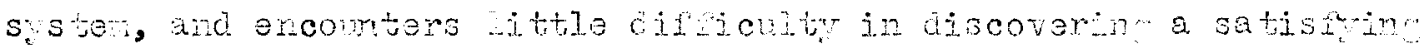
"ryth"--bo nse be tem in its orosdast sense. In his troatuont of humen

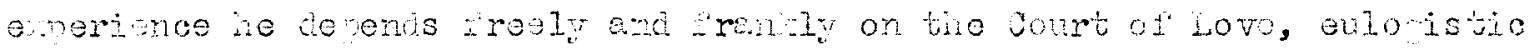

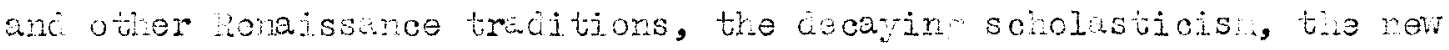
scionce, anc enocially his reijion. The seventeonth century metaphsioal poet is not a rofessional litteratar, and is verso is cheracteristicail persone m, minibited end nasculine, and intended for a linited and mitate appreciation.

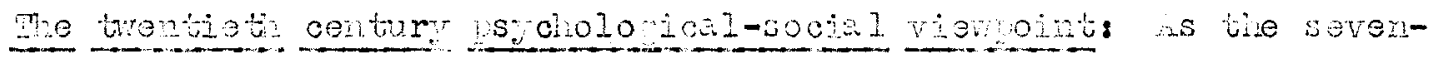

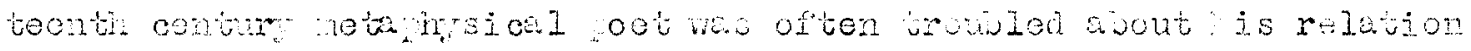

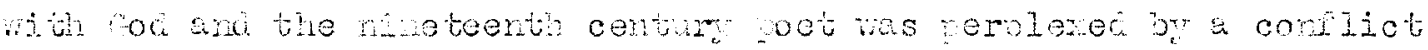

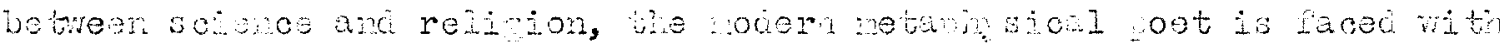

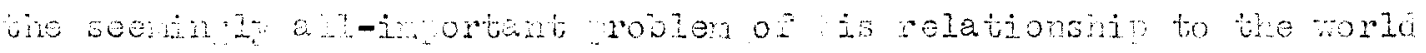
societ In wid lo litos and mites. The contemonar pots on the

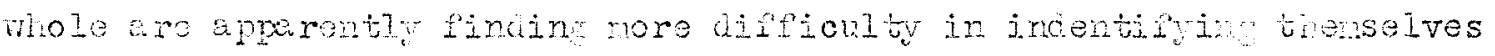

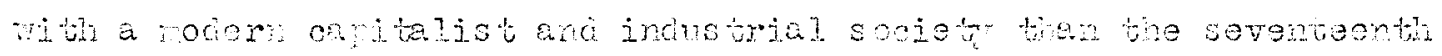
contur neta bicals encouterod in ationting to ake heir pesce Witir od enc tisenolves.

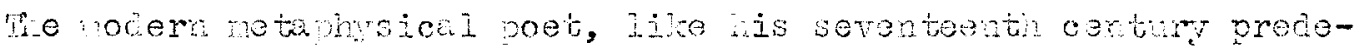

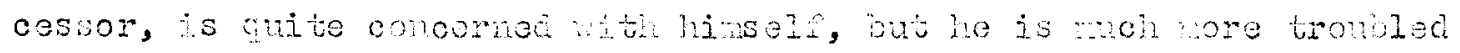

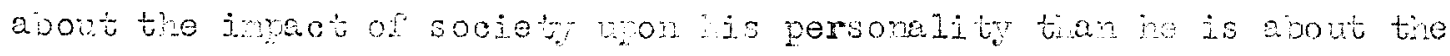

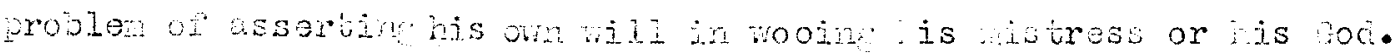


In contrast to the eariar coet, jowever, he does ajsplay an interest

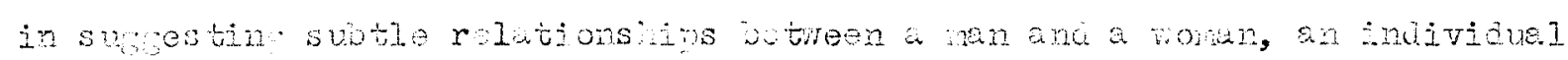
and societr or betreen himself as poet and a couple as lovers. ngain, he sometines deals with a comlex pet-man-womanociets intorrelationsho,

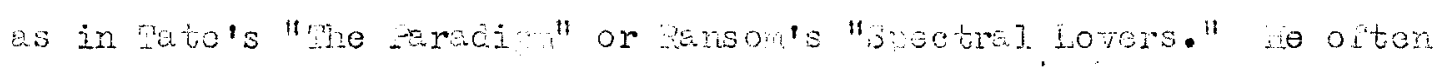

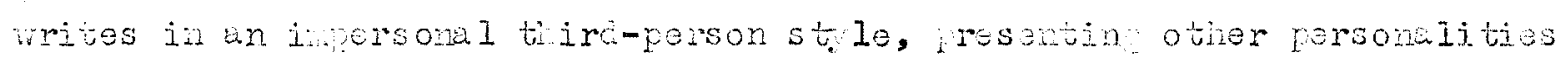

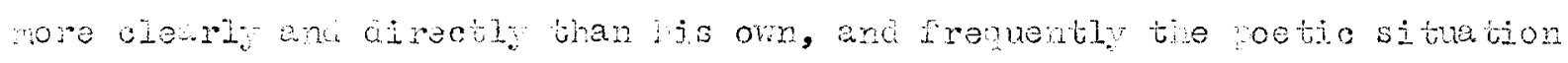

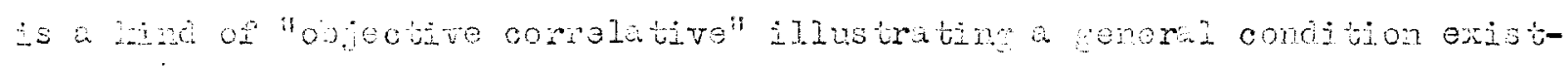

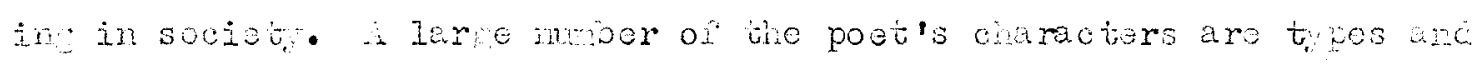

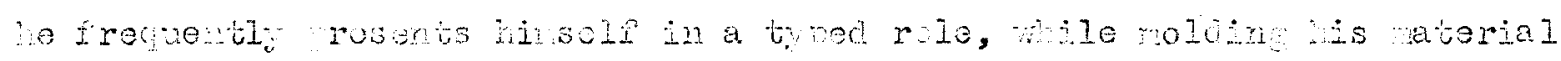
into a ittilo nocorn oarable about menta aivider sonsijility or a similer rrobler.

The noderi netavhrsical poet iso jeels a cesperate need for a sys-

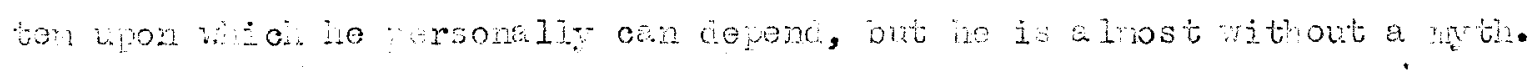

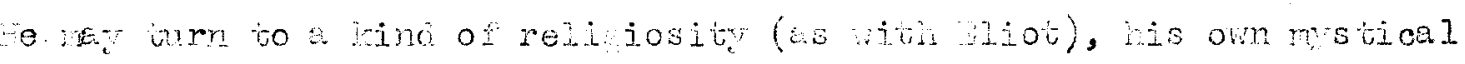
philosony and istory (Yests), or a new social iceolom (Awen), but he

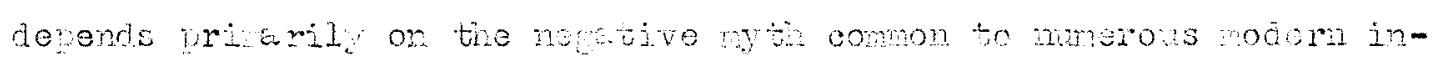

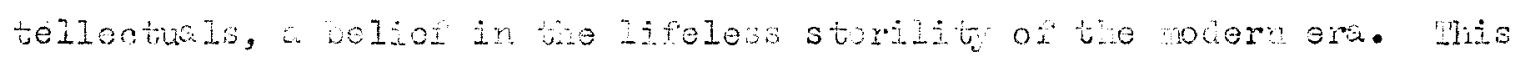
attibuce of rejection, or erhess psycholor of actetation, is seen in

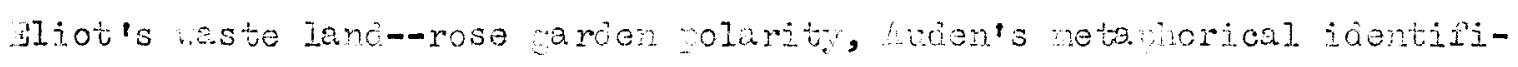

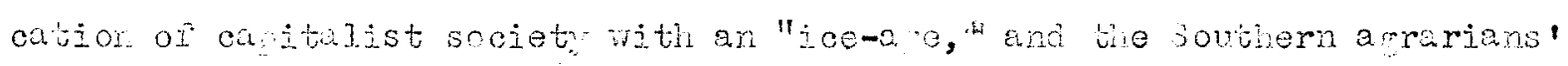

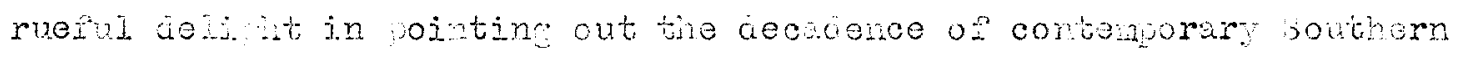
ine. The trentioth outury metaysical is a rotessional, seli-conscious

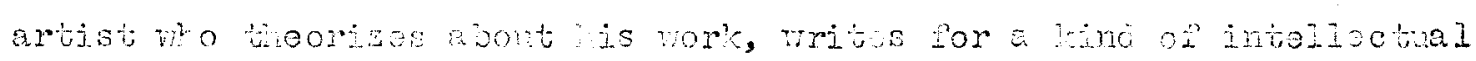

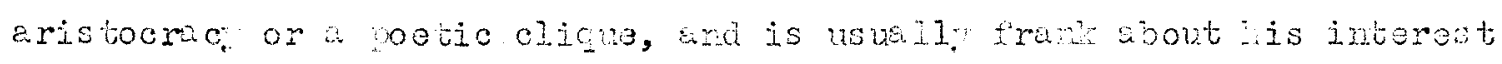
ir seventoont? cemtur bechiguos.

These charsoberistics of seventeonth and trontieti contur. verso are cleerly anaront in nost of the exm les quoted in the exanintion of 
diferont trestuts of ropesion, metanor and exweriontial raterial. The roet's concem abonth haselin in his rution to or is tie dominant the o vome's "yoly jom tos" ano otier late vorse and al ost all of the vere of corwert and Greshan, wile the nore secular arvel stors

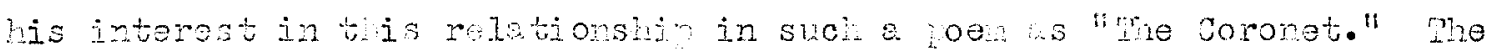

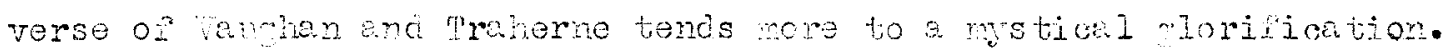

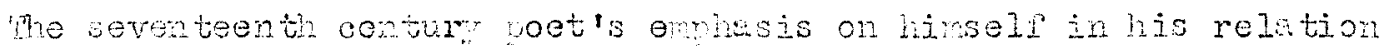

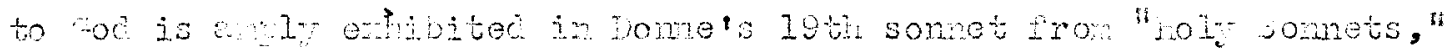

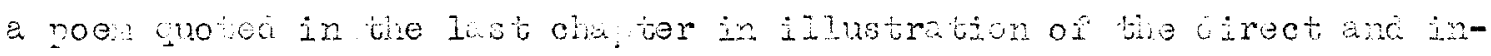

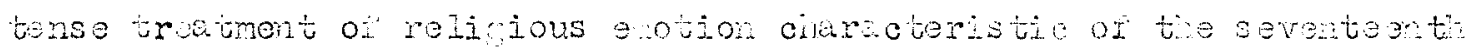

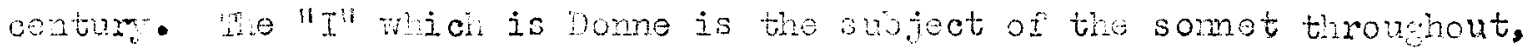
and tod is nemioned only once in the tilird person as the pot sneais

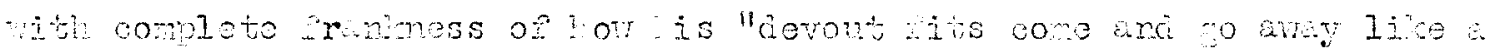

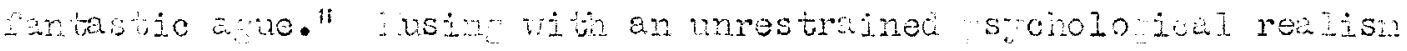

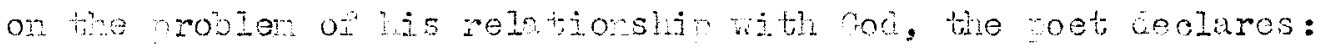

I curst not vior heoven restorar, and boy in prapens nu tetterin sueches I court od.

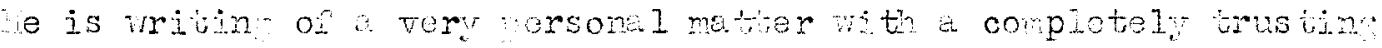
depencience or the reli jons structure, rulectin an atbituce in contrest to but of liot, ho in "hs wednese" ano othor later roens opton seons to ray to od as socisl onotesman and with a worle-wearr will to veliere, rethor than a fim and abiuin faith. Whe appeal of the Done sonet lies in its comincine sense of sjucerity, rather then

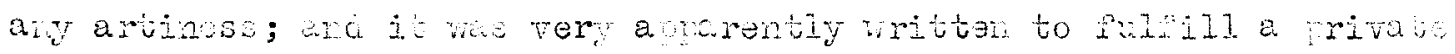

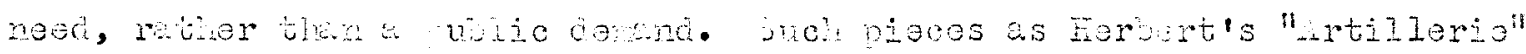

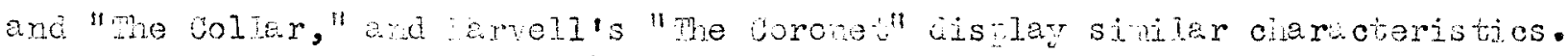

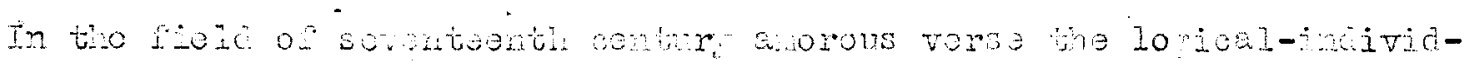

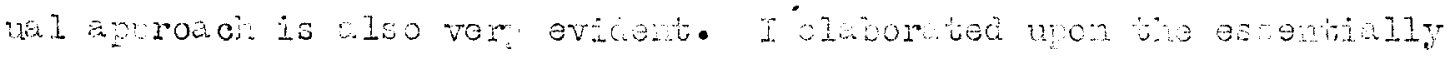




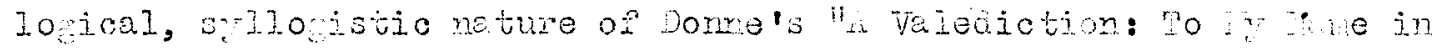
the inco" and "The Iea" and Mrvely's "To bis Coy istress." The most vital feature of these noems is the not's rojection or his ow personity. In the wadiotion wonne is chiofly concorned with resolvin" a confict wis om ind, and in the latter two niaces the

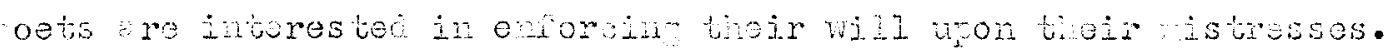

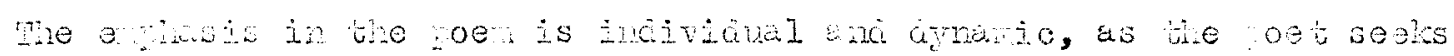
a morsoni resolution of conisot, hical or wental. we rore sutic

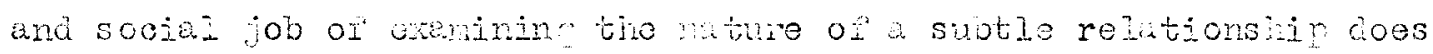
not carre en apeal of litie inortance for the poet. "Mhe Plea" wa "no his con istross" sre virtully whow eny cooial settin, es the pot is concomed only with himself end is lady the ieces were

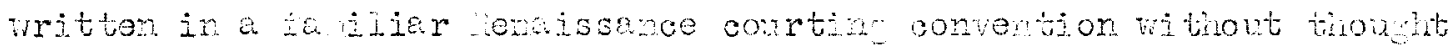
a viresurued distrioution.

is nodem soojal setuin, horever, jecomes a very ingifiount

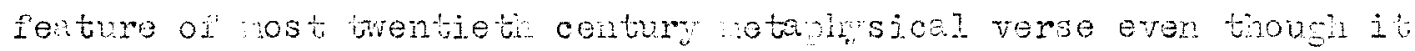
nay beer imortant stistic cheracteristios of seventemth centur

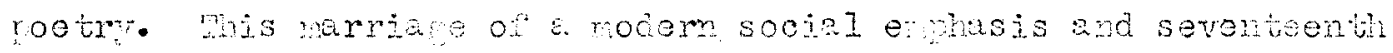

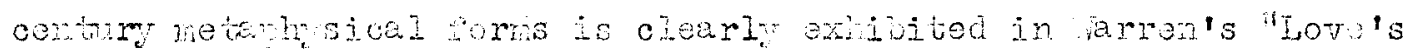
araise, in wioh the oot rovals his sockal viomoint in woth his sense on the intrusion of ociern incustrai life on mivite lae and

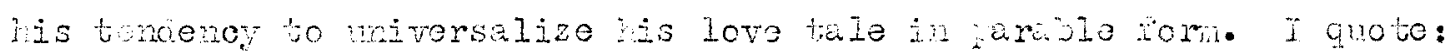

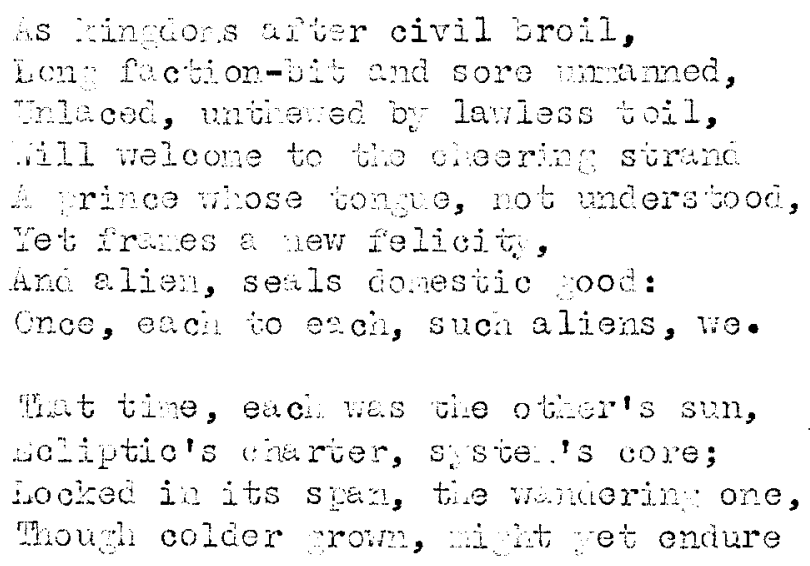


Anes unmumbrac, por it ed

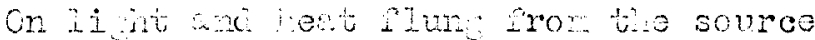

0 lint bat lit daro as it flec:

conter of dull as trononers.

o mncer tien to us it mos !

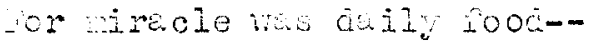

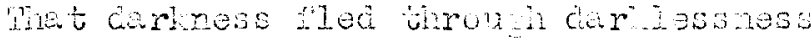

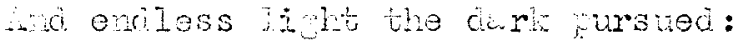

lo monder then, for we had lound

Love's rystom, tien still unsert,

mat substanco long in rossross bounc

ight und into love's acolicato.

Wen imole we comer-oheap;

And we, ilce the ignorate churriers,

mansedoct the careloss earih to reap

or invers our nos recsous ores;

or Itre tive blociace asons wo

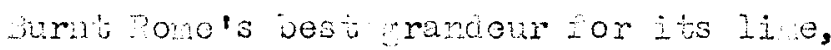

wa tor Geir idatorn hovels thew

Down noments of nobler tuje.

.e did not lnow what norbe we omed,

or now wht dwient atosmere

e brextred, wo deily tion ostroned

- monied e thet, row bomet too cenr,

is put ironic rosicive:

-s gout fans art tamishoc vest

enind the matrol banismit wo,

for at and bad, jeb subtroe waste.

Tret a Il tie world popontonte

and oyful serred, dia put consent

rict all unto our percen state

te innocence was imocent;

nad ali on eas azle roted

Thit iow, unearoc, nerturbed turns,

Tor jo soult fo then mon we loved,

s sron to ine ranet yearns.

hit wo ha seen tie tur us o o

Gi...ser. soore in tie aj gith,

and watod, of frionos, the ajicas

wht stain, like smole, tho das sound int,

oir ucorous, hom acid, then

ow rome ples: on the somier rows

iil rot eaross tive estute on men.

Wha wred, rithin, tho invara sore

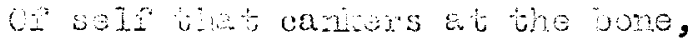

conte: it ol ver, Lov we bore

Anc atred on to oon onee mom

- so wemimess hs beeome on strometi,

me stroneth, conusor, con but peject

Its opject, so tia is at lente

itchne anc sumbse, each otrer intect. 
Lre we but irror to the woric?

or cioes the wordo our rin realeot,

or is on garine veout s oiled

Jut Dr the lass' flawed le ect.

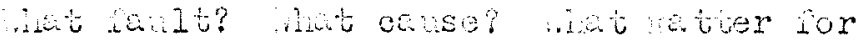

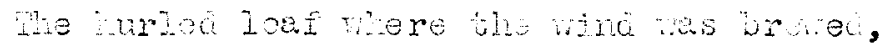

or metrer for the pentit who

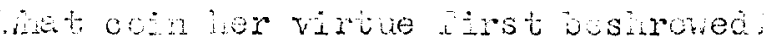

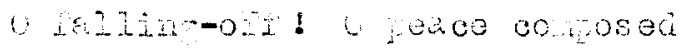

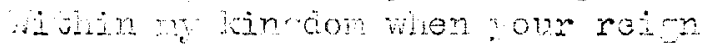

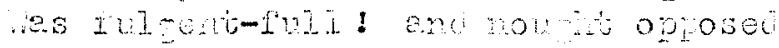

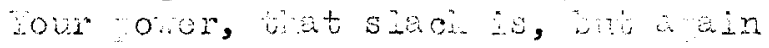

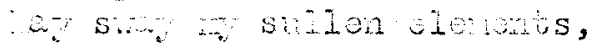

whe ine anjitjor to its juce.

nat hopa: for t: ara are bestemonto

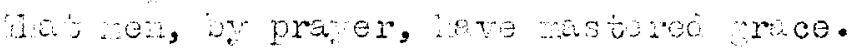

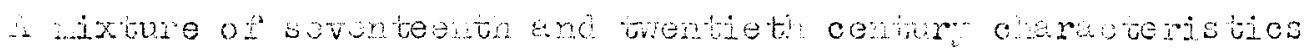

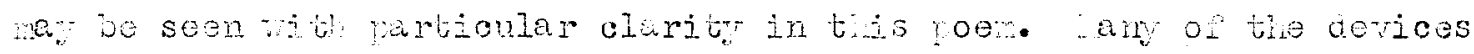

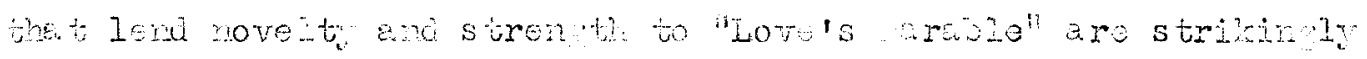

simlar to bose tounc in sevateonti century otahojcal vare.

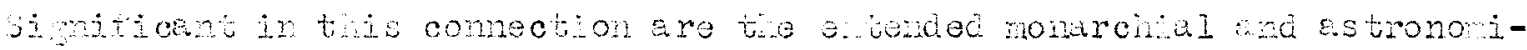

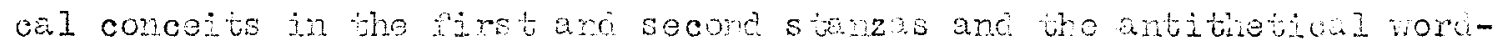

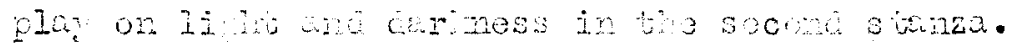

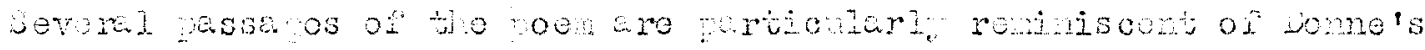

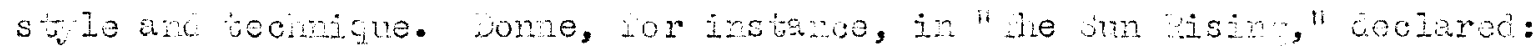

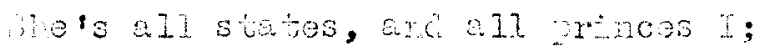

notitin olso is.

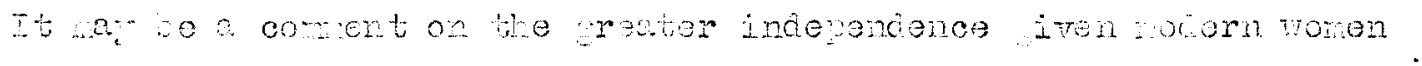

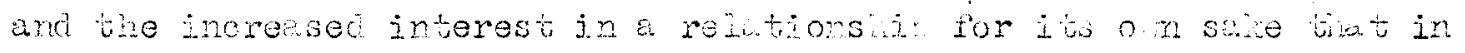

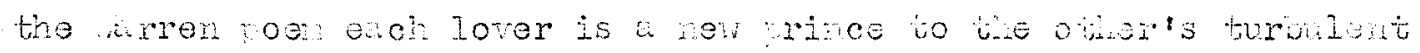

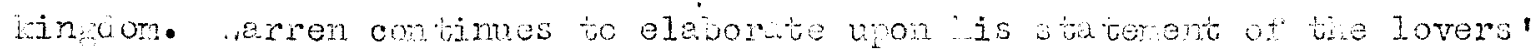
reciprocal wations:

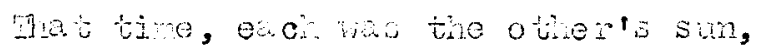

delj totis orarger, us te.s core.

It is interestin to note but there is s siuidu ine in ponne's

"The Good-forrov:"

Lot us ossess one rorle; each ond and is one. 


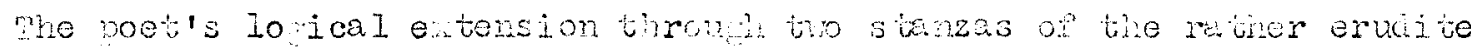
astromo tcal metahor is also su astive of sevententh conbry patice

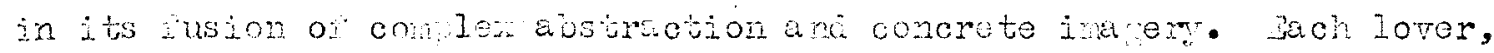

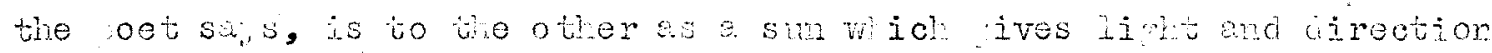

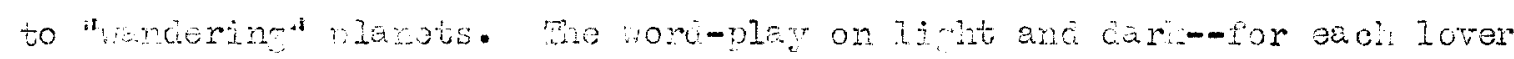

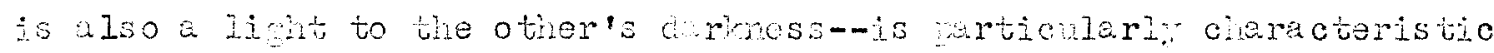

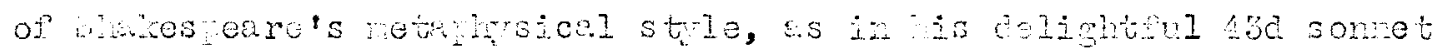
("Whon rost i whin, tien do rine eyes best see" ete.), anc of arahew's woris, as in "In the horions tpiphanie of our word rod, a fym sune

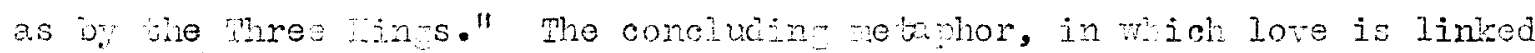
With rolinion in opposition to muane societr, recalis a similar notehorical icentidiction jn Dome's "The Canonization" and other pieces, mite the nse throu hout the poen of netaphor we antithessis and the complaxity of the ettitiue exposed are olso sugestive of the sevanteentin century strle. In fact, the poen resenoles seventeath contury netainsical roetry much nore olosely than nost modern verse.

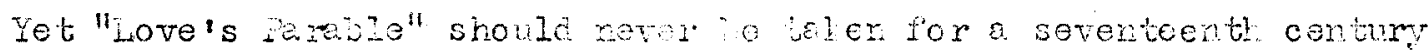

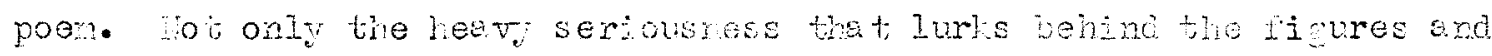
the ratior bitte: atack on wodem life and societ, but also tre ary,

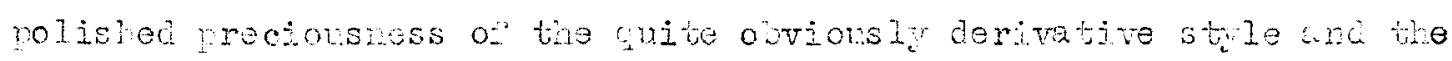
quiol ironio tone ervecin the whoie oer pojnt to iss brentioth cotur antorstin.

Wom litile interpretation is neoced to see thot the roet les a very

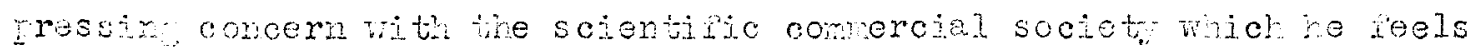

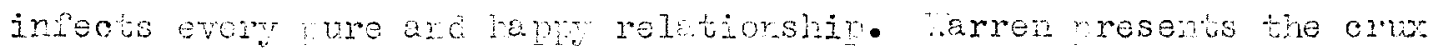
of the poen ene of the chief prolen facin the twentio century notaphysuel poote as a rom men he asto: 
or is on samb beauty spotieo

at by the lass slewer defect?

After cerotin the first bree stanzas to a troatmont of the reationsin jotween the bo lovers, the oot in stroles joth bolc

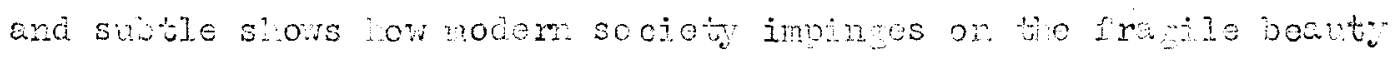

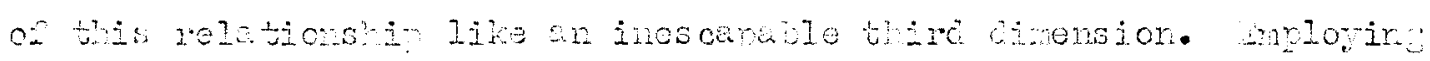

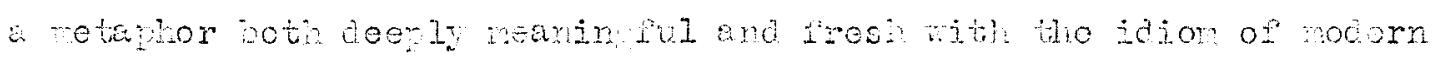

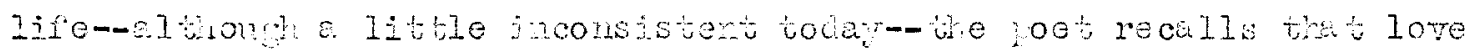

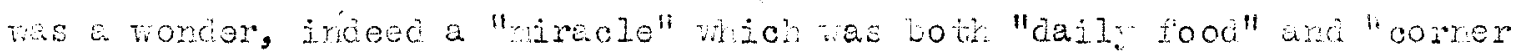

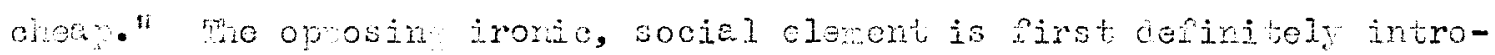
duced in the cole scientinic reperence to "Iove's acticent," ss ophosed

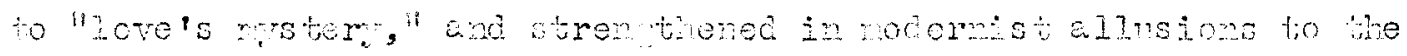
"Tlochece wasons" and the "inute resicue."

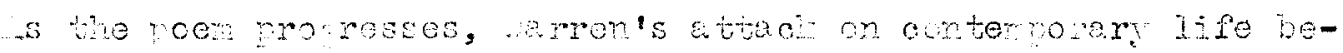

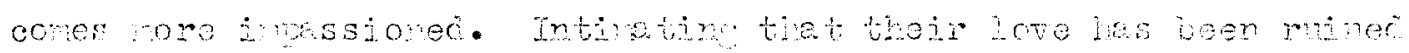

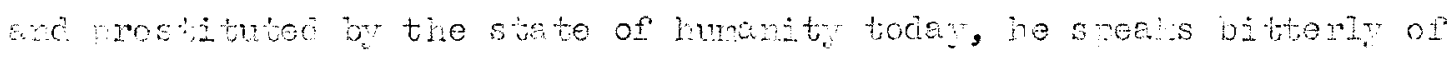
1stringen:

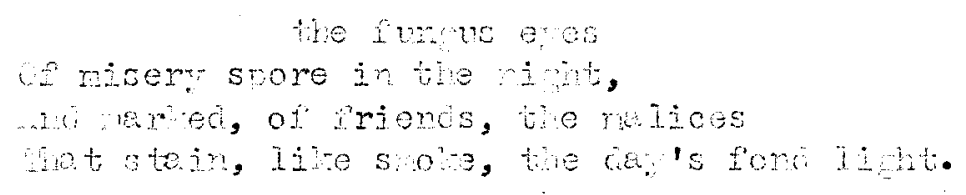




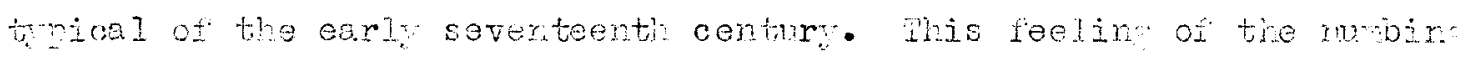
rressuro ane restessess of modem ljte is also whessed iz such

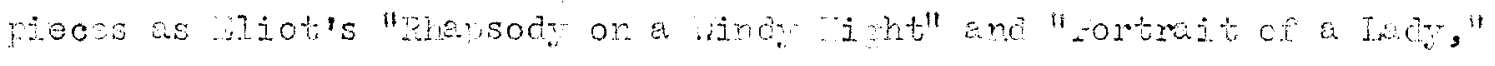

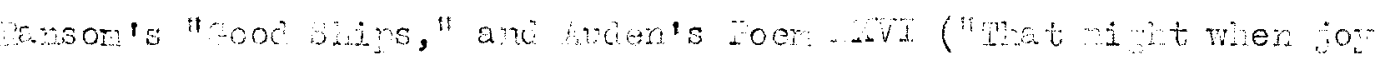
vegn,

It is simpicant that the roet cairs the piece a amble, for it

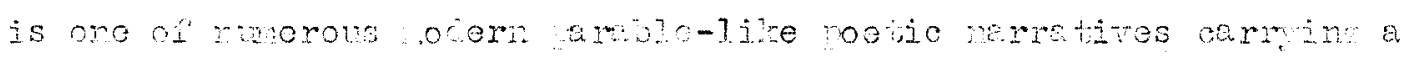
litile lesson or ecitorial coment on odern itie. Whe tale is told in

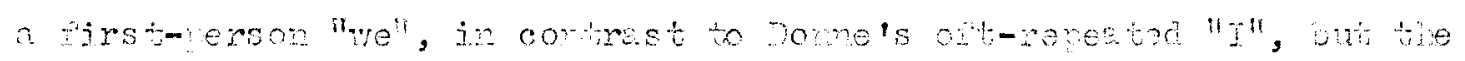

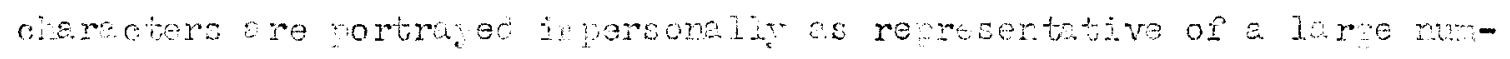
ber of senstive rodem lovers. Me conchision of the por is temaerly

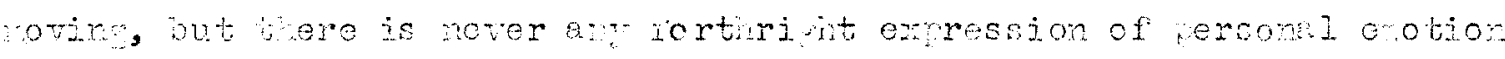

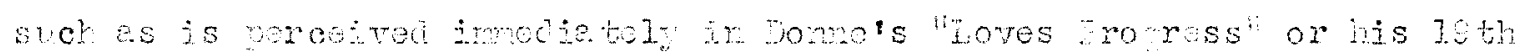
"holy somete"

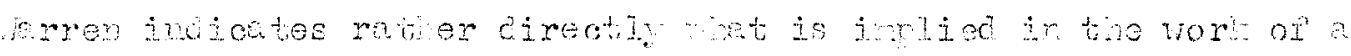
rejority of the ocem oets-his doncerce on the new tive inteliectual

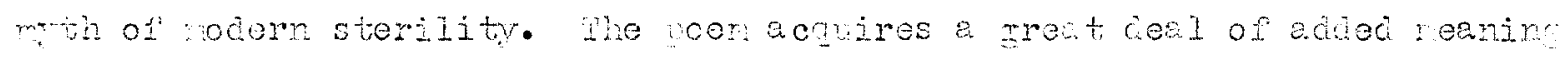

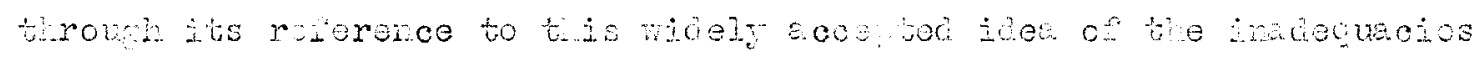

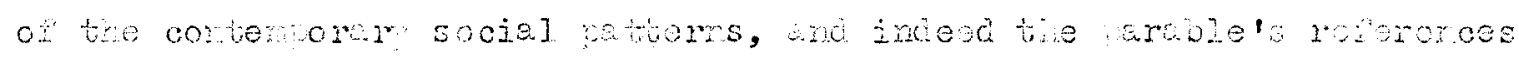

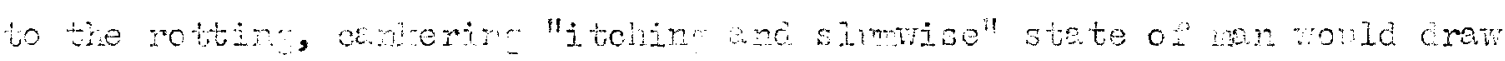

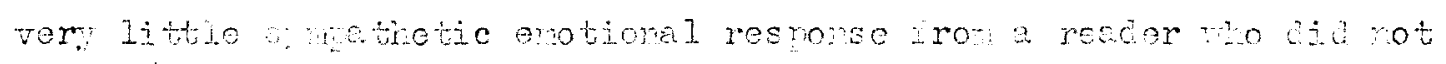

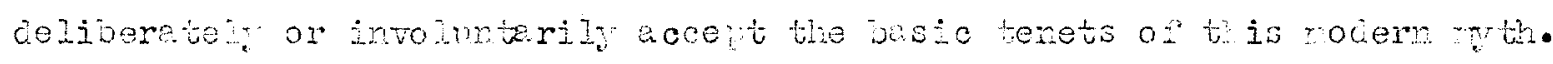

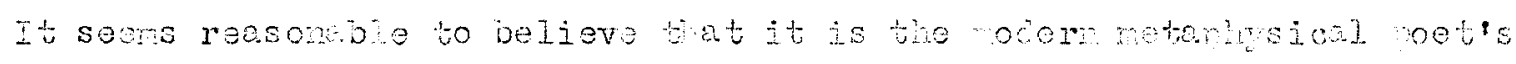

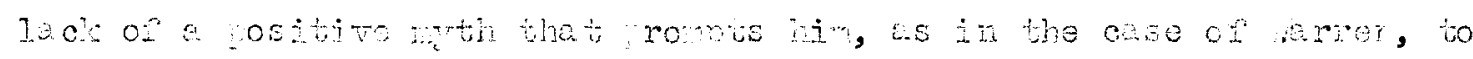

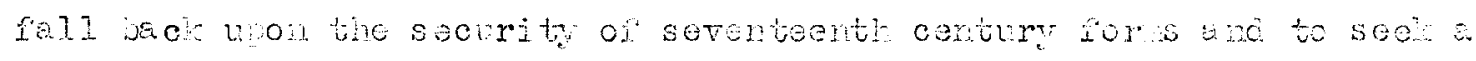
certair sociel jotidution in are li terar, nore pulic sble.

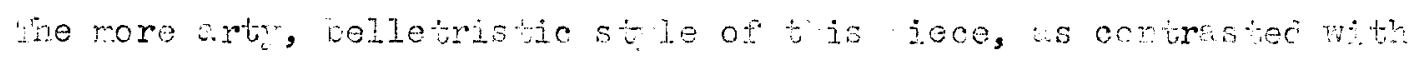

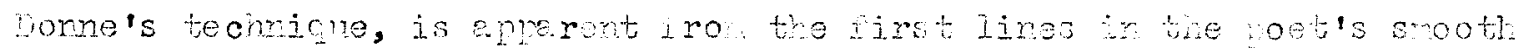




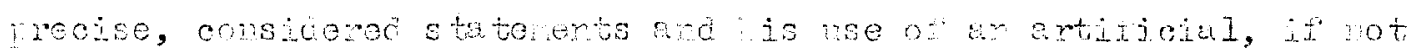

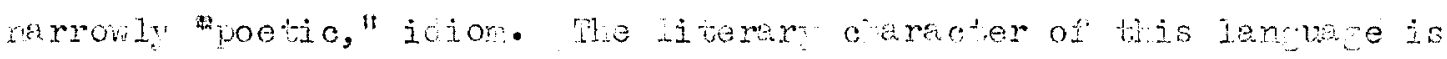

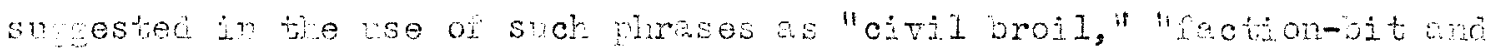

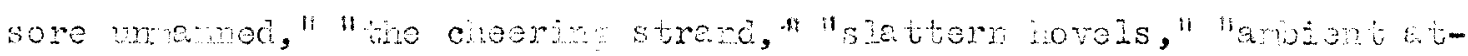

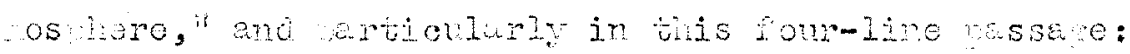

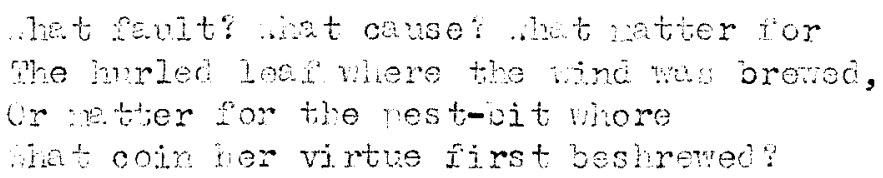

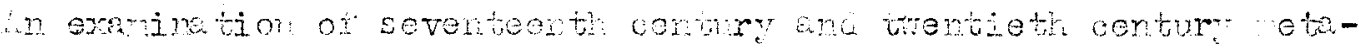

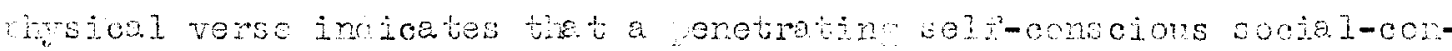
sojonsoss is essontialy a nocem, henomenon, retier than seventeenth

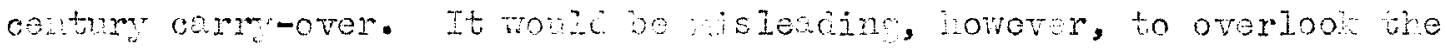

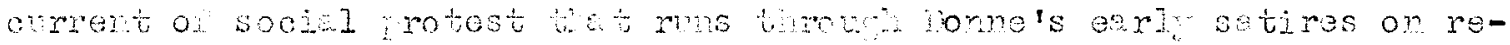

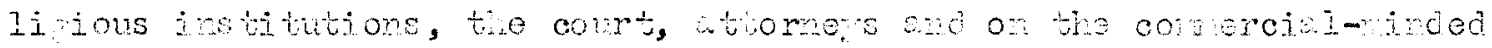

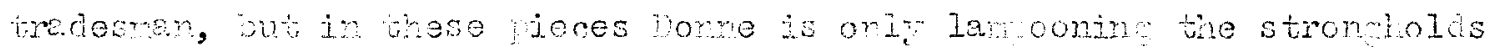

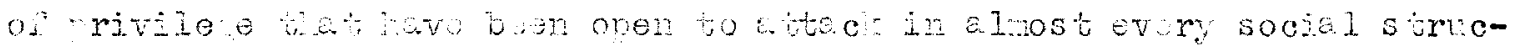

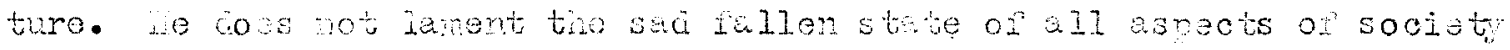

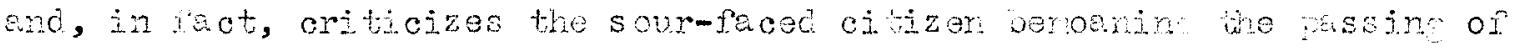

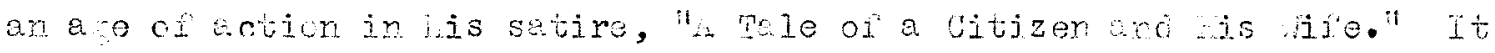

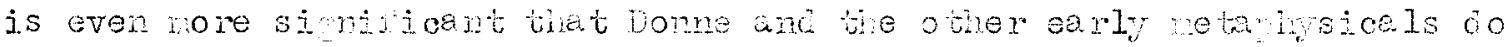

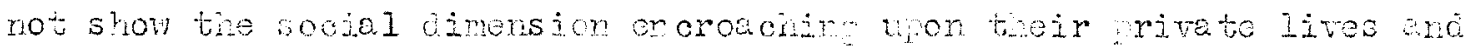

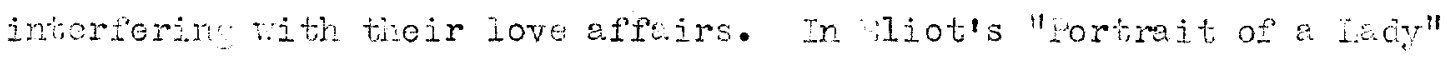

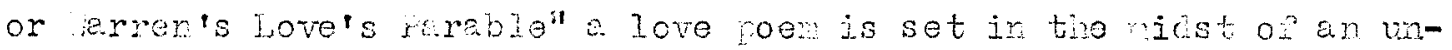

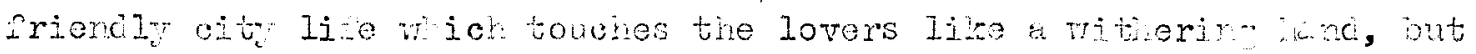

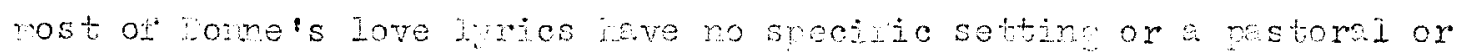

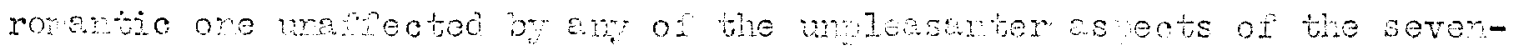
teenth contur sooiel pettern 
It is robebe, howerer, that the twentieth centur netarirsical

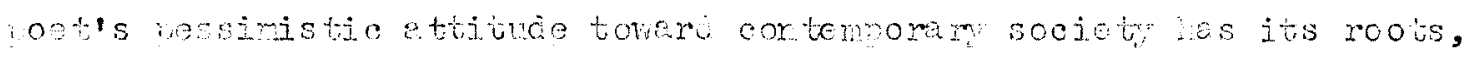

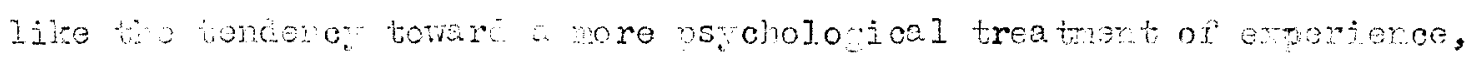
in rineteonth contury romanticism, the develowont of en imorsoral in-

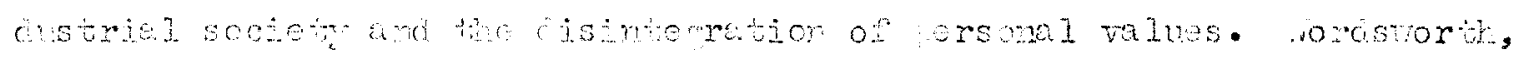

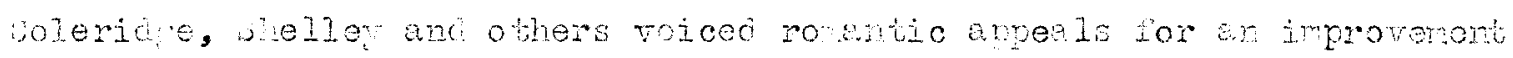

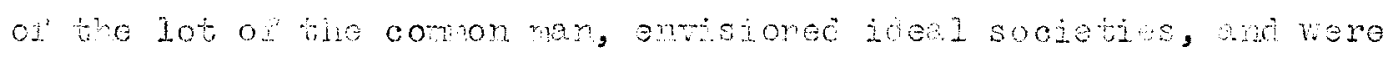

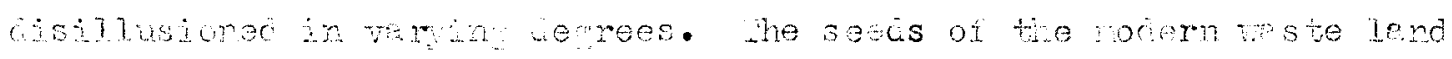

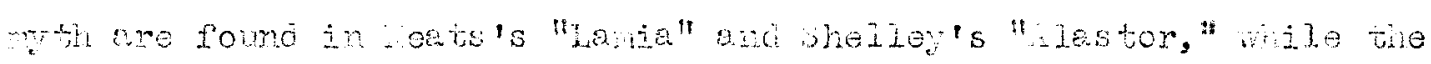

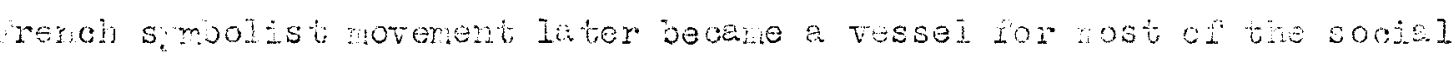
dissetiffottons of the cay, reilecting mer's tealins of irsiminiwnee in e nociern socieb.

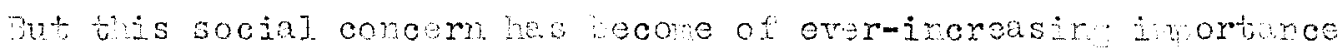

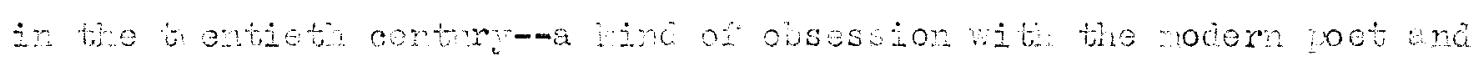

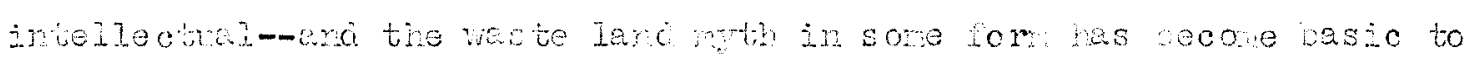

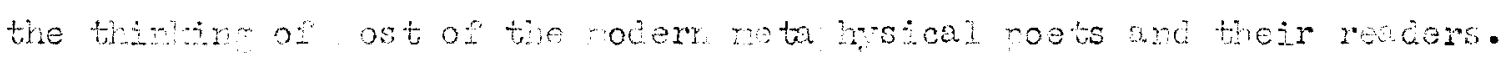

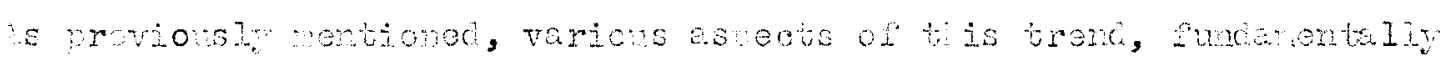

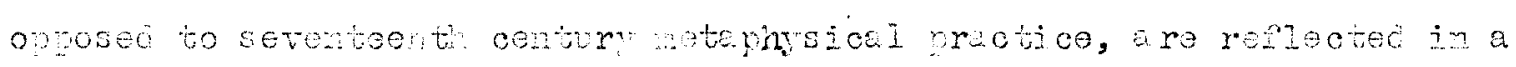
new enhess or porom 1 pietjonstis, a pessin interest in societ-

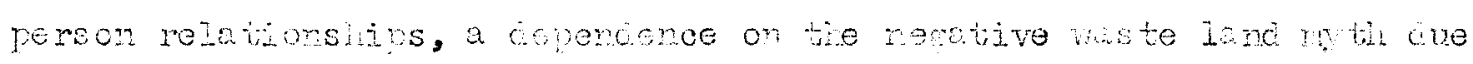
to the lack os a rore fruttul ireweromis, the use of mersonel, uni-

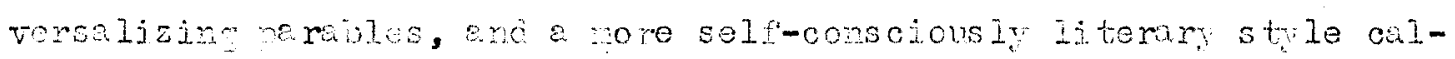
culated to win bo oot wojo aprovi-and probabl a leotin o. selt¿voticiotion.

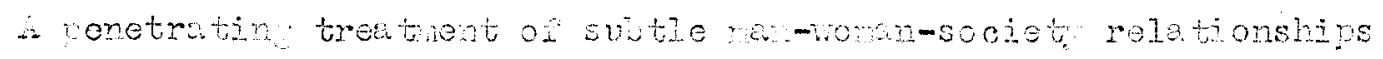
is charaterietic ol a ver lame muber of odem metarhsical coens,

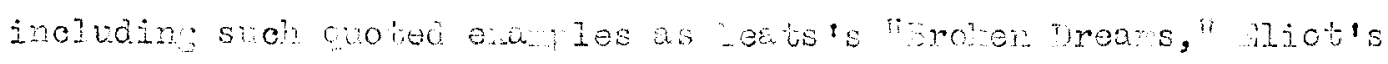

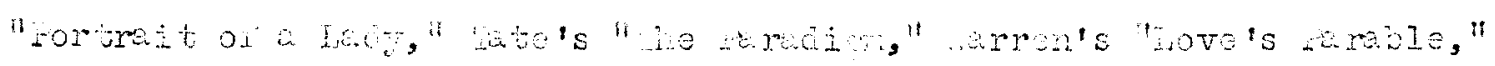




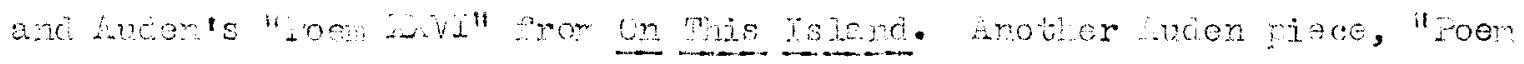

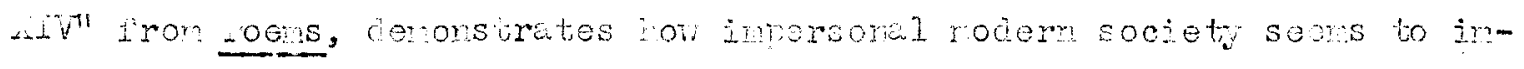
Wino wow and wen meanin ful ruman exnoriance. I cuote:

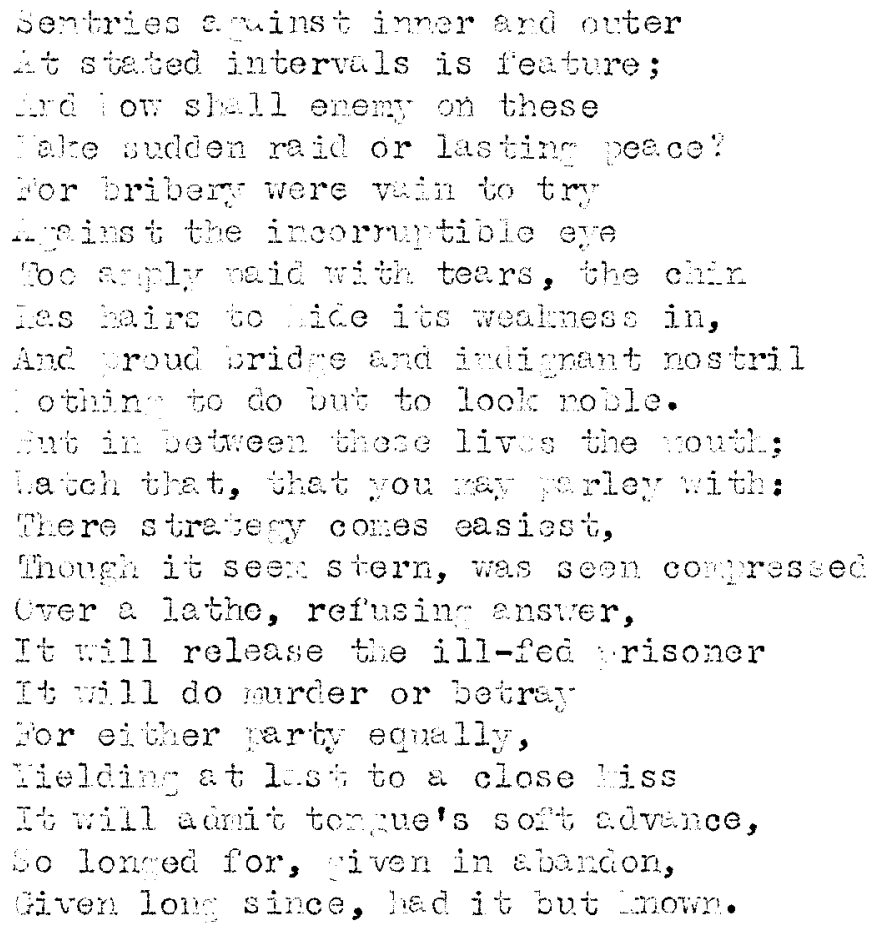

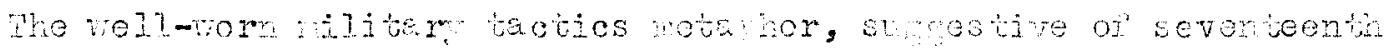

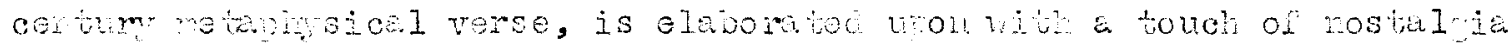

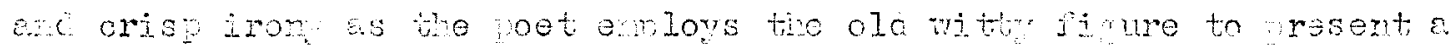

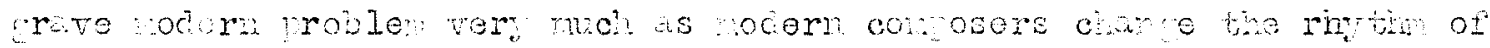

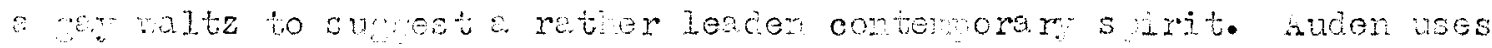
the device in a selp-inciusive attact on convertomal enorous betics in wh ich revels joth the seriousness and hur of the roblen of

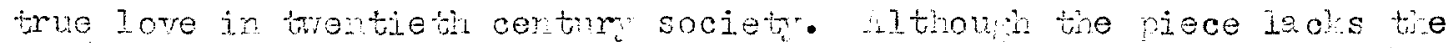

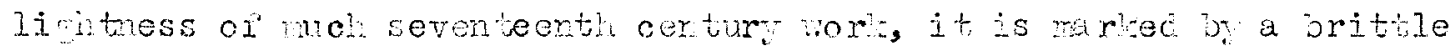

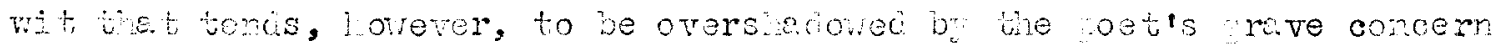

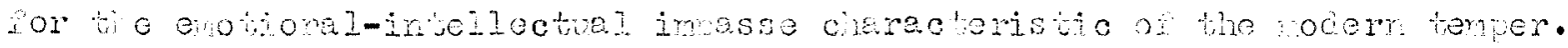

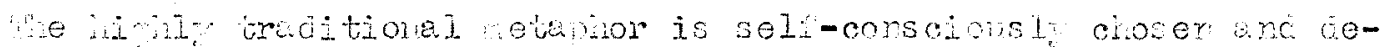

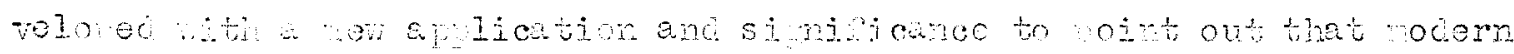

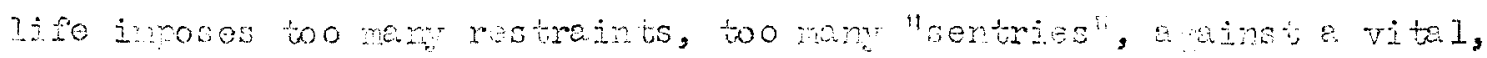


spontanous emoticnal tra social life. In the first severi ines of the row the torse, climpod idior suesets the odern scientific, jourrat istic morld that impinces on the sensitute. Bow the lon ing for simifi-

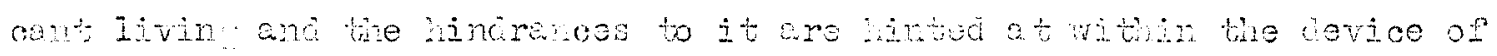

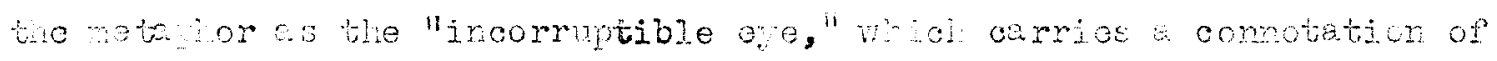

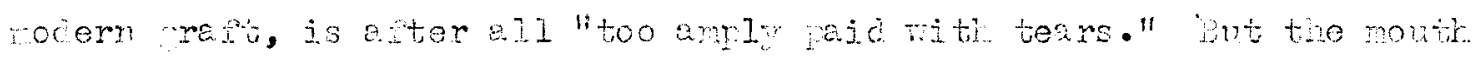
will relase the "til-ied risoner," probobly to be werstool as the

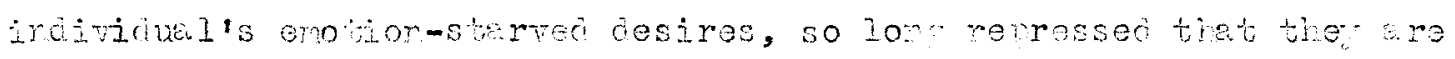

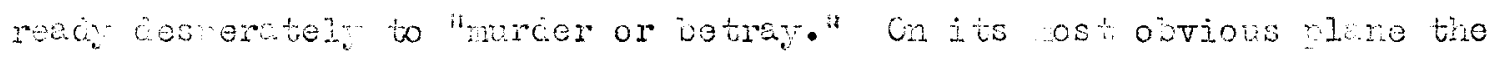

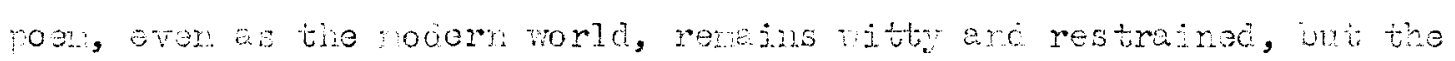
pot intimates thet boreath the hercered surfees of contomorem thought anc behavior there is a homor for is michot enotional experience. Wis

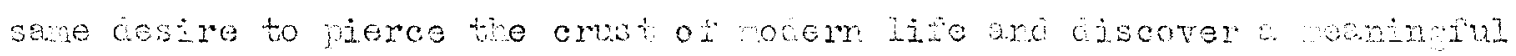

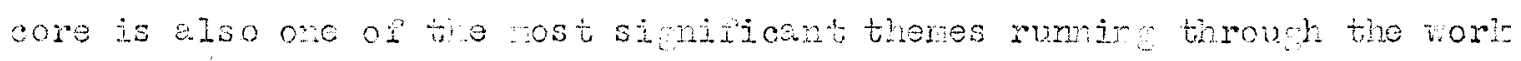
of siot, kenson, Tete, and arren.

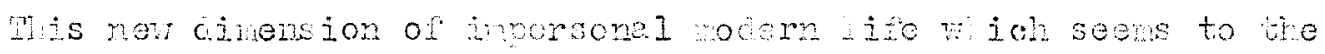
roet to bore in pron personel lite, as seen in rost of hiot's esply

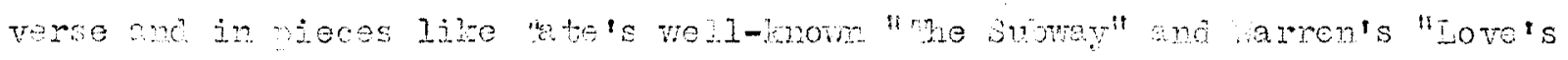
Emaie," is ictured vividir and samitively in the ovenin pesages

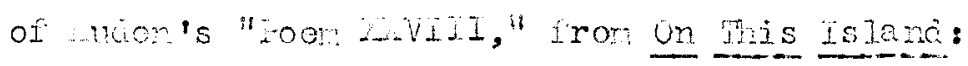

Tear, though the niltit is cone,

me crom still haunts tocey

Thet browht us to a room,

civernove, lofty as

$\therefore$ railvey tominus, and crowced in the loom

iere becis, and we in one

In a far coner lay.

cur wsters wore no clocks, e bissed and I wes lad

to overthiro you did, Indifterent to those who set with hostide eves 


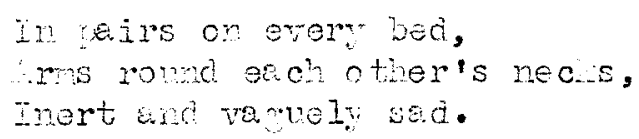

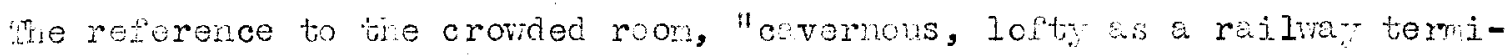

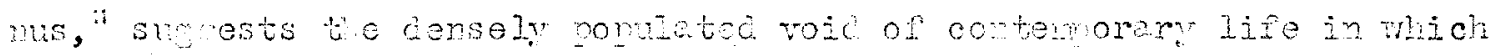
He individul becones lost, and the jotwe of the courles, "inert and venel sed" with "hostie eres, gives a similer irmession.

nIluce stovens, oet, cribic, and usinoss erecutive, is weIl gualitied to $\mathrm{s}$ eal of varions asects of the imect ow societ on modern

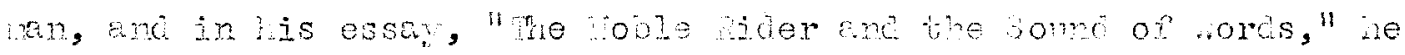
Liscusses "bie rosure of reality" in relution to a sonso of robility

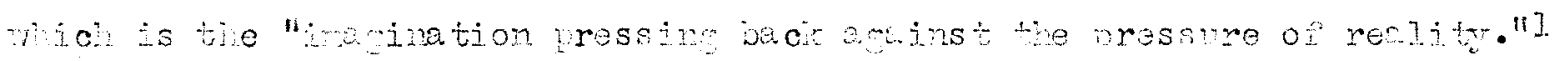

Qonjty is thines as tie are, the pnele we live in. irst there wes the co tortable victorian roaity of the do's and so's, then the sominoly nore ritel realit of the ecial and intellectuel wrombie the followec. Seerib beene violent ard so rokins. Iite iz vescalitr violentror

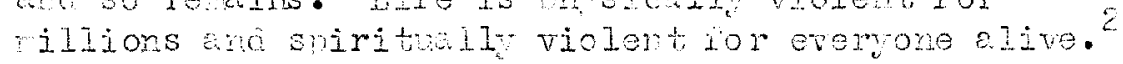

he oot-saective notes tati tose rolomt events are "inorasing wers is wentir wth increasing onen, in whit we conlec our preserce,"

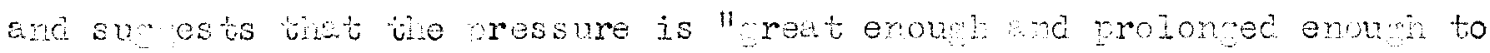

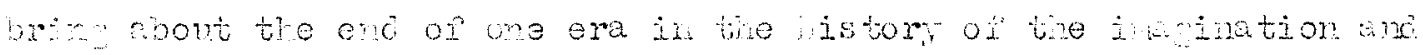
the betinnin" of another."

Tis sense of society irrin ine upon personal life is, twen, shared

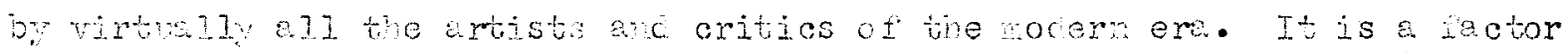
tiat, reurciess of similar treatents of mman emerience or the rise of

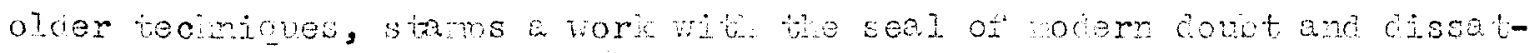
istagion

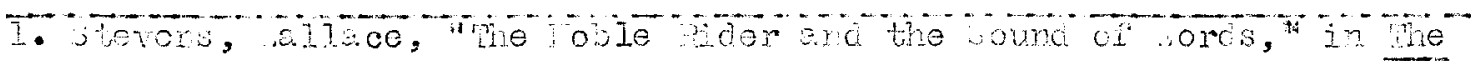
Landare ci netre, p. 120 2. $1030,0.12-15$

Doin., 111

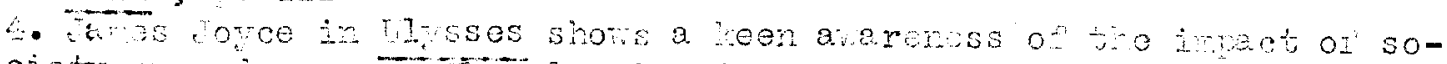

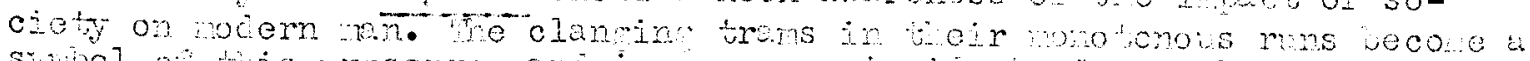

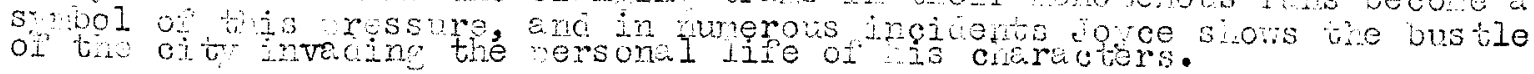




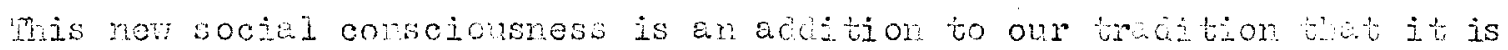

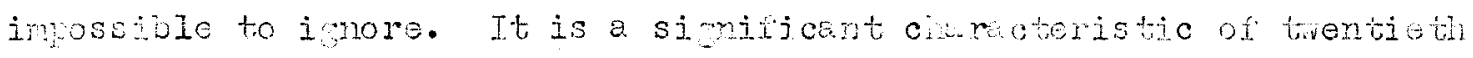

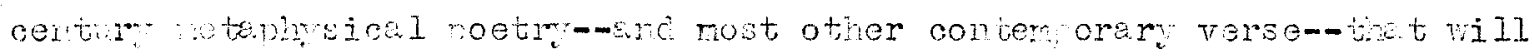

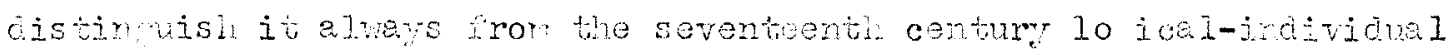
rexieto

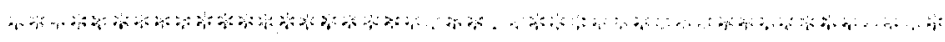

It is ossible to thint of tis nen sense ot the "prosure of reuliti" as havin sererel corollarios, such as the rorielm wase land

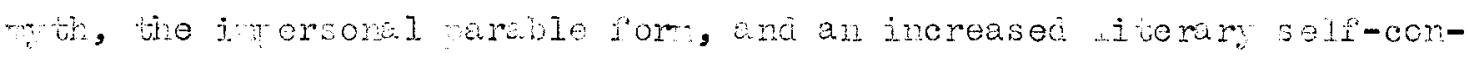
sciousuess end ublic-consciousress. Tese ere ald esvects of the artist's reater concem with societ, ane are roonir motions of his sonse

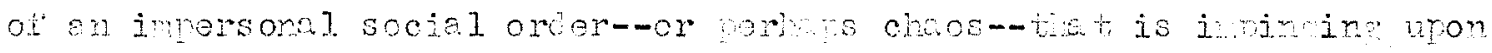
his rersone?, rivite life.

In this atscussion $t$ use the berm "rin" in a brokd sense to refer to any sycie of mowled or belief wich is shared in comon oy a rot

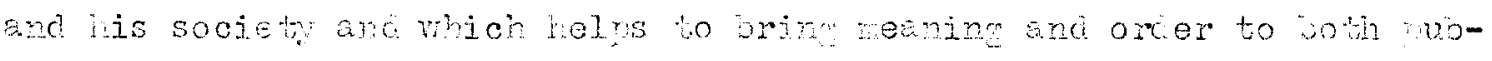
Iic axd rive ije The social aspect of woth is its nost imortent feature. Wh pot and the comon man nil bac won myth in ficeir considered thombt and their pasm pencies crd roly unon its sooial aspect in their atterts at emotionel or irtellectual commiction. In more primitive societies mo bounc men to obier in their conon womer

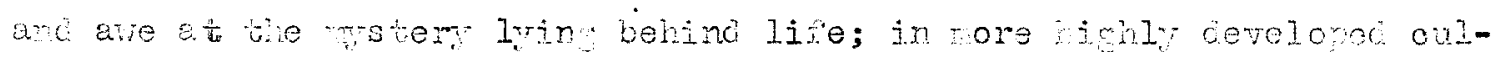

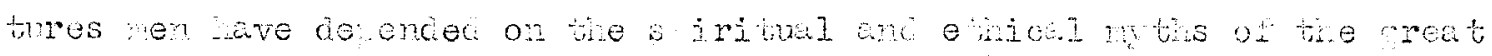

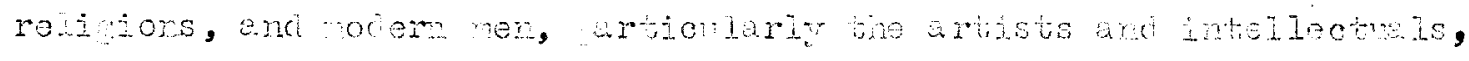
have sount soctal ard suclolo ical adjutrent, consolaton, end con-

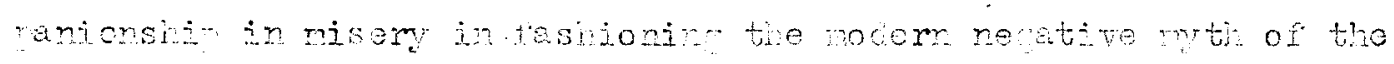




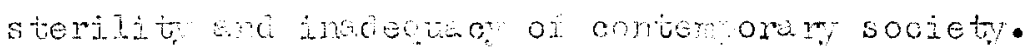

wch mical raterial in the savnteenth contury wa either slowly

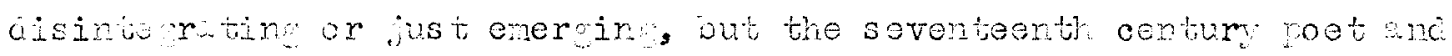
his socjet donencied in cormon, and otten as a matuer ol course, on seversi treditions and stems, includin the old soholasuic beliers and

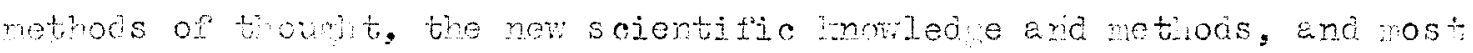

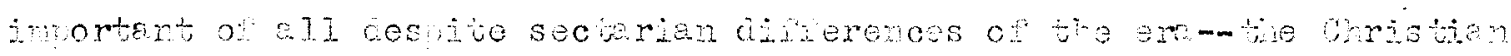

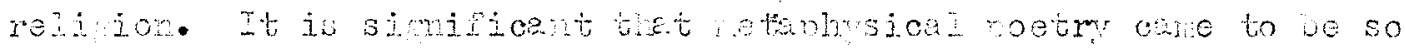
cailed becuse o. its learrin.

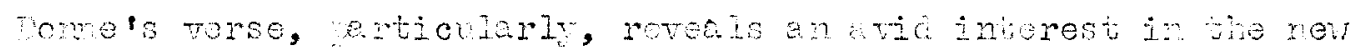
science. In arne rimrose" and in "revive love, for instance, the

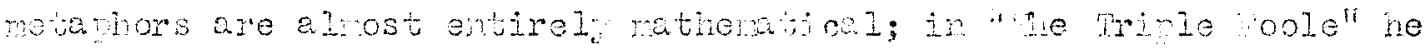
becomes reojonical in rotarrin to the whichtor of weter in its

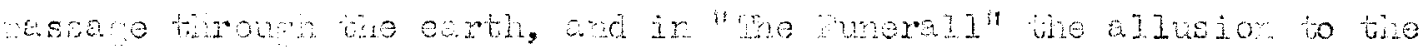

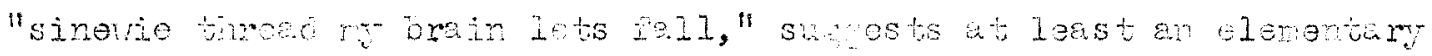
mowlede of tie remous sutem. 4 jor and ilal interest in now poMranic aiscoveries was manifestoc' by doth onne and arvell. Dore's favorite notaphor wes the "ilet ap," enroyed in such contresting

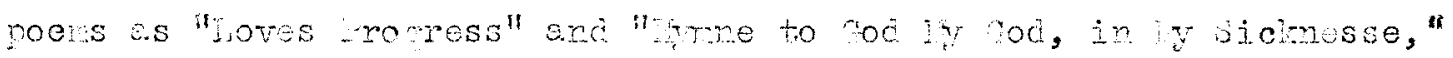
anc one of is ost femous metayors is the compas nime in its Valediction: Forbidang ournin." thet the pot saw promise and tool

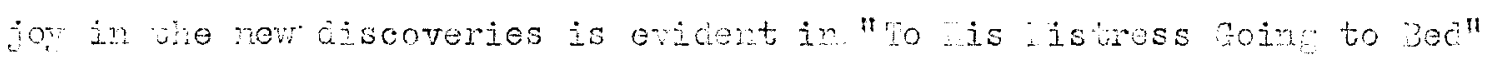

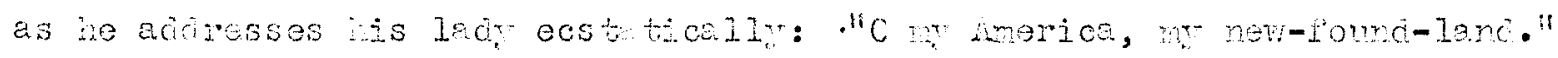

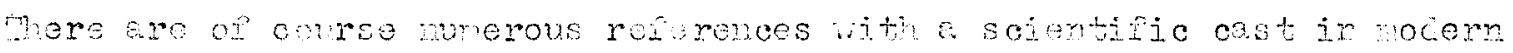

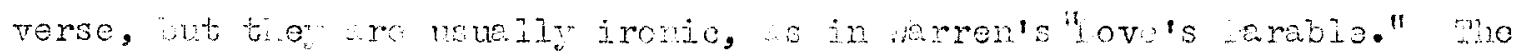
new science aru its eftorts, owever, for tie nost art ingurar bome

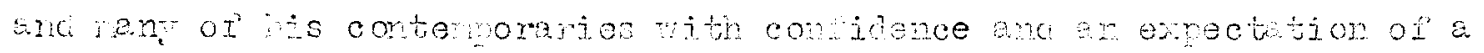

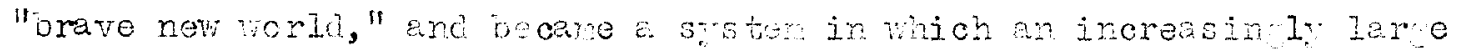


powion oí society conla place laithe

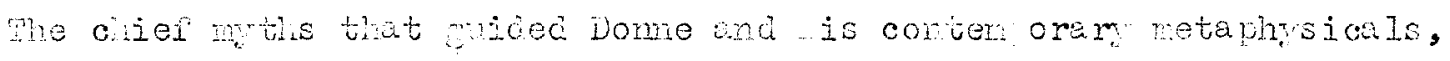
howevi, wo the twin, closely rolated sustos of scholastioism and Christiant. To ether these proviad monled e ebout the rature or the

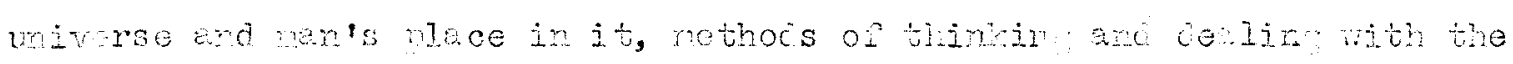

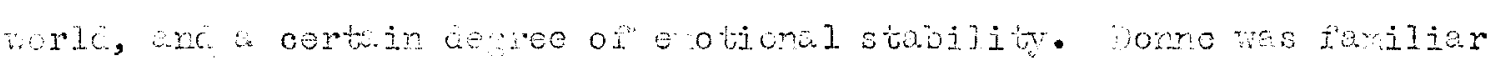

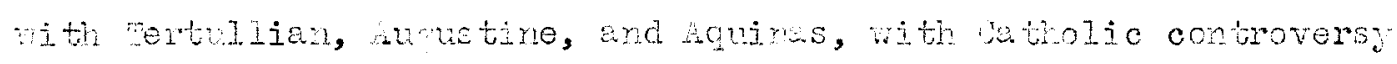
senerally, and of counse with the schoolmen's netuods of ruasonf and beir use of Ioric. The cependence of the soventeont contur etum sicals on $t$ is rast cisinto reting srotem is reflected in the lonical, s. llo istic prowien structure of pieces like Donne's "ihe Dissolution"

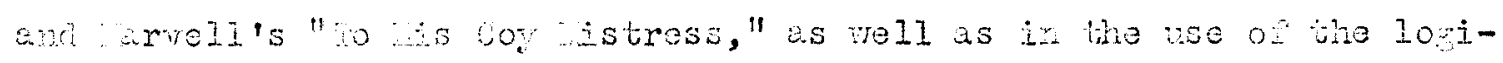

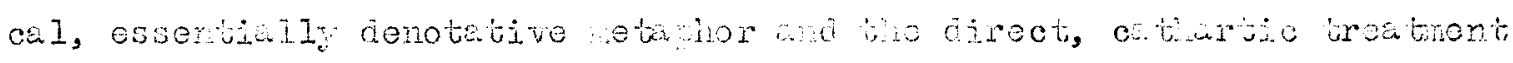

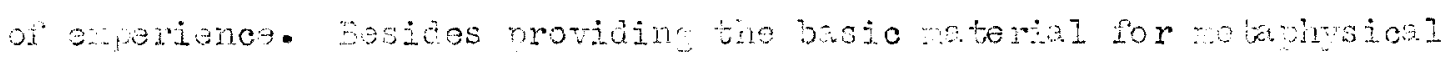

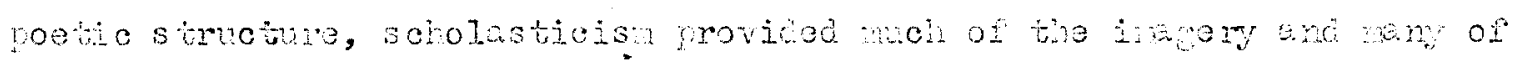

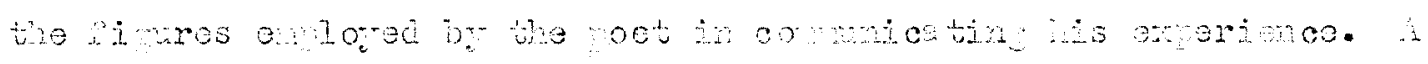

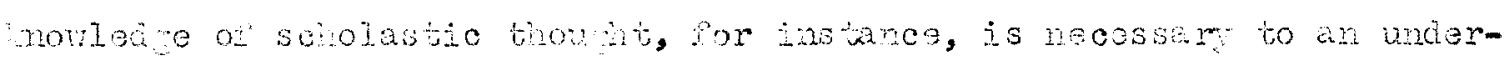

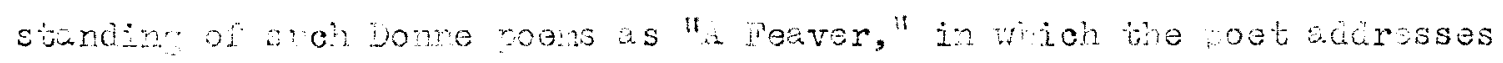

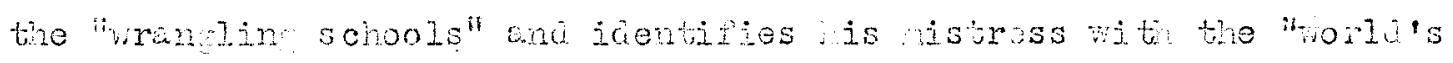

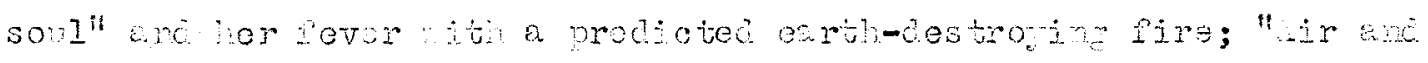
whols," compring an's anc women's iove with the purity of air and

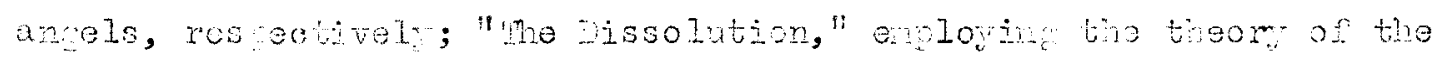

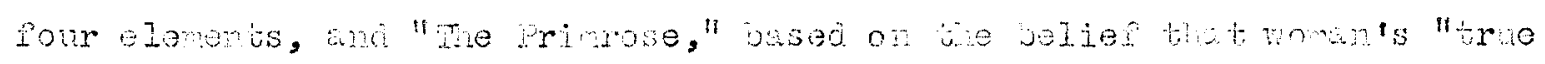
mover: is ive.

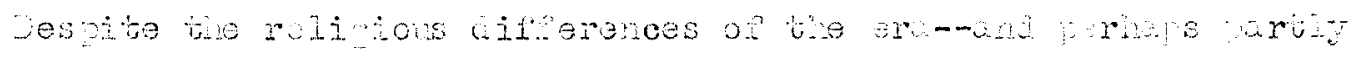

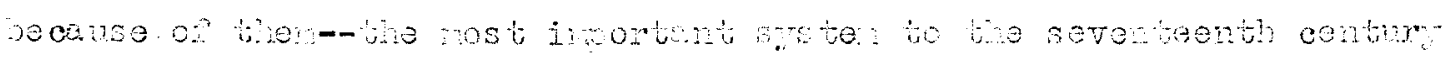

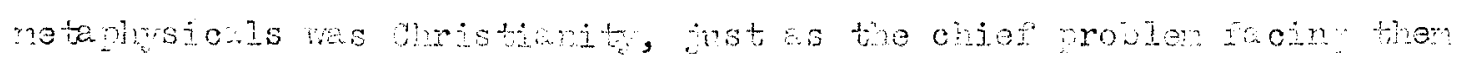




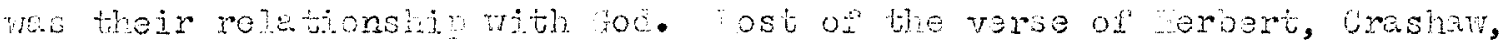

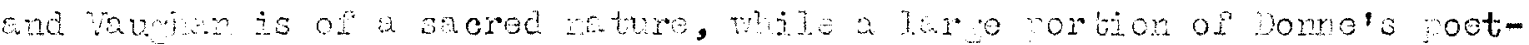

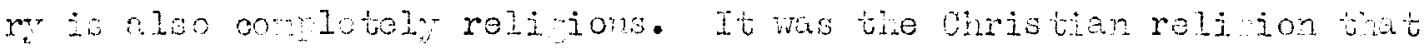

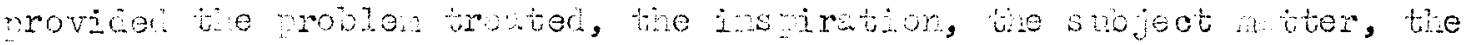
toxtural develorent, and nuce commicaton ossible. ws nes the case

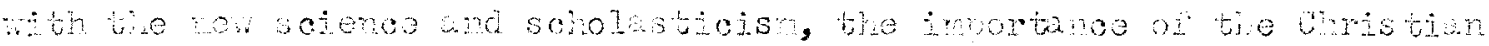

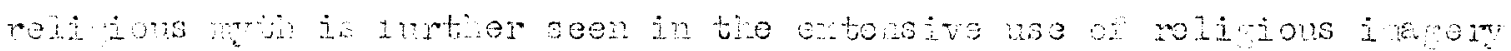

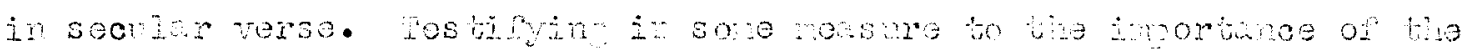

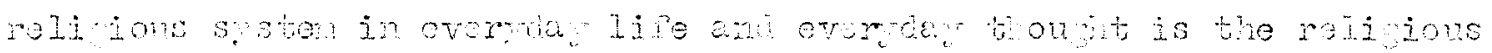

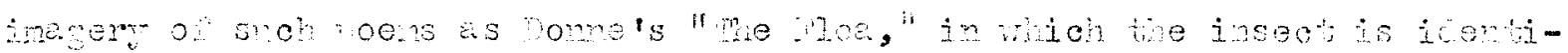

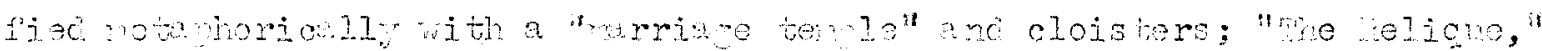

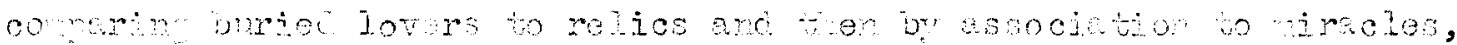

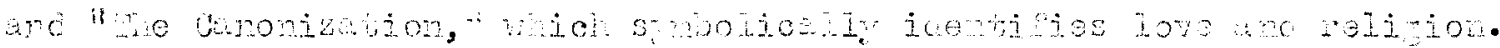

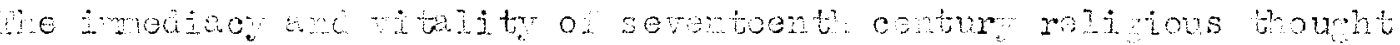

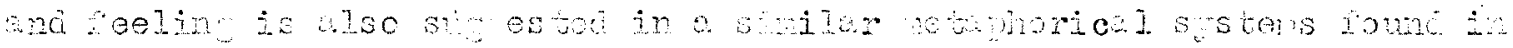

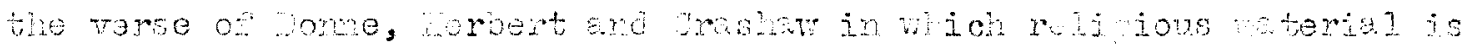

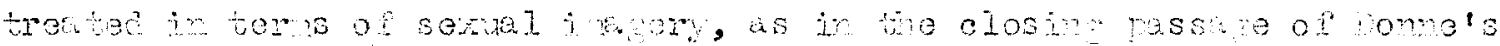

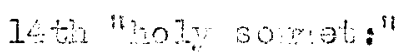

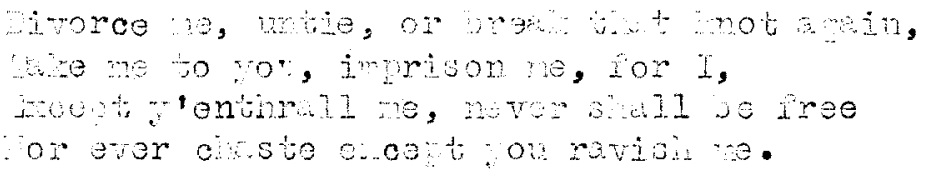

snd awan in tho Ioth somot:

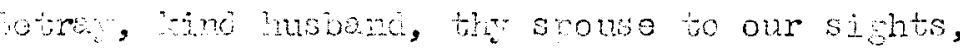

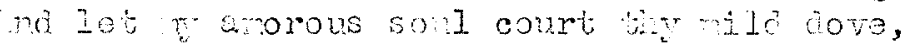

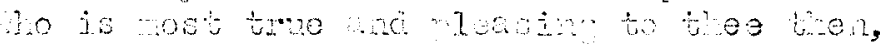

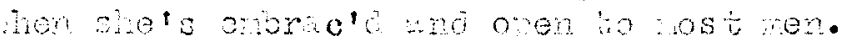

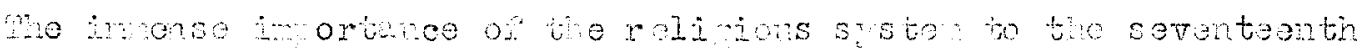

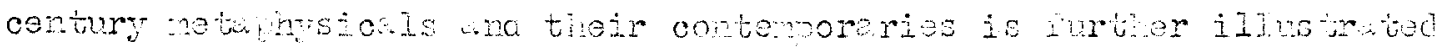

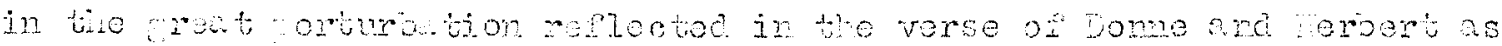

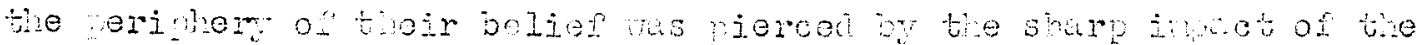




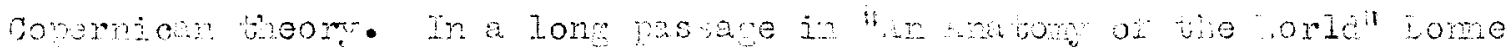
moums the gassing of the old "pro ortion, "he estaplisment on the "now nhilosophr" and orbent, in "helliotion," ories:

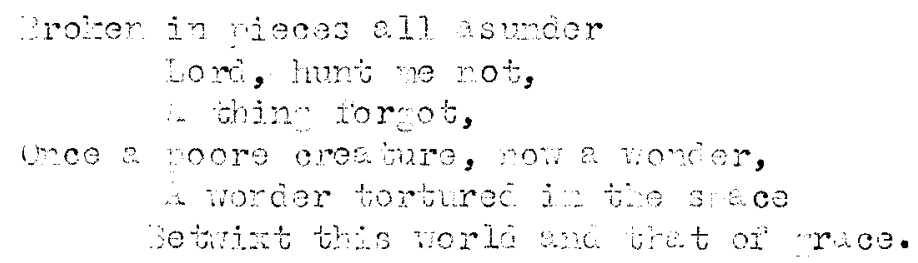

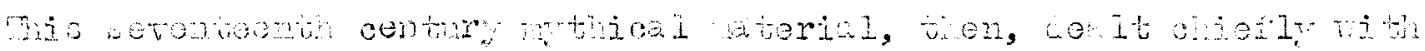

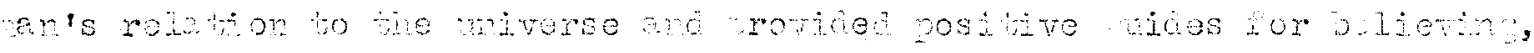

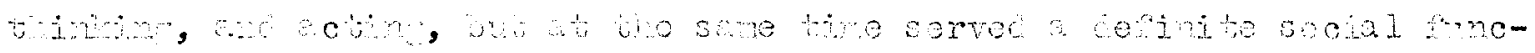

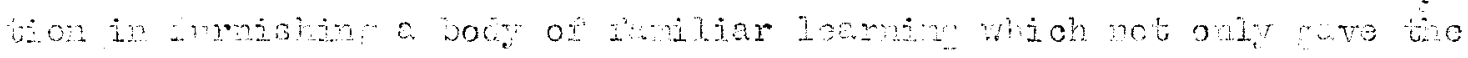

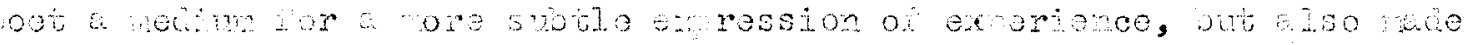

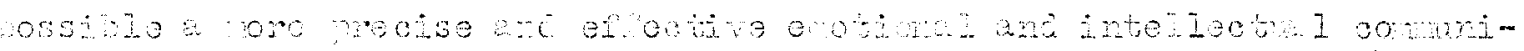

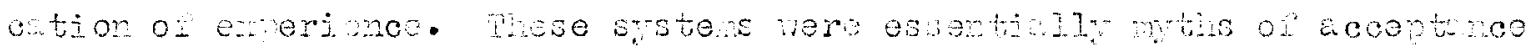

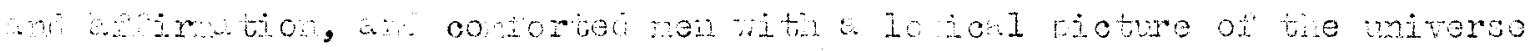

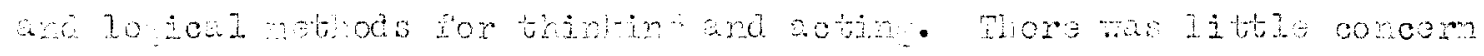

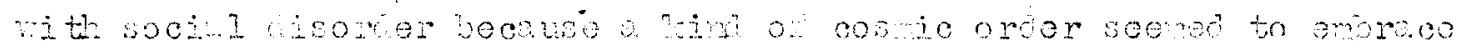

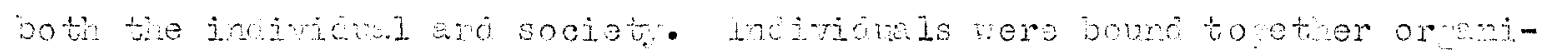

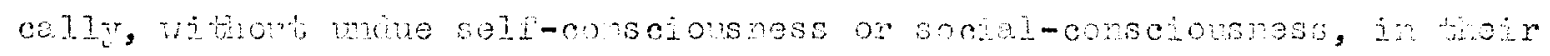

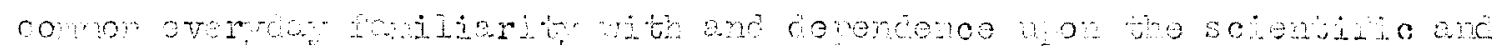
schots icoridons sustent

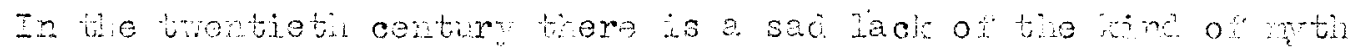

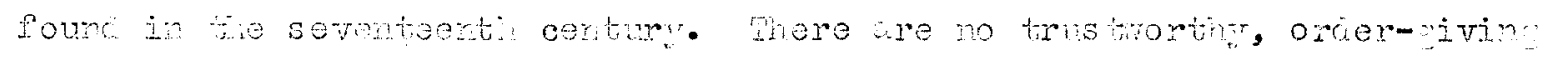

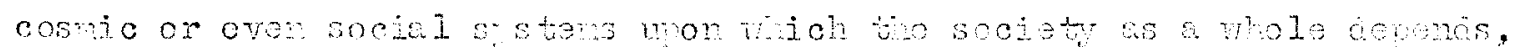

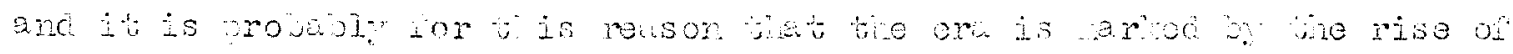

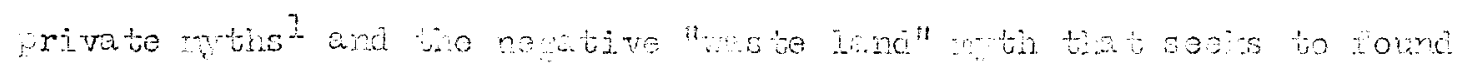

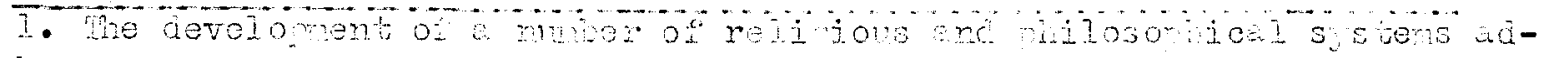

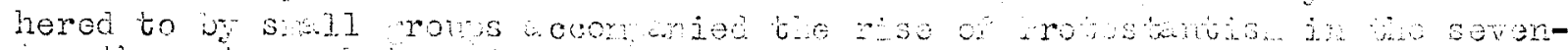

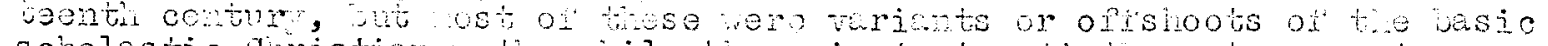

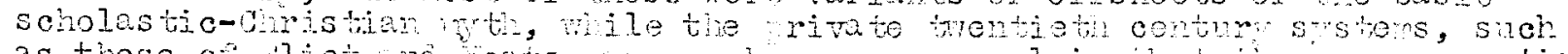
as those of tiot anc reats, arj no wore eroond in that bro are essential-

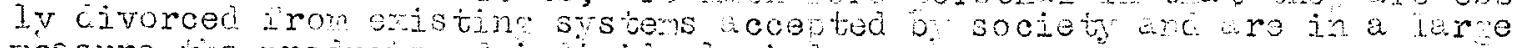
messure the procucos on ind viduel minos. 
symbolic order upon tie voiä, so to spenk, ano th bind nen, arbioularly

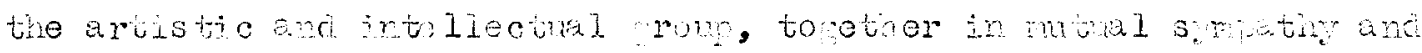

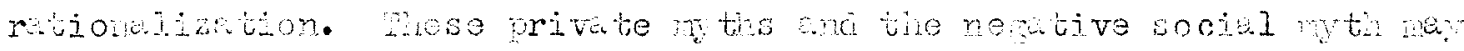

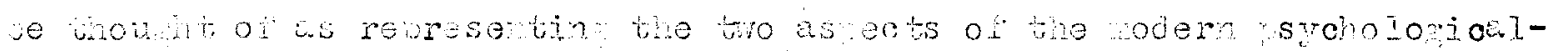
socjal rationalo.

-II pases of rocien literature are filzed with privte philosophical

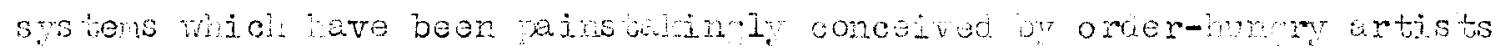

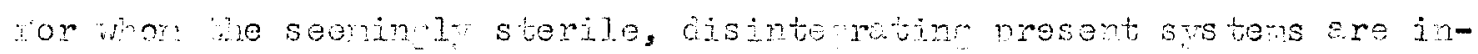

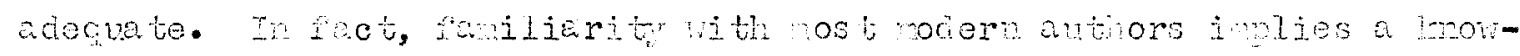
Jade of their rivito whis so that tie reacer ma undersand ellutons

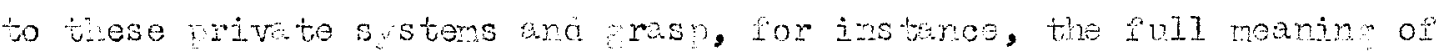
a pernems semin ly crence reterence to hacinths and roses (Atot) or

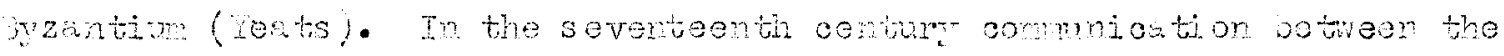

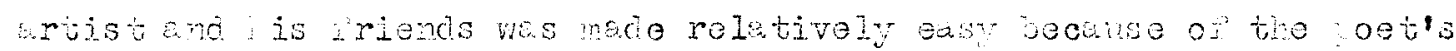
refence to a comion body of knowien e, wut in the twentieti century

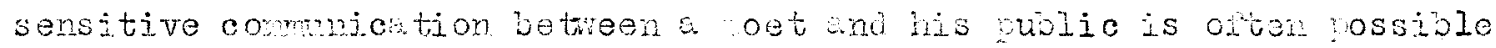

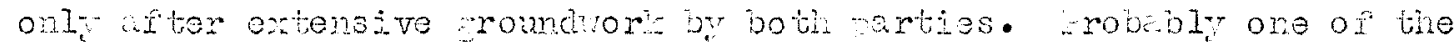

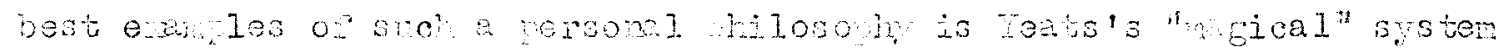

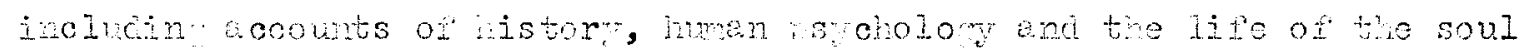
apter deati.

is histonicul s; sten, somomat similer to oswald genler's theom

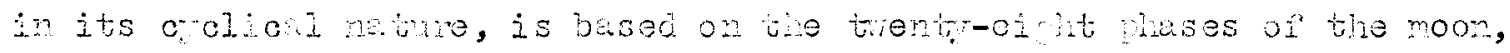

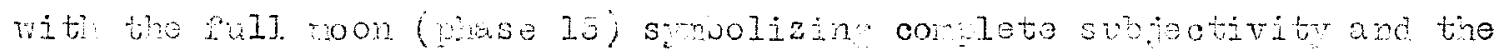

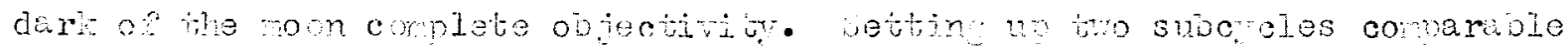
to the wan and min of the mon, he laces the oustinian byantine

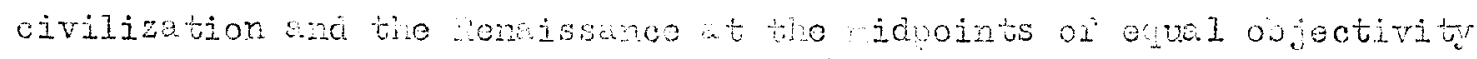

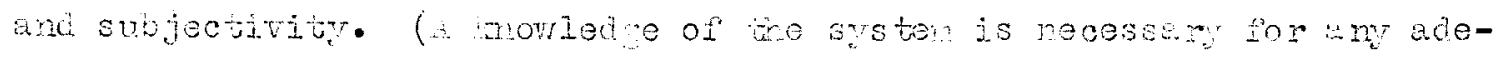

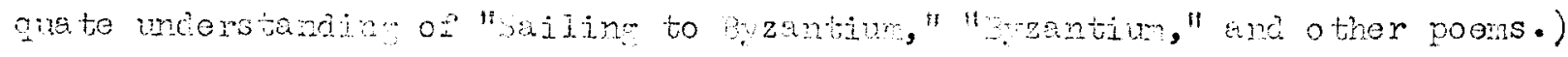




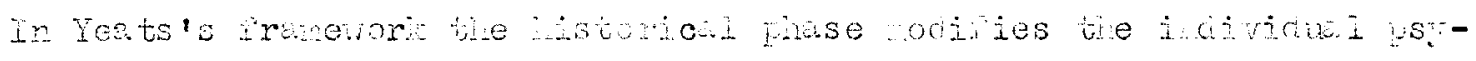
cholow, and in the pot's aychologicel ayser jan possesses ill, ask

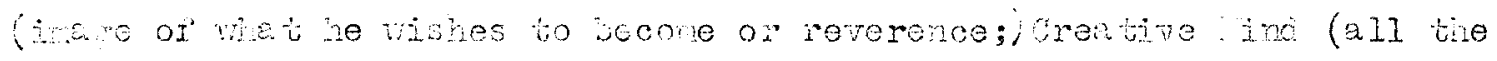

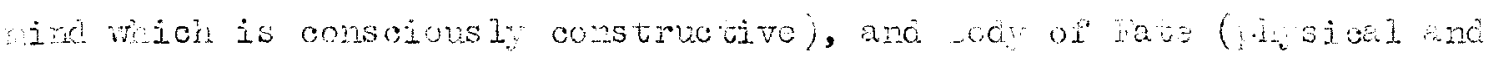

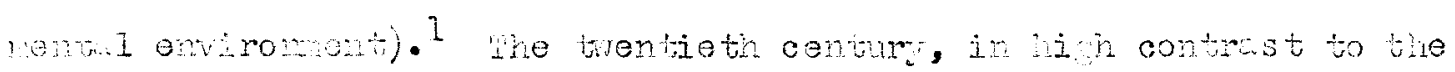

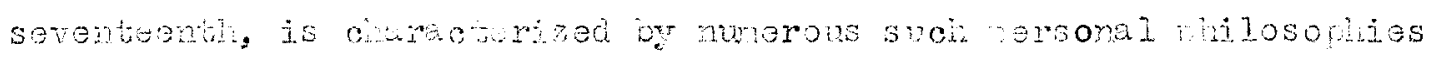

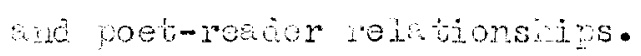

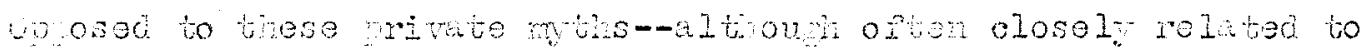

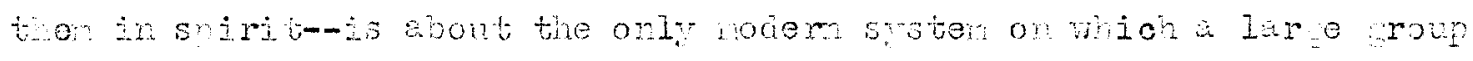

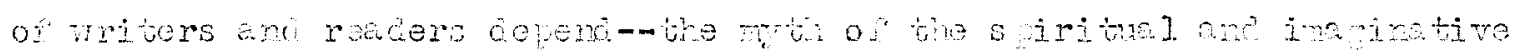

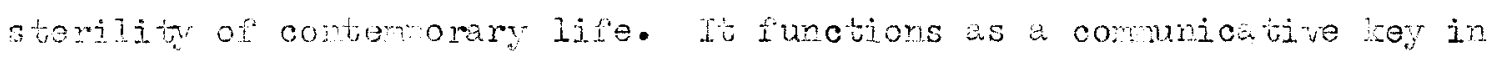

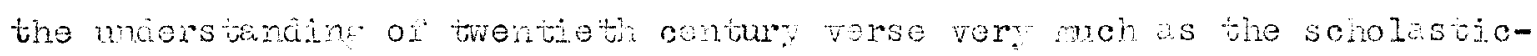

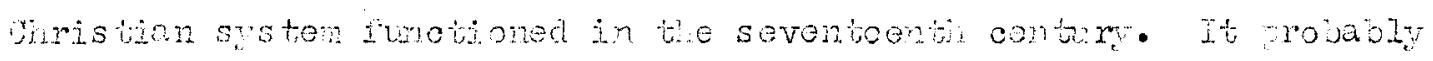

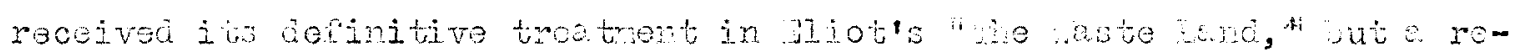

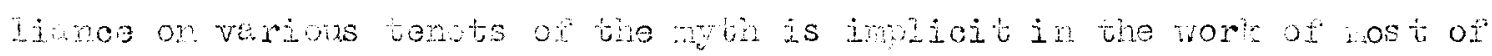

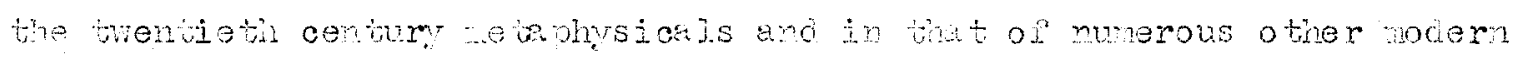
rricens.

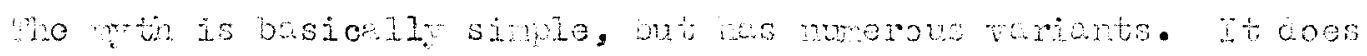

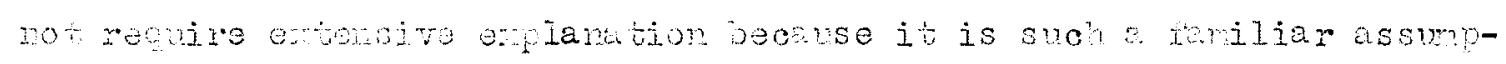
thon in roding. it holis thet the trentioth centur in its vitali

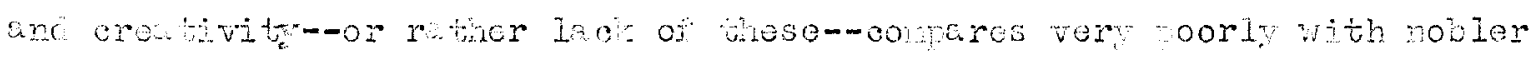

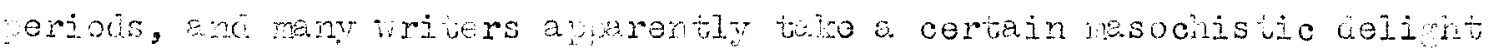

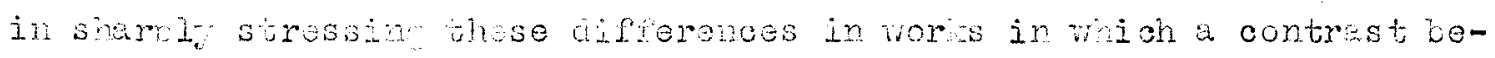

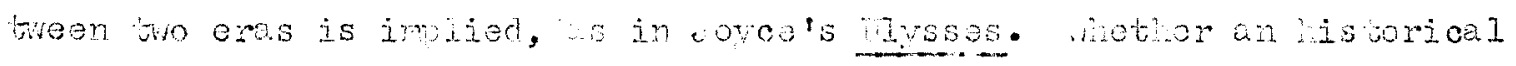

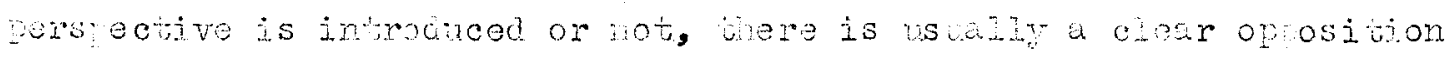

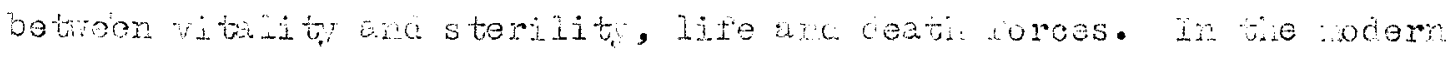
1. 300 , c10ant, or: ost., $177-135$ 
period, accortin to the myth, wan feels hinself insinilicant, wtovot

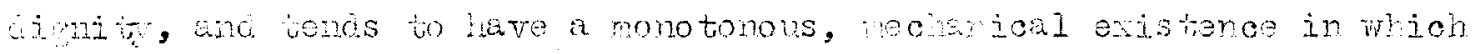

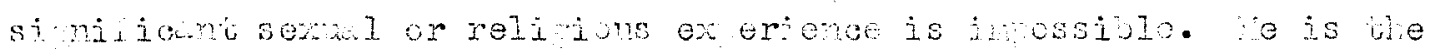

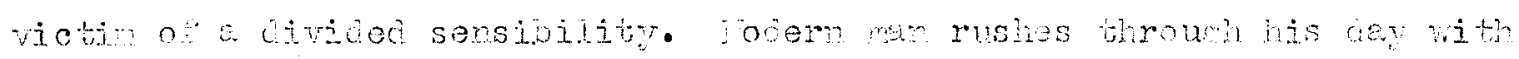

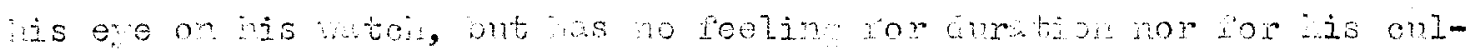

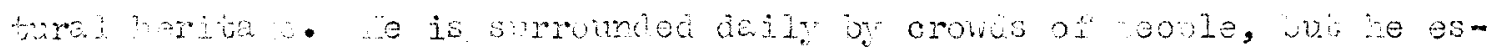

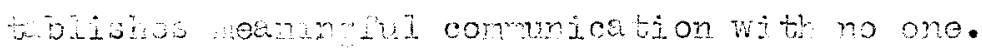

sut the shar Iy critical moet turns ont in sone neasure to jo a

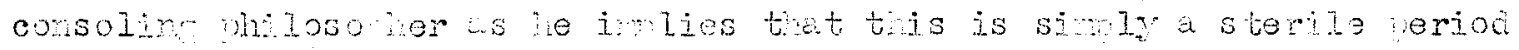

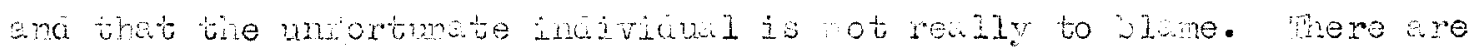
ony ration vame references to a concet of u modern, judustrial, scien-

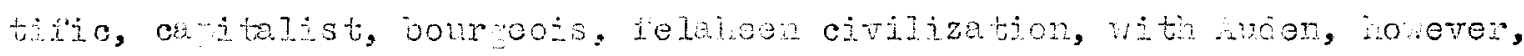

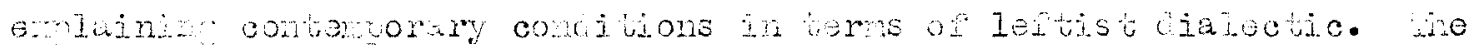

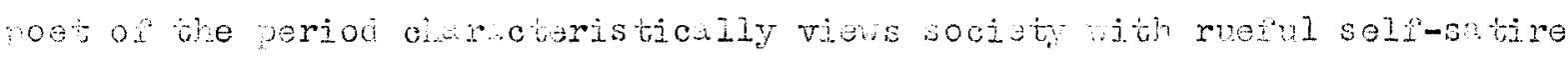

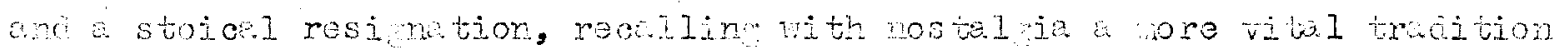

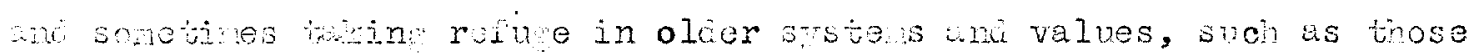

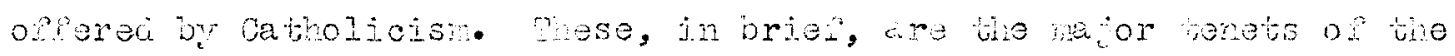

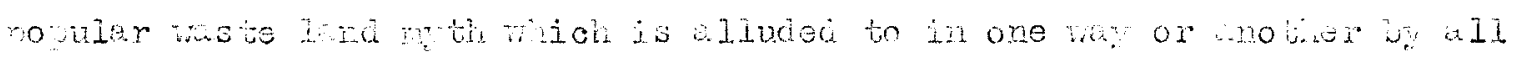

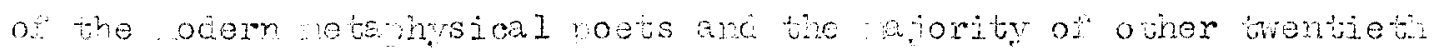

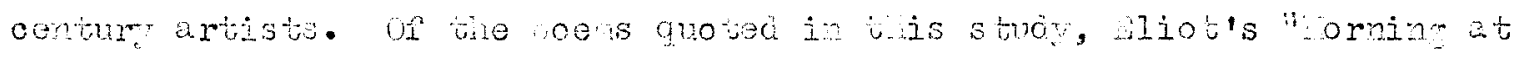

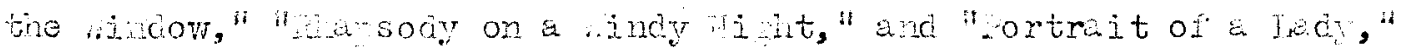

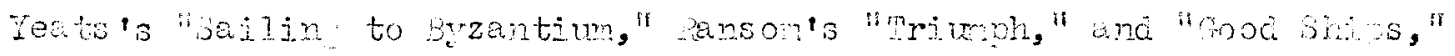

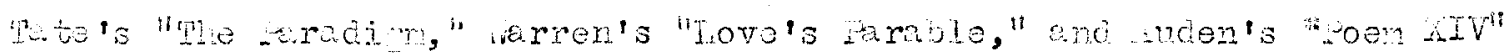

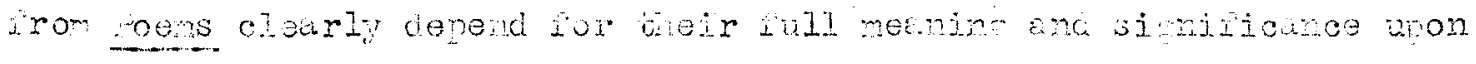
this odem maste Iand rothe

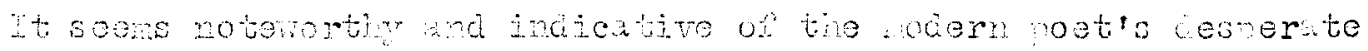

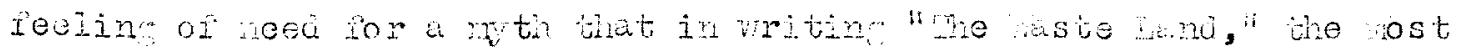




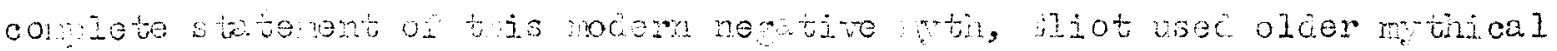
Wor mace mom to tis peneration throwh scholarsho, ruter than mom-

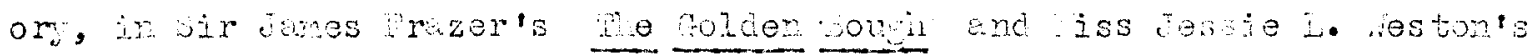

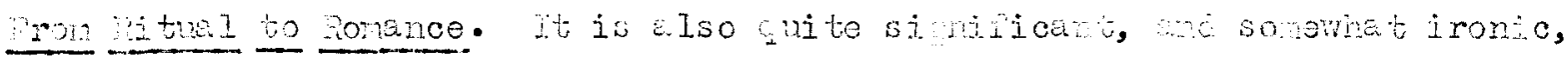

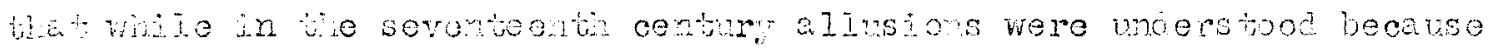

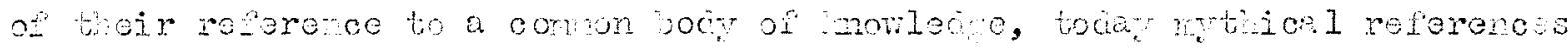

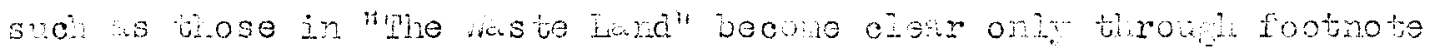
ext Iarations.

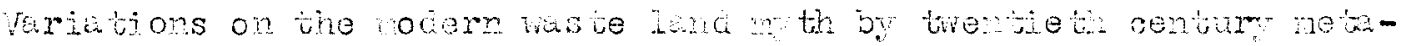

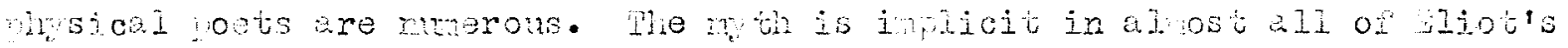

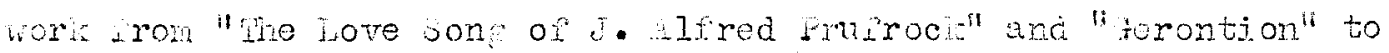

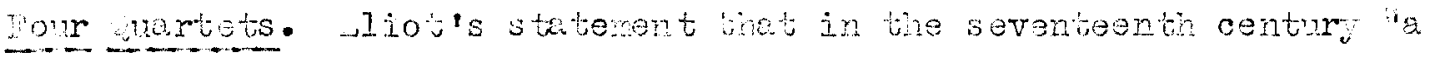

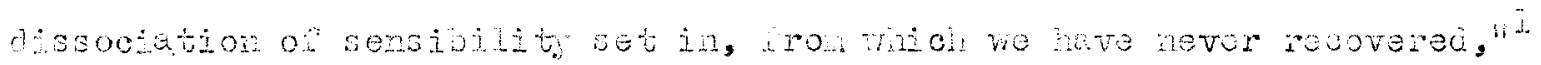

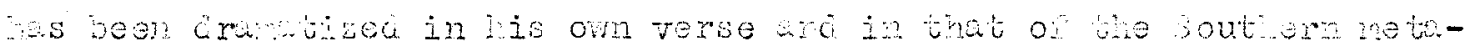

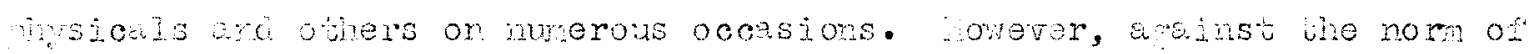

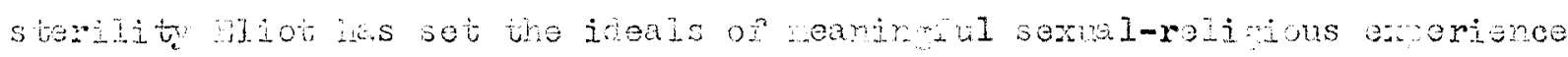

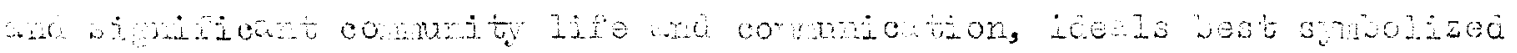

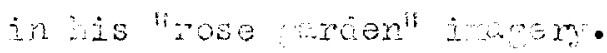

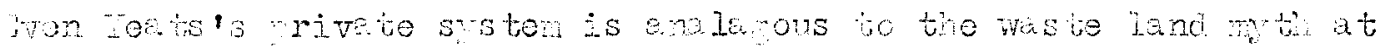

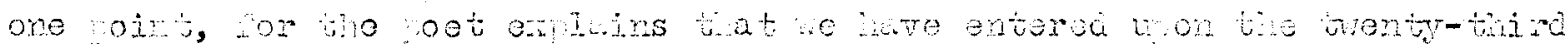
phase, an ere of warchic violende whout refurence to values and of tech-

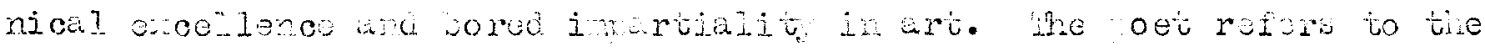

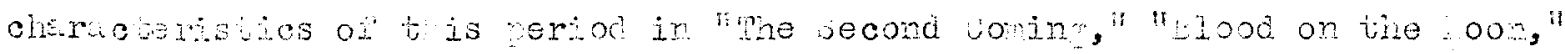

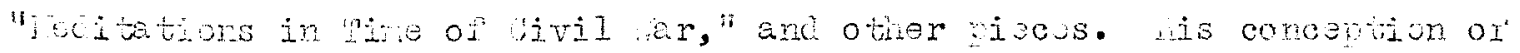

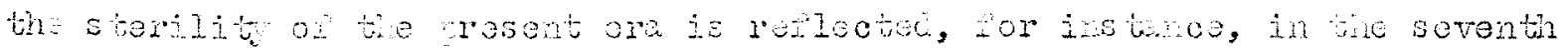

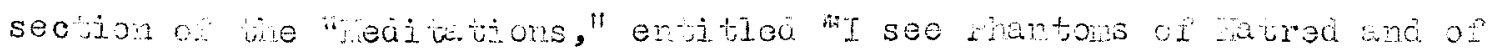




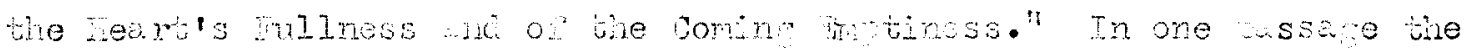

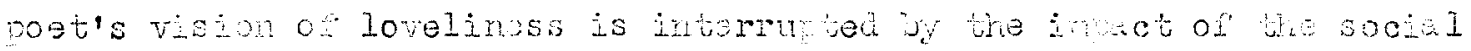
ditengor:

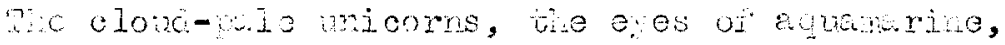

qhe quiverin jult-closed e ejiss, be ras ố cloud or of liso,

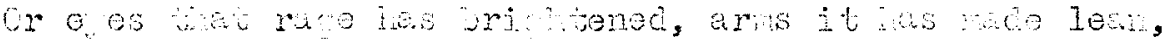

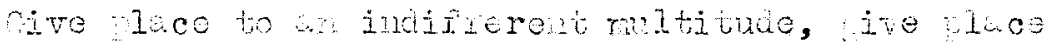

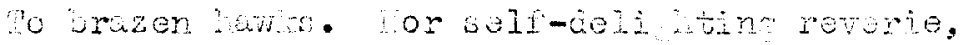

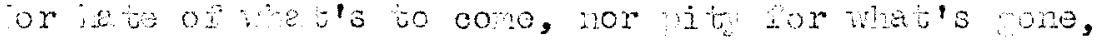

othin wo rit or claw, na the eye's comlacend,

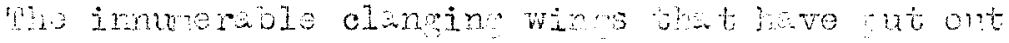
tie moon.

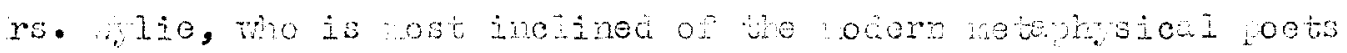

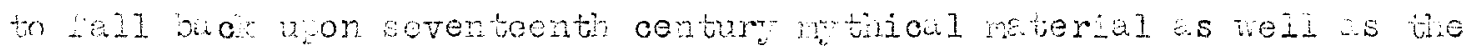

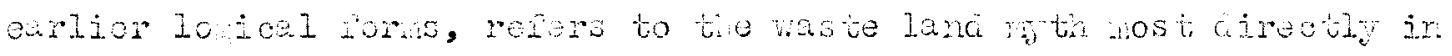

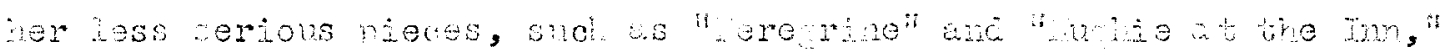

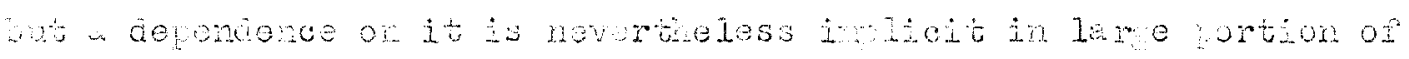
Ler terso.

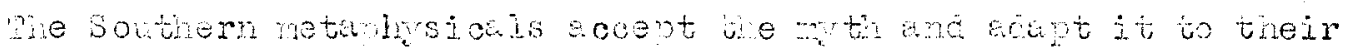

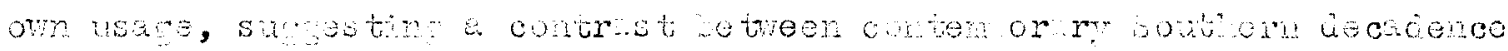

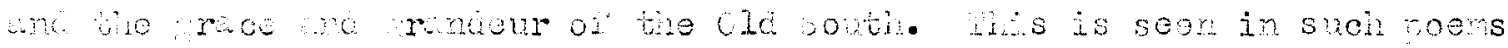

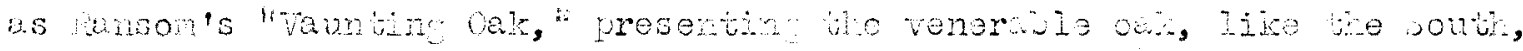

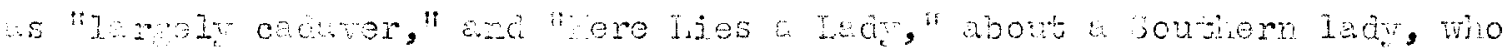

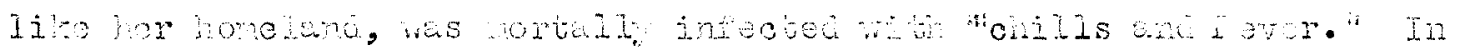

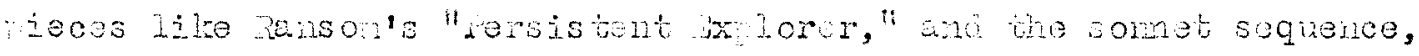

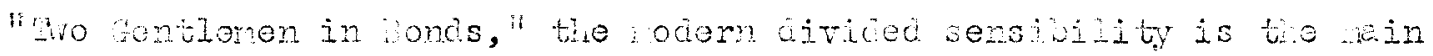

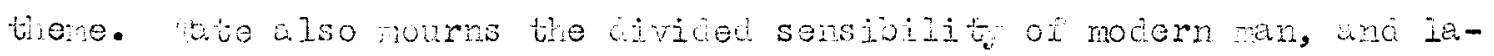

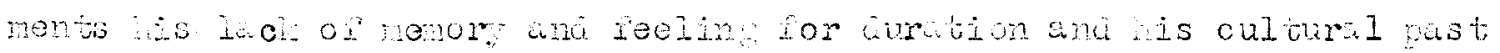

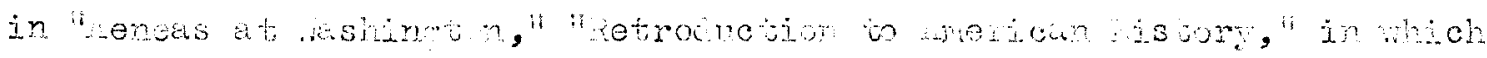

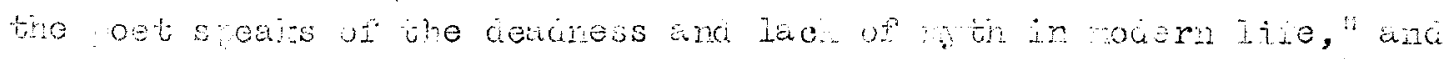

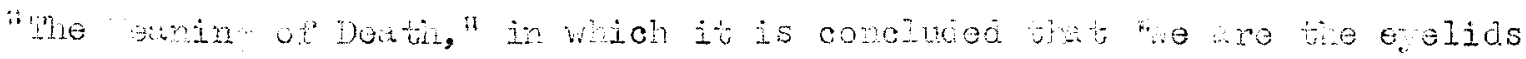

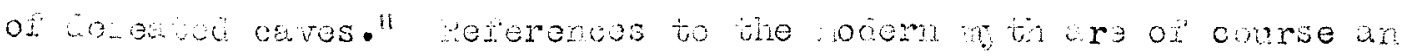


essential part of wren's "Love's farale," wile in is "ine Return: An filow," the intellactual-o otj ral ns cholonicul polarity is expressed wost noi gantly.

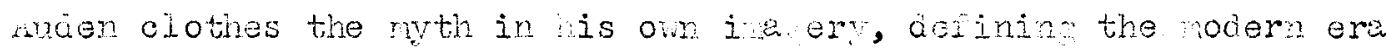

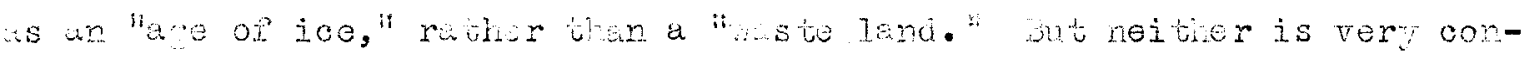
Goive to vital livin, and the neaning is the sane tuden, ioveren, piacus the principal biane for tis tuentieth century spiritul ico a o at the boor of the degabet leisure olass, and sees the prospect of nore

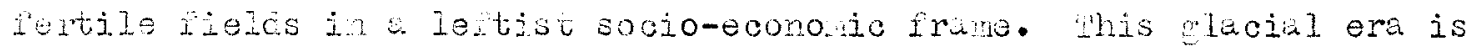
proclatme clearly in the closin stanza of idoen axi tron poems: Wile tis despaix with harciened eyevalis cries is folden Ape, is Silver...rater this,

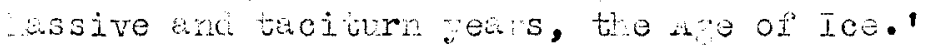

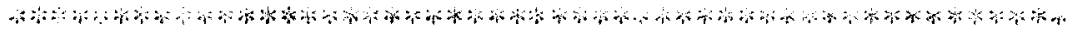

Hnotien re soreot of tis trentiet centur literar sooial-con-

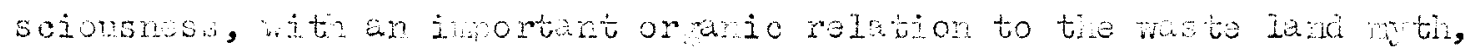

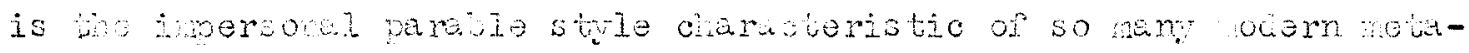

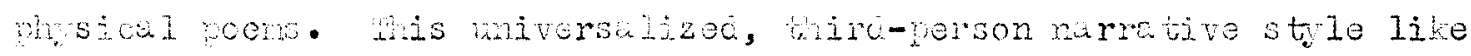

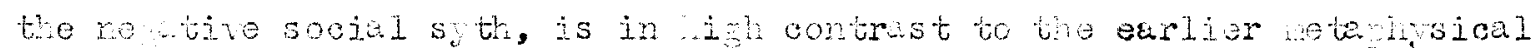

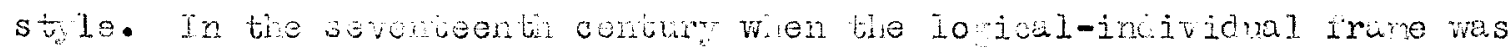
dominat, wer mothical material was hedr in comon wh tho oot chara-

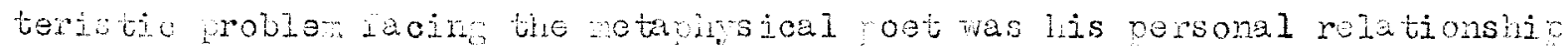
with on, the pot wrote rankly of is rive to life in tive pirst corson

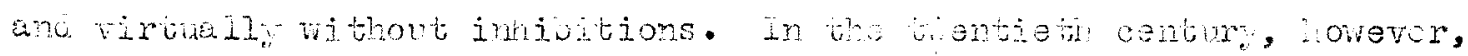

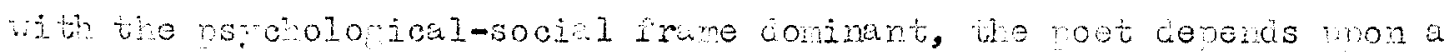
Wti that stresses neither cos ic nowlene nor gersonel relationships

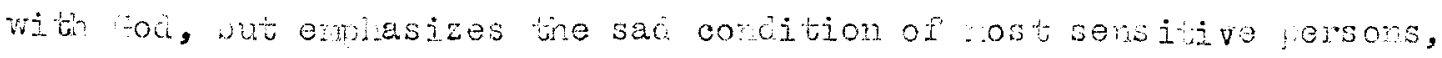
usually wh stit sensibilibios, in an inilited, uninarinative waste 


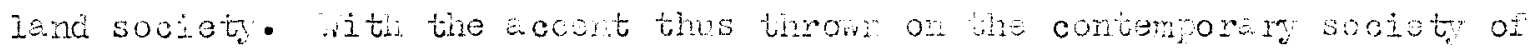

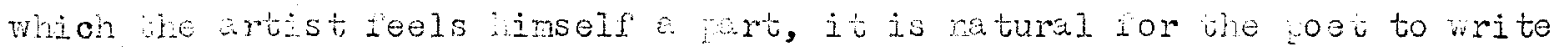

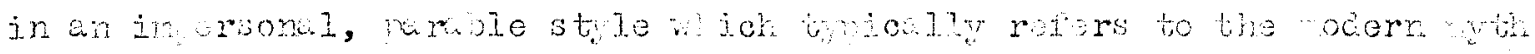

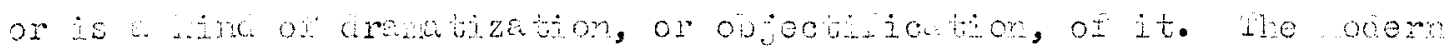

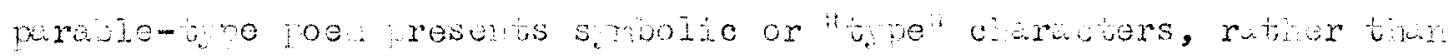

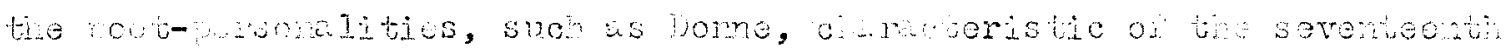

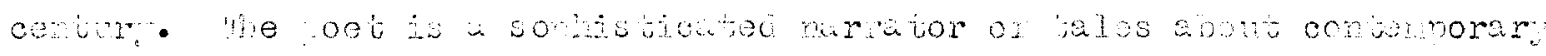

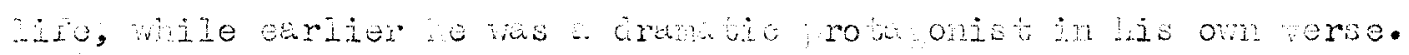

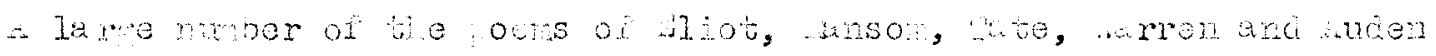

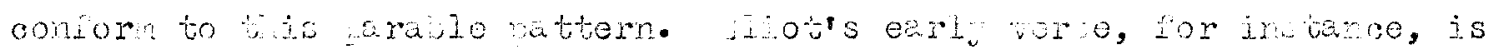

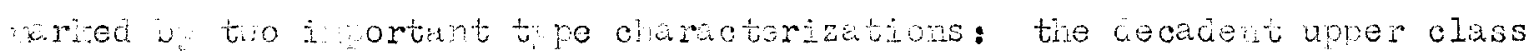

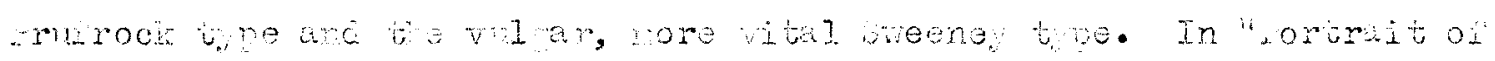

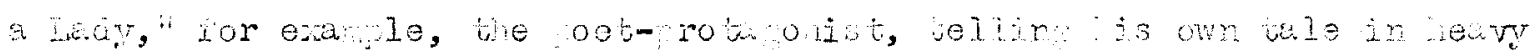

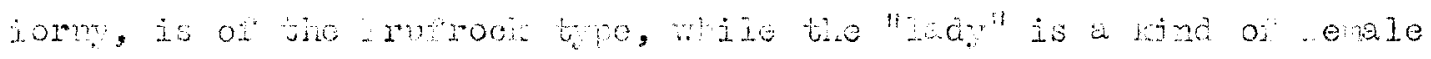
combormat of tho sale tope. The oetiresents the sterile, wovli-io

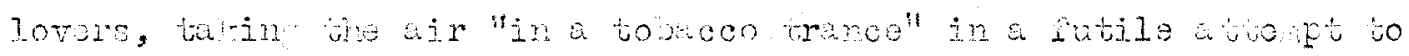

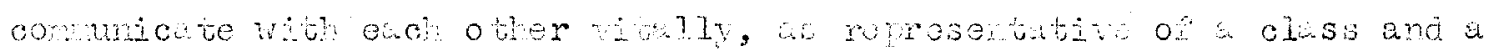

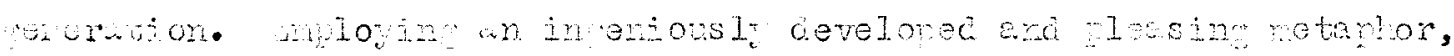

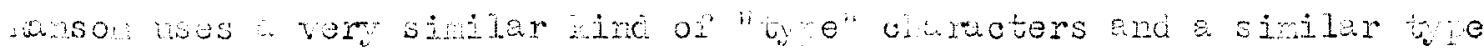

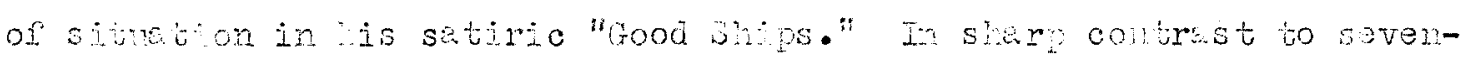
toont century rotaphoical verse wich daractoriatically emphasizea a statant of Lidividul, chienly personal, exerionce, such paraje-

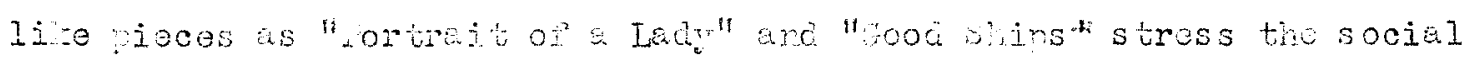

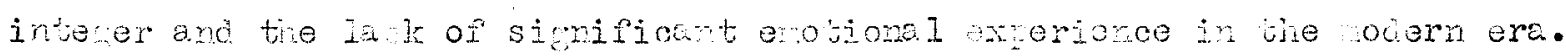

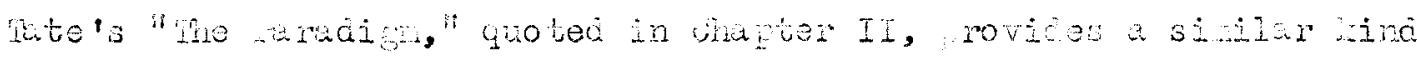

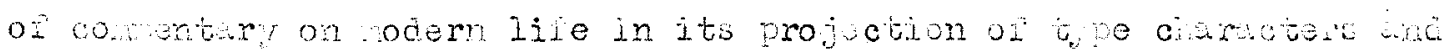
situbiuss. Lie oet weis is that tie mociern lovers, who have lost meanin iul commication with oech other, are seeled by the "tonsile aif" 
in their "joy is nd" (sugestive of tuden's waste land imaery.) The sophistickted eneralizin and moralizin in the two conoluding stanas rouncs ont the metaphical lerable form:

For in the air $8: 12$ Iovers reet Ster they he her out their love; iove's but the echo of retreet callit $b$ the surbear stretiled above

Wheir zroter exte trom the earth

Aroi lost. Leh is the other's crine.

this is their equity in birth-

ato is its inorent raradien.

L somemet less orvious examie is hansor"s "brectrel lovers." Wowever, two contrestin metahorical clusters, indicatin that the lovers are torr

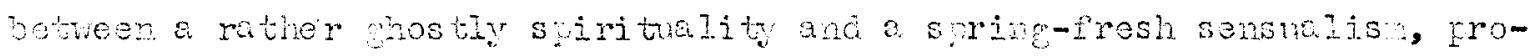
vides a coment on edolesence in meneral and verticularly modern adolescence in this era of iviced ensibilities. In onth piecos the author,

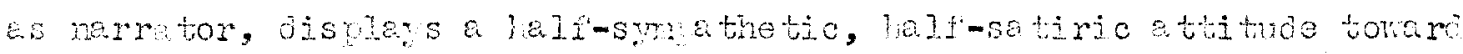

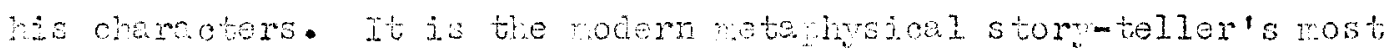

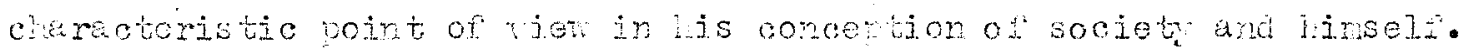

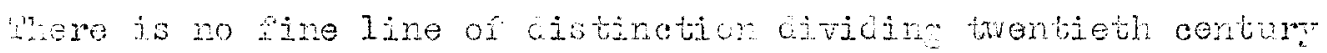

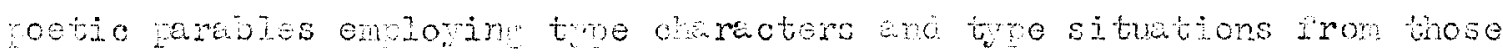

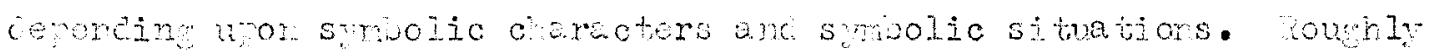
suoton, it int bo said thet oemo like arren's "Wove's arable and

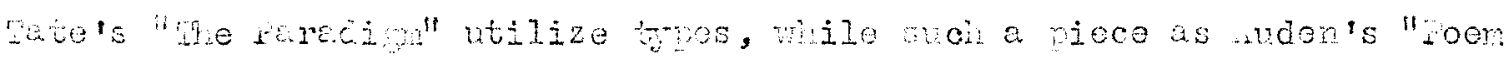
XIV, "atine a fresh use of the outworn miljtar metahor, is symbolic. the wholic wetanhsical rareble reaches its lullest anc clearest do-

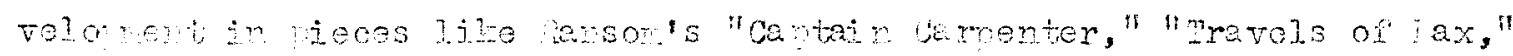

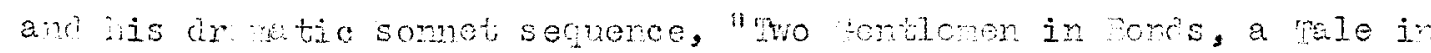

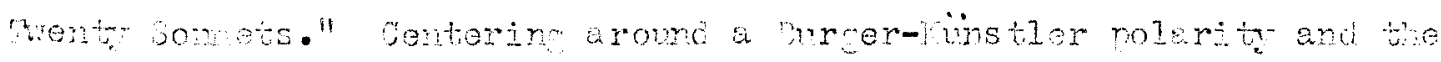

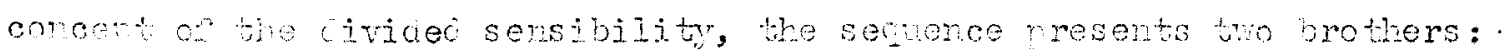

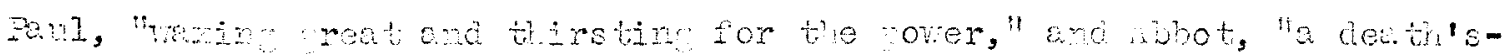
herd iun trom a tower." the issue is rointed in the last somet as 


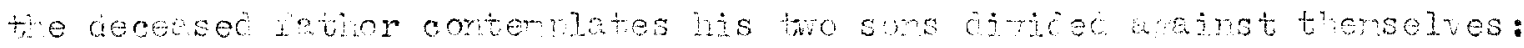

Hon I rember lite; ra ou of ne

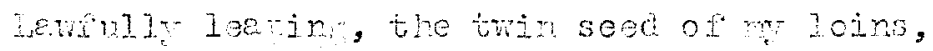

Brethron, whom no silt ratierhood disjoirs;

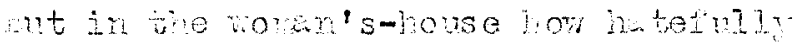

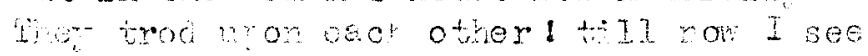

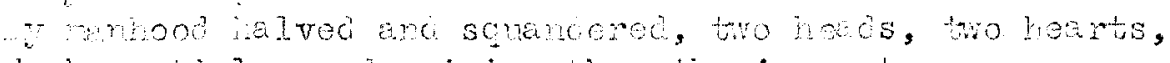

jol mojel son dostisin tho others rartos;

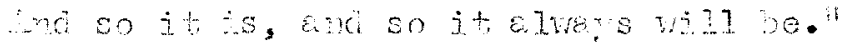

Wet mint it bo mecerion to reop

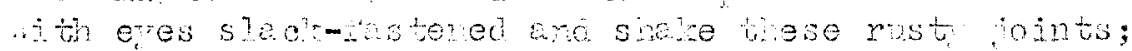

I ame specter, even if at some roints

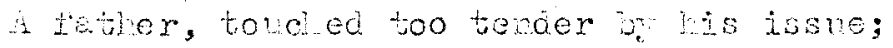

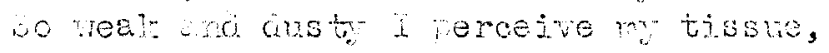

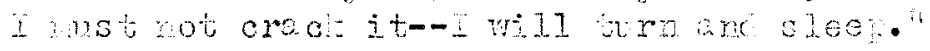

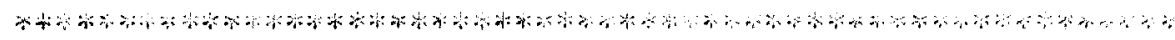

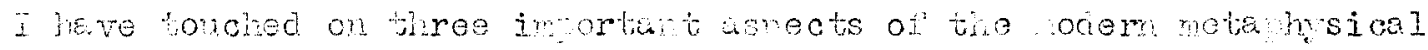
pot's reater wooiel concem: his feelin of e sociel imact uron persomal life, his devendence on the wete land my on privato s, sten, and

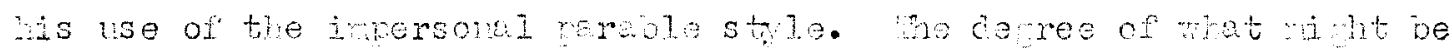

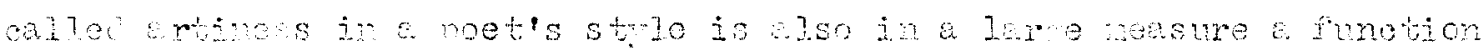

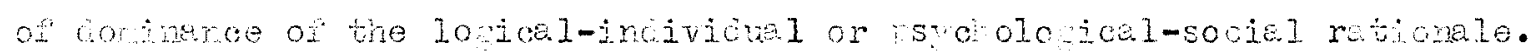
Bavortoestl ontur nota hysoal ootr, with its obsurity ard in-

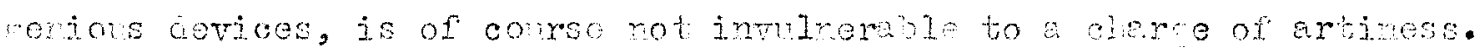

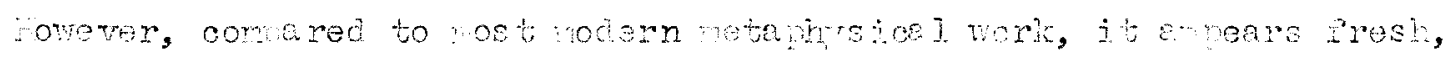

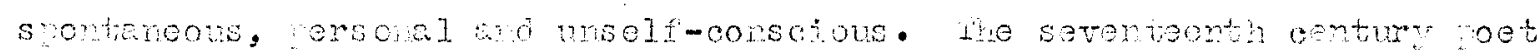

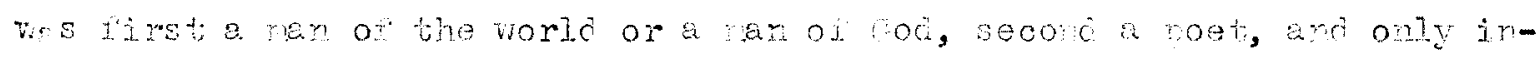

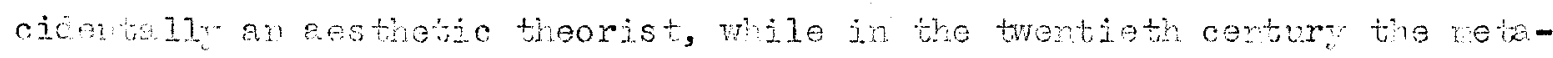

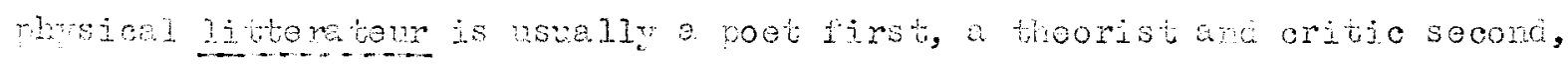

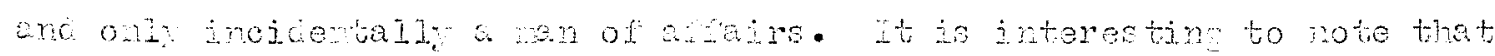

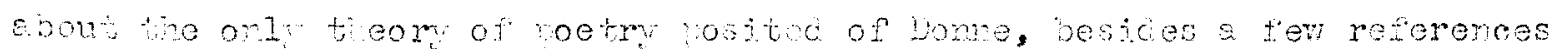

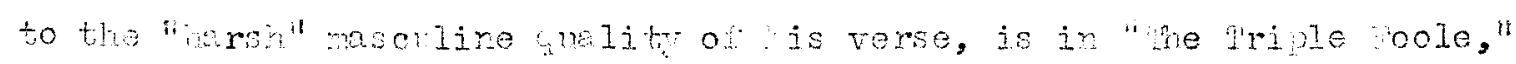
Winch deserrea to be guoted in its entirety: 
I an two fooles, I bnow.

wor tovine, and for sarine so

in Winte lootrr;

cut were's thet isean, that wald rot so

If she rould not den"?

Wher as theentis invare norrow crooked lanes

bo mine sec nctors srestull salt awe,

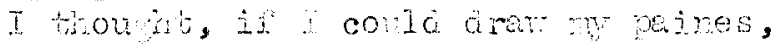

mour ares varation, I shoud bicm alla..

Crief brovit to mubera cenot se so sierce,

ror, he tanes it, liat lotwers it in verse.

Wht witen I here cone so,

wore nen, lis art and roj.ce to sitow,

Doth set and sine naino,

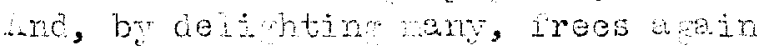

ridit, wicl rerse dic restraine.

To Love, and riede tribute of verse velows,

But not of such as leases when 'tis rege,

nothere increased by such son:

For woth their trimpins so are ulished,

and I, wjeh was two fooles, do so erow three:

Who are a little wise, the best fooles bee.

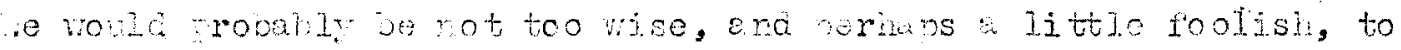

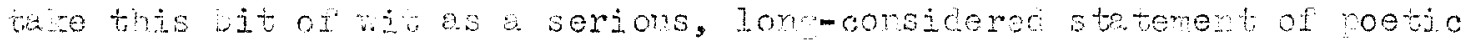

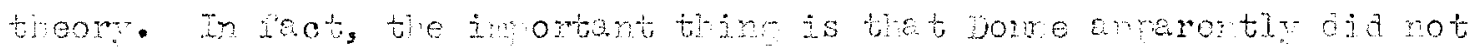
Les colled unon to wete serions otatoment of cesthetio theorv

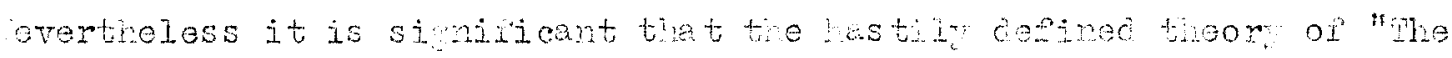
riple bole" is chareoteristio of the 20 ical-individul pint of view Wre cot thints of is verse es comothin ossentjelly rersonal and riWte, wo is interested in notry as a wedim for dealin. with life sit-

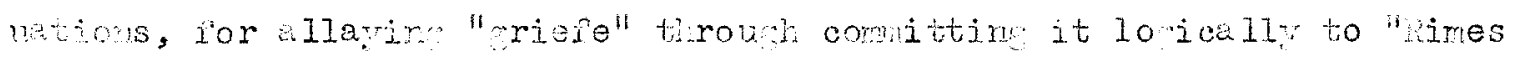
vexation." he shows fimself amare of the rrowem o commication, out is ciefh concemo whth the rolutionsh between the oet and his oetry In the twentieth century uncer the aejis of the wycholo icel-social

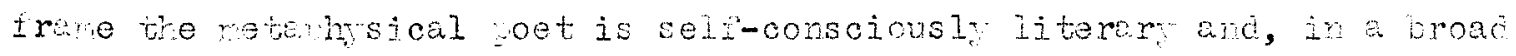

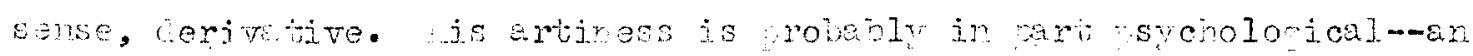
escepe from moderm life. It is also a peronty in part sonial, reverine the coets cesire to justify his role in societ in anodin to tile tastes of a snecial intolloctual clique. The retarnysical noet is no longer at 


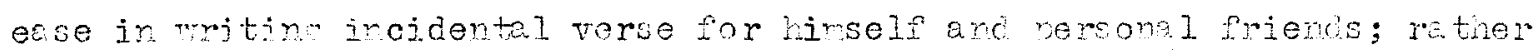

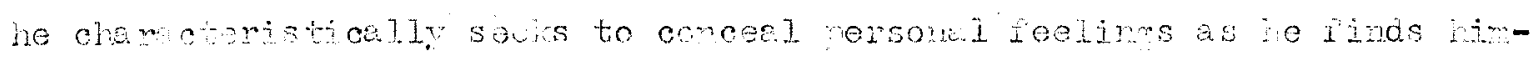
self retier neted ir the public eve as a self-conscions condentator or the uriness of nocerri life.

mis Ijorary reciousess trical of a reat ceal of rodem meta-

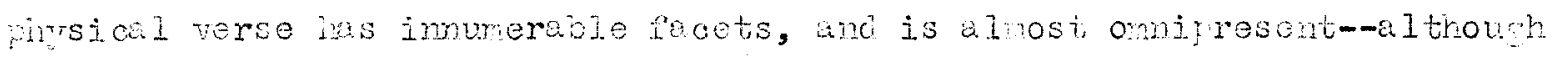

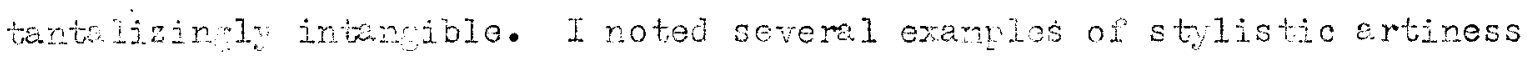

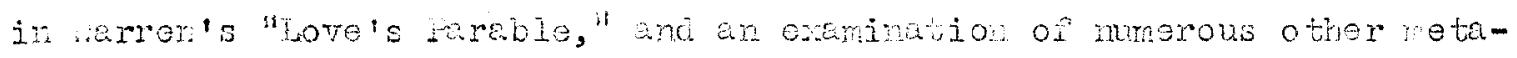

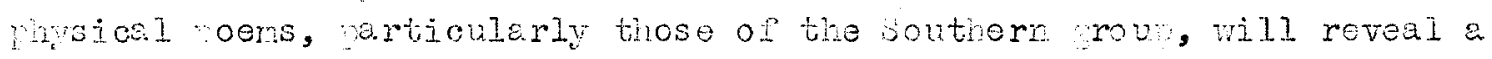
similor ary gualjte in theme, idion, hresing, natrics, exd a sophisticated, ton ne-in-ched viempoint. he rescer's fealin. that much contemporary verse boriers or the velletristic and ossesses a morked over" guelity is mobebly ane aidejly to "poetic tone," the subtre expression of tre joet's

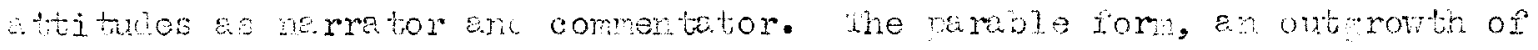
the oot's jncreasec self-consoionsmess and sociel-consojousness, is elso

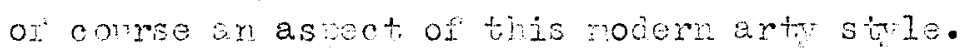

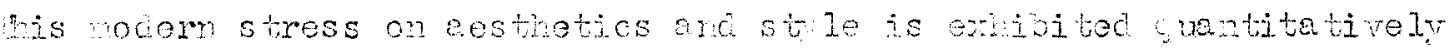

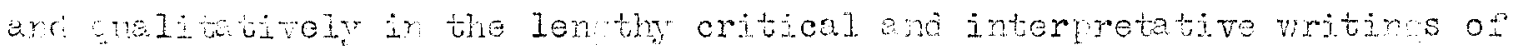

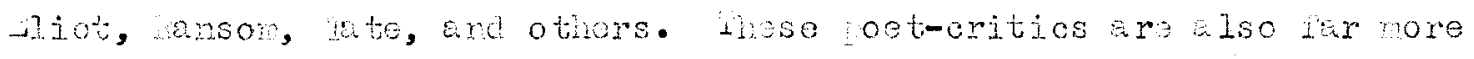
interested tian jonre in the rejation of their wort to the tracition an

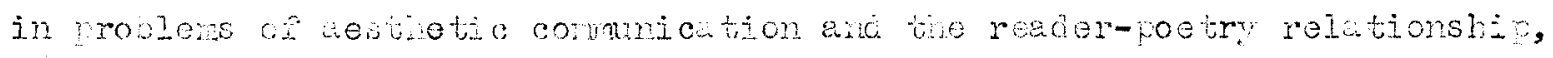

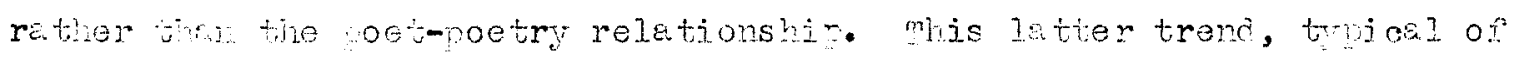

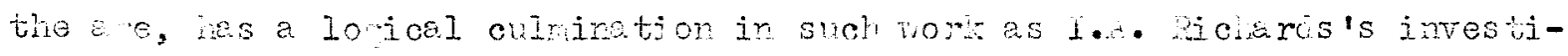
ratior ot in ma-menral imalses in his aestetic studies.

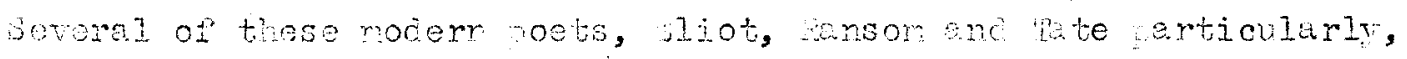

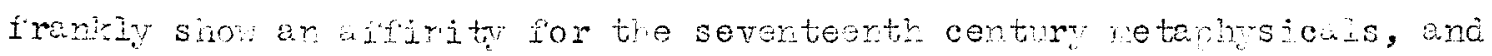

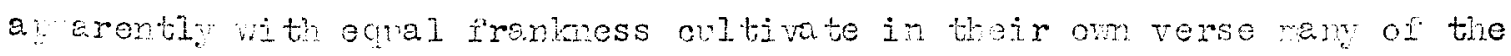
nost rentod soventeenth contury oetio virtuss, suck as tire jold extenced retanhor and the dothine of esstreotion in conorete jmener. jiot, for 
instance, discusses the exellences of tre erly retaphyscals in

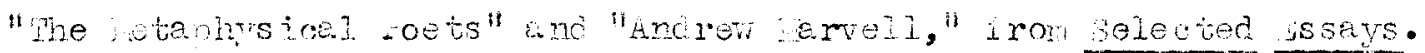
ansom, in "loetre is ote in ontolon" spalc of tree diferent

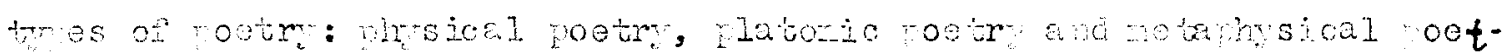

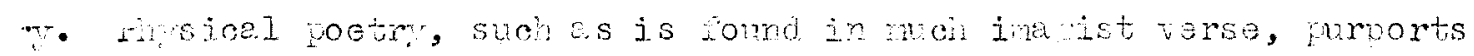
to prosut tins sn their thin iness, so to speak, wils pletonio verso

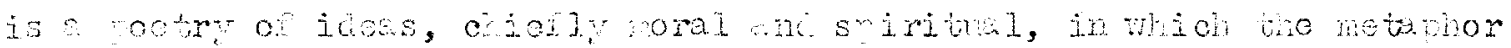

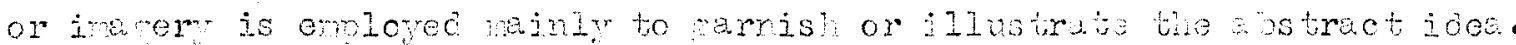

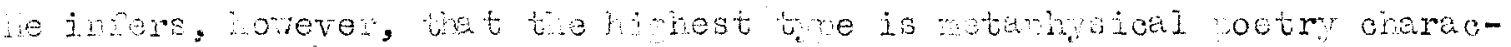

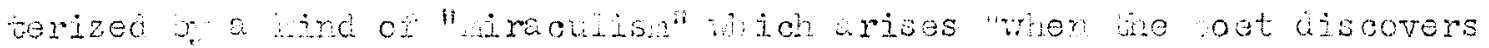
w. analo an icertify wetweon owjects wich is artial, thouph it shouid ve considerable, and rocees to an identiacation wich is con-

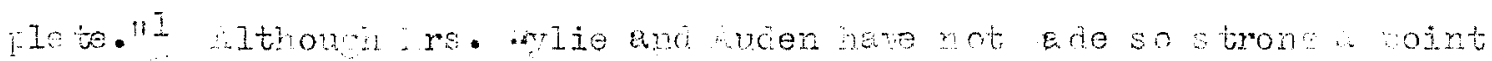
of risin the seventeenth centror tetanhicals, their varsa sucests

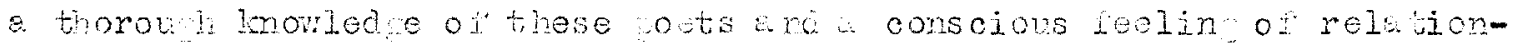
sine mith then.

"Dorivation" cha "inclvences," in e suriet senso, are diuficult to

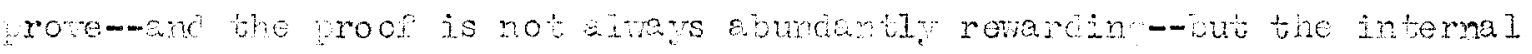

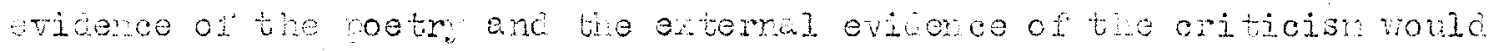

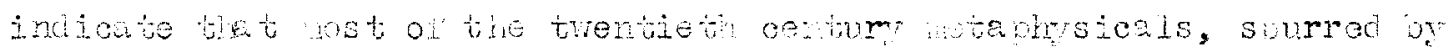
to reod and comlenities of this ere, have seli-consciously crived

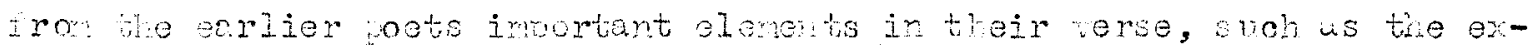

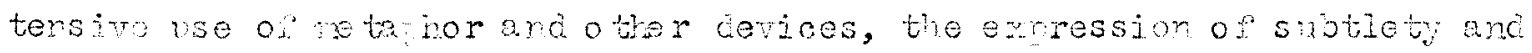
aistration in sensate inarew, and the complex treatment os experience.

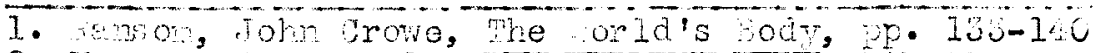

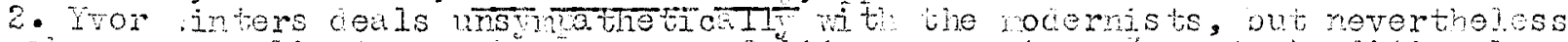
malus some salient $r$ ens aproros of "iterem cetry "sseucio-traditional or

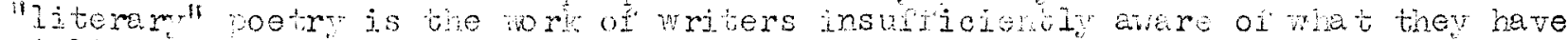
styistical1. and orally in com on with the best ootry o the race to naster

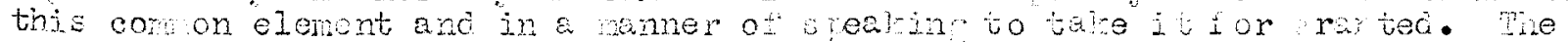

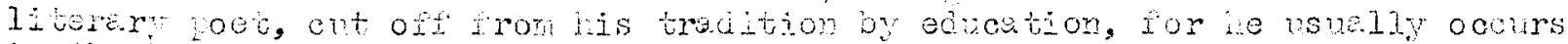

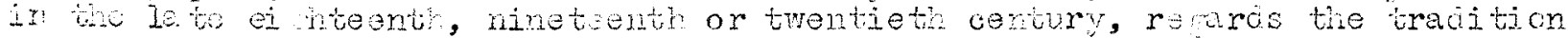

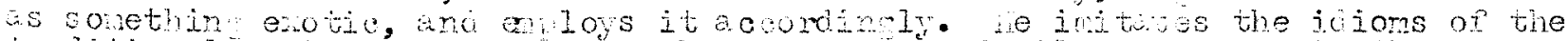
treditional joet, wt they are no Ioner or hin ferilise and exact; the are foresn and cocontive; the derenerate into manorismo" (-rimitivism anc Decacese, 75 
I here examined seventeenth and twentieth century netarhysical verse in the Ii wht of a Ioncal-incividul and e lsycholodeal-social irame. Who

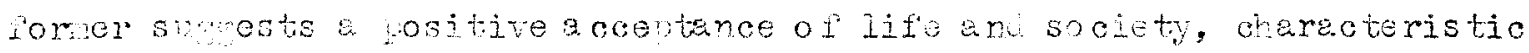

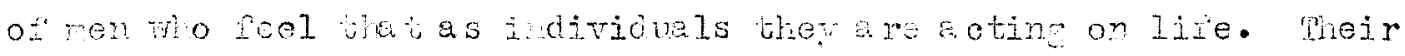
a. roech is, in a broan senee, lo id and ireot, for looic is their chacteristie tool and rean ir thingin and ectin ir lise situations.

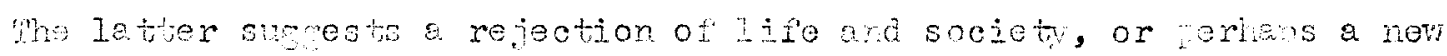
rode of s. cholo-icel adeptation, troical of men who feel whot they are

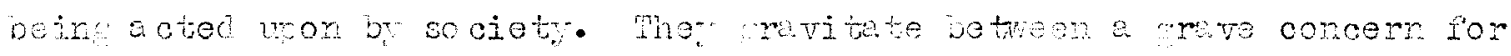
socjal oonditions ard a osycholorical escadst.

In the soverteenth centur we netarical roet is dienty concerned

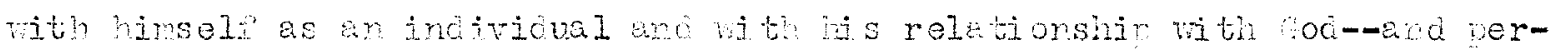
ians lso his mistross. He redizes tiot were are certain social evils, but wos not reel tet societ is enorocind upon and ruing is private

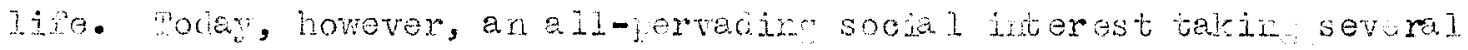
forms is one of the most in ortent featurs of nocm wetarinsicel verse. whe odem retawhical noet is far no concemed about his relationship

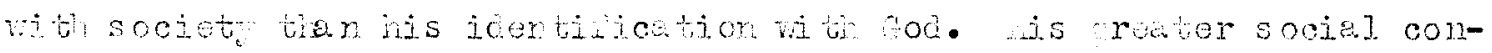
sciousess is cemonstreted in severel mes: in a subtion, noro conler procention of mman relationsips; in a vivid and ersistent portrayal of the social inact on private lives; in a cenonence on syoholorical

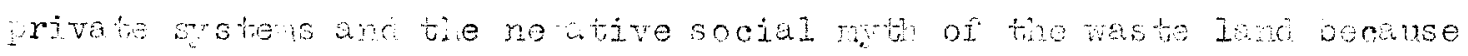

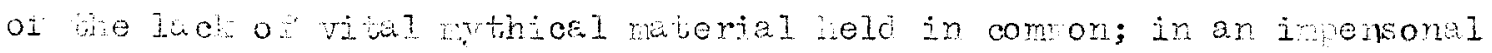

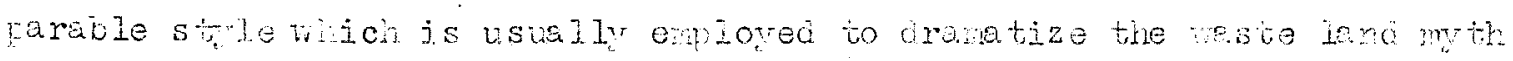
ir tems of the or smolic chareoters, witi the oet acting as merrator, and a literary, corivative style waich sumests the poet's desire to lind simificant older som apromiate to the are. 
CHAPTER VI

CONCLUSIONS 


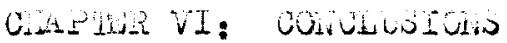

The question naturally arjses es to my seventoenti century pootic fom and experiential structures carr such a rotent arpeal for literaryminced nociems.

This tweitiet century interest in the serontedu century is aparent$1 y$ due in pert st least to similarities found in the two ceriods. If we

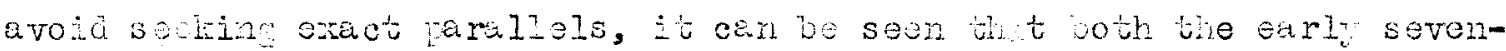
toanti and early twentieth centuries occhp simiar nositions as transitida? exs in the strean of istory an bot the intellectual clinates of tine two periods are comparable. Glancing back over recant ungish Iitorar. history, we see that the early years of woth centuries rere

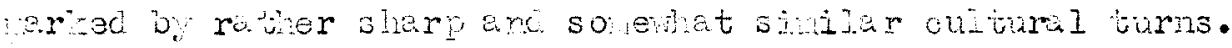

Whe serly seventeent century was signficant for sngish goetry because of the trangition from roknte jlinabotan (or Inelis. Remaissnce) stie to he netaphricel stuaro (or what ight with reservations be chlled the ingish beroque) styie. on a isterm level the early trontioth century was characterized by a revolteganst the romutic Victorian stu and the appearaco of the etaphsicel style, a wong interest th the lenaissance and a rising enthusas for the soventeath century An ipersonal juaustrial econom ana a scientilic e phasis vecane coninant social factors as religious anc porsonal values crmbler and individuls tencied do retire into private worlds.

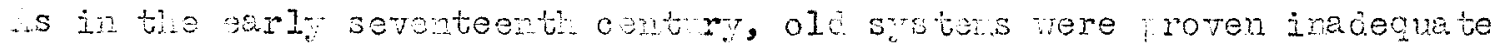
and living jocke increasing lore compar.

The Lenassance abounced in jouthrul exhberarce, romintio love, sweet pastoral lyricism, and so otimes sectwoular characters awidst violent tragedy. In the early geronteonth ontum infish verse tended 
to lose sone of its tenaissance de lance and lovitness as those vere

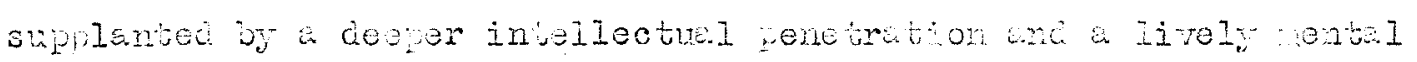

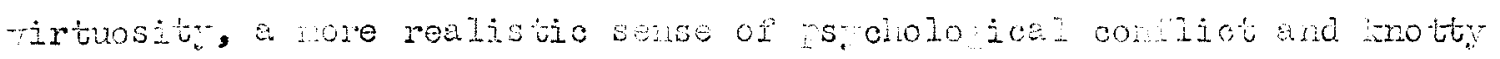

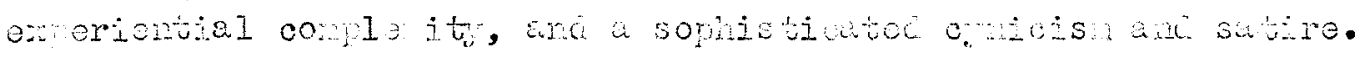

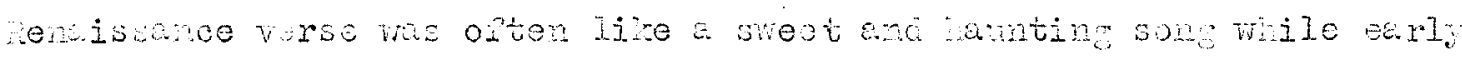

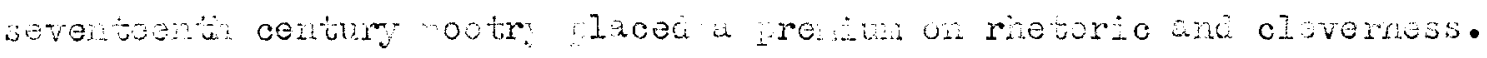

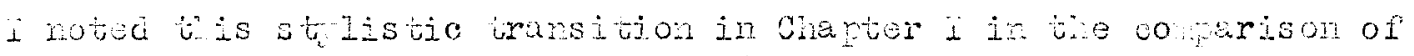

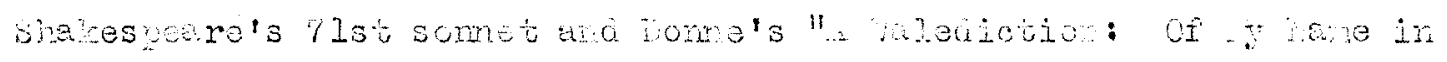
the vintow."

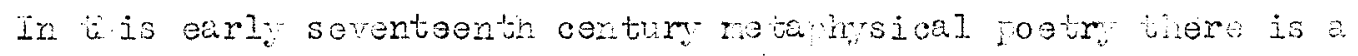

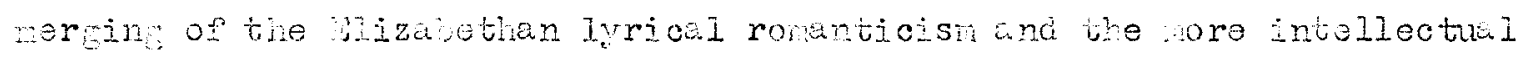

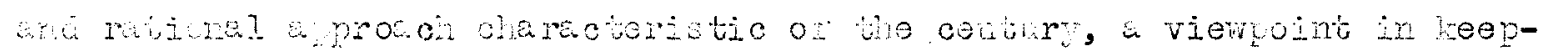

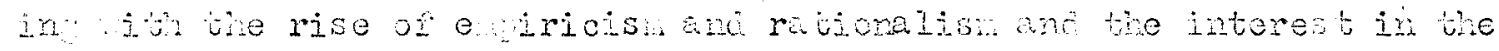

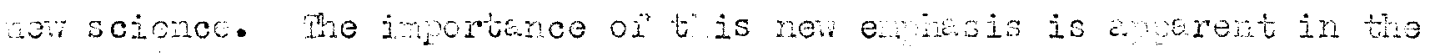

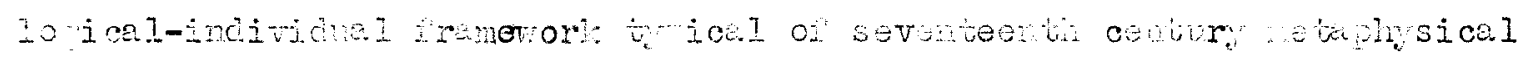

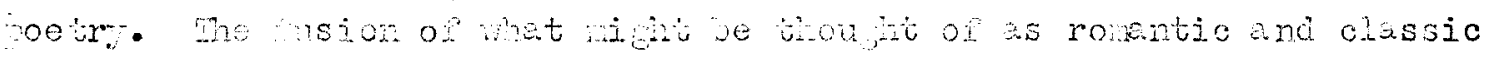

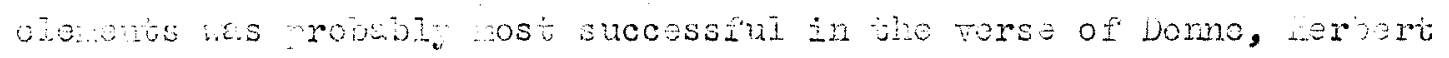

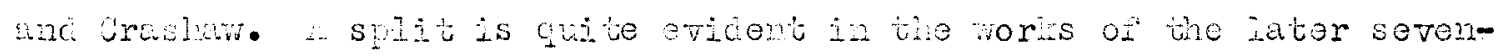

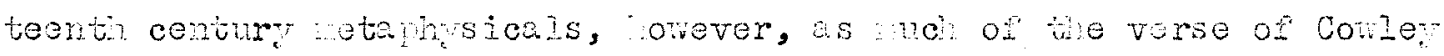
and amell articinates late severteenth and ointembin contur neoclosicis thile the verso of vaghin and haluene contains rowatic

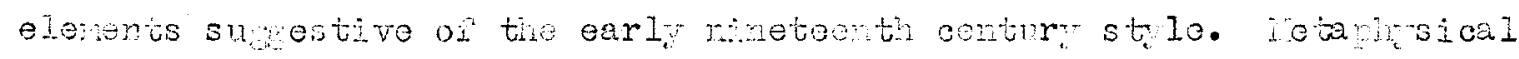

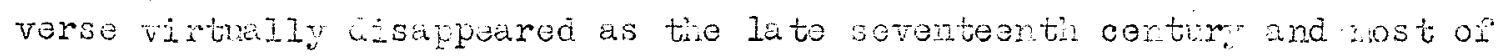

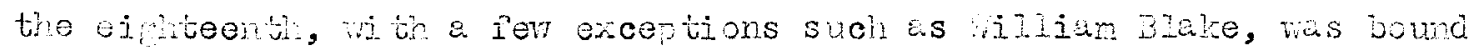
by a delir rigid reo-classicisme

the early ninet enth century inaurated a pordod of romenticism

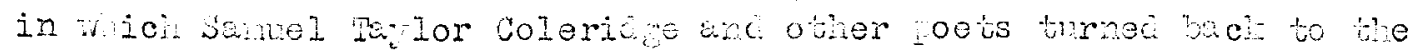


sweet nusic and sujoctive Irricisn of the mgish reneissance with an

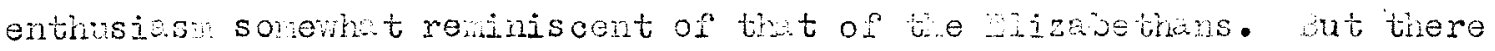
was an importat difference, lowever, in that nuch of the romantic verse

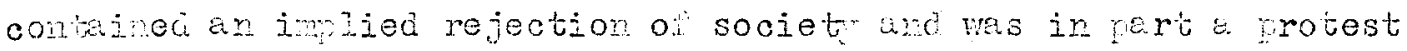
ardist ine encroachent of a odern, juporenal judustrial society and

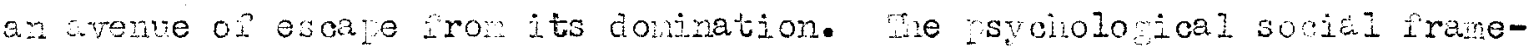

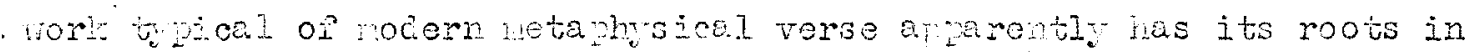

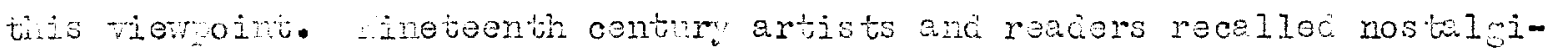
caly the hearty ror and le licate groe of the leneissunce, ancin an ase or higly prized, but dininising individualisn looked back with garticular fascination on the sweet I rio prace of lenissance rerse and the i hty charaters that stalked through sizabothan drama.

The trensibion in noisn verse marad by the wanke of the uineteenti century ronentio sty and the rise of tho twentieti century metaphysical style showed a significant similarity to the earlier transition fror the sizteenti to the seventeenth century there was a trend whe from the contemlative sweetness and sentinent of the rineteenth centuy tomer a more sympthetjc feeline for the comlexj ty of experience, an increasec accent on prinarily intellectual elenonts, and en attitude oi sorkisticatod disitusionent. Lwentiet century literam erours, like those of the seventeerth, a parently tere plessure in the enotionalintellectal justerition and in the concrete sensateness and intellectual

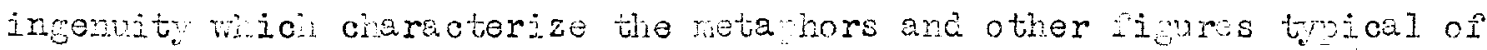
notansical verse. as with the nineteenth centry antint for the enaisconce, it must e remeniber that the fwentie di centum literarymincied, essentially unlike those of the seventeentl century, tene to ro-

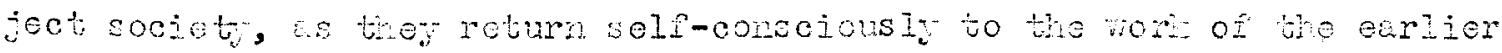
neta hoids and vite in stole that is at least in sore reasure derivitive. The nineteent-brentioth centry transition, hovever, is in 


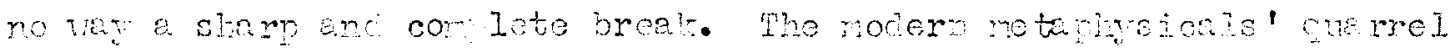

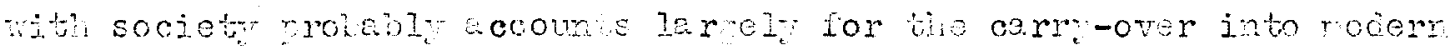

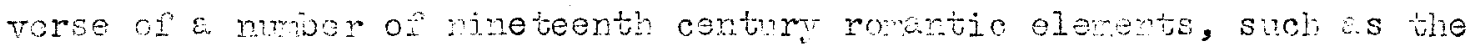

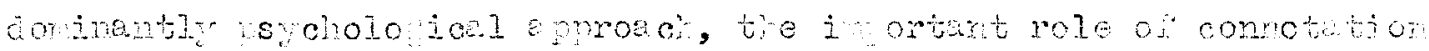
an sujectism, anc the ironic contemiabion of e erience. I noted

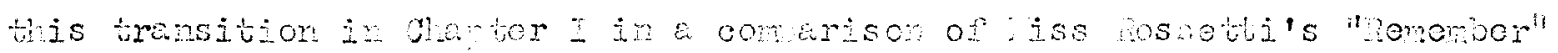
and Yeets's "uroken Dreams."

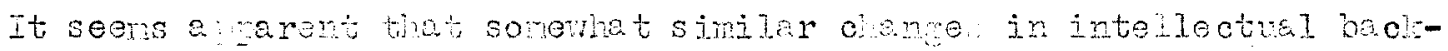

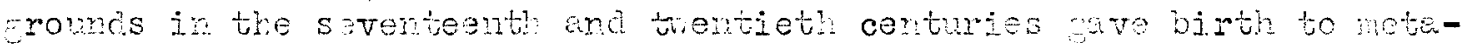

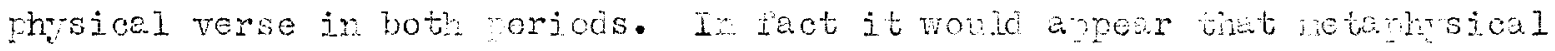
poetre, rercine losical abstruction and concrote inegery vith an expession of cen jersonel feoline and subta states of ind, is a procuct of or or yon sowere jone between fil-jom claseicisu end romati-

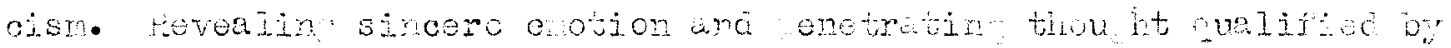

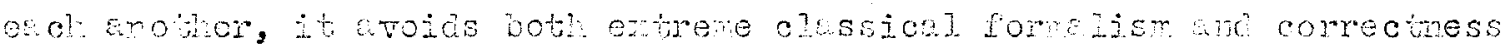

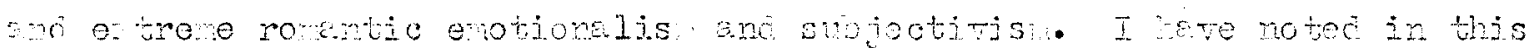
cometion thet the breation of the netewheical tration in the iate

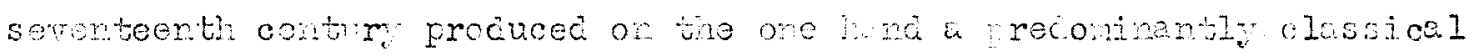

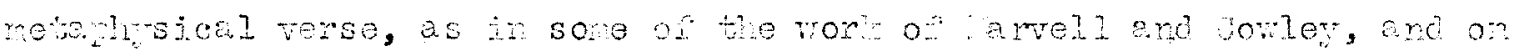

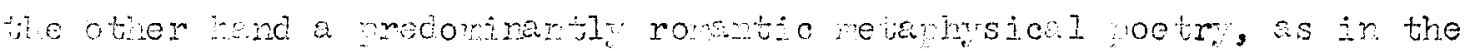

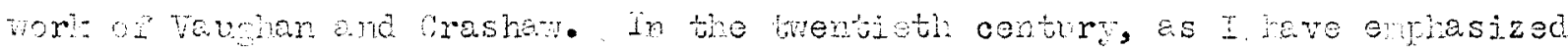

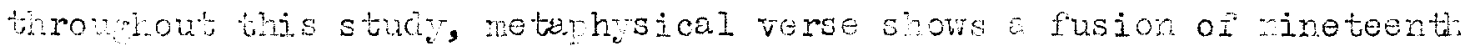
century romaric clewents uith seventeentr contury forms, cerices enc treabunts of exporionee.

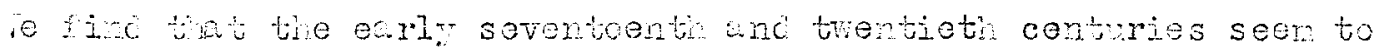
nay roblor wiliar roles in the arom of istory. wht, then, are the 


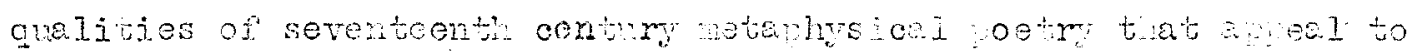
trentieti contur wocers, wh wat are bo ring cifferences of approat in the tro eras?

It is on course diplont to analue ver setistactoril the social

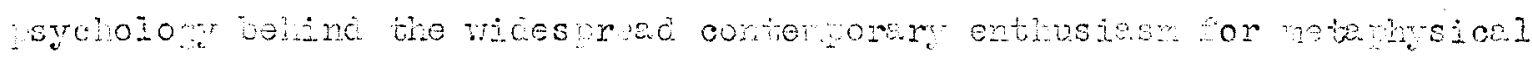

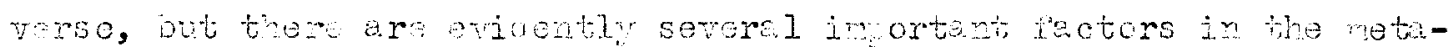

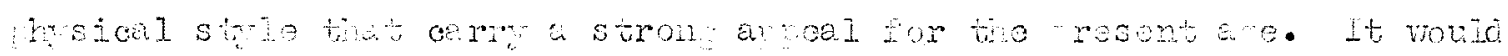

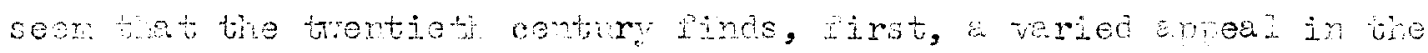

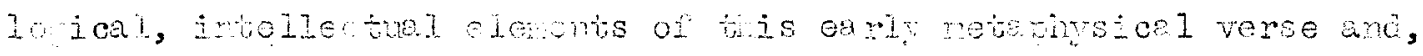

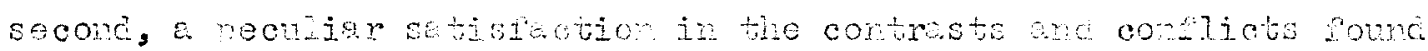
in jos cotic joms anc eneriential structures.

It seoms rosible, por inotenoe, that tho ciract, assetialiy

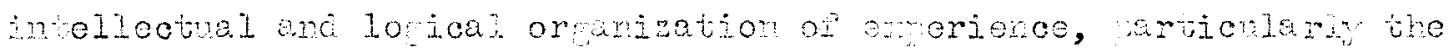
us of the extanci nobenor, al ords a sene of stobility, unity and

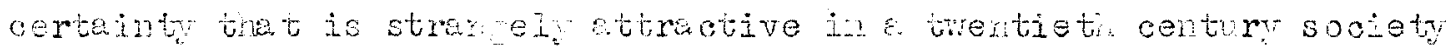
Wich seens so full of flur and uncerainty etavor, particklarir,

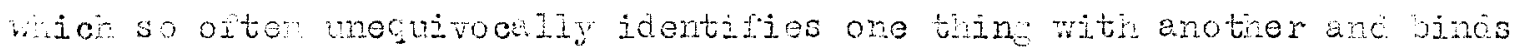

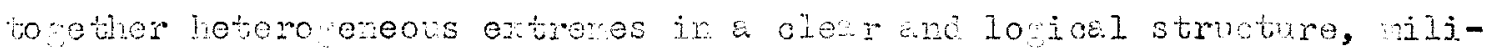

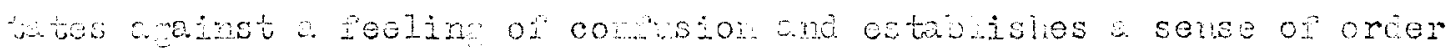

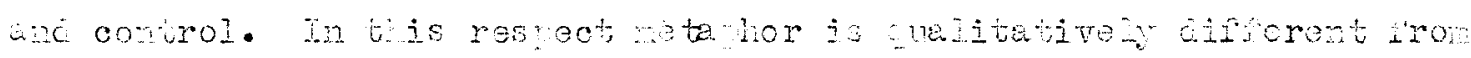

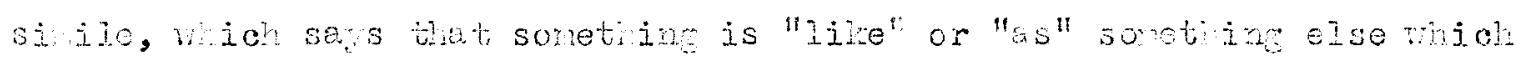

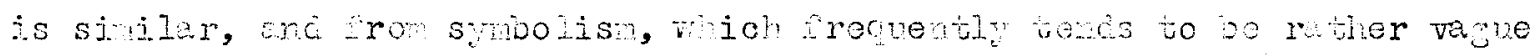

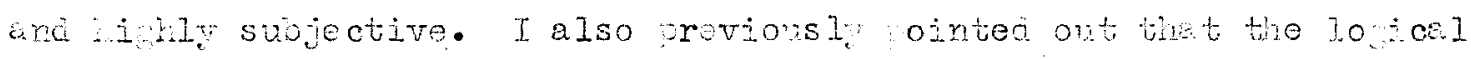

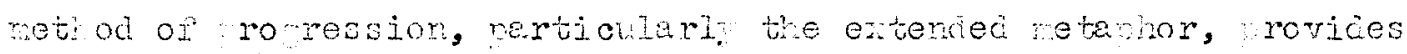
an orciered and controlied revework to wich the oet car comit in emerience directid, seeking an exinction of emotion. Mile tho trentieth century aporoach is of course diterent fore sycholo ical than Inscalj, the pdem noot are peder quite ossible find that the in-

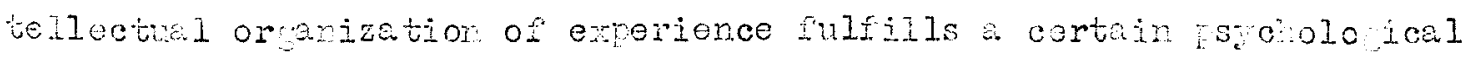


need in an a e mred $b$ uncertainty and stevens's uniciding "prossure

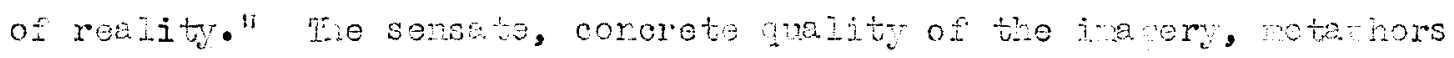

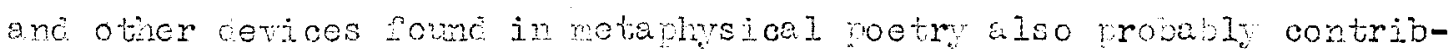

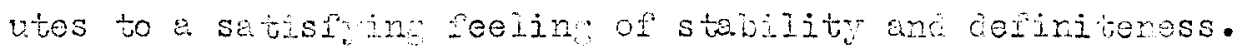

In adition netanrsical veroe ras an intelloctal aper wich

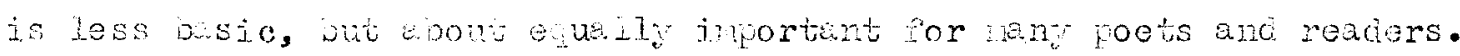
This ampea is seen in its enphasis on intellectud virtuoity, montal Mrnatics for tieir om sale, as dismlated in the a t and in enjous

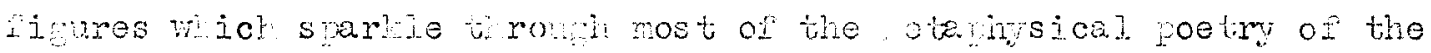
sevonteenth anc twentiet centuries. The trenteth centur, charecterized Ir man war by nervous strivin apter novel and voritu, ofter de-

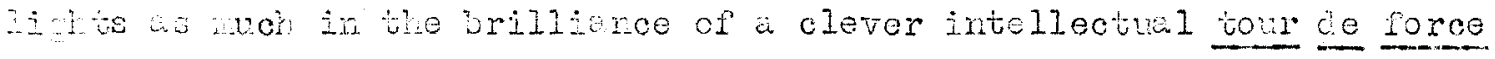
as in the doener toundatiors of oetry -erhans the rost funcanental recion for the opulaty of weta-

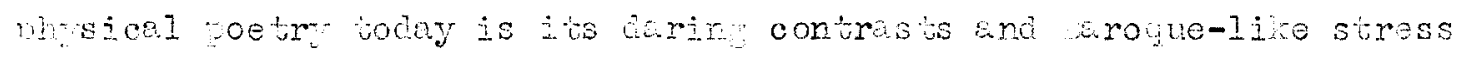

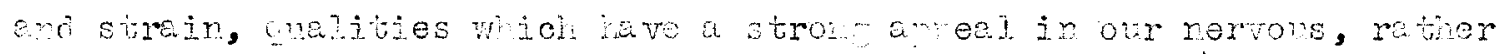

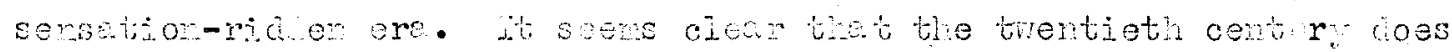

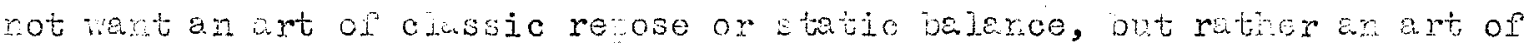

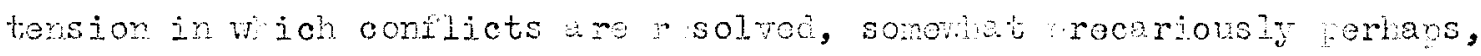

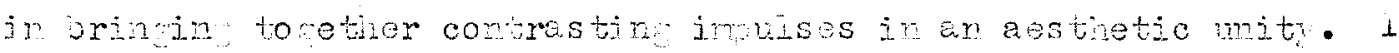

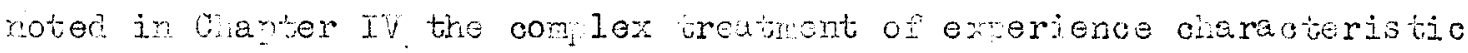
of meteihsical verse end the inportace of such elecents es vit and irom,

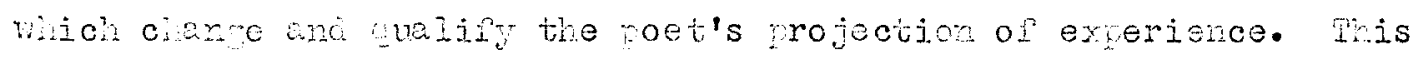
bentor, strilar to the senoe of stres and strein found in the con-

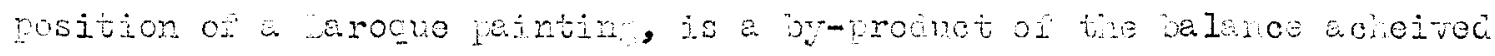
In mon metaphsical pootry betreen the invellectual an onotionel, the roratic and the classic. L ljice anoel is roobly found in otier

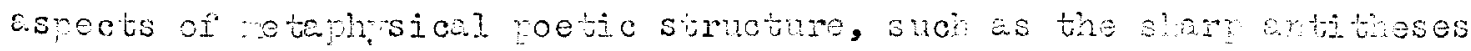


ani the bolo contusts al the tenor anc renicle of eneterhor.

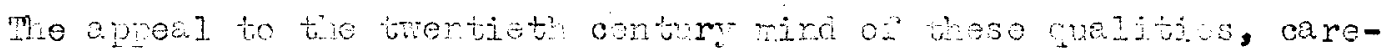

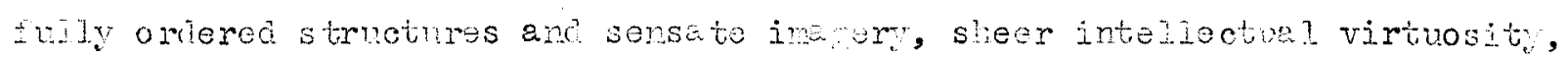

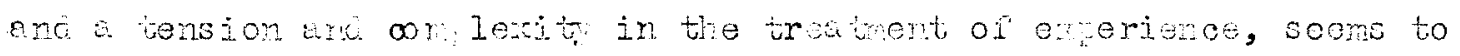

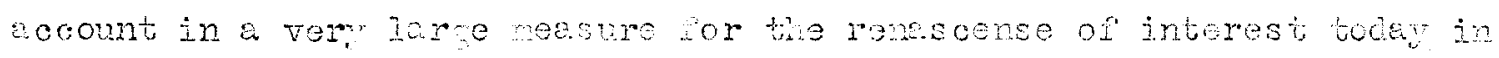

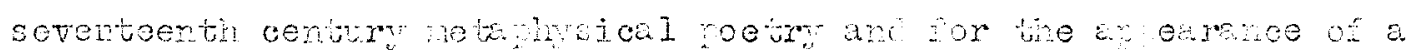

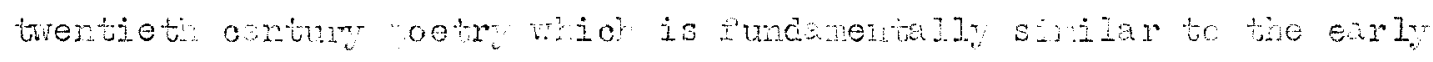

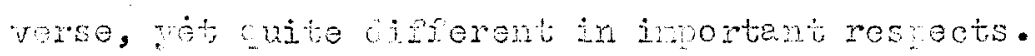

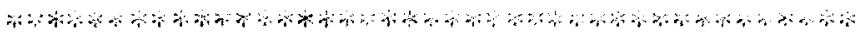

The diforences between tho sove seenth and twentieth certury aproaches aro of conrse both shiblo an involvec, but lave angu

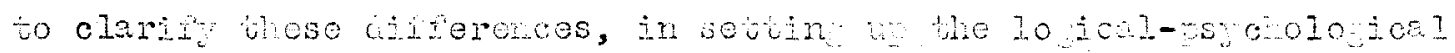

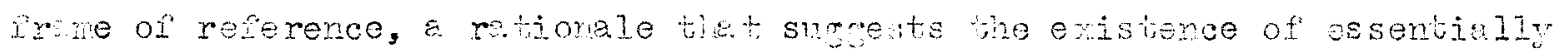
aperent atjudes toward lije and societ in the two eriocis uncer disoussion.

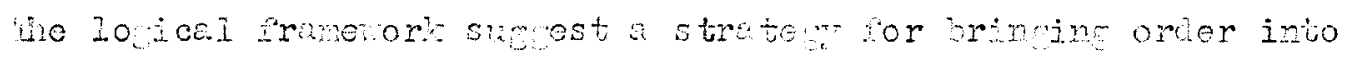

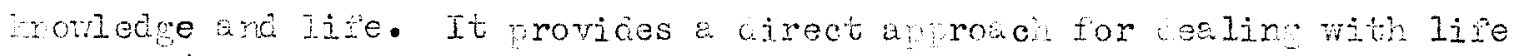
anc controllin it, and imaicetes a ositive, conidew thitude oz

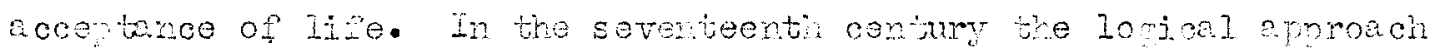

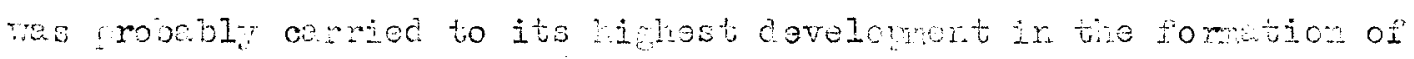

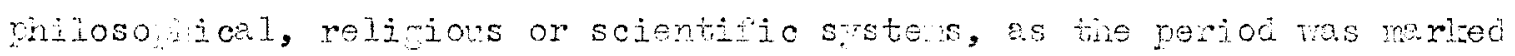

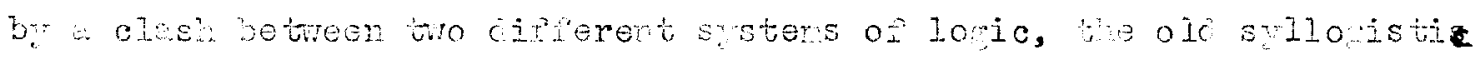
abstrections of the schoolmen wh the new empricisina rebio aljsu of ue fomarc-loobin scientists, mathoticians ond hilosolers. bm-

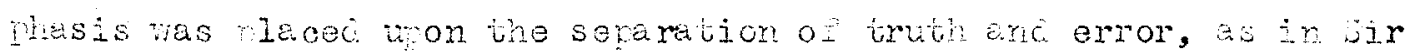
Traucis acon's ciscussion of tie "icols" in ovur ranm and ir Inomas

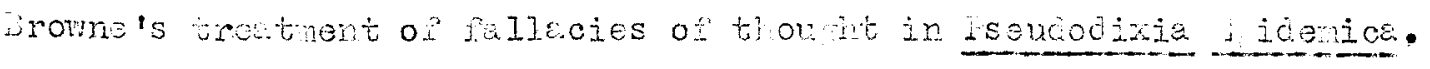


Truth ani nowled e vere looked von as having an existence externel to the mind of men in very ruch the sone war as the lowical methor of potic rogrosion functioned as an exneriential fromeworl mich seoned extengl to tre ind.

The wentieti century psychological raticnale provices a stratery

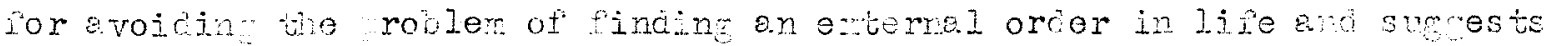

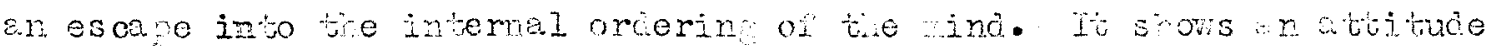
of enotional adjustent to lize, a ino os accentence tramcencin a

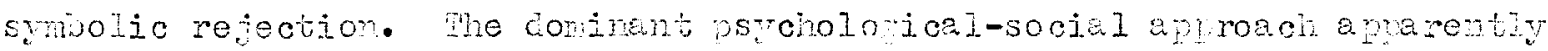
rows out of contomoner soojo-3conomit contiliots.

Like the robum to olcer, nore orvered wetibsical ioris, bie new

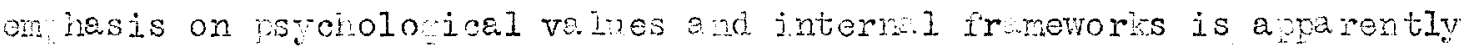

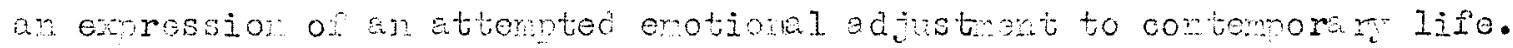

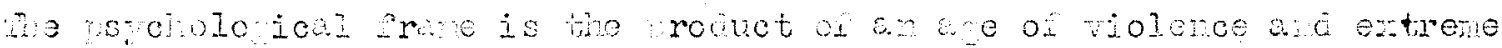

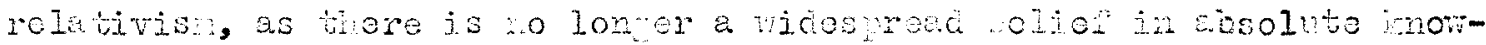

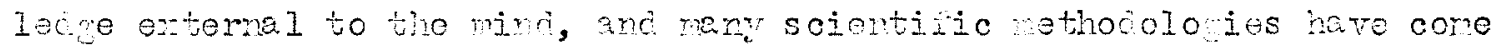
to be looked upon as convenient irmotheses.

Wile the losical mamevort tomec to de static, rotionel and

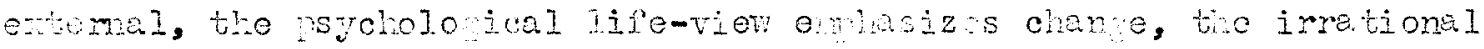

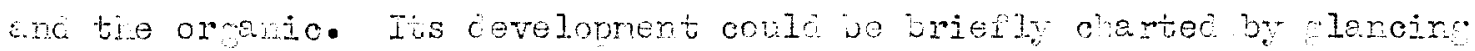

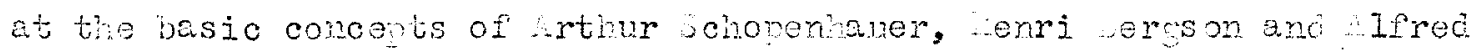
orth nitehead. Schopenhaver, for exaryle, with his conogt of wirvana, or the "world es icea," of the uncessne imetional force of the aill,

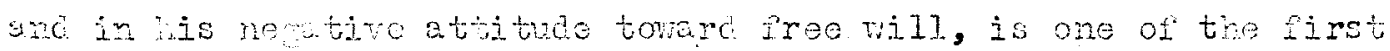
rinosolucel represo tatives of the modern s. dolo ical aproach. serson, presontin the concet of an elen titel wlich can at loast clat

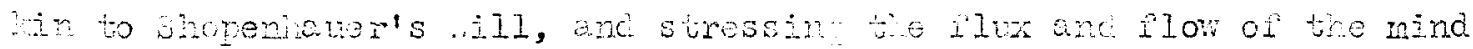

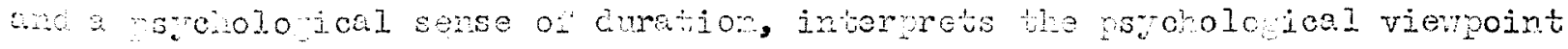


in tems sonewat nore complete and wore conenial to the nodern era. It is also important to renemoer the essentidir human and sychological character of ditehead's emphasis on omenjsm, process, prehension and Q.ecic Dipolarjt.

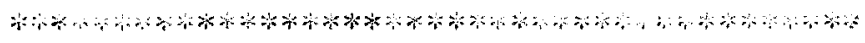

Two important and closely reiated problems aro ret to ve investigated. There is, pirst, the vestion of wat eloments in the intellectual cnd socio-economic bacromis of bie early seventeenth and wentieth centuries cave birts to netahsical petm, and there is the comenion avestion of what are the relatjonsilps between metephysical verse and other art forms. It is robable that selind bie complexity of seventeenth century and

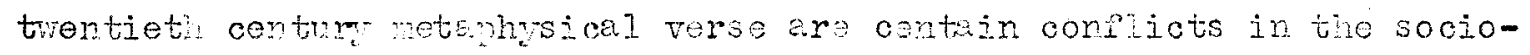
econonic and intollectral backrounds and that the neture of these conlicts ielps to accunt for the 10 ical anc poycholonal arurouches evi-

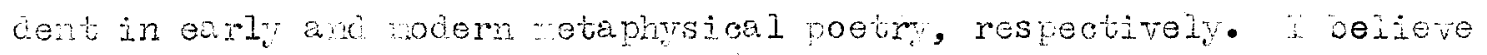
that in the severibenth centur the confict tenced to anper on what Alt be cajoc a coswic lovel in o clesh jetween the old christianwholastio vier of life and the now scientio vion, dic it is possole to thins oi the conflot as symbolized in the inteliectuel a gitation censed br tho copernicsn teom, as disniared, for instarce, in Dome's "Whe matong of the corlde" the approach to his cosnic confict was chicly on a lowical level as men sont to zeret out and iscarcerror and fellegr and to lay hold ox asolute verities external to the nind. I jelieve thet in tire trentjeth century the conizict is on a social level, as ambists and nen cener.1. Iy sem to reel that tho a peces a crisis in rantanine vital iife values aginst the increasin pressure of an imorsonel mechanical civilization. s essertiall psycholo ical approach 
was necessar in dealin; with this provien, a conjict wioh can in no

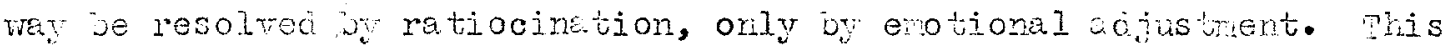

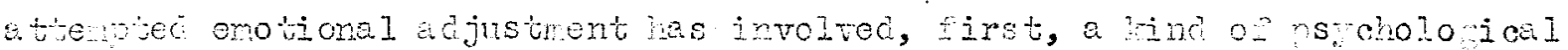

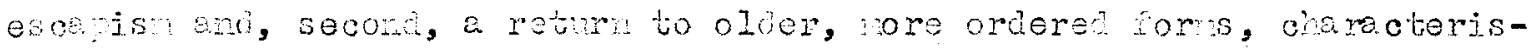

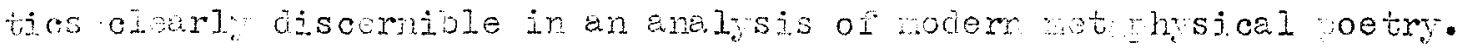
me somewat no:e jott second roben concoma the relation of

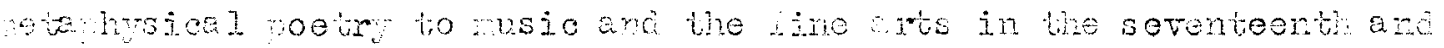
twentiot centuries. in doslin with such a problen it is ichly irm-

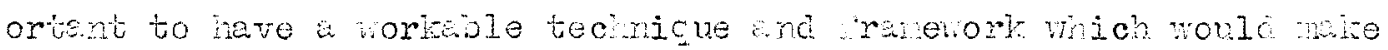
possible an ojective commison of difenert art fomo ws the derelogwent of such an sntront of reference is verond the scope of this study, I can only mere a cew rutier subjective sug,estions. Where are, for exExple, the a perenty simiticant relationshin betweer seventeent certur motephical ntaphors and the tine arts emblens, as noted by praz, and a lind of wetanhysal comlexity in many of the serio-conic religious etchings of dembrand. In modern art tho social roblem is treated in a mober of omressions of the imagnetive-industrial rolarity, wile both

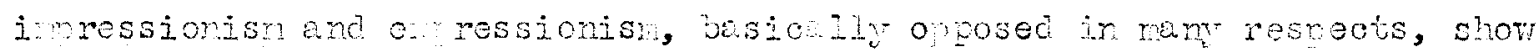

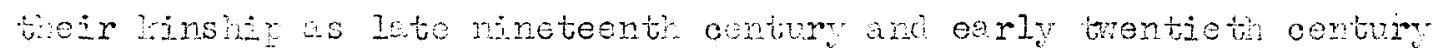

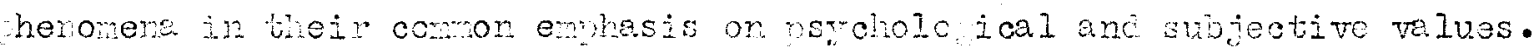

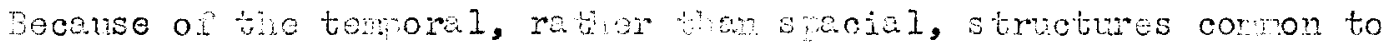
both oem ane nusic, stristic and structural comarisons of tiose two ort forns are oten rore rewarin than similar comarisons of potri and íbe ars. I believe a defirite relation can be treced, for instance, wetween the eleboratei. Io icel orogresion characturisic of severteenth century netephical. verse and the compicateo contraputal baroque-like structures of Ingish anc Continowtal music in the seventeont century. Like the potm, the nusio of the past severai coceos stows an essentially 
nswcinolowical proression, as the nore rididoms have been ubarcioned for so-celled atoneliby, tonal color and tarioty ruther than melody.

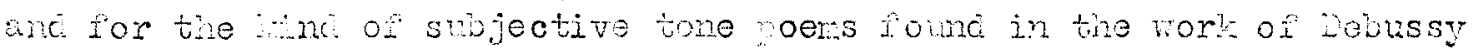
and otiers. Ls in verse, stross is laced or mood and connotation rather than won themato construction. Whe relationship seers perticularly cleer between renol smooljst verse, revoh impressionist musio, and Trench impresionist pintin. Con ositions of Cosar iranch and Lax eger iso fpear to cenenc upon a juture of olcier lo jeal and modern psicholo ical elemerts similer to that found in twentieth century metaphysicel. verse.

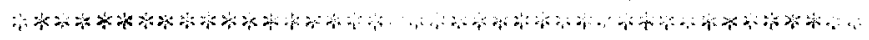

In this study i lave tried to present analyses tist were close and objectite and st we sace time to employ concopts with were brosd enoum to suport helpful aneralizations. Thelieve bis arer has unswered bive imedite auostions conceming the sinjler and cisi jier chrecterisbics of moterhsical vere in the sevanteenth anc trentiet centuries, wh 2 here never looked vpon this analrsis as an and in itselp. I sincerely hore thet this sbuly war servo an heuristic function in pro-

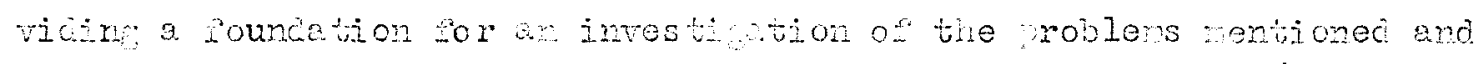

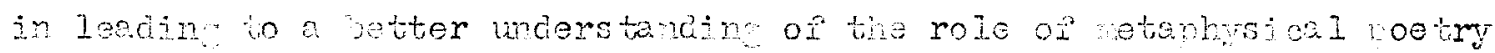
s.r. Gle exry sevontenti anc trentjeth centuries. 


\section{BDHIOQWAT}

Dotry

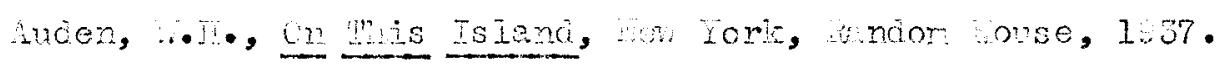

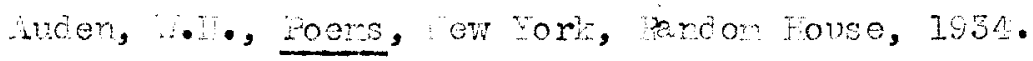

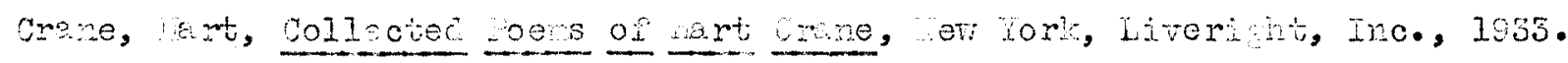

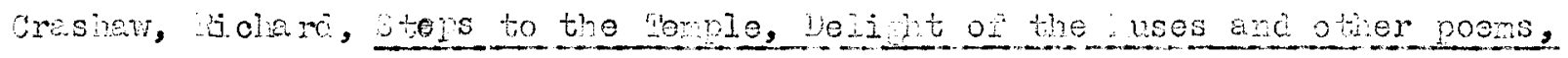

Camorica geiversity Gross, 1904 .

Dome, Jom, Whe gonlete ootri and glected rose of John onne and the

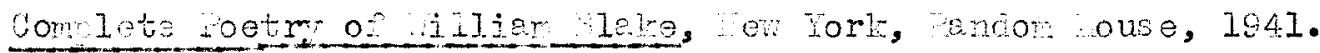

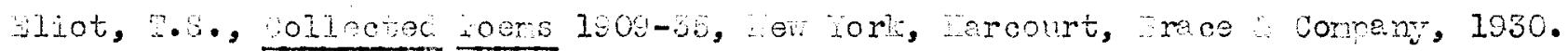

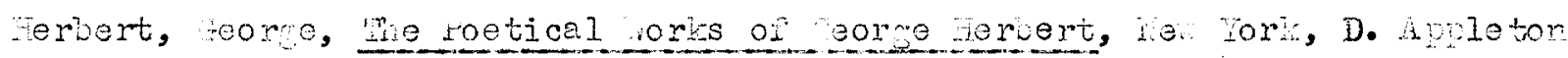
anc conony, 1857 .

jeforve, Julas, ceurres competes, taris, jociéts ce hercure de rarce, 1003. iarroll, whirew, oons and Letwens of ndrew arvell, volwe I, oxiord,

Cinreadon rioss, 1927 .

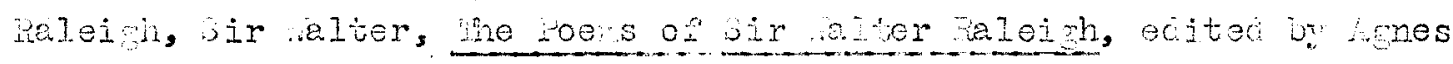

Lathem, oston, courton iffin compan, 1928 .

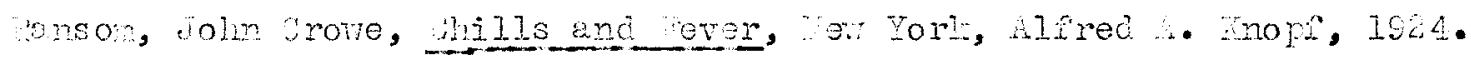

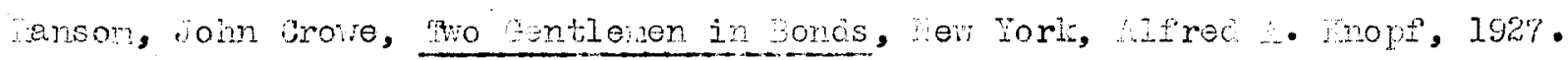

Tate, Wlen, selected toens, er York, U. Scribner's sons, 1967.

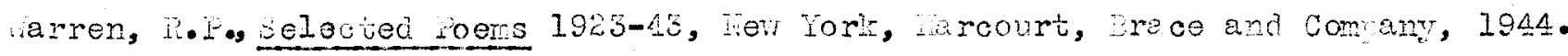

Blie, Jlinor, Gollected Poers of Iiror ylie, iew York, Alfred 2 Tnopf, 1942.

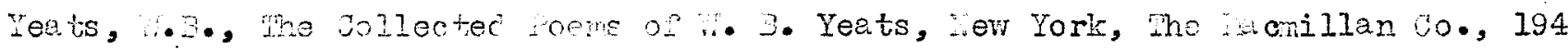

Gribical horks:

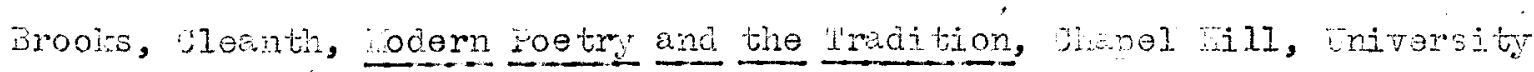
of Lorth jarolina zress, 1938 . 


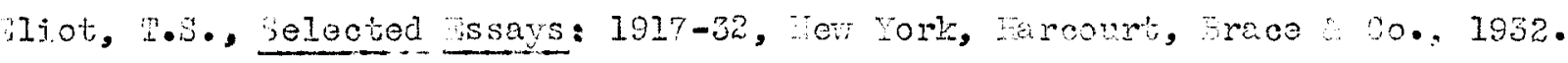

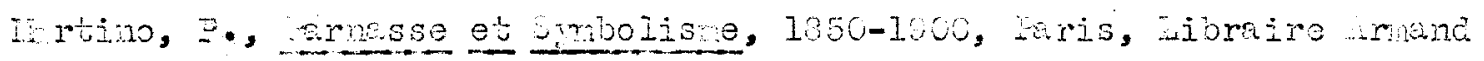
Colin, 1935 .

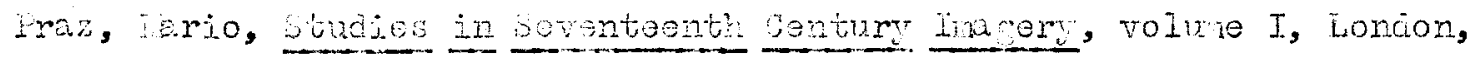
.arour institute, 1930 .

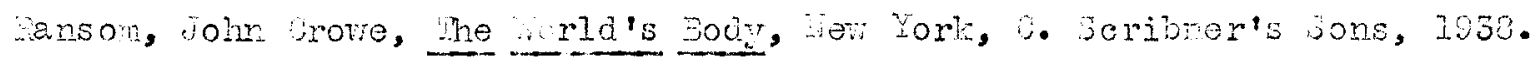

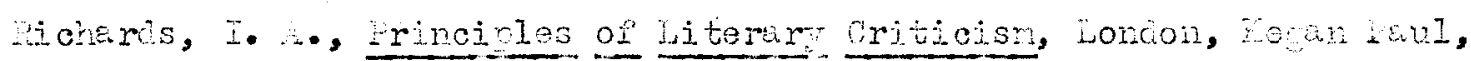
Trenci, iruoner ane comang, 1826.

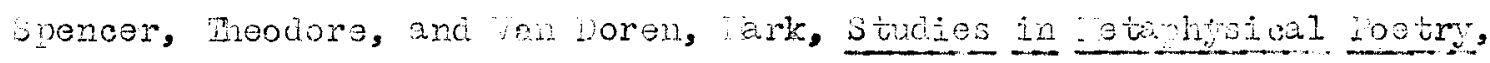

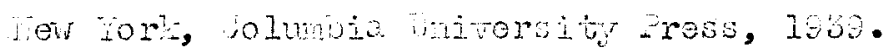
btovens, allace, "The roble rider and the sound of corts," in the

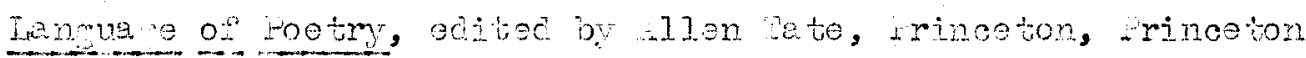
Triverist frass, 1922 .

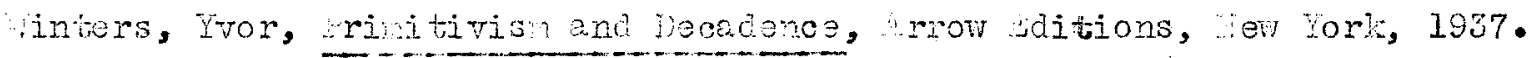
incyclopecia:

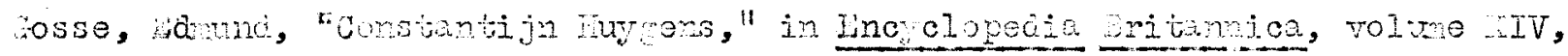
Comoridge, Giversity zess, 1010 . 